\title{
A magmatic trigger for the Paleocene-Eocene Thermal Maximum?
}

\author{
By \\ Andrea Rose Dubin \\ B.S., California Institute of Technology, 2009 \\ Submitted in partial fulfillment of the requirements for the degree of \\ Doctor of Philosophy \\ at the \\ MASSACHUSETTS INSTITUTE OF TECHNOLOGY \\ and the \\ WOODS HOLE OCEANOGRAPHIC INSTITUTION
}

June 2015

(C) 2015 Andrea Rose Dubin

All rights reserved

The author hereby grants to MIT and WHOI permission to reproduce and to distribute publicly paper and electronic copies of this thesis document in whole or in part in any medium now known or hereafter created.

Author

Department of Earth, Atmospheric, and Planetary Sciences, MIT and Department of Marine Chemistry and Geochemistry, WHOI

May 21, 2015

Certified by

Bernhard Peucker-Ehrenbrink

Thesis Supervisor

Accepted by

Elizabeth B. Kujawinski

Chair, Joint Committee for Chemical Oceanography 


\title{
A magmatic trigger for the Paleocene-Eocene Thermal Maximum?
}

\author{
By \\ Andrea Rose Dubin \\ Submitted to the Department of Marine Chemistry and Geochemistry, \\ MIT/WHOI Joint Program in Oceanography/Applied Ocean Science and \\ Engineering on May 21, 2015 in partial fulfillment of the requirements \\ for the degree of Doctor of Philosophy
}

\begin{abstract}
Fifty-six million years ago Earth experienced rapid global warming $\left(\sim 6^{\circ} \mathrm{C}\right)$ that was caused by the release of large amounts of carbon into the ocean-atmosphere system. This Paleocene-Eocene Thermal Maximum (PETM) is often cited as an analogue of anthropogenic climate change. Many trigger mechanisms for the carbon release at the PETM have been proposed. Common to all scenarios is rapid release of isotopically light carbon $\left(<{ }^{13} \mathrm{C} /{ }^{12} \mathrm{C}\right.$ values $)$ from methane hydrates, terrestrial or marine organic matter, as indicated by a pronounced excursion to light carbon isotope values across the PETM. I test the hypothesis that the PETM warming and isotope excursion were caused by the intrusion of a magmatic sill complex into organic-rich sediments in the North Atlantic. The intrusion of magma into sedimentary rocks will cause heating and metamorphic reactions in a thermal aureole around the intrusion. If these sediments are rich in organic matter, large volumes of isotopically light carbon are rapidly released. I examine geochemical evidence from lead, osmium, and organic carbon to place constraints on the extent the carbon isotope excursion during the PETM may have been caused by contact metamorphism of organic-rich sediments. Potential terrestrial and submarine analogs are examined to determine the behavior of these elements during thermal alteration. Furthermore, geochemical evidence from sediment cores at the PETM provides additional information about what might have caused the carbon isotope excursion. I find that lead is not a suitable proxy for carbon mobilization to the overlying seawater during contact metamorphism. Osmium, however, is mobilized together with carbon. Making reasonable assumptions for the ${ }^{187} \mathrm{Os} /{ }^{188} \mathrm{Os}$ of the sediments from the North Atlantic Magmatic Province (NAMP), constrained by the ${ }^{187} \mathrm{Re} /{ }^{188} \mathrm{Os}$ of organic-rich sediments and the depositional age of the sediment, the entire marine osmium isotope anomaly at the PETM could be explained without the need to invoke enhanced continental weathering. Based on estimates of the extent of mobilization of organic carbon relative to osmium, approximately $47 \%$ to $60 \%$ of the carbon released at the PETM may have been derived from thermal alteration of organic-rich sediments in the NAMP.
\end{abstract}

Thesis Supervisor:

Bernhard Peucker-Ehrenbrink

Senior Scientist, WHOI 


\section{ACKNOWLEDGEMENTS}

While this thesis may be submitted with my name, the number of people who contributed to my success is much larger. This thesis is a testament to the countless hours of support provided to me by my supervisors, colleagues, family, and friends. I would not have gotten through this process if it weren't for all their support.

First and foremost, I would like to thank my advisor, Bernhard Peucker-Ehrenbrink, for the guidance he has given me throughout this work. His patience allowed me to think through ideas and develop my skills as a scientist. His direction and insight helped guide my thinking and discover new ways of tackling difficult scientific problems. I am grateful to have learned from such a professional advisor who cares so much about his students and their development as scientists and researchers.

I thank the many collaborators I have worked with who have contributed to my research and development. David McGee has given me a tremendous amount of help, both by allowing me to work in his lab, saving a lot of travel time, as well as providing fresh perspectives on various data sets. Delia Oppo, Bill Curry, and Olivier Marchal, with whom I did my project for my general exam, were very helpful, not only in guiding my work, but in helping me adjust to the process of graduate education and research. Delia, especially, has provided much personal and professional advice throughout my tenure and has been an incredible advocate. I thank Delia Oppo, Jeff Seewald, and David McGee for their participation in my thesis committee and their thoughtful guidance and feedback throughout the process. I also thank Dan Lizarralde for serving as the chair of my thesis defense and providing a different perspective on some of my work.

I thank Ken Sims from the University of Wyoming for his help with identifying suitable rocks for my project and sampling in the Raton Basin. Greg Ravizza provided splits of the DSDP Site 549 that he previously measured for osmium, and Heather Stoll provided samples from ODP Site 690. I thank David Glover for his advise on statistical treatment of the nonnormally distributed data presented in chapter 2 . In addition, Tim Hesterberg provided me with advice on statistics, and specifically advice on the Bootstrapping method. Jerzy (Jurek) Blusztajn provided assistance with the NEPTUNE, and Gretchen Swarr was very helpful in assisting with getting Re data from the E2. I thank Tristan Horner, Jeremy Owens, and Tracey Conrad for their help with operating the High Pressure Asher. I also thank Margaret Sulanowska for her help with grinding the Raton Basin samples. I thank Carl Johnson who generated the organic carbon and nitrogen data at the WHOI Organic Geochemistry Facility. I am also thankful for the help of all the staff at the Gulf Coast Repository at Texas A\&M, who assisted me in obtaining samples of the Guaymas Basin. Finally, I thank Irit Tal for her assistance with analytical work in the McGee lab at MIT.

Many administrators, both at MIT and WHOI, have helped me both personally and professionally navigating this complex process of graduate school. Special thanks go to Julia Westwater, Meg Tivey, Mark Kurz, Ronni Schwartz, Ed Boyle, Mary Elliff, Sheila Clifford, Donna Mortimer, Mary Zawoysky, Blanche Statton, and Jason McKnight who have all provided critical support and advice.

The wonderful cadets and cadre of the Paul Revere Battalion have been incredibly supportive, not only of my academic pursuits, but of my personal and professional development. Their feedback and support have helped me grow and develop as a cadet, leader, and as a person. 
The communities I have lived in at Epsilon Theta and Ashdown House have supported me during the difficult struggles. I especially thank the Ashdown housemasters, Ann and Terry Orlando, Katie and Yuriy Roman, Adam Berinsky, and Dierdre Logan for their incredible support through my difficult times. They have provided vital support and advice.

I thank the many friends I have made over the years, especially Jon Chamberlain, D.W. Rowlands, Glenn Wagner, Jenna Klein, Andy Wright, Jeff Graham, Jeff Hodder, and many others. You have made my time here enjoyable. To my teammates, you have all been great friends and great supporters.

Brandon Luders has been an incredible friend and has always been there for me when I've been down. His support and encouragement (and the occasional Doctor Mario competition) has gotten me through many difficult nights, and always made me smile.

Most importantly, I would like to thank my family for their constant and unconditional love and support. Their selflessness and caring support cannot be put into words. Nobody else has supported me the way they have, and who I am today is due so much to them. I cannot possibly thank them enough.

This research was funded by a grant from the Ocean and Climate Change Institute at the Woods Hole Oceanographic Institution. The work was also partially funded by the United States Environmental Protection Agency through an EPA STAR fellowship, and by the WHOI Academic Programs Office. Marine sediment samples were provided by the International Ocean Discovery Program, namely the core repository at Texas A\&M University. Partial funding for the sampling trip to Texas A\&M was provided by the MIT Student Assistance Fund. 


\section{TABLE OF CONTENTS}

List of Tables $\quad 11$

$\begin{array}{ll}\text { List of Figures } & 13\end{array}$

$\begin{array}{ll}\text { Chapter 1. Introduction } & 15\end{array}$

$\begin{array}{ll}\text { 1.1 The Paleocene-Eocene Thermal Maximum } & 15\end{array}$

1.1.1 Methane hydrate dissociation 16

$\begin{array}{ll}\text { 1.1.2 Peatland conflagration } & 17\end{array}$

$\begin{array}{ll}\text { 1.1.3 Oxidation of epicontinental seaway sediment } & 18\end{array}$

$\begin{array}{ll}\text { 1.1.4 Orbital forcing } & 18\end{array}$

1.1.5 Kimberlite intrusions $\quad 19$

1.1.6 Comet impact 19

1.1.7 Magma-sediment interaction 20

1.2 Background and motivation $\quad 21$

1.2.1 ${ }^{187} \mathrm{Os} /{ }^{188} \mathrm{Os}$ evidence 22

1.2.2 Lead isotopes 25

1.3 Outline and summary of contributions 27

1.4 References $\quad 36$

Chapter 2. The importance of organic-rich shales to the geochemical cycles of rhenium $\begin{array}{ll}\text { and osmium } & 43\end{array}$

2.1 Abstract 43

2.2 Introduction $\quad 44$

2.3 Data sources and modeling methodology 47

2.3.1 Geochemical database of Re-Os-TOC concentrations in organic-rich sediments

2.3.2 Organic-rich sediments in the geologic record 50

2.4 Results and discussion $\quad 53$

2.4.1 Average ${ }^{187} \mathrm{Os} /{ }^{188} \mathrm{Os}$

2.4.2 Organic-rich sediments in the upper crustal Re and Os budgets 53

2.5 Conclusions $\quad 56$

$\begin{array}{ll}2.6 \text { References } & 71\end{array}$

$\begin{array}{ll}\text { 2.7 Supplementary data } & 78\end{array}$ 
Chapter 3. Lead isotope records across the PETM as recorded in DSDP Site 549 and ODP Site 690

3.1 Abstract 79

$\begin{array}{ll}3.2 \text { Introduction } & 79\end{array}$

3.3 Methods $\quad 81$

3.3.1 Samples $\quad 81$

3.3.2 Major and trace element analysis $\quad 82$

3.3.3 Lead isotope analysis $\quad 82$

3.4 Results $\quad 84$

3.4.1 Major and trace elements $\quad 84$

$\begin{array}{ll}3.4 .2 \text { Lead isotope analysis } & 87\end{array}$

$\begin{array}{ll}3.5 \text { Discussion } & 88\end{array}$

3.5.1 Major and trace elements of DSDP 549 sediments 88

3.5.2 Lead at the PETM 89

3.6 Conclusions 91

3.7 References 114

Chapter 4. Geochemical effects of contact metamorphism on the organic-rich Pierre Shale in the Raton Basin, New Mexico 117

$\begin{array}{ll}4.1 \text { Abstract } & 117\end{array}$

4.2 Introduction 117

4.3 Methods 119

$\begin{array}{ll}\text { 4.3.1 Field sampling } & 119\end{array}$

4.3.2 Sample processing 120

$\begin{array}{ll}\text { 4.3.3 Organic carbon analysis } & 120\end{array}$

$\begin{array}{ll}\text { 4.3.4 Major and trace element analyses } & 121\end{array}$

4.3.5 Re-Os isotope analysis $\quad 122$

4.4 Results 125

4.4.1 Organic carbon and total nitrogen 125

4.4.2 Major and trace element analysis $\quad 125$

$\begin{array}{ll}\text { 4.4.3 Re-Os isotope system } & 126\end{array}$

$\begin{array}{ll}4.5 \text { Discussion } & 129\end{array}$ 
4.5.1 Organic carbon depletion

4.5.2 Authigenic enrichment of redox sensitive elements 130

4.5.3 Mobilization of osmium and lead 132

$\begin{array}{ll}4.6 \text { Conclusion } & 133\end{array}$

$\begin{array}{ll}4.7 \text { References } & 158\end{array}$

Chapter 5. A modern submarine analog for the North Atlantic Magmatic Province - the $\begin{array}{ll}\text { Guaymas Basin, Mexico } & 163\end{array}$

$\begin{array}{ll}5.1 \text { Abstract } & 163\end{array}$

$\begin{array}{ll}5.2 \text { Introduction } & 164\end{array}$

$\begin{array}{ll}5.3 \text { Methods } & 166\end{array}$

5.3.1 Sample preparation 166

5.3.2 Organic carbon analysis 166

$\begin{array}{ll}\text { 5.3.3 Osmium isotope analysis } & 167\end{array}$

$\begin{array}{ll}\text { 5.3.4 Lead concentrations } & 167\end{array}$

$\begin{array}{ll}5.4 \text { Results } & 167\end{array}$

$\begin{array}{ll}\text { 5.4.1 Organic carbon } & 167\end{array}$

5.4.2 Lead concentrations 168

$\begin{array}{ll}\text { 5.4.3 Osmium isotope system } & 168\end{array}$

$\begin{array}{ll}5.5 \text { Discussion } & 169\end{array}$

5.5.1 Contact metamorphic processes 169

$\begin{array}{ll}\text { 5.5.2 Lead isotopes at the PETM } & 171\end{array}$

$\begin{array}{ll}\text { 5.5.3 Osmium isotope excursion at the PETM } & 172\end{array}$

$\begin{array}{ll}5.6 \text { Conclusions } & 174\end{array}$

$\begin{array}{ll}5.7 \text { References } & 188\end{array}$

$\begin{array}{ll}\text { Chapter 6. Conclusions } & 191\end{array}$

6.1 Summary of contributions 191

6.2 Implications and future work 193

6.2.1 Further exploration of thermal alteration at the PETM 193

6.2.2 Implications for other climatic events 195

$\begin{array}{ll}6.3 \text { References } & 197\end{array}$ 


\section{LIST OF TABLES}

\section{Chapter 2.}

Table 2.1 Geochemical database of Re and Os concentrations and isotopes, as well as age and TOC concentrations

Table 2.2 Summary of the median values as well as 95-percentile confidence intervals of various parameters calculated from the filtered database

\section{Chapter 3.}

Table 3.1 SARM trace element data of DSDP Site 549

Table 3.2 SARM major element analysis of DSDP Site 549

Table 3.3 Pb isotope compositions of ODP Site 690 and DSDP Site 549, age-corrected to the PETM

\section{Chapter 4.}

Table 4.1 Present-day Re and Os compositions in the Raton Basin samples

Table 4.2 Re and Os compositions age-corrected to the time of the intrusion $(24.16 \pm 1.01$ $\mathrm{Ma})$

Table 4.3 Re and Os compositions age-corrected to the time of deposition ( $\sim 70 \mathrm{Ma})$

Table 4.4 Total organic carbon and total nitrogen of the Raton samples and the respective isotope compositions

Table 4.5 SARM trace element data of the Raton Basin samples

Table 4.6 SARM major element data of the Raton Basin samples

Table 4.7 Type 1 regression correlation coefficients of linear and logarithmic regressions not corrected for age

Table 4.8 Age-corrected regression correlation coefficients of linear and logarithmic regressions, corrected to the time of the dike intrusion $(24.16 \pm 1.01 \mathrm{Ma})$

\section{Chapter 5.}

Table 5.1 Present day $\mathrm{Os}$ and $\mathrm{Pb}$ isotope compositions and concentrations of the Guaymas Basin sediments

Table 5.2 Total organic carbon and total nitrogen of the samples from the Guaymas Basin and the respective isotope compositions 


\section{LIST OF FIGURES}

\section{Chapter 1.}

Figure 1.1 Records of eccentricity, carbon isotope anomaly, and iron concentration across the Paleocene-Eocene transition

Figure 1.2 Seawater Os isotope record of the Paleocene-Eocene transition

Figure 1.3 Osmium and carbon isotope anomalies in DSDP Site 549 during the PETM

Figure 1.4 Conceptual model of the evolution of the Re-Os system and the U-Th-Pb systems

Figure 1.5 Examples of two $\mathrm{Pb}$ ingrowth trajectories of organic-rich sediments

\section{Chapter 2.}

Figure $2.1{ }^{187} \mathrm{Re} /{ }^{188} \mathrm{Os}$ values vs. TOC concentrations

Figure 2.2 Histogram showing the distribution of ${ }^{187} \mathrm{Re} /{ }^{188} \mathrm{Os}$

Figure 2.3 Histogram showing the means of each bootstrapped sample of the filtered database

Figure 2.4 Comparison of two proxy models

Figure 2.5 Relative contribution of Re and Os to the upper continental inventories stemming from organic-rich sediment

\section{Chapter 3.}

Figure 3.1 Normalized Co concentrations in core DSDP Site 549

Figure 3.2 Normalized Sr concentrations in core DSDP Site 549

Figure 3.3 Normalized As concentrations in core DSDP Site 549

Figure 3.4 Normalized Ba concentrations in core DSDP Site 549

Figure 3.5 Normalized MnO concentrations in core DSDP Site 549

Figure 3.6 Normalized enrichment factors in core DSDP Site 549

Figure 3.7 Lead isotope ratios corrected to the age of the PETM

Figure 3.8 Lead isotope ratios versus age

Figure 3.9 $\mathrm{Pb}-\mathrm{Pb}$ diagrams with linear regressions in core DSDP 549

Figure 3.10 $\mathrm{Pb}-\mathrm{Pb}$ diagrams with linear regressions in core ODP 690

Figure 3.11 Lead isotopic compositions of the DSDP and ODP cores 


\section{Chapter 4.}

Figure 4.1 Total organic carbon and bulk organic carbon $\delta^{13} \mathrm{C}$ of coal seams metamorphosed by dike intrusions in the Raton Basin, New Mexico

Figure 4.2 Google Maps image depicting the location of the Tinaja outcrop in northern New Mexico

Figure 4.3 Close-up aerial Google maps view of the Tinaja outcrop

Figure 4.4 Tinaja outcrop looking South

Figure 4.5 TOC and $\delta^{13} \mathrm{C}$ of the Raton Basin samples

Figure 4.6 Total N concentrations of the Raton Basin samples

Figure 4.7 Uranium, $\mathrm{Th}$, and $\mathrm{Pb}$ concentrations of the Raton Basin samples

Figure 4.8 Osmium concentrations and ${ }^{187} \mathrm{Os} /{ }^{188} \mathrm{Os}$ of the Raton Basin samples

Figure 4.9 Rhenium concentrations of the Pierre Shale samples

Figure 4.10 Age-corrected Os concentrations and isotopic compositions

Figure 4.11 Isochron diagram

Figure 4.12 Two-component mixing diagram for the Tinaja outcrop sediments

\section{Chapter 5.}

Figure 5.1 Bathymetry of the Guaymas Basin within the Gulf of California

Figure 5.2 Schematic of DSDP Site 477 in the Guaymas Basin

Figure 5.3 Total organic carbon concentrations and $\delta^{13} \mathrm{C}$ of the Guaymas Basin sediment samples

Figure 5.4 Total nitrogen concentrations of the Guaymas Basin samples

Figure 5.5 Lead concentrations in the Guaymas Basin DSDP Site 477 profile

Figure 5.6 Osmium concentrations of the samples from the Guaymas Basin DSDP Site 477

Figure 5.7 Osmium versus TOC concentrations

Figure 5.8 Osmium isotopic composition with depth in DSDP Site 477

Figure 5.9 Osmium isotope composition compared to inverse osmium concentrations in Guaymas Basin DSDP Site 477 samples

Figure 5.10 Linear mixing relationship between Os isotope composition and Os concentrations for the five samples closest to the intrusive contact at DSDP Site 477

Figure 5.11 Relationship between the calculated fraction of carbon at the PETM derived from organic-rich sediments, and the ${ }^{187} \mathrm{Os} /{ }^{188} \mathrm{Os}$ of those sediments 


\section{CHAPTER 1.}

\section{Introduction}

\subsection{The Paleocene-Eocene Thermal Maximum}

In the early Eocene, Earth's surface temperature rose dramatically $\left(3-8^{\circ} \mathrm{C}\right)$ and rapidly over a period of $\sim 6 \mathrm{kyr}$, followed by a more gradual $(\sim 150-200 \mathrm{kyr})$ return to pre-event temperatures (e.g. Norris and Röhl, 1999). This hyperthermal event - known as PaleoceneEocene Thermal Maximum (PETM; Kennett and Stott, 1991) - began at the Paleocene-Eocene boundary (56 Ma; Gradstein et al., 2012) and is marked by a pronounced decrease in ${ }^{13} \mathrm{C} /{ }^{12} \mathrm{C}$ (Figure 1.1) in the terrestrial and marine records, and is found in both inorganic carbonates as well as organic matter (e.g. Tipple et al., 2011). The abrupt decrease in the ${ }^{13} \mathrm{C} /{ }^{12} \mathrm{C}$ - the carbon isotope excursion (CIE) - of terrestrial and marine organic matter as well as planktonic and benthic foraminifera was accompanied by a mass extinction of the latter (Thomas and Shackleton, 1996). The isotope excursion is also associated with a large increase in $\mathrm{CaCO}_{3}$ dissolution that points to more acidic seawater (Zachos et al., 2005; Chun et al., 2010). Massive release of isotopically light carbon into the ocean-atmosphere system must have triggered the PETM.

Estimates of the amount of carbon released depend on the isotope composition of the source carbon, the mass and carbon isotope composition of the Paleocene surface reservoir, as well as the magnitude of the CIE (McInerney and Wing, 2011). Ranges of the latter very widely, with estimates as high as $-5 \%$ in terrestrial records and as low as $-2.5 \%$ in marine records (Smith et al., 2007; McInerney and Wing, 2011). Estimates for the amount of carbon released are thus similarly variable. Higgins and Schrag (2006) estimate that only $1700 \mathrm{Gt}$ of methane with 
$\delta^{13} \mathrm{C}=-60 \%$ would be required, or $4500 \mathrm{Gt}$ of organic carbon with $\delta^{13} \mathrm{C}=-25 \%$. Other estimates of the total carbon release for carbon with $\delta^{13} \mathrm{C}=-60 \%$ range from $1100 \mathrm{Gt}$ (Dickens et al., 1995) to $4600 \mathrm{Gt}$ (McInerney and Wing, 2011) depending on the parameters used.

Several hypotheses - briefly reviewed below - have been proposed to explain the CIE and sudden warming during the PETM. The difficulties with testing these hypotheses create a major obstacle towards the goal of determining the cause(s) of this unusual climate event. This goal is significant because the PETM has been proposed as a suitable analogue for carbon cycle perturbations in the Anthropocene (e.g. Zachos et al., 2008; Hönisch et al., 2012).

\subsubsection{Methane hydrate dissociation}

Perhaps the most popular and widely investigated hypothesis for the PETM is that the CIE was primarily caused by release of methane from the dissociation of methane clathrates in continental margin sediments. The stability field of methane clathrates expands with increasing pressure and decreasing temperature, making these delicate crystal structures sensitive to pressure and temperature changes. If the oceans warmed sufficiently, clathrate-bound methane could have been released to the ocean-atmosphere system (Dickens et al., 1995, 1997; Dickens, 2003). This hypothesis has gained traction due to the very negative isotope signature of carbon from this source $\left(\delta^{13} \mathrm{C}\right.$ of about $-60 \%$ ), requiring the release of much smaller masses of carbon to cause the large CIE (Bains et al., 1999). Release of as little as $\sim 1100 \mathrm{Gt}$ carbon of this isotopic composition might cause a global excursion of $-2.5 \%$ in the $\delta^{13} \mathrm{C}$ record of carbonate (Dickens et al., 1995). However, a much larger mass of carbon is needed to explain the observed extensive dissolution of carbonates and shoaling of the lysocline, indicating that (a) carbon source(s) with isotope values higher than methane must have been involved (Zachos et al., 2005; Panchuk et al., 
2008). Zeebe et al. (2009), however, indicate that the carbonate dissolution may be consistant with a much smaller amount of carbon $(<3,000 \mathrm{Gt} \mathrm{C})$, consistant with a methane source. Another criticism of this hypothesis is the uncertainty associated with identifying the unknown trigger mechanism for the release of methane (Katz et al., 1999, 2001). Some evidence has been presented for changing ocean circulation during the PETM (Bralower et al., 1995; Thomas et al., 2002; Tripati and Elderfield, 2005; Nunes and Norris, 2006; Sluijs et al., 2007) and sediment slumping (Katz et al., 2001), which may have provided the necessary triggers for the methane release. In addition, volcanic degassing of $\mathrm{CO}_{2}$ from circum-Caribbean and North Atlantic igneous provinces may have also led to initial warming that could have triggered methane release (Bralower et al., 1997; Schmitz and Pujalte, 2003; Schmitz et al., 2004). An additional criticism is that temperatures in the Paleocene were significantly warmer than today, reducing the fraction of the seafloor capable of hosting methane clathrates. Based on this reasoning Pagani et al. (2006) argue that the inventory of methane clathrates was too small to explain the entire CIE.

\subsubsection{Peatland conflagration}

Kurtz et al. (2003) suggest a terrestrial rather than a marine source of isotopically light carbon - the extensive combustion of peat deposits or terrestrial biomass. Such conflagration could have resulted from increasing atmospheric $\mathrm{O}_{2}$ concentrations, dryer climates, and/or uplift of coal basins (e.g. coal fires triggered by lightning). The tight coupling of $\delta^{13} \mathrm{C}$ and $\delta^{34} \mathrm{~S}$ records across the PETM provides additional support for this hypothesis (Zachos et al., 2001; Paytan et al., 1998). However, due to the relatively high isotopic value of the carbon source, this scenario necessitates the burning of very large quantities of carbon (McInerney and Wing, 2011; Page et al., 2011). The lack of evidence for large scale burning of peat, such as an increased flux of soot 
or graphitic black carbon in globally distributed sediment cores poses an additional challenge for this hypothesis (Moore and Kurtz, 2008).

\subsubsection{Oxidation of epicontinental seaway sediments}

In their critique of the Kurtz et al. hypothesis, Higgins and Schrag (2006) proposed that the drying of epicontinental seaways may have exposed large quantities of organic carbon that could have been rapidly oxidized to $\mathrm{CO}_{2}$ by bacterial respiration or dessication of the exposed sediments, causing the observed CIE at the PETM. While sea level rose immediately before the CIE (Sluijs et al., 2008; Harding et al., 2011; Handley et al., 2011), tectonic uplift (from volcanism or continental collision) may have led to subaerial exposure. This hypothesis has

proven difficult to test, but criticisms include the lack of carbon injection from the drying of epicontinental seaways at other times in earth's history (Nicolo et al., 2007) as well as the special set of circumstances that would have needed to occur in order for this mechanism to have caused the PETM (Dickens, 2011).

\subsubsection{Orbital forcing}

Another possibility is that the PETM was driven by orbital forcing which warmed the climate to a threshold that triggered a positive feedback (Lourens et al., 2005), such as carbon release from thawing permafrost (DeConto et al., 2012). This hypothesis is appealing because it can explain the subsequent hyperthermals, such as the "Elmo" (Eocene Thermal Maximum 2 [ETM2]) and "X" (ETM3) events (Galeotti et al., 2010). While this scenario has been modeled, little definitive supporting evidence has been provided. It is noteworthy that, while subsequent hyperthermals do seem to follow Earth's 400-kyr eccentricity cycle, the PETM is an exception 
and does not seem to closely follow the eccentricity cycle, indicating that there was a trigger other than orbital forcing at play (Zachos et al., 2010). However, high-resolution stable-isotope records indicate that the PETM is in phase with 100 kyr eccentricity cycle (Littler et al., 2014). Additionally, the PETM corresponds well with a peak in the long modulation of obliquity (DeConto et al., 2012).

\subsubsection{Kimberlite intrusions}

Recently, the possibility of a deep-Earth (endogenic) trigger mechanism has emerged that links the initial warming at the PETM with the emplacement of a Kimberlite cluster in northern Canada. This hypothesis centers on models of the onset of the PETM that are suggestive of a two-stage process at the onset of the PETM (Carozza et al., 2011). The rapid emplacement of a large cluster of Kimberlite pipes in the Lac de Gras region in northern Canada could explain the "pre-isotope excursion stage" in which large amounts (900-1100 Pg C) of methane were emitted in less than 500 years (Patterson and Francis, 2013). The second stage of warming could then be explained by the dissociation of methane clathrates that followed the initial magmatic triggering mechanism. While this hypothesis remains plausible, little supporting evidence aside from the timing of these magmatic emplacements has been presented.

\subsubsection{Comet impact}

In contrast to the terrestrial trigger mechanisms discussed above, Kent et al. (2003) hypothesized that the cause of the CIE may have been a volatile-rich comet impacting Earth, releasing isotopically light extraterrestrial carbon to the atmosphere-ocean system. Evidence supporting this hypothesis includes increased kaolinite accumulation rates, an accumulation of 
elongated single domain magnetite of presumably extraterrestrial origin at three drill cores in New Jersey on the Atlantic Coastal Plain, and a small iridium anomaly in an expanded bathyal section at Zumaya, Spain. Additionally, the very rapid onset of the carbon release (Wright and Schaller, 2013) is consistent with an instantaneous release of carbon, which would be expected from a comet impact. However, several objections have been raised against this hypothesis. Iridium was not significantly enriched relative to other trace metals in the Zumaya section, the ${ }^{187} \mathrm{Os} /{ }^{188} \mathrm{Os}$ isotope signature of the horizon that is slightly enriched in Ir is incompatible with an extraterrestrial origin of the platinum group metals (Schmitz et al., 2004), and the flux of extraterrestrial ${ }^{3} \mathrm{He}$ was not significantly elevated (Farley and Eltgroth, 2003; Dickens and Francis, 2004). In addition, studies by Kopp et al. (2007) and Lippert and Zachos (2007) showed that the single-domain magnetite was likely produced by bacteria and did not condense from an ejection plume during a high-velocity impact.

\subsubsection{Magma-sediment interaction}

Another potential deep-Earth trigger mechanism links the evolution of climate and life to magmatism associated with the North Atlantic Magmatic Province (NAMP). This hypothesis asserts that the PETM was triggered by an intrusion of a large magmatic sill complex into organic-rich sediments in the North Atlantic (Svensen et al., 2004; Dickens, 2004). The intrusion of magma into sedimentary rocks causes heating and metamorphic reactions in a thermal aureole around the intrusion (e.g. Cooper, 2006; Ledevin, 2010; Ledevin et al., 2012). If these sediments are rich in organic matter, large volumes of carbon dioxide and/or methane could be released during contact metamorphism (Cooper, 2006; Cooper et al., 2007). Since the source of the volatile carbon is organic material, which is enriched in ${ }^{12} \mathrm{C}$ relative to ${ }^{13} \mathrm{C}$, large- 
scale release of isotopically light carbon into the ocean-atmosphere system could explain both the observed increase in global surface temperature during the PETM as well as the CIE. Svensen et al. $(2004,2010)$ provide evidence supporting this hypothesis. These authors point to the presence of "hydrothermal vent complexes" connecting the metamorphic aureoles to the PETM ocean bottom where the thermogenic gases may have been released. High-precision radiometric dating of large sill intrusions into the Cretaceous-Paleocene mudstones of the North Atlantic Møre and Vøring basins, which have been dated at 55.6 \pm 0.3 and $56.3 \pm 0.4 \mathrm{Ma}$, demonstrates the simultaneous timing of the intrusions and the PETM (Svensen et al., 2004, 2010; Storey et al., 2007; Westerhold et al., 2009). Criticisms of this hypothesis include the need for very large quantities of hydrocarbons to be released and oxidized in order to cause the CIE (Dickens, 2004) and the failure of this hypothesis to explain the subsequent hyperthermal events (Dickens, 2011). However, the possibility that the PETM was triggered by thermal alteration of organic-rich sediments in the North Atlantic Magamatic Province cannot be ruled out.

\subsection{Background and motivation}

To date, it appears that no single hypothesis can explain the PETM $\delta^{13} \mathrm{C}$ signal and subsequent warming in its entirety. More likely, a combination of trigger mechanisms and feedbacks led to the large CIE and related global warming (e.g. Sluijs et al., 2006). In this thesis, I test whether there is geochemical evidence for the intrusion of magmatic dikes and sills into organic-rich sediments in the North Atlantic that would supplement evidence from geophysical investigations of the sedimentary strata along the continental margins in the North Atlantic (Svensen et al., 2004, 2010), as well as radiometric dating of these intrusions (Storey et al., 2007; Svensen et al., 2010). In all likelihood, this hypothesis cannot explain the entire carbon isotope excursion. Rather, a combination of processes led to the large CIE and warming event. I 
specifically test whether geochemical evidence is consistent with the hypothesis that magmatic intrusions into organic-rich marine sediments provided an initial trigger mechanism for the release of additional light carbon from other sources.

\subsection{1 ${ }^{187} \mathrm{Os} /{ }^{188}$ Os evidence}

Existing ${ }^{187} \mathrm{Os} /{ }^{188}$ Os data from marine sediments that span the PETM show an excursion to more radiogenic seawater coincident with the carbon isotope excursion (Figure 1.2; Ravizza et al., 2001). This $\sim 10 \%$ increase in ${ }^{187} \mathrm{Os} /{ }^{188} \mathrm{Os}$ has been interpreted as an increased flux of radiogenic land-derived Os (i.e. high ${ }^{187} \mathrm{Os} /{ }^{188} \mathrm{Os}$, reflecting the large time-integrated Re/Os of continental crust compared to the Earth's mantle and extraterrestrial matter) that was triggered by increased global temperatures and the associated climate-weathering feedback (e.g. Ebelmen, 1845; Rubey, 1951; Walker et al., 1981; Kump et al., 2000; Villasante-Marcos et al., 2009; Beaulieu et al., 2012).

I challenge this interpretation of the excursion in ${ }^{187} \mathrm{Os} /{ }^{188} \mathrm{Os}$ across the PETM and provide an alternative hypothesis that the increase in ${ }^{187} \mathrm{Os} /{ }^{188} \mathrm{Os}$ reflects the release of radiogenic Os from organic-rich sediments along the continental margins of the North Atlantic that were intruded by magmatic dikes and sills. Sediments with high organic matter content are enriched in many redox-sensitive elements (e.g. U, Os, Re, Mo, V, Te). Some of these elements have radioactive isotopes that produce radiogenic decay products. Decay products of volatile elements could accumulate in organic-rich marine sediments. The thermal metamorphism of these sediments may have not only released isotopically light carbon into the ocean-atmosphere system, but also volatile compounds of elements such as osmium and lead (Os as volatile Ostetroxide, $\mathrm{Pb}$ as, for instance, volatile methylated $\mathrm{Pb}$ compounds). 
In order for the hypothesis to be viable, the observed excursion in the marine ${ }^{187} \mathrm{Os} /{ }^{188} \mathrm{Os}$ record (Figure 1.3) has to be consistent with possible releases of Os from submarine organic-rich sediments. Osmium has a relatively short residence time in seawater of $\sim 10-50 \mathrm{kyr}$ (PeuckerEhrenbrink and Ravizza, 2000). The mass balance calculations Ravizza et al. (2001) carried out constrain the additional flux of radiogenic Os released during the PETM to $\sim 25 \%$ of the pre- and post-PETM Os flux. Estimates of the ratio of osmium and carbon released from metamorphosed organic-rich sediments inform mass balance calculations involving the coupled release of radiogenic Os and isotopically light carbon.

A simple model is used to estimate the amount of organic-rich sediment that would need to be heated to account for the $\mathrm{C}$ and Os isotope excursions, as well as the timescales of release. I adapt the Ravizza et al. (2001) model to include an additional source of Os to seawater - Os released from the heating of organic-rich sediments during contact metamorphism. During the PETM the ${ }^{187} \mathrm{Os} /{ }^{188} \mathrm{Os}$ value of seawater is assumed to be a mixture of hydrothermal Os $\left({ }^{187} \mathrm{Os} /{ }^{188} \mathrm{Os}=0.12\right.$ ), continental Os runoff (with typical ${ }^{187} \mathrm{Os} /{ }^{188} \mathrm{Os}$ values between 0.5 and 1.5 ), and Os from organic-rich marine sediments (typical ${ }^{187} \mathrm{Os} /{ }^{188} \mathrm{Os}$ values discussed in later chapters). Making the assumption that the only change between the Os isotope balance at the PETM and the post-PETM periods was the additional Os source from the organic-rich sediments, the following system of equations can be written:

$$
\begin{aligned}
& R_{s w}(\text { post }- \text { PETM })=R_{r} F_{r}(\text { post }- \text { PETM })+R_{h} F_{h}(\text { post }- \text { PETM }) \\
& R_{s w}(\text { PETM })=R_{r} F_{r}(\text { PETM })+R_{h} F_{h}(\text { PETM })+R_{o} F_{o}(\text { PETM }) \\
& F_{r}(\text { post }- \text { PETM })+F_{h}(\text { post }- \text { PETM })=1 \\
& F_{r}(\text { PETM })+F_{h}(\text { PETM })+F_{o}(\text { PETM })=1 \\
& \frac{F_{r}(\text { post }- \text { PETM })}{F_{r}(\text { PETM })}=\frac{F_{h}(\text { post }- \text { PETM })}{F_{h}(\text { PETM })}
\end{aligned}
$$


where $\mathrm{F}$ is the mole fraction of ${ }^{188} \mathrm{Os}$ in seawater, $\mathrm{R}$ is the ${ }^{187} \mathrm{Os} /{ }^{188} \mathrm{Os}$, and the subscripts sw, $\mathrm{r}, \mathrm{h}$, and o indicate seawater, rivers, hydrothermal, and organic-rich sediments, respectively. The first two equations are isotope balances, the next two equations are mass balances, and the final equation comes from the assumption that the relative contributions from hydrothermal and river inputs do not change between the PETM and the post-PETM. This assumption, while likely untrue, allows me to examine a simple end member case in which the entire Os isotope excursion is caused by thermal alteration of organic-rich sediments.

For a given ${ }^{187} \mathrm{Os} /{ }^{188} \mathrm{Os}$ of organic-rich sediments (discussed in more detail in chapters 2 and 5), the system of equations above can be used to calculate the mole fraction of ${ }^{188} \mathrm{Os}$ in seawater derived from organic-rich sediments during the PETM. Assuming an average Os concentration of $10 \mathrm{pg} / \mathrm{L}$ in the ocean during the PETM (identical to today), this estimate can be used to calculate the total number of moles of Os released from organic-rich sediments in the NAMP during the PETM. The relative mobilizations of Os and organic carbon (discussed further in Chapter 5) can then be used to determine the total mass of organic carbon released from organic-rich sediments during the PETM. This can then be compared to existing estimates of carbon released during the PETM (e.g. $\sim 2500 \mathrm{Gt}$, with $\delta^{13} \mathrm{C}$ of the organic matter around $50 \%$ ).

Assuming that $2500 \mathrm{Gt}$ of light carbon were released by this process, and assuming an average of 2 wt. $\% \mathrm{C}_{\text {org }}$ in such sediments, $\sim 125,000 \mathrm{Gt}\left(1.25 \times 10^{17} \mathrm{~kg}\right)$ of organic-rich sediment must have lost its entire $\mathrm{C}_{\text {org }}$ inventory. This corresponds to a total sediment volume of 62,500 $\mathrm{km}^{3}\left(\rho=2 \mathrm{~g} / \mathrm{cm}^{3}\right)$. This volume is two orders of magnitude smaller than the estimated size of the North Atlantic Magmatic Province (Svensen et al., 2004), indicating that this trigger and release 
mechanism could have accounted for the entire amount of carbon released at the PETM and further confirming that this is a potentially feasible hypothesis.

\subsubsection{Lead isotopes}

If volatile $\mathrm{Pb}$ was released together with radiogenic Os from metamorphosed organic-rich sediments, the isotope signature of this lead should be distinct from that of average upper continental crust (Figure 1.4). The unique $\mathrm{Pb}$ isotope signature results from the enrichment of $\mathrm{U}$, but not Th, in organic-rich sediments compared to typical oxic sediments that more closely resemble the composition of the eroding upper continental crust. Such oxic sediments typically have $\mathrm{Th} / \mathrm{U}$ values of $\sim 3$ for juvenile sediments to 7 for cratonic sediments (Carpentier et al., 2013). The $U$ enrichment in reducing (organic-rich) sediments that results from the redoxsensitive nature of this element can lead to $\mathrm{Th} / \mathrm{U}$ values significantly smaller than unity. For instance, unpublished data for the organic-rich (4-10 wt.\% TOC) New Albany Shale, Kentucky, are characterized by $\mathrm{Th} / \mathrm{U}$ and $\mathrm{U} / \mathrm{Pb}$ values of 0.5 and 1.0 , respectively (Ravizza, pers. comm., 2001). Unpublished U/Pb data (Ravizza, pers. comm., 2001) for the organic-rich Bakken Shale, North Dakota, yield values of $\sim 1$, about an order of magnitude higher than typical values for continental crust and sediments (e.g. post-Archean shale; Taylor and McLennan, 1985; McLennan, 2001). For the purpose of a sensitivity calculation, I assume - based on the data discussed above - that the $\mathrm{Th} / \mathrm{U}$ of reducing sediments is about an order of magnitude smaller than that of typical continental crustal rocks. The U-enrichment causes much more rapid ingrowth of uranogenic $\left({ }^{206} \mathrm{~Pb}\right.$ from ${ }^{238} \mathrm{U},{ }^{207} \mathrm{~Pb}$ from $\left.{ }^{235} \mathrm{U}\right) \mathrm{Pb}$ compared with thorogenic $\left({ }^{208} \mathrm{~Pb}\right.$ from $\left.{ }^{232} \mathrm{Th}\right) \mathrm{Pb}$. Lead with elevated ${ }^{206} \mathrm{~Pb} /{ }^{204} \mathrm{~Pb}$ and ${ }^{207} \mathrm{~Pb} /{ }^{204} \mathrm{~Pb}$ over ${ }^{208} \mathrm{~Pb} /{ }^{204} \mathrm{~Pb}$ values should therefore characterize sediments at the onset of the PETM, provided the proposed magmatic trigger mechanism is valid and thermogenic $\mathrm{Pb}$ is released in sufficient quantities to be detected 
in contemporaneous (PETM) marine sediments. An additional complication may result from the short residence time of $\mathrm{Pb}$ in seawater. Unless volatile $\mathrm{Pb}$ reached the atmosphere, a global $\mathrm{Pb}$ isotope anomaly in PETM sediments is unlikely to have occured. Instead, a local signature restricted to the Atlantic Ocean, possibly only the North Atlantic, is a more likely consequence.

In order to evaluate this model quantitatively, the following assumptions are made: Oxic sediments have $\mathrm{U}, \mathrm{Th}$, and $\mathrm{Pb}$ concentrations typical of post-Archean shale $(3.1 \mu \mathrm{g} / \mathrm{g} \mathrm{U} ; 14.6$ $\mu \mathrm{g} / \mathrm{g}$ Th; $20 \mu \mathrm{g} / \mathrm{g} \mathrm{Pb}$; Taylor and McLennan, 1985). Reducing sediments have the same Th and $\mathrm{Pb}$ concentrations, but 10-fold higher $\mathrm{U}$ concentrations. Two scenarios are shown: The first (gray squares and broken line in Figure 1.5) assumes that the magma intruded organic-rich sediments that had been deposited in the late Cretaceous (96 Ma), and had evolved with a $\mu$ $\left({ }^{238} \mathrm{U} /{ }^{204} \mathrm{~Pb}\right)$ of 99 and a $\kappa\left({ }^{232} \mathrm{Th} /{ }^{238} \mathrm{U}\right)$ of 0.49 from 96 to $56 \mathrm{Ma}$ (gray field in Figure 1.5). The second scenario (black circles and stippled line in Figure 1.5) assumes that the magma intruded organic-rich sediments that had been deposited just 5 million years prior to the PETM. The starting $\mathrm{Pb}$ isotope compositions of the organic-rich sediments deposited $96 \mathrm{Ma}$ and $61 \mathrm{Ma}$ were ingrowth-corrected from present-day values of ${ }^{206} \mathrm{~Pb} /{ }^{204} \mathrm{~Pb}=18.70,{ }^{207} \mathrm{~Pb} /{ }^{204} \mathrm{~Pb}=15.65$, and ${ }^{208} \mathrm{~Pb} /{ }^{204} \mathrm{~Pb}=38.70$ (Galer and Goldstein, 1996), and then aged according to $\mu$ and $\kappa$ values specified above. The $\mathrm{Pb}$ isotopes in the younger organic-rich sediments follow the same ingrowth trajectories as the older organic-rich sediments, just for a shorter period of time. While the first scenario presents a realistic case for the magma intrusions in the North Atlantic margins, the latter case provides a minimum estimate for the expected $\mathrm{Pb}$ isotope anomaly. Figure 1.5 shows the temporal evolution of the ${ }^{206} \mathrm{~Pb} /{ }^{204} \mathrm{~Pb}$ anomaly, normalized to the temporal evolution of post-Archean shale $(\Delta=0)$ with $\mu=9.9, \omega=48$ and $\kappa=4.9$. A similar, albeit more than 10 -times smaller anomaly should be visible in the ${ }^{207} \mathrm{~Pb} /{ }^{204} \mathrm{~Pb}$ signature (not shown in Figure 1.5). If lead 
is mobilized from the organic-rich sediments upon magma intrusion, released into the oceanatmosphere system without fractionation and redeposited into PETM sediments, the isotope anomaly $(\Delta)$ is located in the sediment horizon where it was deposited, as most PETM sediments were deposited under oxic conditions (red field in Figure 1.5) and isotopes were likely to follow an ingrowth trajectory similar to post-Archean shale. In order to make the scenario more realistic, it is assumed that only $10 \%$ of the $\mathrm{Pb}$ budget of these PETM sediments is derived from older organic-rich sediments that carry the anomalous ${ }^{206} \mathrm{~Pb} /{ }^{204} \mathrm{~Pb}$ signature. The remainder of the lead is typical upper crustal lead (present-day values: ${ }^{206} \mathrm{~Pb} /{ }^{204} \mathrm{~Pb}=18.70 ;{ }^{207} \mathrm{~Pb} /{ }^{204} \mathrm{~Pb}=15.65$; ${ }^{208} \mathrm{~Pb} /{ }^{204} \mathrm{~Pb}=38.70$; see Galer and Goldstein, 2001; note that the starting $\mathrm{Pb}$ isotope compositions of the organic-rich sediments deposited $96 \mathrm{Ma}$ and $61 \mathrm{Ma}$ were ingrowth-corrected from these present-day values). The y-axis in Fig. 1.5 shows the isotope anomaly expected in PETM sediments if only $10 \%$ of the total $\mathrm{Pb}$ budget is derived from older organic-rich sediments.

A negative test result does not disprove that magma-sediment interaction was not the trigger of the initial PETM warming, because it is also possible that little or no $\mathrm{Pb}$ reached seawater and was distributed by the currents in the North Atlantic (or beyond). Instead, $\mathrm{Pb}$ may have been scavenged and redeposited in local sediments.

\subsection{Outline and summary of contributions}

This thesis discusses the geochemical evidence from $\mathrm{Pb}, \mathrm{Os}$, and organic carbon to place constraints on the extent the carbon isotope excursion during the PETM may have been caused by contact metamorphism of organic-rich sediments. I attempt to better constrain the unknown parameters in the model described above in section 1.2.1 to create a more accurate mass balance and determine whether thermal alteration provides a feasible trigger mechanism for the PETM. 
- Chapter 2 constrains the effect that organic-rich sediments may have in the global surficial rhenium and osmium budgets. The first contribution of this chapter is the construction of a geochemical database of Re, Os, and organic carbon concentrations and ${ }^{187} \mathrm{Os} /{ }^{188} \mathrm{Os}$ values of organic-rich sediments from data available in the literature. I then utilize this database to constrain the average initial ${ }^{187} \mathrm{Os} /{ }^{188} \mathrm{Os}$ and ${ }^{187} \mathrm{Re} /{ }^{188} \mathrm{Os}$ for these sediments. Two estimates of the age distribution of organic-rich sediments or organic carbon burial through the geologic record are used to determine an average ${ }^{187} \mathrm{Os} /{ }^{188} \mathrm{Os}$ of this type of sediment and the contribution these sediments make to the upper continental crustal Re and Os inventories. This chapter explains how, despite their scarcity in the earth's crust, organic-rich shales account for a large portion $(\sim 70 \%)$ of the upper continental crustal (UCC) rhenium inventory and a smaller portion $(\sim 10 \%)$ of the osmium inventory. This chapter also provides further constraints on the ${ }^{187} \mathrm{Re} /{ }^{188} \mathrm{Os}$ value of organic-rich sediments, necessary for the mass balance calculations at the PETM.

- Chapter 3 focuses on the $\mathrm{Pb}$ isotope system by presenting $\mathrm{Pb}$ isotope profiles of two marine sediment cores from the Ocean Drilling Program (ODP) and the Deep Sea Drilling Project (DSDP). The focus of this chapter is to test whether the $\mathrm{Pb}$ isotope ratios in the sedimentary record during the PETM are consistent with an additional source of lead from organic-rich sediments as described above. Samples from cores collected at two different locations (DSDP 549 from the North Atlantic, and ODP 690 from the Southern Ocean) were analyzed for major and trace element concentrations as well as lead isotope compositions. Uranium, thorium, and lead concentrations were also determined by isotope dilution to age-correct the $\mathrm{Pb}$ isotopic ratios for the age of the 
sediments. This chapter provides insight into processes that may have occurred during the PETM to produce global changes in the $\mathrm{Pb}$ isotope ratios.

- Chapter 4 examines the effects of contact metamorphic processes and thermal alteration on the geochemistry of a potential terrestrial analog for the North Atlantic Magmatic Province. The primary contribution of this chapter is to determine the effect of contact metamorphism on the Re-Os and U-Th-Pb systems to constrain the ratios of C, Os, and $\mathrm{Pb}$ that are mobilized from organic-rich sediments during metamorphic heating. This chapter also examines the concentrations of major and trace elements within a metamorphic aureole from a dike intrusion, the late Oligocene Eagle Rock dike intrusion into the Pierre Shale in northern New Mexico.

- Chapter 5 examines how the processes of $\mathrm{C}$, $\mathrm{Os}$, and $\mathrm{Pb}$ mobilization from contact metamorphism might be different in a submarine environment. This chapter examines a vertical sediment profile above a magmatic intrusion in the Guaymas Basin, a modern spreading center in which intrusive magmatism is thermally altering organic-rich sediments. This chapter aims to determine the relative proportions of mobilization of $\mathrm{C}$, $\mathrm{Os}$, and $\mathrm{Pb}$, but focuses on a submarine environment as opposed to the terrestrial environment examined in chapter 4.

- Chapter 6 offers concluding remarks and suggestions for future research 


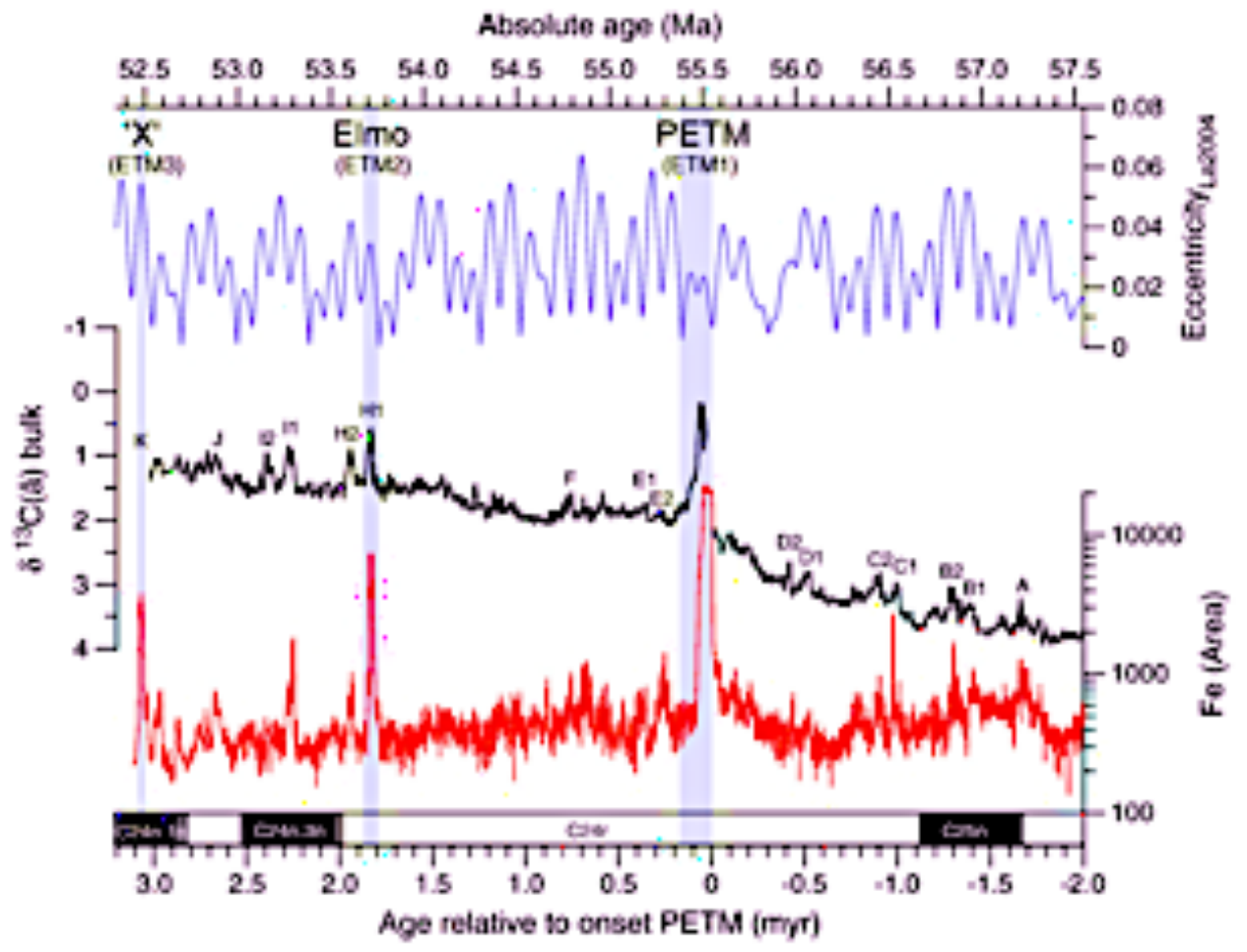

Figure 1.1 Records of eccentricity (top, right axis), carbon isotope anomaly measured in bulk carbonates (middle, left axis) and iron concentration (bottom, right axis) across the PaleoceneEocene transition, including the PETM and other Eocene hyperthermal events (Elmo, X) from ODP Site 1262 near the base of the Walvis Ridge in the South Atlantic (from Zachos et al., 2010). 


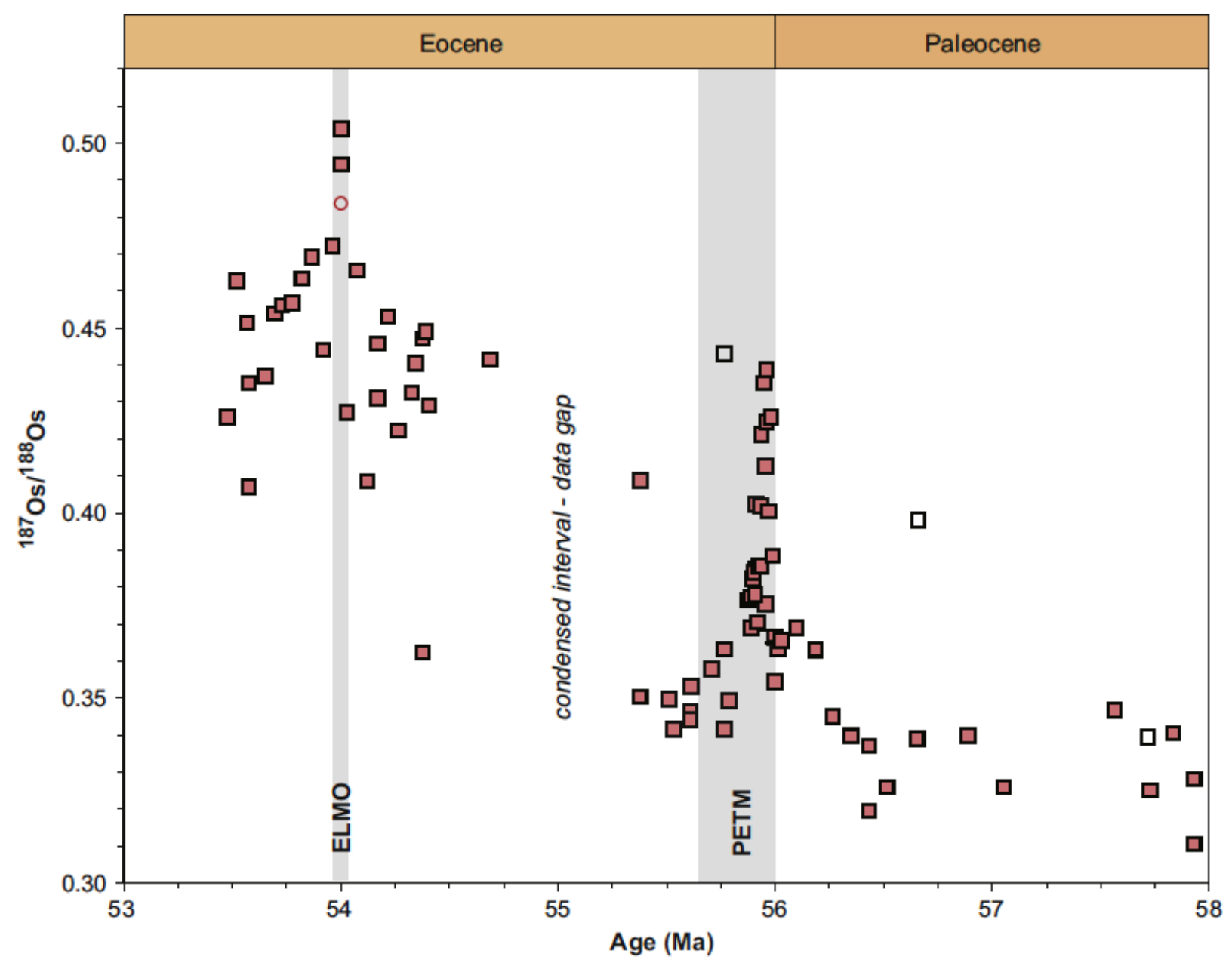

Figure 1.2 Seawater Os isotope record of the Paleocene-Eocene transition (from PeuckerEhrenbrink and Ravizza, 2012) measured in bulk sediment. DSDP 549 = pink squares (Ravizza et al., 2001; Peucker-Ehrenbrink and Ravizza, in prep.); LL44-GPC3 = open squares (Pegram and Turekian, 1999); DSDP 39 - open red circle (Peucker-Ehrenbrink et al., 1995). Initial ${ }^{187} \mathrm{Os} /{ }^{188}$ Os bulk sediment values from the P-E boundary at Zumaya (Schmitz et al., 2004) that agree well with DSDP 549 data are not shown. Gray vertical bars indicate the approximate timings and durations of the PETM and Elmo (ETM2, cf. Fig. 1.1) events. Analytical uncertainties are smaller than the symbol sizes. 




Figure 1.3 Osmium (black squares, right axis) and carbon isotope (open squares and circles, left axis) anomalies in sediments from DSDP Site 549 during the PETM (from Ravizza et al., 2001). Note that the time scale (top x-axis) has not been adjusted to the Geologic Time Scale 2012 that places the onset of the PETM at $56 \mathrm{Ma}$ (Gradstein et al., 2012). 


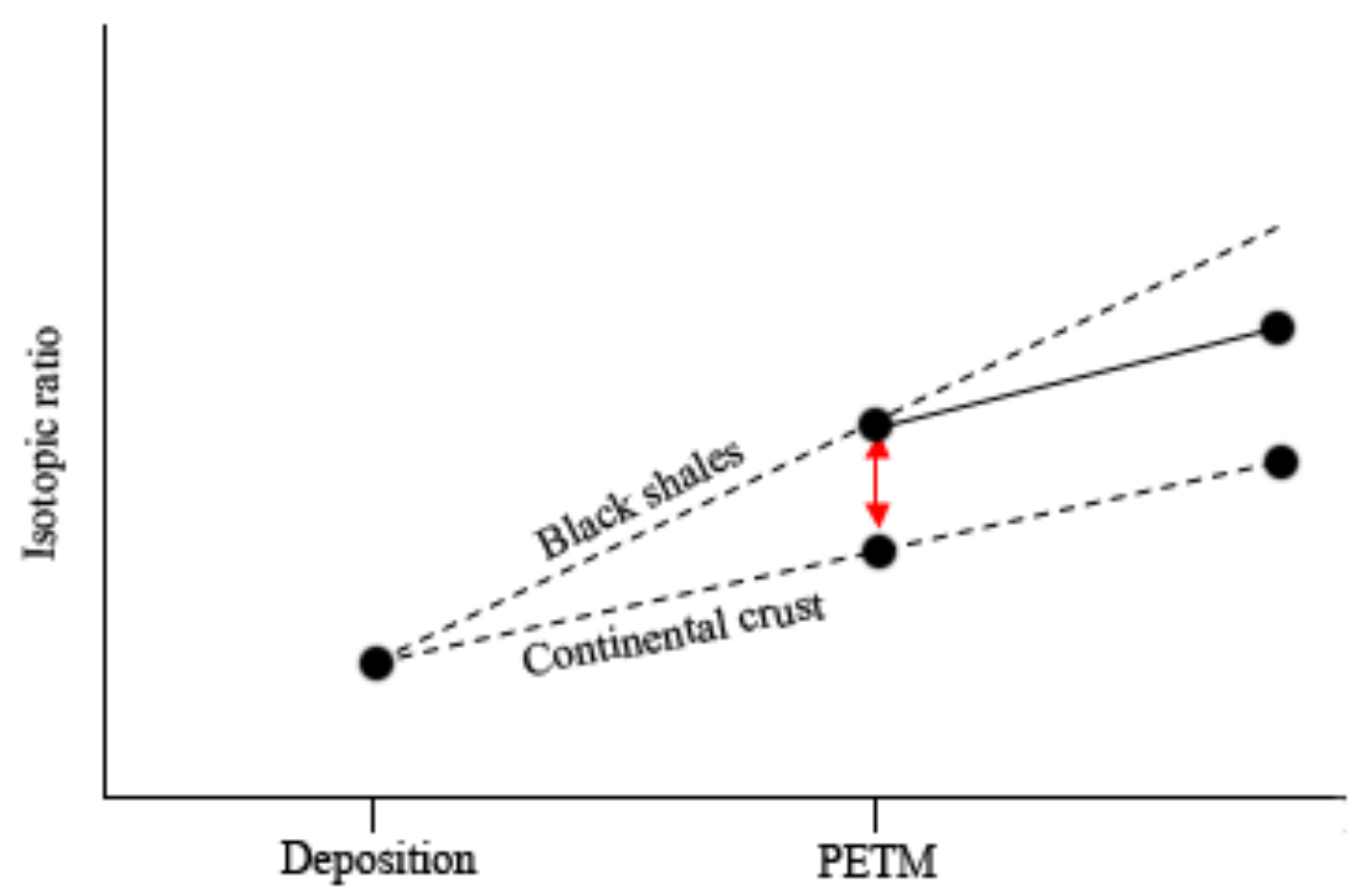

Time

Figure 1.4 Conceptual model of the evolution of the Re-Os system and the U-Th-Pb systems. The y-axis represents the isotope ratios ${ }^{187} \mathrm{Os} /{ }^{188} \mathrm{Os},{ }^{206} \mathrm{~Pb} /{ }^{204} \mathrm{~Pb}$, and ${ }^{207} \mathrm{~Pb} /{ }^{204} \mathrm{~Pb}$ (but not ${ }^{208} \mathrm{~Pb} /{ }^{204} \mathrm{~Pb}$ ). Organic-rich sediments are enriched in $\mathrm{U}$ and $\mathrm{Re}$, but not $\mathrm{Th}$, at the time of deposition relative to oxic marine sediments (average continental crust). The ingrowth trajectories (top dotted line) of radiogenic isotopes from $\mathrm{U}$ and Re decay are therefore steeper than the trajectory of average continental crust (bottom dotted line). At the PETM, the organicrich sediments are metamorphosed and release an unknown fraction of their radiogenic, volatile $\mathrm{Os}$ and $\mathrm{Pb}$ inventories to the ocean-atmosphere system. The red arrow indicates the isotopic difference between typical continental crustal sediments and the isotopic ratios of the $\mathrm{Pb}$ and $\mathrm{Os}$ of contemporaneous organic-rich sediments (see Fig. 1.5 for quantitative estimates). This isotope anomaly is a function of the difference in $\mathrm{U} / \mathrm{Pb}$ and $\mathrm{Re} / \mathrm{Os}$ between organic-rich sediments and average continental crust, and the time interval between the deposition of the 
source rocks and the metamorphic event at the PETM. Once separated from their source rocks, the $\mathrm{Pb}$ and $\mathrm{Os}$ mix with the surrounding seawater and are redeposited into oxic sediments (e.g. DSDP Site 549). The ingrowth trajectories of oxic sediments deposited during the PETM follow trajectories more typical of average continental crust (solid black line). Note that ${ }^{208} \mathrm{~Pb} /{ }^{204} \mathrm{~Pb}$ ingrowth trajectories for organic-rich sediments are identical to average continental crust, because organic-rich sediments are not enriched in Th over continental crust. 


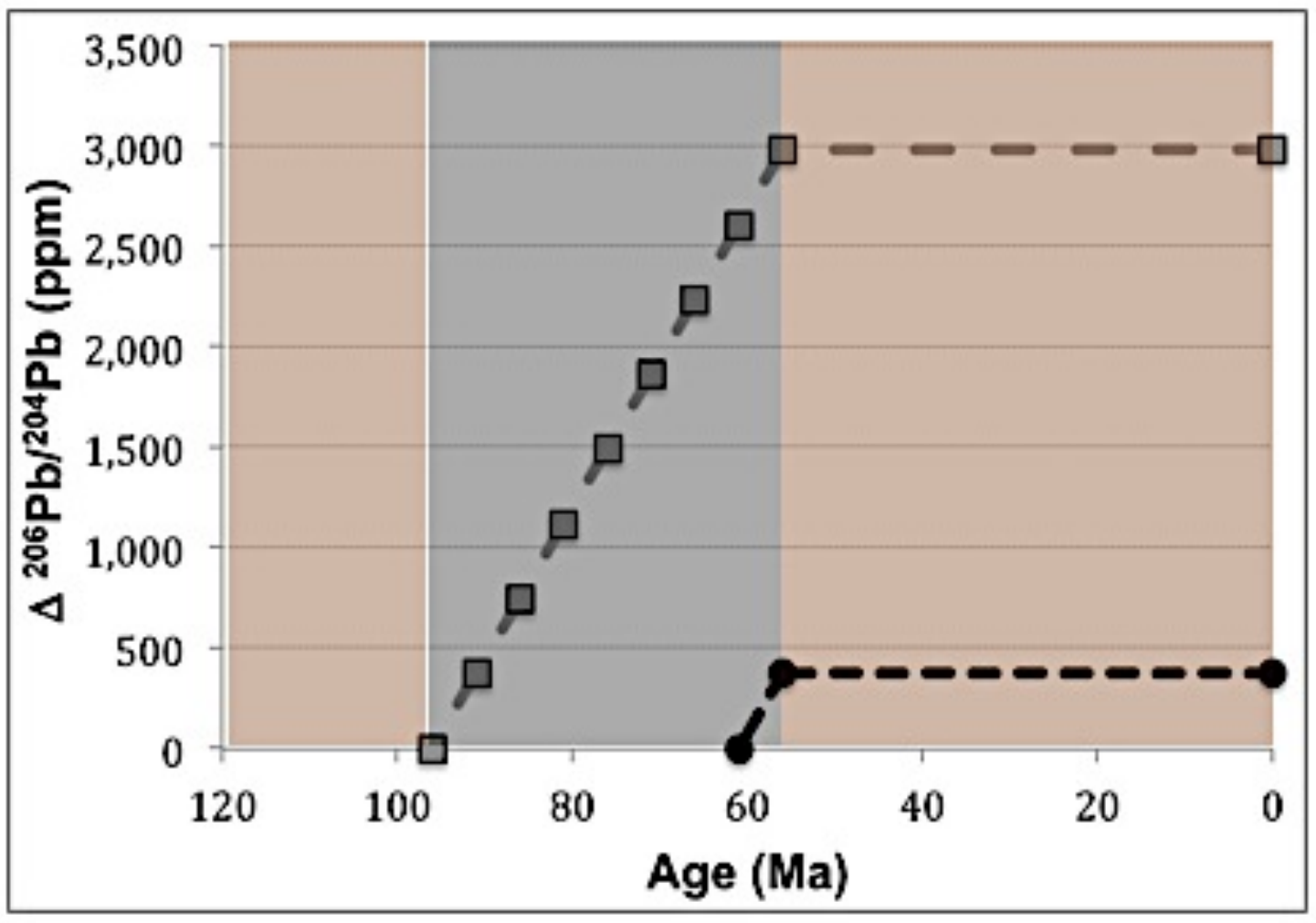

Figure 1.5 Examples of two ingrowth trajectories of organic-rich sediments deposited 40 and 5 million years prior to the PETM (56 Ma). The y-axis shows the magnitude (in parts per million, ppm) of the ${ }^{206} \mathrm{~Pb} /{ }^{204} \mathrm{~Pb}$ anomaly if $10 \%$ of the lead in PETM sediments is derived from aged organic-rich sediments (see text for details). The limit of analytical detection ( 2 s.d. external reproducibility) is $\sim \Delta=80 \mathrm{ppm}$ (Hart and Ball, 2004). Brown background color indicates evolution of the isotope systems under oxic conditions, whereas gray background color indicates evolution under reducing conditions with low $\mathrm{Th} / \mathrm{U}$ and high $\mathrm{U} / \mathrm{Pb}$. 


\subsection{References}

Beaulieu, E., Godderis, Y., Donnadieu, Y., Labat, D., Roelandt, C., 2012. High sensitivity of the continental-weathering carbon dioxide sink to future climate change. Nature Climate Change, doi: 10.1038/NCLIMATE1419.

Bralower, T.J., Zachos, J.C., Thomas, E., Parrow, M., Paull, C.K., Kelly, D.C., Silva, I.P., Sliter, W.V., Lohmann, K.C., 1995. Late Paleocene to Eocene paleoceanography of the equatorial Pacific-Ocean - stable isotopes recorded at Ocean Drilling Program Site-865, Allison-Guyot. Paleoceanography 10, 841-865.

Bralower, T.J., Thomas, D.J., Zachos, J.C., Hirschmann, M.M., Röhl, U., Signurdsson, H., Thomas, E., Whitney, D.L., 1997. High-resolution records of the late Paleocene thermal maximum and circum-Carribbean volcanism: Is there a causal link? Geology 25, 963-966.

Carozza, D.A., Mysak, L.A., Schmidt, G.A., 2011. Methane and environmental change during the Paleocene-Eocene thermal maximum (PETM): Modeling the PETM onset as a two-stage event. Geophysical Research Letters 38, DOI: 10.1029/2010GL046038.

Carpentier, M., Weis, D., Chauvel, C., 2013. Large U loss during weathering of upper continental crust: the sedimentary record. Chemical Geology 340, 91-104.

Chun, C.O.J., Delaney, M.L., Zachos, J.C., 2010. Paleoredox changes across the PaleoceneEocene thermal maximum, Walvis Ridge (ODP Sites 1262, 1263, and 1266): Evidence from Mn and U enrichment factors. Paleoceanography 25, DOI: 10.1029/2009PA001861.

Cooper, J.R., 2006. Igneous intrusion and thermal evolution in the Raton Basin, CO-NM: Contact metamorphism and coal-bed methane generation. MS thesis, University of MissouriColumbia, 249 pages.

Cooper, J.R., Crelling, J.C., Rimmer, S.M., Whittington, A.G., 2007. Coal metamorphism by igneous intrusion in the Raton Basin, $\mathrm{CO}$ and NM: Implications for generation of volatiles. International Journal of Coal Geology 71, 15-27.

DeConto, R.M., Galeotti, S., Pagani, M., Tracy, D., Schaefer, K., Zhang, T.J., Pollard, D., Beerling, D.J., 2012. Past extreme warming events linked to massive carbon release from thawing permafrost. Nature 484, DOI: 10.1038/nature10929.

Dickens, G.R., 2003. Rethinking the global carbon cycle with a large, dynamic and microbially mediated gas hydrate capacitor. Earth and Planetary Science Letters 213, 169-183.

Dickens, G.R., 2004. Hydrocarbon-driven warming. Nature 429, 513-514.

Dickens, G.R., 2011. Down the Rabbit Hole: toward appropriate discussion of methane release from gas hydrate systems during the Paleocene-Eocene thermal maximum and other past hyperthermal events. Climate of the Past 7, 831-846. 
Dickens, G.R., Francis, J.M., 2004. Comment on 'A case for a comet impact trigger for the Paleocene/Eocene thermal maximum and carbon isotope excursion'. Earth and Planetary Science Letters 217, 197-200.

Dickens, G.R., O’Neil, J.R., Rea, D.K., Owen, R.M., 1995. Dissociation of oceanic methane hydrate as a cause of the carbon isotope excursion at the end of the Paleocene.

Palaeoceanography 10, 965-971.

Dickens, G.R., Castillo, M.M., Walker, J.C.G., 1997. A blast of gas in the latest Paleocene: Simulating first-order effects of massive dissociation of oceanic methane hydrate. Geology 25, 259-262.

Ebelmen, J.J., 1845. Sur les produits de la dècomposition des especes minérales de la famille des silicates. Annales Des Mines 7, 3-66.

Farley, K.A., Eltgroth, S.F., 2003. An alternative age model for the Paleocene-Eocene thermal maximum using extraterrestrial He-3. Earth and Planetary Science Letters 208, 135-148.

Galeotti, S., Krishnan, S., Pagani, M., Lanci, L., Gaudio, A., Zachos, J.C., Monechi, S., Morelli, G., Lourens, L., 2010. Orbital chronology of Early Eocene hyperthermals from the Contessa Road section, central Italy. Earth and Planetary Science Letters 290, 192-200.

Galer, S.J.G., Goldstein, S.L.,1996. Influence of accretion on lead in the Earth. Influence of accretion on lead in the Earth. In: Earth Processes: Reading the isotopic code. Basu, A., Hart, S. (Eds.), AGU, Washington D.C.. 75-98.

Gradstein, F.M., Ogg, J.G., Schmitz, M.D., Ogg, G.M., Eds., 2012. The Geological Time Scale 2012, Amsterdam, Elsevier, 2 vols., 1144 p.

Handley, L., Crouch, E.M., Pancost, R.D., 2011. A New Zealand record of sea level rise and environmental change during the Paleoccene-Eocene Thermal Maximum. Palaeogeography, Palaeoclimatology, Palaeoecology 305, 185-200.

Harding, I.C., Charles, A.J., Marshall, J.E., Palike, H., Roberts, A.P., Wilson, P.A., Jarvis, E., Thorne, R., Morris, E., Moremon, R., Pearce, R.B., Akbari, S., 2011. Sea-level and salinity fluctuations during the Paleocene-Eocene thermal maximum in Arctic Spitsbergen. Earth and Planetary Science Letters 303, 97-107.

Hart, S.R., Ball, L., 2004. Isotopic homogeneity of the SRM981 Pb isotopic standard. WHOI Plasma Facility Open File Report 12, June, 2004.

Higgins, J.A., Schrag, D.P., 2006. Beyond methane: Towards a theory for the Paleocene-Eocene Thermal Maximum. Earth and Planetary Science Letters 245, 523-537. 
Hönisch, B., Ridgwell, A., Schmidt, D.N., Thomas, E., Gibbs, S.J., Sluijs, A., Zeebe, R., Kump, L., Martindale, R.C., Greene, S.E., Kiessling, W., Ries, J., Zachos, J.C., Royer, D.L., Barker, S., Marchitto, T.M., Moyer, R., Pelejero, C., Ziveri, P., Foster, G.L., Williams, B., 2012. The geological record of ocean acidification, Science 335, 1058-1063.

Katz, M.E., Cramer, B.S., Mountain, G.S., Katz, S., Miller, K.G., 2001. Uncorking the bottle: What triggered the Paleocene/Eocene thermal maximum methane release? Paleoceanography $16,549-562$.

Katz, M.E., Pak, D.K., Dickens, G.R., Miller, K.G., 1999. The source and fate of massive carbon input during the latest Paleocene thermal maximum. Science 286, 1531-1533.

Kennett, J.P., Stott, L.D., 1991. Abrupt deep-sea warming, palaeoceanographic changes and benthic extinctions at the end of the Palaeocene. Nature 353, 225-229.

Kent, D.V., Cramer, B.S., Lanci, L., Wang, D., Wright, J.D., Van der Voo, R., 2003. A case for a comet impact trigger for the Paleocene/Eocene thermal maximum and carbon isotope excursion, Earth and Planetary Science Letters 211, 13-26.

Kopp, R.E., Raub, T.D., Schumann, D., Vali, H., Smirnov, A.V., Kirschvink, J.L., 2007. Magnetofossil spike during the Paleocene-Eocene thermal maximum: Ferromagnetic resonance, rock magnetic and electron microscopy evidence from Ancora, New Jersey, United States. Paleoceanography 22, DOI: 10.1029/2007PA001473.

Kump, L.R., Brantley, S.L., Arthur, M.A., 2000. Chemical weathering, atmospheric $\mathrm{CO}_{2}$, and climate. Annual Review of Earth and Planetary Sciences 28, 611-667.

Kurtz, A.C., Kump, L.R., Arthur, M.A., Zachos, J.C., Paytan, A., 2003. Early Cenozoic decoupling of the global carbon and sulfur cycles. Paleoceanography 18 (4), DOI: 10.1029/2003PA000908.

Ledevin, M., 2010. Interaction magma-sédiment et impact environmental d'une intrusion doléritique, Antrim, Irlande du Nord. Rapport Master 2 Recherch - Terre Solide, OSUG, Universite Joseph Fourier, 49 pages.

Ledevin, M., Arndt, N., Cooper, M.R., Earls, G., Lyle, P., Aubourg, C., Levin, E., 2012. Intrusion history of the Portrush Sill, County Antrim, Northern Ireland: evidence for rapid emplacement and high-temperature contact metamorphism. Geological Magazine 149, 67-79.

Lippert, P.C., Zachos, J.C., 2007. A biogenic origin for anomalous fine-grained magnetic material at the Paleocene-Eocene boundary at Wilson Lake, New Jersey. Paleoceanography 22, DOI: $10.1029 / 2007$ PA001471.

Littler, K., Röhl, U., Westerhold, T., Zachos, J.C., 2014. A high-resolution benthic stableisotope record for the South Atlantic: Implications for orbital-scale changes in Late PaleoceneEarly Eocene climate and carbon cycling. Earth and Planetary Science Letters 401, 18-30. 
Lourens, L.J., Sluijs, A., Kroon, D., Zachos, J.C., Thomas, E., Röhl, U., Bowles, J., Raffi, I., 2005. Astronomical pacing of late Palaeocene to early Eocene global warming events. Nature 435, 1083-1087.

McInerney, F.A., Wing, S.L., 2011. The Paleocene-Eocene Thermal Maximum: A perturbation of carbon cycle, climate, and biosphere with implications for the future. Annual Review of Earth and Planetary Sciences 39, 489-516.

McLennan, S.M., 2001. Relationships between the trace element composition of sedimentary rocks and upper continental crust. Geochemistry, Geophysics, Geosystems 2, paper number 2000GC00109.

Nicolo, M.J., Dickens, G.R., Hollis, C.J., Zachos, J.C., 2007. Multiple early Eocene hyperthermals: Their sedimentary expression on the New Zealand continental margin and in the deep sea. Geology 35, 699-702.

Norris, R.D., Röhl, U., 1999. Carbon cycling and chronology of climate warming during the Palaeocene/Eocene transition. Nature 401, 775-778.

Moore, E.A., Kurtz, A.C., 2008. Black carbon in Paleocene-Eocene boundary sediments: A test of biomass combustion as the PETM trigger. Palaeogeography, Palaeoclimatology, Palaeoecology 267, 147-152.

Nunes, F., Norris, R.D., 2006. Abrupt reversal in ocean overturning during the Palaeocene/Eocene warm period. Nature 439, 60-63.

Pagani, M., Caldeira, K., Archer, D., Zachos, J.C., 2006. An ancient carbon mystery. Science 314, 1556-1557.

Page, S.E., Rieley, J.O., Banks, C.J., 2011. Global and regional importance of the tropical peatland carbon pool. Global Change Biology 17, 798-818.

Panchuk, K., Ridgwell, A., Kump, L.R., 2008. Sedimentary response to Paleocene-Eocene Thermal Maximum carbon release: A model-data comparison. Geology 36, 315-318.

Patterson, M.V., Francis, D., 2013. Kimberlite eruptions as triggers for early Cenozoic hyperthermals. Geochemistry, Geophysics, Geosystems 14 (2), DOI: 10.1002/ggge.20054.

Paytan, A., Kastner, M., Campbell, D., Thiemens, M.H., 1998. Sulfur Isotopic Composition of Cenozoic Seawater Sulfate. Science 282, 1459-1462.

Pegram, W.J., Turekian, K.K., 1999. The osmium isotopic composition change of Cenozoic sea water as inferred from a deep-sea core corrected for meteoric contributions. Geochimica et Cosmochimica Acta 63, 4053-4058. 
Peucker-Ehrenbrink, B., Ravizza, G.E., Hofmann, A.W., 1995. The marine ${ }^{187}$ Os $/{ }^{186}$ Os record of the past 80 million years. Earth and Planetary Science Letters 130, 155-167.

Peucker-Ehrenbrink, B., Ravizza, G., 2000. The marine osmium isotope record. Terra Nova 5, 12, 205-219.

Peucker-Ehrenbrink, B., Ravizza, G., 2012. Osmium Isotope Stratigraphy. In: The Geologic Time Scale 2012. (F.M. Gradstein, J.G. Ogg, M.D. Schmitz, G.M. Ogg, Eds.), Elsevier, Oxford, UK, 23 pp.

Ravizza G., Norris, R.N., Blusztajn, J., Aubry, M.-P., 2001. An osmium isotope excursion associated with the late Paleocene thermal maximum: Evidence of intensified chemical weathering. Paleoceanography 16, 155-163.

Rubey, W.W., 1951. Geologic history of sea water. An attempt to state the problem. Geological Society of America Bulletin 62, 1111-1148.

Schmitz, B., Peucker-Ehrenbrink, B., Heilmann-Clausen, C., Aberg, G., Asaro, F., Lee, C.-T.A., 2004. Basaltic explosive volcanism, but no comet impact, at the Paleocene-Eocene boundary; high-resolution chemical and isotopic records from Egypt, Spain, and Denmark. Earth and Planetary Science Letters 225, 1-17.

Schmitz, B., Pujalte, V., 2003. Sea-level, humidity, and land-erosion records across the initial Eocene thermal maximum from a continental-marine transect in northern Spain, Geology 31, 689-692.

Sluijs, A., Schouten, S., Pagani, M., Woltering, M., Brinkhuis, H., Damste, J.S.S., Dickens, G.R., Huber, M., Reichart, G.J., Stein, R., 2006. Subtropical Arctic Ocean temperatures during the Palaeocene/Eocene thermal maximum. Nature 441, 610-613.

Sluijs, A., Brinkhuis, H., Schouten, S., Bohaty, S.M., John, C.M., Zachos, J.C., Reichart, G.J., Damste, J.S.S., Crouch, E.M., Dickens, G.R., 2007. Environmental precursors to rapid light carbon injection at the Palaeocene/Eocene boundary, Nature 450, DOI: 10.1038/nature06400.

Sluijs, A., Brinkhuis, H., Crouch, E.M., John, C.J., Handley, L., Munsterman, D., Bohaty, S.M., Zachos, J.C., Reichart, G.J., Schouten, S., Pancost, R.D., Sinninghe Damste, J.S., Welters, N.L.D., Lotter, A.F., Dickens, G.R., 2008. Eustatic variations during the Palaeocene-Eocene greenhouse world. Paleocenography 23, DOI: 10.1029/2008PA001615.

Smith, F.A., Wing, S.L., Freeman, K.H., 2007. Magnitude of the carbon isotope excursion at the Paleocene-Eocene Thermal Maximum: the role of plant community change. Earth and Planetary Science Letters 262, 50-65.

Storey, M., Duncan, R.A., Swisher, C.C., 2007. Paleocene-Eocene thermal maximum and the opening of the northeast Atlantic. Science 316, 587-589. 
Svensen, H, Planke, S., Melthe-Sørenssen, A., Jamtveit, B., Myklebust, R., Rasmussen Eidem, T., Rey, S.S., 2004. Release of methane from a volcanic basin as a mechanism for initial Eocene global warming. Nature 429, 542-545.

Svensen, H., Planke, S., Corfu, F., 2010. Zircon dating ties NE Atlantic sill emplacement to initial Eocene global warming. Journal of the Geological Society 167, 433-436.

Taylor, S.R., McLennan, S.M., 1985. The Continental Crust: Its Composition and Evolution. Blackwell Science, Malden, Mass. 312 pp.

Thomas, E., Shackleton, N.J., 1996. The Paleocene-Eocene benthic foraminiferal extinction and stable isotope anomalies. Geological Society London Special Publications 101, 401-441.

Thomas, D.J., Zachos, J.C., Bralower, T.J., Thomas, E., Boharty, S., 2002. Warming the fuel for the fire: Evidence for the thermal dissociation of methane hydrate during the Paleocene-Eocene thermal maximum. Geology 30, 1067-1070.

Tipple, B.J., Pagani, M., Krishnan, S., Dirghangi, S.S., Galeotti, S., Agnini, C., Giusberti, L., Rio, D., 2011. Coupled high-resolution marine and terrestrial records of carbon and hydrologic cycles variations during the Paleocene-Eocene Thermal Maximum (PETM). Earth and Planetary Science Letters 311, 82-92.

Tripati, A., Elderfield, H., 2005. Deep-sea temperature and circulation changes at the PaleoceneEocene Thermal Maximum. Science 308, 1894-1898.

Villasante-Marcos, V., Hollis, C.J., Dickens, G.R., Nicolo, M.J., 2009. Rock magnetic properties across the Paleocene-Eocene Thermal Maximum in Marlborough New Zealand. Geologica Acta 7, 229-242.

Walker, J.C.G., Hays, P.B., Kasting, J.F., 1981. A negative feedback mechanism for the longterm stabilization of Earth's surface temperature. Journal of Geophysical Research 86, 97769782.

Westerhold, T., Röhl, U., McCarren, H.K., Zachos, J.C., 2009. Latest on the absolute age of the Paleocene-Eocene Thermal Maximum (PETM): new insights from exact stratigraphic position of key ash layers +19 and -17. Earth and Planetary Science Letters 287, 412-419.

Wright, J.D., Schaller, M.F., 2013. Evidence for a rapid release of carbon at the PaleoceneEocene thermal maximum. Proceedings of the National Academy of Sciences 110, 15908-15913.

Zachos, J.C., Pagani, M., Sloan, L., Thomas, E., Billups, K., 2001. Trends, rhythms, and aberrations in global climate 65 Ma to Present. Science 292, 686-693.

Zachos, J.C., Dickens, G.R., Zeebe, R.E., 2008. An early Cenozoic perspective on greenhouse warming and carbon-cycle dynamics. Nature 451, 279-283. 
Zachos, J.C., Röhl, U., Schellenberg, S.A., Sluijs, A., Hodell, D.A., Kelly, D.C., Thomas, E., Nicolo, M., Raffi, I., Lourens, L.J., McCarren, H., Kroon, D., 2005. Rapid acidification of the ocean during the Paleocene-Eocene thermal maximum. Science 308, 1611-1615.

Zachos, J.C., McCarren, H., Murphy, B., Röhl, U., Westerhold, T., 2010. Tempo and scale of late Paleocene and early Eocene carbon isotope cycles: Implications for the origin of hyperthermals. Earth and Planetary Science Letters 299, 242-249.

Zeebe, R.E., Zachos, J.C., Dickens, G.R., 2009. Carbon dioxide forcing alone insufficient to explain Paleocene-Eocene Thermal Maximum warming. Nature Geoscience 2, 576-580. 


\section{CHAPTER 2.}

\section{The importance of organic-rich shales to the geochemical cycles of rhenium and osmium}

Published as:

Dubin, A., Peucker-Ehrenbrink, B., 2015. The importance of organic-rich shales to the geochemical cycles of rhenium and osmium. Chemical Geology DOI:

10.1016/j.chemgeo.2015.03.010.

Reproduced with permission from Elsevier.

\subsection{Abstract}

The role that marine organic-rich sediments play in the surficial osmium and rhenium cycles has been assumed to be important due to the high Re/Os ratios and high concentrations of these elements in such reducing sediments compared to the average continental crust. The high $\mathrm{Re} /$ Os leads to rapidly increasing ${ }^{187} \mathrm{Os} /{ }^{188}$ Os ratios. We determine how large a role these sediments play in the surficial osmium and rhenium budgets by compiling a geochemical database to quantify the mean ${ }^{187} \mathrm{Re} /{ }^{188} \mathrm{Os}$ and ${ }^{187} \mathrm{Os} /{ }^{188} \mathrm{Os}$ ratios of organic-rich sediments. We then utilize estimates of the abundance of organic-rich sediments in the geologic record of different ages to estimate an average ${ }^{187} \mathrm{Os} /{ }^{188}$ Os for these sediments. We find that the calculated ${ }^{187} \mathrm{Os} /{ }^{188} \mathrm{Os}$ value of organic-rich sediments varies between 2.22 and 2.27 depending on the volume-age model used, with error estimates of 2.07 to 2.42 and 2.12 to 2.48 , respectively. Despite the fact that these sediments constitute a relatively small proportion of the upper continental crust, they contribute a disproportionately large amount $(>50 \%)$ to the upper 
continental crustal rhenium and, to a lesser extent (5-10\%), osmium inventories owing to their high concentrations of these elements.

\subsection{Introduction}

Osmium (Os) is a dense platinum group element whose highly siderophile and chalcophile properties make it behave compatibly during mantle melting and lead to its concentration in the earth's core (Goldschmidt, 1922), making it one of the rarest elements in the earth's crust (e.g. Esser and Turekian, 1993). This is reflected in the ratio of Os mass between the earth's mantle and the continental and oceanic crusts of $\sim 2 \times 10^{4} / 1$ (Ahrens, 1995; Allègre et al., 2001; Esser and Turekian, 1993; Schmidt and Palme, 1997). Variations in ${ }^{187}$ Os $/{ }^{188}$ Os that characterize these reservoirs are caused by the $\beta$-decay of ${ }^{187} \operatorname{Re}$ to ${ }^{187}$ Os with a half-life of 41.6 Gy (Smoliar et al., 1996) and reflect time-integrated changes in the rhenium (Re) to Os concentration ratios.

In contrast to Os, Re is a moderately incompatible element whose enrichment ratio between the earth's mantle and the crust of $\sim 2 \times 10^{2} / 1$ is much less pronounced (Ahrens, 1995; Allègre et al., 2001; Esser and Turekian, 1993; Schmidt and Palme, 1997; Ahrens, 1995). While on average the continental crust has low Os concentrations, small exposures of mantle-derived rocks (e.g. ophiolites) and enrichment processes at the earth's surface can lead to crustal reservoirs with very unusual geochemical characteristics that may exert disproportionate influences on the cycling of Os and Re near the earth's surface. Among those reservoirs are sulfide minerals (e.g. molybenites; Miller et al, 2011; Noddack and Noddack, 1931; Suzuki et al., 1993) and marine sediments with high organic carbon contents that were deposited under reducing conditions (e.g. Cohen et al., 1999; Colodner et al., 1993; Ravizza and Turekian, 1989; Ravizza et al., 1991; Selby and Creaser, 2003). Both Re and Os occur in multiple redox states at 
the earth's surface and are sensitive to changes in redox condition (Yamashita et al., 2007). Under oxic conditions, both elements, but particularly Re, are very soluble in natural waters and behave conservatively (Anbar et al., 1992; Colodner et al., 1993). Seawater, for instance, has a Re/Os concentration ratio of $\sim 4200$ (Peucker-Ehrenbrink and Ravizza, 2000). In reducing environments, however, Re and Os are much less soluble and become enriched in marine sediments, and their concentrations correlate with organic carbon content (Cohen et al., 1999; Crusius et al., 1996; Horan et al., 1994; Koide et al., 1986; 1991; Ravizza et al., 1991; Ravizza and Turekian, 1989, 1992). Rhenium in particular is often found to be the most enriched redoxsensitive trace element compared to detrital background concentrations (Crusius and Thomson, 2000; Morford and Emerson, 1999).

Cycling of organic-rich sediments between marine and terrestrial environments is generally viewed as an important source of Re and radiogenic Os to seawater (e.g., Hilton et al., 2014; Jaffe et al., 2002; Peucker-Ehrenbrink and Blum, 1998; Peucker-Ehrenbrink and Hannigan, 2000; Peucker-Ehrenbrink and Ravizza, 2000; Pierson-Wickmann et al., 2000; Ravizza and Esser, 1993; Singh et al., 1999). Temporal variations in the ${ }^{187} \mathrm{Os} /{ }^{188} \mathrm{Os}$ of seawater reflect changes in earth surface processes and the transfer of Os from terrestrial or submarine to marine environments (Dalai et al., 2005; Levasseur et al., 2000; Pegram et al., 1992; Ravizza et al., 1996; Sharma et al., 1997). The Os hosted in organic-rich sediments is much more readily mobilized during weathering than the Os in typical granitoid upper crustal rocks (Jaffe et al., 2002; Peucker-Ehrenbrink and Blum, 1998; Peucker-Ehrenbrink and Hannigan, 2000; PiersonWickmann et al., 2002). The unusual geochemical characteristics of organic-rich sediments led Peucker-Ehrenbrink and Ravizza (2000) to argue that steady-state cycling of such sediments is capable of driving the Cenozoic evolution of the ${ }^{187} \mathrm{Os} /{ }^{188} \mathrm{Os}$ of seawater from less radiogenic 
values in the early Cenozoic to the radiogenic values observed today. In this interpretation of the marine ${ }^{187} \mathrm{Os} /{ }^{188} \mathrm{Os}$ record, increasing ${ }^{187} \mathrm{Os} /{ }^{188} \mathrm{Os}$ values of seawater throughout the Cenozoic may not reflect increasing continental inputs of Os, or decreasing mantle-derived fluxes, but simply the steady cycling of comparatively radiogenic organic-rich sediments.

The large ranges in ${ }^{187} \mathrm{Re}^{1 / 88} \mathrm{Os}$ as well as Re and Os concentrations in rocks and minerals exposed at the earth surface pose the question of which terrestrial sources of Os exert the largest influence on the seawater budget. The global significance of organic-rich sediments in the cycling of Re and Os, however, is very difficult to assess, because the volumetric proportion of this reservoir as part of the upper continental crust (UCC) is unknown. To overcome this limitation, we develop a conceptual model that aims at constraining the importance of such sediments for the near-surface Re and Os cycles.

Our approach to this problem is performed in five stages. First, we compile a geochemical database of organic-rich sediments using data from the literature. Second, we use this database to calculate reasonable averages and uncertainties of ${ }^{187} \mathrm{Os} /{ }^{188} \mathrm{Os}$ for sediments of different ages. Third, we estimate the abundance of organic-rich sediments in the geologic record through time, and integrate the time-area, time-volume, or time-mass curves using the average ${ }^{187} \mathrm{Re} /{ }^{188} \mathrm{Os}$ values from the geochemical database as well as reasonable estimates for initial ${ }^{187} \mathrm{Os} /{ }^{188} \mathrm{Os}$ from the marine ${ }^{187} \mathrm{Os} /{ }^{188} \mathrm{Os}$ record. This produces an estimate of the average value and uncertainty of ${ }^{187} \mathrm{Os} /{ }^{188} \mathrm{Os}$ for marine organic-rich sediments. Fourth, we use typical Os and Re concentrations to determine what fraction of upper crustal Re and Os are hosted in organic-rich sediments. Finally, we compare the results for organic-rich sediment to typical UCC to estimate the impact these sediments have on the near-surface cycles of Re and Os. 


\subsection{Data sources and modeling methodology}

\subsubsection{Geochemical database of Re-Os-TOC concentrations in organic-rich sediments}

A geochemical database of Re and Os concentrations, ${ }^{187} \mathrm{Os} /{ }^{188} \mathrm{Os}$, total organic carbon (TOC) concentrations, and sediment ages was compiled from the literature, incorporating 1006 data points of sediments from 42 different literature sources. The database encompasses sediments with TOC concentrations ranging from 0.01 to 74.9 wt.\%. For samples that have Re and Os concentrations and ${ }^{187} \mathrm{Os} /{ }^{188} \mathrm{Os}$ values reported but lack information on either ${ }^{187} \mathrm{Re} /{ }^{188} \mathrm{Os}$ or initial ${ }^{187} \mathrm{Os} /{ }^{188} \mathrm{Os}$, these values were calculated. The initial ${ }^{187} \mathrm{Os} /{ }^{188} \mathrm{Os}$ was calculated using the sample age and assuming the original ${ }^{187} \mathrm{Re} /{ }^{188} \mathrm{Os}$ remained unperturbed. The database was first filtered to remove any data points with incomplete information. 715 data points were excluded due to a lack of reported TOC values. An additional 14 data points had no Re data reported and were similarly discarded. Next the database was filtered to remove those data points that are not representative of typical marine organic-rich sediments. We focus on organicrich sediments with TOC concentrations between 0.5 and 20 wt.\%. Sediments with TOC concentrations below $0.5 \mathrm{wt} \%$ (24 data points) are not sufficiently enriched in organic matter relative to other marine sediments, and likely lack depositional characteristics that lead to enrichment of redox-sensitive elements. Samples with TOC concentrations above 20 wt.\% (22 data points) are likely affected by post-depositional alteration, and are considered separately in order to evaluate what effect the inclusion of such unusual, and likely rare, sediments has on the average values. An additional 66 samples were removed that were deposited in non-marine or unknown environments. Of the remaining 165 entries, 9 were duplicate analyses of another entry and were removed from the database so as not to skew the overall average. The final database consists of 156 entries (Table 1). 
Increasing ${ }^{187} \mathrm{Re} /{ }^{188} \mathrm{Os}$ values are loosely correlated with increasing TOC concentrations $\left(\mathrm{R}^{2}=0.27\right.$ ) with regression coefficients $\mathrm{m}_{1}=57.7$ and $\mathrm{m}_{2}=230$ (where $\mathrm{m}_{1}$ is the slope and $\mathrm{m}_{2}$ is the intercept) and standard errors of 7.6 and 60 respectively, using a least squares linear regression on the filtered database (Figure 1). We expected the correlation with organic carbon to be stronger, as Re enrichment over Os - compared to average detrital sediments - typically occurs under suboxic to highly reducing conditions under which organic matter preservation is high (Georgiev et al., 2011; Morford and Emerson, 1999; Peucker-Ehrenbrink and Ravizza, 2000; Yamashita et al., 2007). However, other factors such as Re and Os abundances in the water column (Turgeon et al., 2007), sedimentation rate (Crusius and Thomson, 2000; Lewan and Maynard, 1982), salinity, pH, temperature (Georgiev et al., 2011; Martin et al., 2001), and post-depositional mobility (Crusius and Thomson, 2000; Kendall et al., 2009) may effect the ${ }^{187} \mathrm{Re}^{/ 188}$ Os of the sediments, reducing the correlation with TOC.

The ${ }^{187} \mathrm{Re} /{ }^{188} \mathrm{Os}$ values of the database have a sample mean of 605 and a median of 510 . The first quartile is 231 while the third quartile is 763 . As these values are used in subsequent calculations, we need to determine their uncertainties. We therefore investigate whether the ${ }^{187} \mathrm{Re} /{ }^{188}$ Os values follow theoretical normal or log-normal distributions. A Lilliefors test, which uses the population mean and variance to test whether the data might derive from a normally distributed population, was used and the null hypothesis is rejected at the 5\% significance level (Lilliefors, 1967, 1969). Instead, the values cluster at lower ${ }^{187} \mathrm{Re} /{ }^{188} \mathrm{Os}$ values with a long tail towards larger values (Figure 2). The observed skewed distribution is likely shaped by the, albeit weak, correlation with TOC. The database includes a disproportionately large number of samples with high TOC values, and correspondingly high ${ }^{187} \mathrm{Re} /{ }^{188} \mathrm{Os}$, which may not be representative of the majority of organic-rich sediments, the majority of which have much more 
moderate TOC values. In addition, the truncation of the low end of TOC concentration at 0.5 wt.\% also may affect the low end of the distribution of ${ }^{187} \mathrm{Re} /{ }^{188} \mathrm{Os}$. The sample data also are not log-normally distributed, again rejecting the null hypothesis using a Lilliefors test at the 5\% significance level.

Because the theoretical distribution of the data is unknown, estimates of the ${ }^{187} \mathrm{Re} /{ }^{188} \mathrm{Os}$ value and statistical error were determined using three different methods. The uncertainty on the mean was estimated using a bootstrapping method (Efron, 1979). The bootstrapping method takes a random sampling of the data set, with replacement, to estimate the parameters of a distribution including confidence intervals and error prediction. This method is useful when the theoretical distribution of a sample is unknown or cannot be determined. 10,000 bootstrap samples were taken using sampling with replacement from the filtered data set, and the sample mean of each bootstrap sample was calculated (Figure 3). The mean of all the bootstrap means remains 605 , with a standard deviation of 40 . The 95-percentile confidence interval on the mean is $(542,672)$. The mean ${ }^{187} \mathrm{Re} /{ }^{188}$ Os weighted by Os content was also calculated by summing the total molar ${ }^{187} \mathrm{Re}$ values of all samples in the database and dividing by the sum of the molar ${ }^{188}$ Os values. This yields a weighted mean ${ }^{187} \mathrm{Re} /{ }^{188} \mathrm{Os}$ of 480 . This lower value indicates that there is a bias towards samples with lower Os concentrations that are also characterized by lower ${ }^{187} \mathrm{Re} /{ }^{188}$ Os. As the theoretical distributions of ${ }^{187} \mathrm{Re}$ and ${ }^{188}$ Os are both unknown, a confidence interval is not well defined for this method of estimating ${ }^{187} \mathrm{Re} /{ }^{188}$ Os. Finally, an estimate of the ${ }^{187} \mathrm{Re} /{ }^{188}$ Os was obtained using the bootstrap algorithm on the median of the samples. The median is more resistant to outliers than the mean and is better defined when the original distribution is skewed or not Gaussian. Again using 10,000 bootstrap samples (with replacement), the mean of the bootstrapped medians is 517 with a 95-percentile confidence 
interval of $(468,582)$. For the remainder of this paper, the mean of the bootstrapped medians will be used, as it provides the best estimate of the ${ }^{187} \mathrm{Re}^{188}$ Os while still providing an estimate of the uncertainty (Brody et al., 2002). The confidence interval also encompasses the estimate from the weighted mean ${ }^{187} \mathrm{Re} /{ }^{188} \mathrm{Os}$.

The unfiltered database contains several samples with exceedingly high TOC concentrations (Figure 1). For example, Baioumy et al. (2011) present Re and Os data for coals with TOC concentrations exceeding $70 \mathrm{wt} . \%$. Including all unfiltered data points results in a very poor correlation between TOC and ${ }^{187} \mathrm{Re} /{ }^{188} \mathrm{Os}\left(\mathrm{R}^{2}=0.04\right)$ as well as a lower mean ${ }^{187} \mathrm{Re}^{188} \mathrm{Os}(338)$ and 95 -percentile confidence interval on the mean from bootstrapping (301, 398). As these samples have been severely altered after deposition, they were filtered out of the database and are not considered in the remainder of this paper. The mean TOC concentration of the remaining samples, listed in Table 1, is $6.5 \mathrm{wt} . \%$, with a 95-percentile confidence interval on the mean of $(5.9,7.1)$. The bootstrapped medians give a mean TOC concentration of 5.8 with a 95-percentile confidence interval of $(5.4,6.3)$.

\subsubsection{Organic-rich sediments in the geological record}

In an attempt to estimate the global significance of organic-rich sediments for the marine Re and Os budgets, we need data on the volume-age, mass-age, or area-age relationship of such sedimentary rocks in the geologic record. That is, we need to understand for a given age the volume, mass, or surface exposure of organic-rich sediments accessible to the modern surficial cycle. As this record does not exist, we use proxy data to constrain these relationships and discuss the strengths and weaknesses of each data set below.

The first data set we explore is the volume-age database by Cook and Bally (1975), hereafter abbreviated CB75, which represents a collection of data from approximately 
$18,178,000 \mathrm{~km}^{3}$ of shale. This database was created from drill holes in North and Central America by documenting the occurrence of major lithologic units and their stratigraphic ages. By mapping the areal extent of each lithostratigraphic unit defined by CB75, Berry and Wilkinson (1994) calculated volumetric abundances for each lithology (Figure 4a). Gray and black shale, a category not defined with respect to TOC content, comprise $29 \%$ of the total sedimentary volume in North and Central America. Berry and Wilkinson (1994) showed that the volumetric proportions of major sediment lithologies in North and Central America are reasonably similar to the world average (Ronov, 1980), with a slight overrepresentation of carbonates relative to terrigenous clastics. In contrast, Garrels and Mackenzie (1969) and Li (1972) estimate that "shale and clay" account for $74 \%$ and $71 \%$ of all sedimentary rocks, respectively. The discrepancy between "shale and clay" proportions estimated by Garrels and Mackenzie (1969) and Li (1972), and the estimate of 29\% for gray and black shales in North and Central America (Cook and Bally, 1975), most likely reflects the fact that gray and black shales included in the CB75 compilation are limited to sediments richer in organic matter and thus more similar to the sediments and sedimentary rocks in our compilation.

A second proxy data set is the $100 \mathrm{Myr}$ record of organic carbon burial by Li and Elderfield (2013), hereafter referred to as LE13, that is based on reverse modeling of the marine $\mathrm{C}, \mathrm{Sr}$, and Os isotope records, as well as records of seafloor spreading using mass balance equations and isotopic ratios (Figure $4 b$ ).

The CB75 and LE13 records show differing trends with some similarities, most notably the large peak at $80 \mathrm{Ma}$ (Figure 4). However, the magnitudes are significantly different, with the CB75 record showing a much larger relative proportion of organic carbon at around $80 \mathrm{Ma}$. Each record has a distinct set of strengths and weaknesses. The CB75 is limited to North and 
Central America and also extrapolates the volume of sediments over the entire continent from discrete points, i.e. drill cores. In addition, this record only includes sediments that have been preserved in the geologic record, and excludes sediments that have fallen victim to cannibalistic recycling (Goldstein, 1988; Wilkinson et al., 2009) or metamorphic overprint. The survival probability of sediments decreases according to a power law with time, with a half-life of approximately 100 Myr (Peucker-Ehrenbrink and Miller, 2007; Wilkinson et al., 2009). As decay of ${ }^{187} \mathrm{Re}$ in older shales has created higher ${ }^{187} \mathrm{Os} /{ }^{188} \mathrm{Os}$ values, subsequent loss of these shales skews the average ${ }^{187} \mathrm{Os} /{ }^{188}$ Os towards lower values. While the $\mathrm{CB} 75$ record has a low temporal resolution (on average 14.4 Myr), it provides the only complete Phanerozoic record.

The LE13 record does not distinguish between the types of sediments that the organic carbon is being deposited into, and therefore is not necessarily representative of the organic-rich shales that we are hoping to examine and that are represented in our database. The record estimates carbon burial without addressing preservation. In addition, while the temporal resolution of the LE13 model (0.5 Myr) is much higher than the CB75 record (on average 14.4 Myr), the CB75 record extends back much further (to $565 \mathrm{Ma}$ ).

Using the two models and the estimated ${ }^{187} \mathrm{Re}^{188}$ Os value of $517(95 \%$ confidence interval: 468 to 582 ) calculated from the geochemical database, the present-day ${ }^{187} \mathrm{Os} /{ }^{188} \mathrm{Os}$ values of shale from each age range can be determined from the radioactive decay equation. Calculations were made by dividing the timespan into bins averaging 14.4 Myr for the CB75 model and 0.5 Myr for the LE13 model, then the average ${ }^{187} \mathrm{Os} /{ }^{188} \mathrm{Os}$ value (calculated from the median ${ }^{187} \mathrm{Re} /{ }^{188} \mathrm{Os}$ and the seawater initial ${ }^{187} \mathrm{Os} /{ }^{188} \mathrm{Os}$ ) was weighted by the relative proportion of organic-rich shale in each age bin from the two models. As no data are available beyond 100 Ma for the LE13 model, older data were filled in using the CB75 record such that the models 
only differ after $100 \mathrm{Ma}$. Initial ${ }^{187} \mathrm{Os} /{ }^{188} \mathrm{Os}$ for organic-rich sediments younger than $100 \mathrm{Ma}$ were taken from the recent compilation of the marine seawater record (Peucker-Ehrenbrink and Ravizza, 2012). For older sediments, an average initial value of 0.6 , the average value from our geochemical database, was used.

\subsection{Results and discussion}

2.4.1 Average ${ }^{187} \mathrm{Os} /{ }^{188} \mathrm{OS}$

The weighted mean present-day ${ }^{187} \mathrm{Os} /{ }^{188} \mathrm{Os}$ of gray and black shales is 2.22 for the LE13 model and 2.27 for the CB75 volume-age record. The 95-percentile confidence intervals for the estimated ${ }^{187} \mathrm{Re} /{ }^{188} \mathrm{Os}$ yield modeled ${ }^{187} \mathrm{Os} /{ }^{188} \mathrm{Os}$ confidence intervals of 2.07 to 2.42 and 2.12 to 2.48 for these two models, respectively. The models produce very similar results for average ${ }^{187} \mathrm{Os} /{ }^{188} \mathrm{Os}$, although they differ for the past $100 \mathrm{Myr}$, a time interval representing about $40 \%$ of the sediments in the upper crust based on the CB75 model. Comparing the ${ }^{187} \mathrm{Os} /{ }^{188} \mathrm{Os}$ of the two records only after 100 Ma gives a value of 1.33 for the CB75 record and 1.13 for the LE13 model. The $95 \%$ confidence intervals on these values are $(1.27,1.41)$ and $(1.09,1.18)$ respectively. At this resolution, the models do differ significantly. The modeled values are significantly lower than the median measured ${ }^{187} \mathrm{Os} /{ }^{188} \mathrm{Os}$ values from the samples in the database (sample median of 2.42 with a bootstrapped 95-percentile confidence interval of 2.13 to 2.79).

\subsubsection{Organic-rich sediments in the upper crustal Re and Os budgets}

The above assessment allows us to determine the fractions of the crustal Re and Os inventories that are associated with organic-rich sediments. Estimates for average Re concentrations for the UCC range from about $200 \mathrm{pg} / \mathrm{g}$ to $2 \mathrm{ng} / \mathrm{g}$ (Esser and Turekian, 1993; 
Peucker-Ehrenbrink and Jahn, 2001; Schmidt et al., 1997; Sun et al., 2003; Taylor and McLennan, 1985). Assuming an average ${ }^{187} \mathrm{Os} /{ }^{188} \mathrm{Os}$ value of the upper continental crust of 1.4 (Peucker-Ehrenbrink and Jahn, 2001), an average age of the continental crust of $\sim 1.8 \mathrm{Gyr}$ (Jacobson and Wasserburg, 1979), and an initial ${ }^{187} \mathrm{Os} /{ }^{188} \mathrm{Os}$ of 0.12 based on the primitive mantle composition (Meisel et al., 1996) age-corrected to $1.8 \mathrm{Ga}$, the average ${ }^{187} \mathrm{Re} /{ }^{188} \mathrm{Os}$ of the upper continental crust is $\sim 42$. Assuming an average continental crustal Os concentration of 31 pg Os/g (Peucker-Ehrenbrink and Jahn, 2001) to 50 pg/g (Esser and Turekian, 1993), an average crustal Re concentration of $230 \mathrm{pg} / \mathrm{g}$ to $370 \mathrm{pg} / \mathrm{g}$ is calculated. This estimate compares favorably with values at the lower end of the order of magnitude estimates of crustal Re concentrations cited above. Compared to the median Re concentration of $35 \mathrm{ng} / \mathrm{g}$ with a bootstrapped $95-$ percentile confidence interval of 28 to $45 \mathrm{ng} / \mathrm{g}$ that characterize organic-rich sediments in our database, marine organic-rich sediments are much more enriched in Re relative to average UCC. Such sediments can only constitute a very small fraction of the upper continental crust.

While organic-rich sediments can only account for a small fraction of the UCC (Cook and Bally, 1975), their high Re and Os concentrations may cause them to contribute a disproportionately large fraction to the upper crustal Re and Os inventories. A simple mass balance calculation shows the effect. We assume that the Re concentration of the UCC is equal to the average crustal value $(270 \mathrm{pg} / \mathrm{g})$ and the average Re concentration in organic sediment is equal to the median Re concentration in marine shales in our compilation (35 ng/g, with a bootstrapped 95-percentile confidence interval of 28 to $45 \mathrm{ng} \mathrm{Re} / \mathrm{g}$ ). The black lines in Figure 5 show the percentage of the upper continental Re inventory that is hosted in organic-rich sediments, as defined above, as a function of the fraction of the UCC consisting of such sediments. It is clear that even small volumetric proportions of such sediments exert a strong 
influence on the crustal Re inventory. This finding is consistent with estimates by Colodner et al. (1993), Crusius and Thomson (2000) and Morford and Emerson (1999) that more than half of the upper crustal Re inventory is associated with suboxic and anoxic marine sediments. The mass balance calculation also limits the volumetric proportion of sediments as organic-rich as those in our database to less than $\sim 1$ percent. While the CB75 model indicates a much larger portion of UCC could be composed of gray or black shales, those sediments were likely not as rich in organic matter as those represented in our database.

Following the same approach, an average UCC Os concentration of $31 \mathrm{pg} / \mathrm{g}$ and an estimate of the organic-rich sediment Os concentration of $586 \mathrm{pg} / \mathrm{g}$ from the median in our database with bootstrapped 95-percentile confidence interval of $454 \mathrm{pg}$ Os/g to $705 \mathrm{pg} \mathrm{Os} / \mathrm{g}$ yields estimates represented by the red lines in Figure 5. A much smaller, yet still significant, fraction ( $\sim 10-20 \%)$ of the UCC Os inventory is tied up in such organic-rich sediments. This estimate is within the permissible limits of an isotope mass balance, as sediments with a ${ }^{187} \mathrm{Os} /{ }^{188} \mathrm{Os}$ of 2.53 could account for up to $53 \%$ of the average global river Os flux $\left({ }^{187} \mathrm{Os} /{ }^{188} \mathrm{Os}\right.$ 1.4) to the ocean (Levasseur et al., 2000; Peucker-Ehrenbrink and Ravizza, 2000), assuming no significant isotope fractionation occurs during weathering, and a primitive mantle-like ${ }^{187} \mathrm{Os} /{ }^{188} \mathrm{Os}$ for the remainder (45\%) of the continental runoff. The exact proportion, however, strongly depends on the average isotopic composition of less radiogenic sources of Os, such as young volcanic and ultramafic rocks.

The sediments in our database are likely more enriched in organic matter, and therefore also Re and radiogenic Os, than the sediments represented in the CB75 record or the sediments hosting the organic carbon in the LE13 model, and thus represent a much smaller fraction of the sedimentary record. These rarer sediments are likely deposited during punctuated global Ocean 
Anoxic Events (OAEs), or regional events that led to the formation of thick sequences of reducing sediments, such as the mid-Miocene "Monterey Event" (Vincent et al., 1985). The time-volume curves for these exceptional sediments are likely much less smooth than the two proxy models used in this study predict (Figure 4). Cannibalistic recycling that affects the CB75 but not the LE 13 record may contribute to the poor correlation between the two models.

Despite these shortcomings, we think that our approach provides reasonable estimates of the average ${ }^{187} \mathrm{Os} /{ }^{188} \mathrm{Os}$ of such sediments. Very radiogenic, old black shales (e.g. ${ }^{187} \mathrm{Os} /{ }^{188} \mathrm{Os}$ of 9.3, Horan et al., 1994) are thus very rare representatives of this already unusual sedimentary reservoir.

\subsection{Conclusions}

The calculated average ${ }^{187} \mathrm{Os} /{ }^{188} \mathrm{Os}$ value of organic-rich sediments varies between 2.22 and 2.27, with bootstrapped 95-percentile confidence intervals of 2.07 to 2.42 and 2.12 to 2.48 , respectively, depending on the proxy record used. These values indicate that organic-rich sediments and sedimentary rocks have, on average, significantly more radiogenic ${ }^{187} \mathrm{Os} /{ }^{188} \mathrm{Os}$ values compared to submarine hydrothermal $\mathrm{Os}\left({ }^{187} \mathrm{Os} /{ }^{188} \mathrm{Os}=0.12\right)$ and riverine Os (typical ${ }^{187} \mathrm{Os} /{ }^{188} \mathrm{Os}$ between 0.5 and 1.5$)$. The high concentrations of Re and Os in these sediments also indicates that they contribute a disproportionate amount to the upper continental crustal Re and Os inventories, containing as much as $\sim 70 \%$ of the UCC Re and $10 \%$ of the Os inventories even with only $0.6 \%$ of the UCC comprised of this lithology.

Based on the unusual geochemical characteristics of organic-rich marine sediments, their occurrence in the geologic record and their propensity to weather easily, it is plausible to argue that formation and subsequent recycling of such sediments, even at a constant rate, exerts a disproportionate driving force of change towards more radiogenic ${ }^{187} \mathrm{Os} /{ }^{188} \mathrm{Os}$ of seawater. Our 
calculations therefore support the notion that cycling of such sediments, even at at a constant rate, may have contributed significantly to the increasingly radiogenic ${ }^{187} \mathrm{Os} /{ }^{188}$ Os values of seawater from the early Cenozoic to the present (Ravizza, 1998; Peucker-Ehrenbrink and Ravizza, 2000). 


\begin{tabular}{|c|c|c|c|c|c|c|c|c|}
\hline Reference & Sample type & Age (Ma) & $\mathrm{C}_{\text {org }}(\mathrm{wt} . \%)$ & Os (pg/g) & $\operatorname{Re}(\mathrm{ng} / \mathrm{g})$ & ${ }^{187} \mathrm{Os} /{ }^{188} \mathrm{Os}$ & ${ }^{187} \mathrm{Re} /{ }^{188} \mathrm{Os}$ & $\begin{array}{c}{ }^{187} \mathrm{Os} /{ }^{188} \mathrm{Os} \\
\text { initial }\end{array}$ \\
\hline [1] & marine black and gray shales & 74 & 0.62 & 47 & 0.74 & 1.024 & 85 & 0.92 \\
\hline [1] & marine black and gray shales & 74 & 1 & 74 & 2.86 & 1.205 & 213 & 0.94 \\
\hline [1] & marine black and gray shales & 74 & 1.1 & 64 & 2.73 & 1.341 & 239 & 1.05 \\
\hline [1] & marine black and gray shales & 74 & 1.2 & 102 & 2.76 & 0.984 & 145 & 0.81 \\
\hline [1] & marine black and gray shales & 74 & 1.4 & 29 & 3.06 & 3.747 & 750 & 2.82 \\
\hline [1] & marine black and gray shales & 74 & 1.9 & 43 & 0.77 & 1.484 & 102 & 1.36 \\
\hline [1] & marine black and gray shales & 74 & 3.4 & 117 & 23.4 & 2.543 & 1270 & 0.98 \\
\hline [1] & marine black and gray shales & 74 & 3.7 & 170 & 33.3 & 2.564 & 1246 & 1.03 \\
\hline [1] & marine black and gray shales & 74 & 4.3 & 144 & 32.7 & 2.78 & 1476 & 0.96 \\
\hline [1] & marine black and gray shales & 74 & 10.8 & 477 & 113 & 3.149 & 1595 & 1.18 \\
\hline [1] & marine black and gray shales & 74 & 14 & 996 & 224 & 2.617 & 1439 & 0.84 \\
\hline [1] & marine black and gray shales & 74 & 14.6 & 960 & 234 & 2.497 & 1541 & 0.6 \\
\hline [1] & marine black and gray shales & 74 & 15.1 & 571 & 230 & 3.699 & 2851 & 0.18 \\
\hline [1] & marine black and gray shales & 74 & 15.9 & 548 & 147 & 3.131 & 1803 & 0.91 \\
\hline [1] & marine black and gray shales & 74 & 17.3 & 1159 & 425 & 3.665 & 2589 & 0.47 \\
\hline [1] & marine black and gray shales & 74 & 17.5 & 1097 & 306 & 3.7 & 1975 & 1.26 \\
\hline [1] & marine black and gray shales & 74 & 19.9 & 613 & 208 & 4.236 & 2517 & 1.13 \\
\hline [2] & organic rich mudstone & 209 & 0.98 & 280 & 6.13 & 0.801 & 112.5 & 0.40 \\
\hline [2] & organic rich mudstone & 205 & 1.28 & 850 & 18.4 & 1.143 & 116.2 & 0.74 \\
\hline [2] & organic rich mudstone & 208 & 1.57 & 85 & 1.07 & 0.808 & 64.3 & 0.58 \\
\hline [2] & organic rich mudstone & 208 & 1.95 & 180 & 16.7 & 1.926 & 543.5 & 0.01 \\
\hline [2] & organic rich mudstone & 206 & 2.36 & 1049 & 18.6 & 0.423 & 86.9 & 0.12 \\
\hline [2] & organic rich mudstone & 207 & 2.4 & 969 & 15.6 & 0.356 & 78.5 & 0.08 \\
\hline [2] & organic rich mudstone & 206 & 2.83 & 1769 & 18.4 & 0.339 & 50.6 & 0.16 \\
\hline [2] & organic rich mudstone & 207 & 3.24 & 210 & 5.28 & 0.755 & 128.3 & 0.30 \\
\hline [2] & organic rich mudstone & 208 & 3.66 & 228 & 1.62 & 0.561 & 35.4 & 0.44 \\
\hline [2] & organic rich mudstone & 205 & 3.95 & 742 & 72.1 & 2.121 & 579.8 & 0.10 \\
\hline [2] & organic rich mudstone & 205 & 4.5 & 830 & 87.3 & 1.785 & 605.7 & -0.33 \\
\hline [2] & organic rich mudstone & 205 & 5.08 & 1021 & 86.0 & 1.768 & 484.2 & 0.08 \\
\hline
\end{tabular}




\begin{tabular}{|c|c|c|c|c|c|c|c|c|}
\hline [2] & organic rich mudstone & 206 & 5.96 & 1110 & 18.4 & 0.491 & 82.2 & 0.20 \\
\hline [2] & organic rich mudstone & 209 & 6.3 & 136 & 0.74 & 0.842 & 28.1 & 0.74 \\
\hline [2] & organic rich mudstone & 209 & 7.66 & 147 & 3.24 & 0.882 & 114.2 & 0.48 \\
\hline [2] & organic rich mudstone & 209 & 7.9 & 144 & 1.20 & 0.852 & 43.3 & 0.70 \\
\hline [2] & organic rich mudstone & 205 & 8.1 & 1448 & 101 & 1.318 & 381.8 & -0.01 \\
\hline [2] & organic rich mudstone & 207 & 8.22 & 356 & 12.2 & 0.851 & 176.9 & 0.23 \\
\hline [2] & organic rich mudstone & 205 & 8.62 & 2004 & 87.4 & 0.848 & 225.5 & 0.06 \\
\hline [3] & organic rich mudstone & 181 & 4.63 & 246.9 & 19.36 & 2.297 & 485.1 & 0.83 \\
\hline [3] & organic rich mudstone & 201 & 5.26 & 1224 & 203.1 & 4.715 & 1278 & 0.49 \\
\hline [3] & organic rich mudstone & 200 & 5.27 & 469.9 & 62.66 & 3.397 & 917.1 & 0.38 \\
\hline [3] & organic rich mudstone & 153 & 6.4 & 400.8 & 37.85 & 2.146 & 575.2 & 0.68 \\
\hline [3] & organic rich mudstone & 158 & 6.5 & 649.4 & 15.7 & 0.721 & 125.6 & 0.39 \\
\hline [3] & organic rich mudstone & 199 & 6.75 & 579.9 & 60.05 & 2.788 & 672.5 & 0.59 \\
\hline [3] & organic rich mudstone & 153 & 7.05 & 364.5 & 28.74 & 1.935 & 469.9 & 0.73 \\
\hline [3] & organic rich mudstone & 181 & 7.1 & 256.9 & 17.54 & 2.059 & 412.1 & 0.81 \\
\hline [3] & organic rich mudstone & 203 & 7.35 & 2584 & 293.7 & 2.845 & 742.2 & 0.3 \\
\hline [3] & organic rich mudstone & 157 & 7.91 & 407.1 & 38.97 & 2.162 & 583.9 & 0.64 \\
\hline [3] & organic rich mudstone & 155 & 8.16 & 212.1 & 33.38 & 3.331 & 1076 & 0.55 \\
\hline [3] & organic rich mudstone & 203 & 8.24 & 2717 & 348 & 2.988 & 847.8 & 0.09 \\
\hline [3] & organic rich mudstone & 203 & 8.5 & 2765 & 325.6 & 2.833 & 768.1 & 0.21 \\
\hline [3] & organic rich mudstone & 181 & 8.58 & 209.4 & 6.82 & 1.68 & 271.9 & 0.86 \\
\hline [3] & organic rich mudstone & 155 & 8.6 & 281.3 & 49.75 & 3.829 & 1264 & 0.56 \\
\hline [3] & organic rich mudstone & 203 & 8.73 & 2774 & 297.5 & 2.56 & 683.7 & 0.26 \\
\hline [3] & organic rich mudstone & 181 & 8.75 & 213.1 & 11.52 & 1.631 & 311.7 & 0.69 \\
\hline [3] & organic rich mudstone & 154 & 8.97 & 471.1 & 50.28 & 2.425 & 668.7 & 0.7 \\
\hline [3] & organic rich mudstone & 203 & 8.97 & 2888 & 418.2 & 3.53 & 1007 & 0.08 \\
\hline [3] & organic rich mudstone & 199 & 9.09 & 685.7 & 133.4 & 3.807 & 1388 & -0.73 \\
\hline [3] & organic rich mudstone & 203 & 9.24 & 3172 & 455.7 & 3.746 & 1019 & 0.26 \\
\hline [3] & organic rich mudstone & 181 & 9.93 & 261.1 & 13.84 & 1.73 & 309 & 0.8 \\
\hline [3] & organic rich mudstone & 181 & 10.3 & 271.2 & 18.84 & 2.108 & 421.5 & 0.83 \\
\hline [3] & organic rich mudstone & 181 & 12.5 & 212.9 & 4.98 & 1.44 & 211.7 & 0.8 \\
\hline
\end{tabular}




\begin{tabular}{|c|c|c|c|c|c|c|c|c|}
\hline [3] & organic rich mudstone & 154 & 12.7 & 354.8 & 27.08 & 1.754 & 446 & 0.61 \\
\hline [3] & organic rich mudstone & 205 & 13.6 & 2297 & 188.9 & 2.051 & 496 & 0.35 \\
\hline [3] & organic rich mudstone & 155 & 13.8 & 615.5 & 64.98 & 2.302 & 653.4 & 0.61 \\
\hline [3] & organic rich mudstone & 155 & 13.8 & 612.1 & 65.56 & 2.346 & 665.9 & 0.62 \\
\hline [3] & organic rich mudstone & 155 & 15.9 & 711 & 96 & 2.958 & 891.3 & 0.65 \\
\hline [4] & organic rich mudstone & 181 & 6.53 & 10470 & 0.196 & 1.724 & 311.3 & 0.78 \\
\hline [4] & organic rich mudstone & 181 & 8.32 & 10800 & 0.2535 & 1.541 & 243.4 & 0.81 \\
\hline [4] & organic rich mudstone & 181 & 8.56 & 14240 & 0.2387 & 1.91 & 354.5 & 0.84 \\
\hline [5] & Bakken Shale & 354 & 11.6 & 910 & 55 & 2.95 & 398.6 & 0.59 \\
\hline [5] & Bakken Shale & 354 & 12 & 970 & 70 & 3.02 & 479.2 & 0.19 \\
\hline [5] & Bakken Shale & 354 & 12.5 & 1490 & 135 & 4.61 & 692.2 & 0.52 \\
\hline [5] & Bakken Shale & 354 & 15.1 & 3170 & 275 & 3.92 & 625.3 & 0.22 \\
\hline [5] & Bakken Shale & 354 & 15.2 & 910 & 56 & 2.92 & 404.9 & 0.53 \\
\hline [5] & Bakken Shale & 354 & 15.7 & 3450 & 285 & 3.88 & 593 & 0.37 \\
\hline [5] & Bakken Shale & 354 & 16.4 & 3690 & 259 & 3.63 & 493.2 & 0.72 \\
\hline [6] & organic-rich sediment & 0.01 & 11.7 & 166 & 31.2 & 1.053 & 1015.7 & 1.05 \\
\hline [6] & organic-rich sediment & 0.01 & 11.7 & 212 & 26.3 & 1.055 & 670.6 & 1.06 \\
\hline [6] & organic-rich sediment & 0.01 & 12 & 152 & 26.5 & 1.034 & 940.1 & 1.03 \\
\hline [6] & organic-rich sediment & 0.01 & 12.3 & 170 & 30.8 & 1.027 & 976.1 & 1.03 \\
\hline [6] & organic-rich sediment & 0.01 & 12.5 & 151 & 15.3 & 1.074 & 548.9 & 1.07 \\
\hline [7] & $\begin{array}{l}\text { dark grey and black clays and } \\
\text { shales }\end{array}$ & 165 & 2.5 & 219.4 & 13.8 & 1.477 & 355.2 & 0.5 \\
\hline [8] & dark to medium grey clay & 108.9 & 0.78 & 96.66 & 0.91 & 0.766 & 48.88 & 0.677 \\
\hline [8] & dark to medium grey clay & 108.9 & 0.97 & 93.39 & 1.52 & 0.8335 & 85.87 & 0.677 \\
\hline [8] & dark to medium grey clay & 108.9 & 1 & 101.9 & 1.49 & 0.8186 & 77.01 & 0.678 \\
\hline [8] & dark to medium grey clay & 108.9 & 1.1 & 104.47 & 2.35 & 0.8932 & 119.41 & 0.676 \\
\hline [8] & dark to medium grey clay & 108.9 & 1.12 & 116.74 & 2.16 & 0.8562 & 97.72 & 0.678 \\
\hline [8] & dark to medium grey clay & 108.9 & 1.12 & 116.74 & 2.18 & 0.8562 & 98.6 & 0.677 \\
\hline [8] & dark to medium grey clay & 93.5 & 1.49 & 488.57 & 9.82 & 0.4802 & 100.76 & 0.287 \\
\hline [8] & dark to medium grey clay & 93.5 & 1.66 & 537.81 & 8.76 & 0.4534 & 81.86 & 0.328 \\
\hline [8] & dark to medium grey clay & 93.5 & 1.89 & 555.79 & 13.04 & 0.5116 & 118.69 & 0.331 \\
\hline
\end{tabular}




\begin{tabular}{|c|c|c|c|c|c|c|c|c|}
\hline [8] & dark to medium grey clay & 93.5 & 2 & 553.11 & 18.07 & 0.5821 & 166.75 & 0.328 \\
\hline [9] & organic-rich shales & 240.1 & 2.09 & 274 & 13.61 & 1.839 & 293.2 & 0.674 \\
\hline [9] & organic-rich shales & 240.1 & 2.15 & 294 & 26.24 & 3.056 & 594.4 & 0.674 \\
\hline [9] & organic-rich shales & 240.1 & 2.19 & 292 & 14.62 & 1.839 & 295.2 & 0.674 \\
\hline [9] & organic-rich shales & 240.1 & 2.22 & 280 & 9.74 & 1.464 & 196.9 & 0.674 \\
\hline [9] & organic-rich shales & 241.2 & 2.55 & 406 & 18.1 & 1.892 & 264.4 & 0.827 \\
\hline [9] & organic-rich shales & 241.2 & 2.87 & 424 & 27.05 & 2.43 & 399.7 & 0.821 \\
\hline [9] & organic-rich shales & 240.1 & 2.89 & 370 & 29.7 & 2.768 & 520.4 & 0.674 \\
\hline [9] & organic-rich shales & 240.1 & 3.14 & 399 & 14.8 & 1.538 & 211.5 & 0.674 \\
\hline [9] & organic-rich shales & 240.1 & 3.33 & 386 & 24.94 & 2.271 & 398.1 & 0.674 \\
\hline [9] & organic-rich shales & 240.1 & 3.6 & 454 & 33.47 & 2.543 & 466.7 & 0.674 \\
\hline [9] & organic-rich shales & 241.2 & 3.95 & 647 & 65.08 & 3.682 & 709.5 & 0.825 \\
\hline [9] & organic-rich shales & 241.2 & 6 & 1118 & 161.8 & 5.67 & 1201 & 0.834 \\
\hline$[10]$ & organic carbon-rich mudstone & 358 & 5.17 & 1476 & 156.9 & 5.7972 & 891.3 & 0.47 \\
\hline$[10]$ & organic carbon-rich mudstone & 358 & 5.17 & 1538.8 & 110.5 & 3.4441 & 495.6 & 0.48 \\
\hline$[10]$ & organic carbon-rich mudstone & 358 & 5.17 & 4447 & 466.8 & 5.6777 & 872 & 0.46 \\
\hline$[10]$ & organic carbon-rich mudstone & 358 & 5.17 & 2851 & 223.8 & 3.8192 & 560.4 & 0.47 \\
\hline$[10]$ & organic carbon-rich mudstone & 358 & 5.17 & 1054.2 & 117.8 & 6.3052 & 972.3 & 0.49 \\
\hline$[10]$ & organic carbon-rich mudstone & 380 & 5.53 & 609.4 & 22.2 & 1.6172 & 209.4 & 0.25 \\
\hline$[10]$ & organic carbon-rich mudstone & 380 & 5.53 & 765.3 & 35.2 & 2.0524 & 276.9 & 0.25 \\
\hline$[10]$ & organic carbon-rich mudstone & 380 & 5.53 & 724 & 28.3 & 1.7279 & 227.7 & 0.24 \\
\hline$[10]$ & organic carbon-rich mudstone & 380 & 5.53 & 990.1 & 50.7 & 2.2974 & 316.4 & 0.24 \\
\hline$[10]$ & organic carbon-rich mudstone & 380 & 5.53 & 1768.5 & 62.3 & 1.576 & 201.8 & 0.26 \\
\hline$[10]$ & organic carbon-rich mudstone & 380 & 5.53 & 1292.7 & 69.3 & 2.4115 & 335.2 & 0.23 \\
\hline$[10]$ & organic carbon-rich mudstone & 380 & 5.53 & 966.3 & 38.6 & 1.7647 & 233.4 & 0.24 \\
\hline$[10]$ & organic carbon-rich mudstone & 364 & 5.68 & 325.2 & 37 & 7.0181 & 1041.8 & 0.68 \\
\hline$[10]$ & organic carbon-rich mudstone & 364 & 5.68 & 882.7 & 102.1 & 7.2071 & 1072.6 & 0.68 \\
\hline$[10]$ & organic carbon-rich mudstone & 364 & 5.68 & 741.6 & 91.4 & 7.9887 & 1202.7 & 0.67 \\
\hline$[10]$ & organic carbon-rich mudstone & 364 & 5.68 & 760.9 & 92.2 & 7.7937 & 1167.4 & 0.69 \\
\hline$[10]$ & organic carbon-rich mudstone & 364 & 5.68 & 272.5 & 31.9 & 7.347 & 1095.5 & 0.68 \\
\hline$[10]$ & organic carbon-rich mudstone & 364 & 5.68 & 763.3 & 90.6 & 7.5346 & 1125.2 & 0.69 \\
\hline
\end{tabular}




\begin{tabular}{|c|c|c|c|c|c|c|c|c|}
\hline [10] & organic carbon-rich mudstone & 370 & 6.26 & 1009.1 & 89.5 & 4.611 & 677.2 & 0.42 \\
\hline [10] & organic carbon-rich mudstone & 370 & 6.26 & 357.1 & 26.1 & 3.585 & 510.9 & 0.43 \\
\hline [10] & organic carbon-rich mudstone & 370 & 6.26 & 372.2 & 26.7 & 3.4934 & 498.4 & 0.41 \\
\hline [10] & organic carbon-rich mudstone & 370 & 6.26 & 661.8 & 59.8 & 4.7334 & 697.5 & 0.42 \\
\hline [10] & organic carbon-rich mudstone & 370 & 6.26 & 741.7 & 59.9 & 4.0464 & 587.7 & 0.41 \\
\hline [11] & marine shale & 252 & 1.79 & 73.07 & 3.74 & 1.8304 & 301.2 & 0.56 \\
\hline [11] & marine shale & 252 & 2.16 & 86.2 & 5.48 & 2.224 & 390.3 & 0.58 \\
\hline [11] & marine shale & 252 & 1.82 & 87.18 & 3.1 & 1.2067 & 195.7 & 0.48 \\
\hline [11] & marine shale & 252 & 0.92 & 75.54 & 2.34 & 1.2321 & 170.7 & 0.51 \\
\hline [11] & marine shale & 252 & 1.06 & 107.72 & 3.33 & 1.1582 & 168.9 & 0.45 \\
\hline [11] & marine shale & 252 & 0.75 & 163.7 & 10.86 & 2.181 & 405.4 & 0.48 \\
\hline [11] & marine shale & 252 & 0.65 & 242.8 & 7.8 & 0.9141 & 170.6 & 0.2 \\
\hline [11] & marine shale & 252 & 0.92 & 378.7 & 68.3 & 7.913 & 1753 & 0.54 \\
\hline [12] & organic-rich black mudstone & 1105 & 7.75 & 3147.9 & 152.6 & 10.398 & 546.44 & 0.2 \\
\hline [12] & organic-rich black mudstone & 1105 & 9.06 & 3733.4 & 198.1 & 13.332 & 696.24 & 0.34 \\
\hline [12] & organic-rich black mudstone & 1105 & 8.84 & 3654.6 & 182.3 & 11.098 & 584.27 & 0.19 \\
\hline [12] & organic-rich black mudstone & 1105 & 1.69 & 788.5 & 36.9 & 9.785 & 509.37 & 0.28 \\
\hline [12] & organic-rich black mudstone & 1105 & 2.81 & 1708.3 & 77.1 & 9.05 & 470.81 & 0.34 \\
\hline [12] & organic-rich black mudstone & 1105 & 2.88 & 1510 & 65.2 & 8.369 & 431.81 & 0.31 \\
\hline [12] & organic-rich black mudstone & 1105 & 3.69 & 2063 & 101.5 & 10.781 & 566.71 & 0.2 \\
\hline [12] & organic-rich black mudstone & 1105 & 4.13 & 1679.6 & 79.9 & 10.099 & 527.55 & 0.25 \\
\hline [12] & organic-rich black mudstone & 1105 & 0.84 & 959.5 & 42.8 & 8.973 & 462.95 & 0.33 \\
\hline [12] & organic-rich black mudstone & 1107 & 16.48 & 1569 & 86.9 & 14.821 & 778.26 & 0.3 \\
\hline [12] & organic-rich black mudstone & 1107 & 4.88 & 285.1 & 14.4 & 11.536 & 606.46 & 0.22 \\
\hline [12] & organic-rich black mudstone & 1107 & 8.34 & 674 & 33.8 & 11.349 & 594.88 & 0.25 \\
\hline [12] & organic-rich black mudstone & 1107 & 8.69 & 671.5 & 36.2 & 13.66 & 718.15 & 0.26 \\
\hline [12] & organic-rich black mudstone & 1107 & 9.37 & 874.4 & 46.9 & 13.375 & 704.63 & 0.22 \\
\hline [12] & organic-rich black mudstone & 1107 & 7.41 & 920.1 & 46.3 & 11.455 & 600.63 & 0.24 \\
\hline [12] & organic-rich black mudstone & 1107 & 10.38 & 1000.7 & 57.7 & 16.369 & 865.87 & 0.21 \\
\hline [12] & organic-rich black mudstone & 1109 & 13.6 & 2139.9 & 113.6 & 13.156 & 690.49 & 0.27 \\
\hline [12] & organic-rich black mudstone & 1109 & 6.49 & 812.7 & 44.4 & 14.282 & 749.24 & 0.3 \\
\hline
\end{tabular}




$\begin{array}{llllccccc}{[12]} & \text { organic-rich black mudstone } & 1109 & 2.06 & 303.2 & 17.4 & 16.641 & 874.08 & 0.33 \\ {[12]} & \text { organic-rich black mudstone } & 1109 & 7.25 & 1090.4 & 57.6 & 13.049 & 683.17 & 0.3 \\ {[12]} & \text { organic-rich black mudstone } & 1109 & 2.46 & 410.9 & 25 & 19.662 & 1041.5 & 0.22 \\ {[12]} & \text { organic-rich black mudstone } & 1109 & 6.19 & 914.2 & 50.2 & 14.539 & 761.44 & 0.33\end{array}$

References:

[1] Baioumy et al., 2011

[2] Cohen and Coe, 2002

[3] Cohen et al., 1999

[4] Cohen et al., 2004

[5] Ravizza and Turekian, 1989

[6] Ravizza and Turekian, 1992

[7] Rooney et al., 2012

[8] Selby et al., 2009

[9] Xu et al., 2009

[10] Harris et al., 2013

[11] Georgiev et al., 2015

[12] Rooney et al., 2010

Table 2.1 Geochemical Database of Re and Os concentrations and Isotopes, as well as Age and TOC. Calculated values are italicized 


\begin{tabular}{|l|l|l|}
\hline Parameter & Median value & Bootstrapped 95-percentile confidence interval \\
\hline${ }^{187} \mathrm{Re} /{ }^{188} \mathrm{Os}$ & 517 & $(468,582)$ \\
\hline TOC & $5.8 \mathrm{wt} . \%$ & $(5.4,6.3)$ \\
\hline $\begin{array}{l}{ }^{187} \mathrm{Os} /{ }^{188} \text { Os (using } \\
\mathrm{CB} 75 \text { model) }\end{array}$ & 2.27 & $(2.12,2.48)$ \\
\hline $\begin{array}{l}187 \mathrm{Os} /{ }^{188} \text { Os (using } \\
\mathrm{LE} 13 \text { model) }\end{array}$ & 2.22 & $(2.07,2.42)$ \\
\hline $\begin{array}{l}{ }^{187} \mathrm{Os} /{ }^{188} \text { Os (from } \\
\text { filtered database) }\end{array}$ & 2.42 & $(2.13,2.79)$ \\
\hline
\end{tabular}

Table 2.2 Summary of the median values as well as 95-percentile confidence intervals of various parameters calculated from the filtered database. 


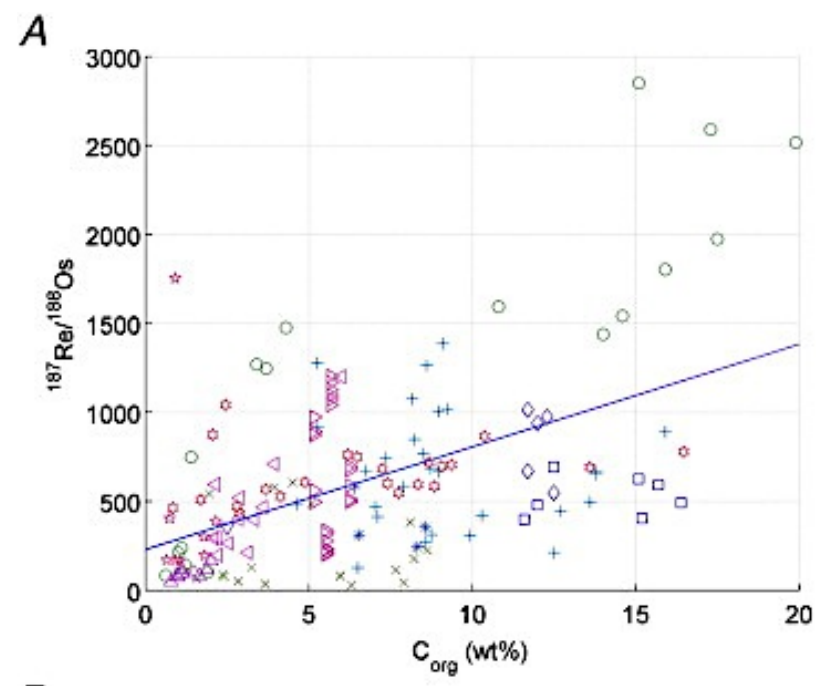

- Baioumy et al., 2011 - marine black and gray shales

$\times$ Cohen and Coe, 2002 - organic-rich mudstone

+ Cohen et al., 1999 - organic-rich mudstone

* Cohen et al., 2004 - organic-rich mudstone

- Ravizza and Turekian, 1989 - Bakken shale

Ravizza and Turekian, 1992 - organic-rich sediment

$\nabla$ Rooney et al., 2012 - dark grey and black clays and shales

$\triangle$ Selby et al., 2009 - dark to medium grey clay

$\triangleleft \mathrm{Xu}$ et al., 2009 - organic-rich shales

D Harris et al., 2013 - organic carbon-rich mudstone

t Georgiev et al., 2015 - marine shale

t Rooney et al., 2010 - organic-rich black mudstone

$B$

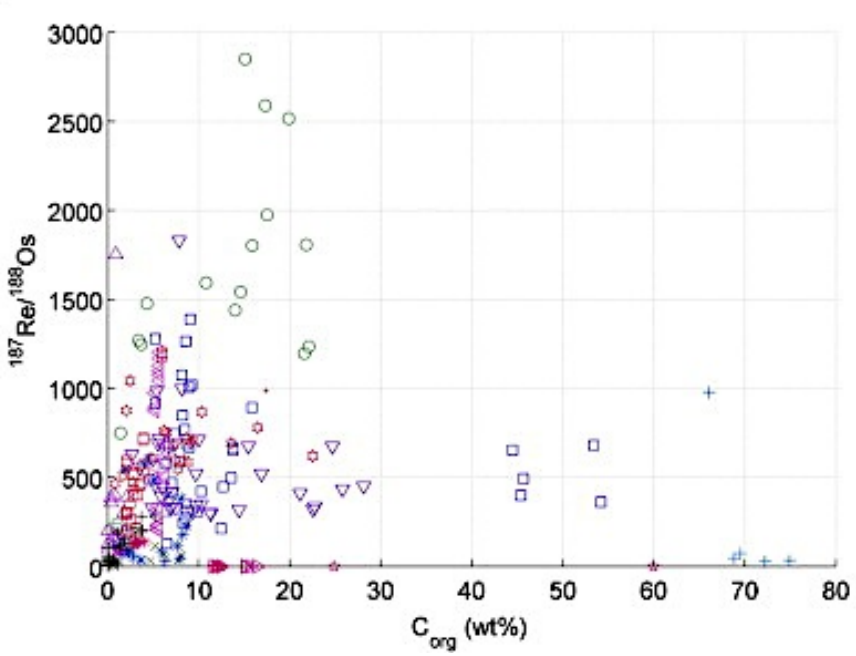

Baicumy et al., 2011 - marine black and gray shales

x Baicumy et al., 2011 - non-marine black shale

+ Baicumy et al., $2011 \cdot$ non-marine coal

* Cohen and Coe, 2002 - organic rich mudstone

- Cohen et al., 1999 - organic rich mudstone

$\checkmark$ Cohen et al., 1999 - pyrite nodule

$\nabla$ Cumming et al., 2012 - grey-black carbonaceous mudstones

$\triangle$ Georgiev et al., 2015 - marine shales

4 Harris et al., 2013 - organic carbon-rich mudstone

D Ravizza and Turekian, 1989 - Bakken Shale

* Ravizza and Turekian, 1992 - organic-rich sediment

- Rooney et al., 2010 - organic-rich black mudstone

- Rooney et al., 2012 - argillaceous phosphatic claystone

- Rooney et al., 2012 - dark grey and black clays and shales

x Selby et al., 2009 - dark to medium grey clay

+ Tejada et al., 2009 - unknown

* Turgeon et al., 2007 - unknown

- Xu et al., 2009 - organic-rich shales

Figure $2.1{ }^{187} \mathrm{Re}^{188} \mathrm{Os}$ values plotted against TOC concentrations for the filtered (A) and unfiltered (B) database. The blue line indicates the best fit for the least-squares linear regression. For the unfiltered database, only samples for which both ${ }^{187} \mathrm{Re} /{ }^{188}$ Os and TOC concentrations are reported are included (277 data points). The various symbols represent different types of samples referenced in the reference list. The figure illustrates the presence of samples with very high TOC concentrations but low ${ }^{187} \mathrm{Re} /{ }^{188} \mathrm{Os}$, which cause a large bias in the distribution if not filtered out. 




Figure 2.2 Histogram showing the distribution of ${ }^{187} \mathrm{Re} /{ }^{188} \mathrm{Os}$. 


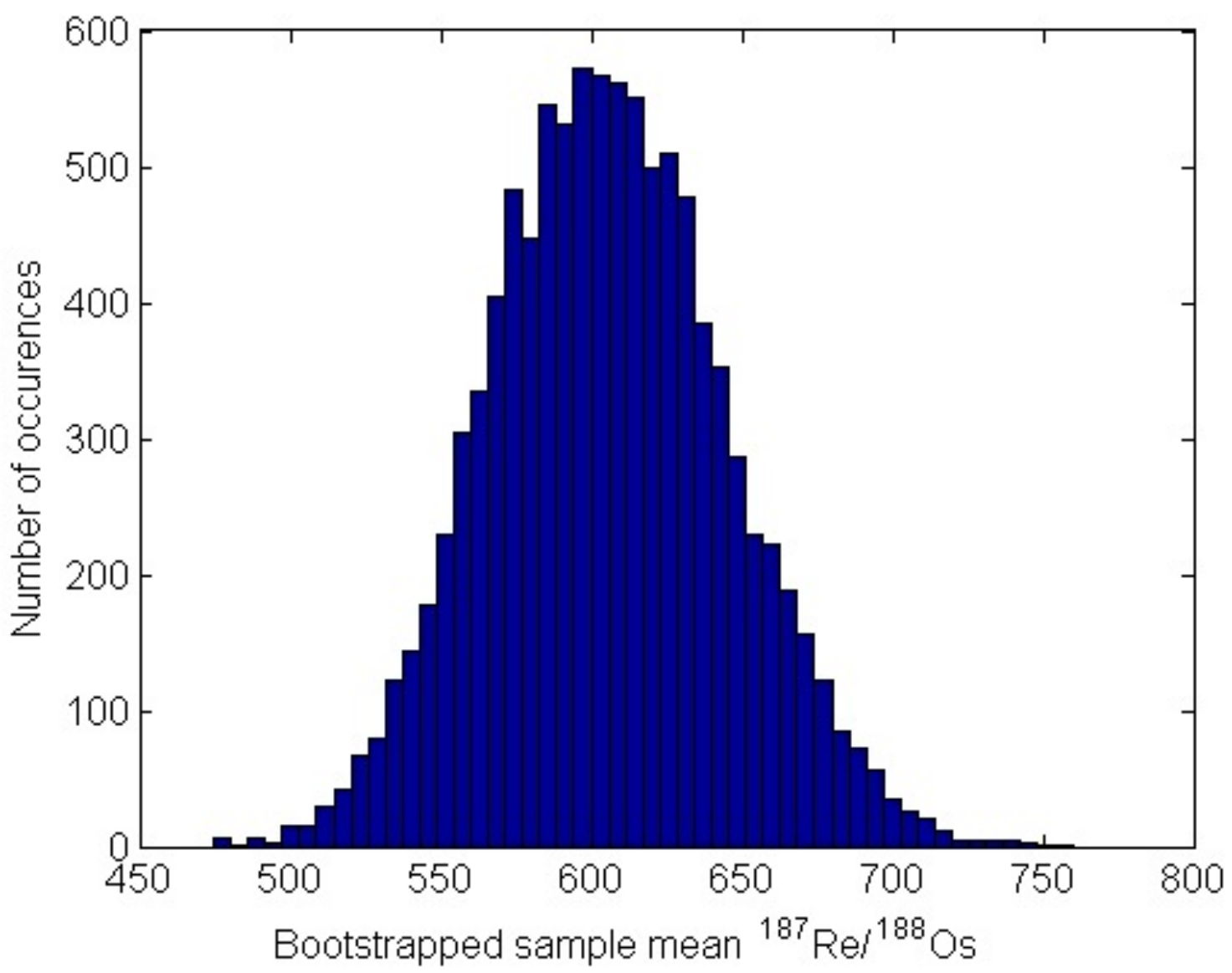

Figure 2.3 Histogram showing the means of each bootstrapped sample of the filtered database. The mean remains 605 , but this approach allows us to understand variations on the mean. 




1. Monterey Event; Vincent et al., 1985

2. PETM; Sluijs et al., 2014

3. OAE 3; Wagreich, 2012

4. OAE 2; Leckie et al., 2002

5. OAE 1d; Leckie et al., 2002

(a)

6. OAE 1b; Leckie et al., 2002

7. OAE 1a; Leckie et al., 2002

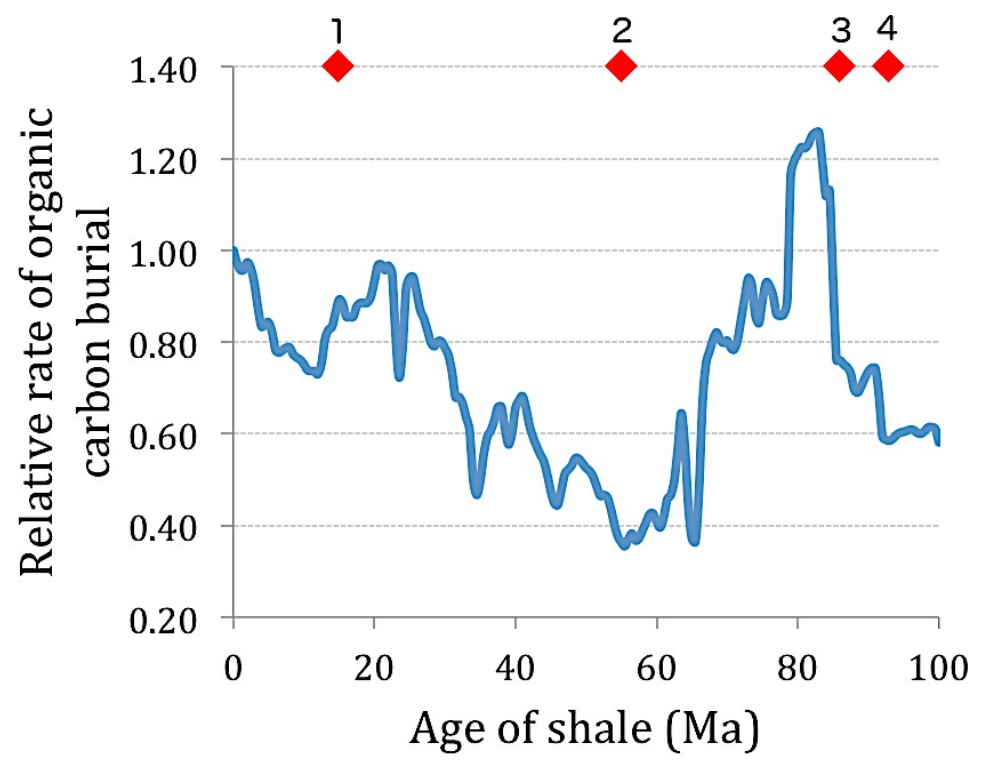

8. Toarcian OAE; Schouten et al., 2000

9. Permian-Triassic boundary; Isozaki, 1997

10. Mississippian; Rimmer, 2004

11. Late Devonian; Goodfellow and Jonasson, 1984

12. Early Silurian; Goodfellow and Jonasson, 1984

(b)

Figure 2.4 Comparison of the two proxy models - (a) Cook and Balley (1975) and (b) Li and Elderfield (2013). The grey box in Figure 4a indicates the time period represented in Figure $4 \mathrm{~b}$. Note that the temporal resolution on the LE13 model (0.5 Myr) is much higher than the CB75 record (on average 14.4 Myr). Red diamonds indicate periods of significant ocean anoxic events. 


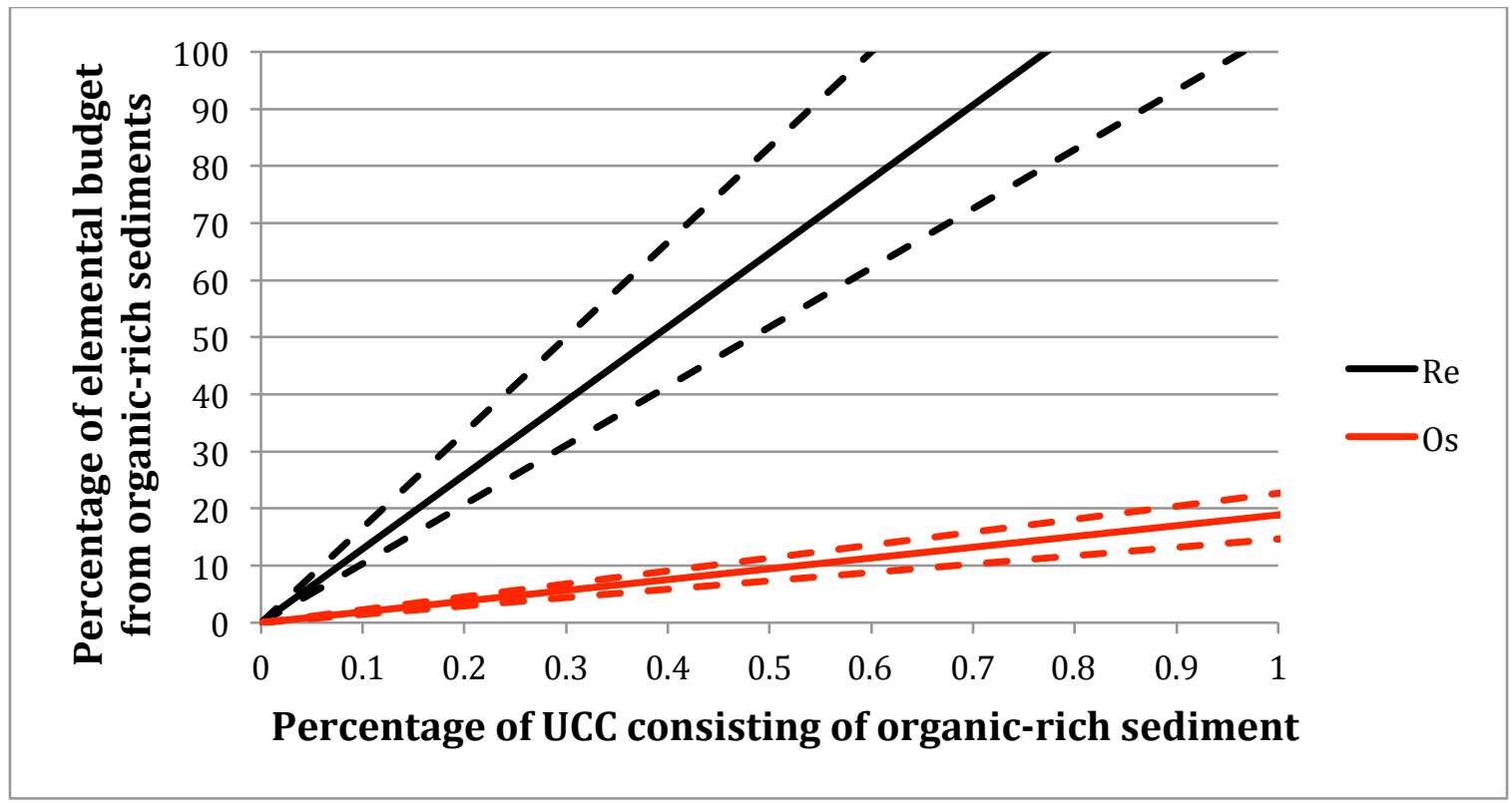

Figure 2.5 Relative contributions of Re and Os to the upper continental inventories stemming from organic-rich sediment. The dashed lines represent the 95 percentile confidence interval based on the uncertainties of the Re and Os concentrations in the sediment. 


\section{Acknowledgements}

This research was funded by a grant from the Ocean and Climate Change Institute at the Woods Hole Oceanographic Institution to BPE. The work was also partially funded by the United States Environmental Protection Agency through an EPA STAR fellowship to AD, and by the WHOI Academic Programs Office. We thank David Glover for his advise on statistical treatment of non-normally distributed data. We also thank three reviewers - Laurie Reisberg, AC Pierson-Wickmann, and another anonymous reviewer - for their thoughtful comments on this manuscript. 


\subsection{References}

Ahrens, T.J. (ed), 1995. AGU Reference Shelf 1, Global Earth Physics, A Handbook of Physical Constants, page 8.

Allègre, C., Manhès, G., Lewin, É, 2001. Chemical composition of the Earth and the volatility control on planetary genetics. Earth and Planetary Science Letters 185, 49-69.

Anbar, A.D., Creaser, R.A., Papanastassiou, D.A., Wasserburg, G.J. 1992. Rhenium in seawater: confirmation of generally conservative behavior. Geochimica et Cosmochimica Acta 56, 40994103.

Baioumy, H.M., Eglinton, L.B., Peucker-Ehrenbrink, B., 2011. Rhenium-osmium isotope and platinum group element systematics of marine vs. non-marine organic-rich sediments and coals from Egypt. Chemical Geology 285, 70-93.

Berry, J.P., Wilkinson, B.H., 1994. Paleoclimatic and tectonic control on the accumulation of North American cratonic sediments. Geological Society of America Bulletin 106, 855-865.

Brody, J.P., Williams, B.A., Wold, B.J., Quake, S.R. 2002. Significance and statistical errors in the analysis of DNA microarray data. Proceedings of the National Academy of Sciences of the United States of America 99, 12975-12978.

Cohen, A.S., Coe, A.L., Bartlett, J.M., Hawkesworth, C.J. 1999. Precise Re-Os ages of organicrich mudrocks and Os isotope composition of Jurassic seawater. Earth and Planetary Science Letters 167, 159-173.

Cohen, A.S., Coe, A.L., 2002. New geochemical evidence for the onset of volcanism in the Central Atlantic magmatic province and environmental change at the Triassic-Jurassic boundary. Geology 30, 267-270.

Cohen, A.S., Coe, A.L., Harding, S.M., Schwark, L., 2004. Osmium isotope evidence for the regulation of atmospheric CO2 by continental weathering. Geology 32, 157-160.

Colodner, D., Sachs, J., Ravizza, G., Turekian, K.K., Edmond, J., Boyle, E., 1993. The geochemical cycle of rhenium: a reconnaissance. Earth and Planetary Science Letters 117, 205221.

Cook, T.D., Bally, A.W., 1975. Stratigraphic Atlas North and Central America. Shell Oil Co., Exploration Dept., Houston.

Crusius, J., Calvert, S., Pedersen, T., Sage, D. 1996. Rhenium and molybdenum enrichments in sediments as indicators of oxic, suboxic and sulfidic conditions of deposition. Earth and Planetary Science Letters 145, 65-78. 
Crusius, J., Thomson, J., 2000. Comparative behavior of authigenic Re, U, and Mo during reoxidation and subsequent long-term burial in marine sediments. Geochimica et Cosmochimica Acta 64, 2233-2242.

Cumming, V.M., Selby, D., Lillis, P.G., 2012. Re-Os geochronology of the lacustrine Green River Formation: Insights into direct depositional dating of lacustrine successions, Re-Os systematics and paleocontinental weathering. Earth and Planetary Science Letters 359, 194-205.

Dalai, T.K., Suzuki, K., Minagawa, M., Nozaki, Y., 2005. Variations in seawater osmium isotope composition since the last glacial maximum: A case study from Japan Sea. Chemical Geology 220, 303-314.

Dalai, T.K., Ravizza, G.E., Peucker-Ehrenbrink, B., 2006. The Late Eocene ${ }^{187} \mathrm{Os} /{ }^{188} \mathrm{Os}$ excursion: Chemostratigraphy, cosmic dust flux and the Early Oligocene glaciation. Earth and Planetary Science Letters 241, 477-492.

Efron, B., 1979. Bootstrap methods: Another look at the jackknife. Annals of Statistics 7, 1-26.

Esser, B.K., Turekian, K.K., 1993. The osmium isotopic composition of the continental crust. Geochimica et Cosmochimica Acta 57, 3093-3104.

Garrels, R.M., Mackenzie, F.T., 1969. Sedimentary rock types: relative proportions as a function of geologic time. Science 168, 570-571.

Georgiev, S., Stein, H.J., Hannah, J.L., Bingen, B., Weiss, H.M., Piasecki, S., 2011. Hot acidic Late Permian seas stifle life in record time. Earth and Planetary Science Letters 310, 389-400.

Georgiev, S., Stein, H.J., Hannah, J.L., Henderson, C.M., Alego, T.J., 2015. Enhanced recycling of organic matter and Os-isotopic evidence for multiple magmatic or meteoritic inputs to the Late Permian Panthalassic Ocean, Opal Creek, Canada. Geochimica et Cosmochimica Acta 150, 192-210.

Goldschmidt, V.M., 1922. Der Stoffwechsel der Erde. Skrifter utgit av Videnskapsselskapets I Kristiana. I, Matematisk-Naturvidenskabelig Klasse 11, 3-25.

Goldstein, S.L., 1988. Decoupled evolution of $\mathrm{Nd}$ and $\mathrm{Sr}$ isotopes in the continental crust and the mantle. Nature 336, 733-738.

Goodfellow, W.D., Jonasson, I.R., 1984. Ocean stagnation and ventilation defined by $\delta^{34} \mathrm{~S}$ secular trends in pyrite and barite, Selwyn Basin, Yukon. Geology 12, 583-586.

Harris, N.B., Mnich, C.A., Selby, D., Korn, D., 2013. Minor and trace element and Re-Os chemistry of the Upper Devonian Woodford Shale, Permian Basin, west Texas: Insights into metal abundance and basin processes. Chemical Geology 356, 76-93. 
Hilton, R.G., Gaillardet, J., Calmels, D., Birck, J.-L., 2014. Geological respiration of a mountain belt revealed by the trace element rhenium. Earth and Planetary Science Letters 403, 27-36.

Horan, M.F., Morgan, J.W., Grauch, R.I., Coveney, R.M. Jr., Murowchick, J.B., Hulbert, L.J., 1994. Rhenium and osmium isotopes in black shales and Ni-Mo-PGE-rich sulfide layers, Yukon Territory, Canada, and Hunan and Guishou provinces, China. Geochimica et Cosmochimica Acta 58, 257-265.

Isozaki, Y., 1997. Permo-Triassic boundary superanoxia and stratified superocean: records from lost deep sea. Science 276, 235-238.

Jacobson, S.B., Wasserburg, G.J., 1979. The mean age of mantle and crustal reservoirs. Journal of Geophysical Research 84, 7411-7427.

Jaffe, L.A., Peucker-Ehrenbrink, B., Petsch, S.T., 2002. Mobility of rhenium, platinum group elements and organic carbon during black shale weathering. Earth and Planetary Science Letters 198, 339-353.

Kendall, B., Creaser, R.A., Selby, D., 2009. ${ }^{187}$ Re- ${ }^{187}$ Os geochronology of Precambrian organicrich sedimentary rocks. Special Publication - Geological Society of London 326, 85-107.

Koide, M., Goldberg, E.D., Niemeyer, S., Gerlach, D., Hodge, V., Bertine, K.K., Padova, A., 1991. Osmium in marine sediments. Geochimica et Cosmochimica Acta 55, 1641-1648.

Koide, M., Hodge, V.F., Yang, J.S., Stallard, M., Goldberg, E.G., Calhoun, J., Bertine, K.K., 1986. Some comparative marine chemistries of rhenium, gold, silver and molybdenum. Applied Geochemistry 1, 705-714.

Leckie, R.M., Bralower, T.J., Cashman, R., 2002. Oceanic anoxic events and plankton evolution: biotic response to tectonic forcing during the mid-Cretaceous. Paleoceanography 17, doi: 10.1029/2001PA000623.

Levasseur, S., Rachold, V., Brick, J.L., Allegre, C.J., 2000. Osmium behaviour in estuaries: the Lena River example. Earth and Planetary Science Letters 177, 227-235.

Lewan, M.D., Maynard, J.B., 1982. Factors controlling enrichment of vanadium and nickel in the bitumen of organic sedimentary rocks. Geochimica et Cosmochimica Acta 46, 2547-2560.

Li, Y.H., 1972. Geochemical mass balance among lithosphere, hydrosphere, and atmosphere. American Journal of Science 272, 119-137.

Li, G.J., Elderfield, H., 2013. Evolution of carbon cycle over the past 100 million years. Geochimica et Cosmochimica Acta 103, 11-25.

Lilliefors, H.W., 1967. On the Kolmogorov-Smirnov test for normality with mean and variance unknown. Journal of the American Statistical Association 62, 399-402. 
Lilliefors, H.W., 1969. On the Kolmogorov-Smirnov test for the exponential distribution with mean unknown. Journal of the American Statistical Association 64, 387-389.

Martin, C.E., Peucker-Ehrenbrink, B., Brunskill, G., Szymczak, R., 2001. Osmium isotope geochemistry of a tropical estuary. Geochimica et Cosmochimica Acta 65, 3193-3200.

Meisel, T., Walker, R.J., Morgan, J.W., 1996. The osmium isotopic composition of the Earth's primitive upper mantle. Nature 383, 517-520.

Miller, C.A., Peucker-Ehrenbrink, B., Walker, B.D., Marcantonio, F., 2011. Re-assessing the surface cycling of molybdenum and rhenium. Geochimica et Cosmochimica Acta 75, 7146-7179.

Morford, J.L., Emerson, S., 1999. The geochemistry of redox sensitive trace metals in sediments. Geochimica et Cosmochimica Acta 63, 1735-1750.

Noddack, I., Noddack, W., 1931. Die Geochemie des Rheniums. Zeitschrift für Physikalische Chemie 154A, 207-244.

Paquay, F.S., Ravizza, G.E., Dalai, T.K., Peucker-Ehrenbrink, B., 2008. Determining chondritic impactor size from the marine osmium isotope record. Science 320, 214-218.

Pegram, W.J., Krishnaswami, S., Ravizza, G.E., Turekian, K.K., 1992. The record of sea water ${ }^{187} \mathrm{Os} /{ }^{186}$ Os variations through the Cenozoic. Earth and Planetary Science Letters 113, 569-576.

Peucker-Ehrenbrink, B., Blum, J.D., 1998. Re-Os isotope systematics and weathering of Precambrian crustal rocks: implications for the marine osmium isotope record. Geochimica et Cosmochimica Acta 62, 3193-3203.

Peucker-Ehrenbrink, B., Hannigan, R.E., 2000. Effects of black shale weathering on the mobility of rhenium and platinum group elements. Geology 28, 475-478.

Peucker-Ehrenbrink, B., Jahn, B.M., 2001. Rhenium-osmium isotope systematics and platinum group element systematics: Loess and the upper continental crust. Geochemisty, Geophysics, Geosystems 2, $2001 \mathrm{GC} 000172$.

Peucker-Ehrenbrink, B., Miller, M.W., 2007. Quantitative bedrock geology of the continents and large-scale drainage regions. Geochemisty, Geophysics, Geosystems 8, DOI:

10.1029/2006GC001544.

Peucker-Ehrenbrink, B., Ravizza, G., 2000. The marine osmium isotope record. Terra Nova 5, 12, 205-219.

Peucker-Ehrenbrink, B., Ravizza, G., 2012. Osmium Isotope Stratigraphy. In: The Geologic Time Scale 2012. (F.M. Gradstein, J.G. Ogg, M.D. Schmitz, G.M. Ogg, Eds.), Elsevier, Oxford, $\mathrm{UK}, 23 \mathrm{pp}$. 
Pierson-Wickmann, A.C., Reisberg, L., France-Lanord, C., 2000. The Os-isotope composition of Himalayan bedloads and bedrocks: Importance of black shales. Earth and Planetary Science Letters 176, 203-218.

Pierson-Wickmann, A.C., Reisberg, L., France-Lanord, C., 2002. Behavior of Re and Os during low-temperature alteration: Results from Himalayan soils and altered black shales. Geochimica et Cosmochimica Acta 66, 1539-1548.

Ravizza, G., 1998. Osmium-isotope geochemistry of Site 959: implications for Re-Os sedimentary geochronology and reconstruction of past variations in the Os-isotopic composition of seawater. Proceedings of the Ocean Drilling Program, Scientific Results 159, 181-186.

Ravizza, G., Esser, B.K., 1993. A possible link between the sea water osmium isotope record and weathering of ancient sedimentary organic matter. Chemical Geology 107, 255-258.

Ravizza, G., Martin, C.E., German, C.R., Thompson, G., 1996. Os isotopes as tracers in seafloor hydrothermal systems; metalliferous deposits from the TAG hydrothermal area, 26 degrees N Mid-Atlantic Ridge. Earth and Planetary Science Letters 138, 105-119.

Ravizza, G., Turekian, K.K., 1989. Application of the ${ }^{187}$ Re- $^{187}$ Os system to black shale geochronometry. Geochimica et Cosmochimica Acta 53, 3257-3262.

Ravizza, G., Turekian, K.K., 1992. The osmium isotopic composition of organic-rich marine sediments. Earth and Planetary Science Letters 110, 1-6.

Ravizza, G., Turekian, K.K., Hay, B.J., 1991. The geochemistry of rhenium and osmium in recent sediments from Black Sea. Geochimica et Cosmochimica Acta 55, 3741-3752.

Reusch, D.N., 2011. New Caledonian carbon sinks at the onset of Antarctic glaciation. Geology $39,807-810$.

Rimmer, S.M., 2004. Geochemical paleoredox indicators in Devonian-Mississippian black shales, central Appalachian basin (USA). Chemical Geology 206, 373-391.

Robinson, N., Ravizza, G., Coccioni, R., Peucker-Ehrenbrink, B., Norris, R., 2009. A highresolution marine $187 \mathrm{Os} / 188 \mathrm{Os}$ record for the late Maastrichtian: Distinguishing the chemical fingerprints of Deccan volcanism and the KP impact event. Earth and Planetary Science Letters $281,159-168$

Ronov, A.B., 1980. The Earth's sedimentary shell: Quantitative patterns of its stuctures, compositions and evolution. The $20^{\text {th }}$ Vernadskiy lecture, Vol.1. In: The Earth's sedimentary shell (A.A. Yaroshevskiy, Ed.), Nauka, Moscow, 1-80.

Rooney, A.D., Selby, D., Houzay, J.-P., Renne, P.R., 2010. Re-Os geochronology of a Mesoproterozoic sedimentary succession, Taoudeni basin, Mauritania: Implications for basin- 
wide correlations and Re-Os organic-rich sediments systematics. Earth and Planetary Science Letters 289, 486-496.

Rooney, A.D., Selby, D., Lewan, M.D., Lillis, P.G., Jouzay, J.P., 2012. Evaluating Re-Os systematics in organic-rich sedimentary rocks in response to petroleum generation using hydrous pyrolysis experiments. Geochimica et Cosmochimica Acta 77, 275-291.

Schmidt, G., Palme, H., Kratz, K.L., 1997. Fractionation of highly siderophile elements in the Earth's upper continental crust, Yearbook Institute for Nuclear Chemistry, Mainz, Germany, p.15.

Schmidt, G., Palme, H., 1997. Adundances of Os, Ir, Ru, Rh, Pt and Pd in the Earth's crust. In: EAG Workshop 1997, The origin and fractionation of highly siderophile elements in the Earth's mantle. Max-Planck-Institute für Chemie, Mainz, 14-16 May 1997, p. 71-72.

Schouten, S., van Kaam-Peters, H.M.E., Rijpstra, W.I.C., Schoell, M., Damste, J.S.S., 2000. Effects of an oceanic anoxic event on the stable carbon isotopic composition of Early Toracian carbon. American Journal of Science 300, 1-22.

Selby, D., Creaser, R.A., 2003. Re-Os geochronology of organic-rich sediments: an evaluation of organic matter analysis. Chemical Geology 200, 225-240.

Selby, D., Mutterlose, J., Condon, D.J., 2009. U-Pb and Re-Os geochronology of the Aptian/Albian and Cenomanian/Turonian stage boundaries: Implications for timescale calibration, osmium isotope seawater composition and Re-Os systematics in organic-rich sediments. Chemical Geology 265, 394-409.

Sharma, M., Papanastassiou, D.A., Wasserburg, G.J., 1997. The concentration and isotopic composition of osmium in the oceans. Geochimica et Cosmochimica Acta 61, 3287-3299.

Singh, S.K., Trivedi, J.R., Krishnaswami, S., 1999. Re-Os isotope systematics in black shales from the Lesser Himalaya: Their chronology and role in the ${ }^{187} \mathrm{Os} /{ }^{188} \mathrm{Os}$ evolution of seawater, Geochimica et Cosmochimica Acta 63, 2381-2392.

Sluijs, A., van Roij, L., Harrington, G.J., Schouten, S., Sessa, J.A., Levay, L.J., Reichart, G.J., Slomp, C.P., 2014. Warming, euxinia and sea level rise during the Paleocene-Eocene Thermal Maximum on the Gulf Coastal Plain: implications for ocean oxygenation and nutrient cycling. Climate of the Past 10, 1421-1439.

Smoliar, M.I., Walker, R.J., Morgan, J.W., 1996. Re-Os ages of group IIA, IIIA IVA, and IVB iron meteorites. Science 271, 1099-1102.

Sun, W.D., Bennett, V.C., Eggins, S.M., Kamenetsky, V.S., Arculus, R.J., 2003. Enhanced mantle-to-crust rhenium transfer in undegassed arc magmas. Nature 422, 294-297. 
Suzuki, K., Qi-Lu, Shimizu, H., Masuda A., 1993. Reliable Re-Os age for molybdenite. Geochimica et Cosmochimica Acta 57, 1625-1628.

Taylor, S.R., McLennan, S.M., 1985. The Continental Crust: Its Composition and Evolution. Blackwell Science, Malden, Mass. 312 pp.

Tejada, M.L.G., Suzuki, K., Kuroda, J., Coccioni, R., Mahoney, J.J., Ohkouchi, N., Sakamoto, T., Tatsumi, Y., 2009. Ontong Java Plateau eruption as a trigger for the early Aptian oceanic anoxic event. Geology 37, 855-858.

Turgeon, S.C., Creaser, R.A., Algeo, T.J., 2007. Re-Os depositional dates and seawater Os for the Frasnian-Famennian boundary: Implications for weathering rates, land plant evolution, and extinction mechanisms. Earth and Planetary Science Letters 261, 649-661.

Vincent, E., Killingley, J.S., Berger, W.H., 1985. Miocene oxygen and carbon isotope stratigraphy in the tropical Indian-Ocean. Geological Society of America Memoirs 163, 103-130.

Wagreich, M., 2012. "OAE 3" - regional Atlantic organic carbon burial during the ConiacianSantonian. Climate of the Past 8, 1447-1455.

Wilkinson, B.H., McElroy, B.J., Kesler, S.E., Peters, S.E., Rothman, E.D., 2009. Global geologic maps are tectonic speedometers - rates of rock cycling from area-age frequencies. Geological Society of America Bulletin 121, 760-779.

Xu, G.P., Hannah, J.L., Stein, H.J., Bingen, B., Yang, G., Zimmerman, A., Weitschat, W., Mork, A., Weiss, H.M., 2009. Re-Os geochronology of Arctic black shales to evaluate the AnisianLadinian boundary and global faunal correlations. Earth and Planetary Science letters 288, 581587.

Yamashita, Y., Takahashi, Y., Haba, H., Enomoto, S., Shimizu, H., 2007. Comparison of reductive accumulation of Re and Os in seawater-sediment systems. Geochimica et Cosmochimica Acta 71, 3458-3475. 


\subsection{Supplementary data}

The unfiltered database is included as supplementary data for this chapter, and can be found at http://mit.edu/ adubin/www/Supplemental_Data1.xlsx 


\section{CHAPTER 3.}

\section{Lead isotope records across the PETM as recorded in DSDP Site 549 and ODP Site 690}

\subsection{Abstract}

The Paleocene-Eocene Thermal Maximum (PETM) is characterized by a rapid excursion to lower $\delta^{13} \mathrm{C}$ (a measure of the ratio of ${ }^{13} \mathrm{C} /{ }^{12} \mathrm{C}$ compared to the standard $\mathrm{PDB}$ ) values in marine and terrestrial carbonates in the sediment records, known as the carbon isotope excursion (CIE). The cause of the rapid release of isotopically light carbon to the ocean-atmosphere system that is needed to generate the CIE is unknown. In this chapter, I examine whether inorganic isotope systematics might be useful for identifying the source of carbon, and specifically whether sediment records from DSDP Site 549 and ODP Site 690 display evidence of a source of carbon from organic-rich sediments at the PETM. The lead isotope system is chosen as uranium, which decays to lead, is enriched over continental crust in organic-rich sediments, causing these sediments to develop a unique $\mathrm{Pb}$ isotope signature. The isotope data from the two cores do not support a source of lead from organic-rich sediments during the PETM.

\subsection{Introduction}

The Paleocene-Eocene boundary $(56 \mathrm{Ma})$ is marked by a pronounced decrease in ${ }^{13} \mathrm{C} /{ }^{12} \mathrm{C}$ (known as the Carbon Isotope Excursion; CIE) of marine and terrestrial carbonates and organic matter that is accompanied by a period of increased global temperature. This event is known as the Paleocene-Eocene Thermal Maximum (PETM; Kennett and Stott, 1991). One hypothesis for the source of this low $\delta^{13} \mathrm{C}$ carbon is thermal alteration of organic rich sediments that was caused 
by rift-related intrusions associated with the North Atlantic Magmatic Province (Svensen et al., 2004). Such heating would cause release of carbon, and potentially other elements, through conduits that connect the metamorphic aureoles to the paleo-seafloor.

One way to test this hypothesis is to examine other isotope systems and concentrations of elements that may have been released with carbon from these hydrothermal vent complexes. In this chapter, I examine concentrations of major and trace elements, as well as lead isotopes to determine whether they are consistent with the thermal alteration hypothesis for the CIE.

Major and trace element analysis is used to investigate whether enrichment pattern of elements correlate with magmatic and/or organic-rich sediment sources. For instance, enrichments in elements such as mercury or tellurium might indicate magmatic outgassing. These results could have the potential to guide additional investigations into elemental and isotope systems that could help identify the cause(s) of the PETM.

The U-Th-Pb isotope system may provide additional clues on the source of isotopically light carbon. Organic-rich sediments are enriched in $\mathrm{U}$ relative to Th and $\mathrm{Pb}$. Radioactive ${ }^{235} \mathrm{U}$ and ${ }^{238} \mathrm{U}$ decay to stable ${ }^{207} \mathrm{~Pb}$ and ${ }^{206} \mathrm{~Pb}$, respectively. If the carbon isotope excursion was caused in part by contact metamorphism of organic-rich sediments, and if this release was accompanied by release of $\mathrm{Pb}$ from sediments to the water column, we would expect to find excursions to elevated ${ }^{206} \mathrm{~Pb} /{ }^{204} \mathrm{~Pb}$ and ${ }^{207} \mathrm{~Pb} /{ }^{204} \mathrm{~Pb}$ ratios in marine sediments during the PETM, particularly in the seawater-derived (i.e. hydrogenous) component of the bulk sediment. ${ }^{232} \mathrm{Th}$, which decays to ${ }^{208} \mathrm{~Pb}$, is not enriched in organic-rich sediments relative to continental crust, and would therefore not cause elevated ${ }^{208} \mathrm{~Pb} /{ }^{204} \mathrm{~Pb}$ ratios relative to average crustal material. 


\subsection{Methods}

\subsubsection{Samples}

Twelve sediment samples from the Deep Sea Drilling Project (DSDP) Site 549 spanning the PETM were obtained from Greg Ravizza (University of Hawai'i at Manoa). Site 549 is located in the North Atlantic $\left(49^{\circ} 05.28^{\prime} \mathrm{N}, 13^{\circ} 05.88^{\prime} \mathrm{W}\right)$ at $2525 \mathrm{~m}$ water depth and the sediments consist of red to buff colored clays and nanofossiliferous ooze (Barker et al., 1988). This site was selected owing to its location in the North Atlantic. Due to the short residence time of $\mathrm{Pb}$ in the oceans (Chow and Patterson, 1962; Craig et al., 1973), Pb released from the North Atlantic Magmatic Province (NAMP) would most likely be primarily deposited close to the source in the North Atlantic. Additionally, previous studies have demonstrated that this core records the carbon isotope excursion (CIE) of the PETM (Aubry, 1998; Stott et al., 1996) - albeit at low resolution - as well as the Os isotope excursion of seawater (Ravizza et al., 2001).

In addition to the DSDP Site 549 samples, 15 samples from ODP Site 690, also spanning the PETM, were provided by Heather Stoll (Universidad de Oviedo, Spain). ODP 690 is located in the South Atlantic sector of the Southern Ocean $\left(65^{\circ} 09.63 \mathrm{~S}, 1^{\circ} 12.30^{\prime} \mathrm{E}\right)$ at $2925 \mathrm{~m}$ water depth and consists of carbonate-rich nanofossil ooze, which transitions to clay during the PETM (Barker et al., 1988). This site was selected due to the large number of previous studies which have examined the PETM in this core (e.g. Gibbs et al., 2010; Vonhof et al., 2011; Farley and Eltgroth, 2003; Röhl et al., 2000; Kelly et al., 2010; Jiang and Wise, 2009; Robinson et al., 2009; Raffi et al., 2009; Röhl et al., 2007; Stoll and Bains, 2003; Kawahata and Ishizuka, 2000). In addition, the location far from the North Atlantic should allow for differentiation between local and global changes to the $\mathrm{Pb}$ isotopic composition over this time period. 


\subsubsection{Major and trace element analysis}

Samples from DSDP Site 549 were analyzed for major and trace elements at the SARM (Service d'Analyse des Roches et des Minéraux) laboratory (Nancy, France), an analytical research facility that specializes in geologic samples. Prior to analysis, the salt content of the samples was estimated to ensure the chloride content was below levels that cause interferences during ICPMS analysis at the SARM laboratory. $1.99 \mathrm{~g}$ of sample 16R-5, 67-71 was weighed, washed with Milli-Q water and ultrasonicated to allow the salts from the sediment to dissolve in the water, and then centrifuged. The conductivity of the resulting fluid was compared to the conductivity of Milli-Q water and a seawater sample (as a blank and known reference, respectively) to determine the weight content of salt in the sediment. The salt content was found to be within tolerance ( $0.85 \mathrm{wt} . \%)$ of the SARM lab. A small amount (between $1.18 \mathrm{~g}$ and 1.79 g) of each sample was ground using an agate mortar and pestle, then placed in a small plastic vial for shipping to SARM. The mortar and pestle was cleaned between samples by grinding clean quartz sand.

Trace element analysis was performed at SARM using inductively coupled plasma mass and optical emission spectrometry. Major elements were analyzed at SARM by X-ray fluorescence (XRF) and are reported as oxides as percentage (by weight) of the total sample. Uncertainties in the measurements vary according to element concentrations and are based on repeat analyses of standards.

\subsubsection{Lead isotope analysis}

Lead isotopic compositions were measured for both the DSDP 549 and ODP 690 samples on the bulk sediment after dissolution. Approximately $100 \mathrm{mg}$ of each sample were carefully weighed into clean $7 \mathrm{ml}$ Savillex Teflon beakers. Three $\mathrm{ml}$ of concentrated nitric acid, produced 
in-house by sub-boiling distillation in a PicoTrace still, was added very slowly to avoid any sample loss during carbonate dissolution. An additional $1 \mathrm{ml}$ of ultraclean (PicoTrace) concentrated hydrochloric acid $(\mathrm{HCl})$ was added, and the beakers were closed and digested at $170^{\circ} \mathrm{C}$ for a minimum of 24 hours. Samples were then dried slowly at low temperature before 2 $\mathrm{ml}$ of $6 \mathrm{~N} \mathrm{HCl}$ was added to the moist residue. Samples were digested in a closed Teflon beaker overnight at $150^{\circ} \mathrm{C}$ and then dried again. One $\mathrm{ml}$ of Seastar concentrated hydrobromic acid (HBr) was added and the samples were immediately dried. Samples dissolved in $1 \mathrm{ml}$ of $0.5 \mathrm{~N}$ $\mathrm{HBr}$ were twice passed through columns with $1 \mathrm{ml}$ AG 1x8 (100-200 mesh, Bio-Rad) resin, and $\mathrm{Pb}$ was eluted with $1 \mathrm{ml}$ of $6 \mathrm{~N} \mathrm{HCl}$.

High-precision $\mathrm{Pb}$ isotope analysis employed a procedure that uses thallium isotopes to correct for instrumental mass bias on a multi-Faraday ICPMS (ThermoFisher Neptune) in the WHOI ICPMS Facility (Hart and Ball, 2004). This method achieves external precision (2 s.d., 37 analyses of NBS 981 on 14 separate days over a period of six months) of 80 ppm for ${ }^{206} \mathrm{~Pb} /{ }^{204} \mathrm{~Pb}$ and $94 \mathrm{ppm}$ for ${ }^{207} \mathrm{~Pb} /{ }^{204} \mathrm{~Pb}$.

Uranium, thorium, and lead concentrations were also determined to correct for radiogenic ingrowth that occurred between the PETM and the present. This was accomplished using isotope dilution. Samples were spiked with both a mixed ${ }^{208} \mathrm{~Pb}$ and ${ }^{235} \mathrm{U}$ spike as well as a ${ }^{230} \mathrm{Th}$ and ${ }^{235} \mathrm{U}$ spike, then dissolved as described above. Approximately half of the dissolved material was redissolved in $\mathrm{HBr}$ and passed through columns to isolate the $\mathrm{Pb}$ as described above. The remaining precipitate was redissolved in $0.5 \mathrm{ml}$ concentrated $\mathrm{HCl}$. Iron co-precipitation was performed by titrating the acidic solution with ammonium hydroxide to form Fe oxyhydrates. These solids were centrifuged, washed, and redissolved in $4 \mathrm{ml}$ of concentrated nitric acid. The

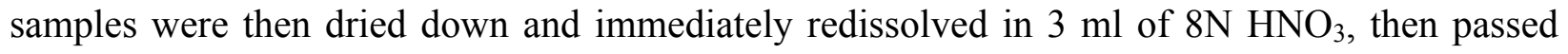


through columns with $1 \mathrm{ml} \mathrm{AG1x8} \mathrm{(100-200} \mathrm{mesh,} \mathrm{Bio-Rad)} \mathrm{resin.} \mathrm{Thorium} \mathrm{was} \mathrm{eluted} \mathrm{with}$ $12.2 \mathrm{ml}$ of concentrated $\mathrm{HCl}$, followed by $12 \mathrm{ml}$ of $0.12 \mathrm{~N} \mathrm{HCl}$ to elute $\mathrm{U}$.

\subsection{Results}

\subsubsection{Major and trace elements}

In order to account for the effects of variable sediment accumulation rates, redistribution and carbonate dissolution on the raw element concentrations, raw elemental concentrations of DSDP Site 549 sediments were first normalized to "immobile" trace elements $\mathrm{Zr}$ and $\mathrm{TiO}_{2}$ (Peterson, 1983) that are associated with the detrital silicate fraction of the sediment and then plotted versus depth in the sediment column.

Treated this way, the majority of the trace elements analyzed (Be, Bi, Ce, Cr, Ge, Hf, Mo, $\mathrm{Nb}, \mathrm{Pb}, \mathrm{Sc}, \mathrm{Sn}, \mathrm{Ta}, \mathrm{Th}, \mathrm{U}$, and $\mathrm{W}$ ) do not change significantly over the depth interval sampled when normalized to $\mathrm{Zr}$ and $\mathrm{TiO}_{2}$. Tungsten does show one anomalously high concentration at the second deepest depth sampled, but this appears to be an outlier, as no other sample showed significant deviation.

When normalized to $\mathrm{Zr}$ and $\mathrm{TiO}_{2}$, several elements (Co, Dy, Er, Eu, Gd, Ho, $\mathrm{La}, \mathrm{Lu}, \mathrm{Nd}$, $\mathrm{Ni}, \mathrm{Pr}, \mathrm{Sm}, \mathrm{Tb}, \mathrm{Tm}, \mathrm{Y}, \mathrm{Yb}, \mathrm{V}$, and $\mathrm{Zn}$ ) display enrichment prior to the PETM, at the three deepest depths sampled. Cobalt deviates the most from the normalized PETM and post-PETM concentrations at the deepest depth (Figure 3.1). This seems to be a relatively common phenomenon among the elements analyzed, and is more pronounced in the Zr normalized data than in those normalized to $\mathrm{TiO}_{2}$. The prevalence of this phenomenon seems to indicate that these features that are artifacts of the normalization. However it cannot be ruled out that these elements are enriched in sediments deposited prior to the PETM. 
Osmium data (taken from Ravizza et al., 2001) also fall into this category of enrichment prior to the PETM, but given the relatively large uncertainties, they show no significant change across the PETM. Rhenium data (also from Ravizza et. al, 2001) are incomplete, the uncertainties are relatively large, the concentrations are very low $(\sim 10 \mathrm{pg} / \mathrm{g})$, and the data is very noisy, making it difficult to draw useful conclusions from these data. From the available data, however, it seems that when normalized to $\mathrm{TiO}_{2}$, neither Os nor Re change significantly across the PETM.

Cadmium shows a significant depletion during the PETM, reaching levels below the analytical detection limit. This drop in concentration is likely due to the dissolution of carbonates, a significant host phase of Cd, during the PETM (presumed to be caused by acidification of seawater from the addition of carbon dioxide).

Similar to $\mathrm{Cd}, \mathrm{Sr}$ also displays a pronounced decrease, peaking before the carbon isotope peak (Figure 3.2). The cause of this depletion is also likely related to carbonate dissolution. Diffusion of acidic seawater into sediments may dissolve carbonates deposited prior to the PETM. Copper also displays a decrease during the PETM when normalized to $\mathrm{Zr}$ and $\mathrm{TiO}_{2}$, but the data are noisy, and the decrease was much smaller than the decrease seen in $\mathrm{Sr}$ and $\mathrm{Cd}$. Additionally, $\mathrm{Cu}$ does not seem to express a pattern of depletion at the PETM in the raw data.

Arsenic is the only element that shows significant enrichment across the PETM after normalization to $\mathrm{TiO}_{2}$ and $\mathrm{Zr}$ (Figure 3.3). Interestingly, the As peak precedes the PETM carbon isotope peak slightly in the normalized data (the carbon isotope peak is at $338.73 \mathrm{mbsf}$, while the As peak is at $338.96 \mathrm{mbsf}$ ), and also recovers more slowly. Arsenic, due to its similarity to sulfur, can be incorporated into sulfur-bearing minerals such as authigenic pyrite (Smedley and Kinniburgh, 2001) that forms under reducing conditions. Thermal alteration of pyrite may have 
thus released arsenic into the seawater at the PETM. However, As is also released in volcanic eruptions and can be adsorbed onto hydrous Fe-Mn oxides (Smedley and Kinniburgh, 2002). As arsenic is mono-isotopic, isotope systematics cannot be used to determine the source of the arsenic enrichment.

Barium is enriched during the PETM, but the correlation with the PETM is less clear than As, with the concentrations highly variable before and after the PETM (Figure 3.4). In fact, barium's lowest normalized concentration occurs just prior to the PETM, while its highest concentration is reached during the carbon isotope recovery. Thus it is not clear whether the variations in $\mathrm{Ba}$ concentration are directly related to the trigger mechanism for the PETM, and instead may be a byproduct of another process occurring at that time.

A few other elements have small, but statistically significant, enrichments at the PETM when normalized to $\mathrm{Zr}$ and $\mathrm{TiO}_{2}$. These elements include $\mathrm{Cs}, \mathrm{Ga}, \mathrm{Rb}$, and $\mathrm{Sb}$. However, these changes are much smaller than the changes seen in As.

Silicon shows no change across the sampled interval. Magnesium and sodium do display slight enrichments prior to the PETM, similar to the pattern seen in many of the trace elements such as cobalt.

Calcium is very significantly depleted during the PETM, reaching less than $1 \mathrm{wt} . \%$ at the peak of the carbon isotope excursion. This is consistent with the extensive dissolution of carbonate observed previously for this time period.

Manganese is also significantly depleted during the PETM, especially when normalized to $\mathrm{Zr}$ and $\mathrm{TiO}_{2}$ (Figure 3.5). However, the peak of Mn depletion occurs significantly before the PETM carbon isotope peak (at the $3^{\text {rd }}$ deepest sampled point as opposed to the carbon isotope peak which occurs at the $5^{\text {th }}$ deepest sampled point) as well as prior to the peak in As (the $4^{\text {th }}$ 
deepest sampled point). Thus the correlation between Mn concentrations and the PETM is unclear. However, there are significant changes in Mn concentrations during the sampled interval.

Phosphorous shows minimal changes across the PETM, but the resolution of the data is low due to very low concentrations that reach a maximum of $0.2 \mathrm{wt} . \%$. Therefore, many of the differences are likely caused by the normalization procedure, and it is unlikely that sedimentary P concentrations changed significantly across the PETM.

The timing of the enrichment/depletion peaks for each element is plotted against the Enrichment Factor (defined here as the magnitude of the highest concentration divided by the post-PETM value, taken as the value at the shallowest depth in the sediment core) for each major and trace element (Figure 3.6). This diagram highlights elements that display the highest degree of enrichment during the PETM.

\subsubsection{Lead isotope analysis}

Lead isotopic compositions were age-corrected to the PETM using the concentrations of $\mathrm{U}$ and $\mathrm{Pb}$ measured by isotope dilution (Figure 3.7). Thorium concentrations measured by isotope dilution yield values between 15 and $50 \mu \mathrm{g} / \mathrm{g}$. Such values are much too high to be reasonable for marine sediments, thus pointing to incomplete spike-sample equilibration. ${ }^{208} \mathrm{~Pb}$ was therefore age-corrected using the Th concentrations measured by SARM that range from 4.5 to $10 \mu \mathrm{g} / \mathrm{g}$.

In DSDP 549, both ${ }^{207} \mathrm{~Pb} /{ }^{204} \mathrm{~Pb}$ and ${ }^{208} \mathrm{~Pb} /{ }^{204} \mathrm{~Pb}$ increased at the PETM, coincident with the peak in the CIE. ${ }^{206} \mathrm{~Pb} /{ }^{204} \mathrm{~Pb}$, however, exhibits the opposite trend, decreasing significantly at the PETM. In ODP $690,{ }^{206} \mathrm{~Pb} /{ }^{204} \mathrm{~Pb},{ }^{207} \mathrm{~Pb} /{ }^{204} \mathrm{~Pb}$, and ${ }^{208} \mathrm{~Pb} /{ }^{204} \mathrm{~Pb}$ all increase at the peak of the 
PETM. However, these increases are all very small compared to much larger changes occurring deeper in the core.

The two cores cover significantly different time intervals. In order to compare the two, the overlapping portions were plotted on the same time/depth axis, using the peak of the PETM CIE as an anchor point (Figure 3.8; Farley and Eltgroth, 2003; Ravizza et al., 2001). ${ }^{207} \mathrm{~Pb} /{ }^{204} \mathrm{~Pb}$ and ${ }^{208} \mathrm{~Pb} /{ }^{204} \mathrm{~Pb}$ have very similar trends over the studied time interval, while the trend in ${ }^{206} \mathrm{~Pb} /{ }^{204} \mathrm{~Pb}$ differed significantly, with samples from the ODP 690 core showing an overall increase in the ratio whereas those from the DSDP 549 core first decrease then increase.

Radiogenic lead isotopes, normalized to the non-radiogenic ${ }^{204} \mathrm{~Pb}$ are plotted against each other to constrain possible compositions of the end member causing the isotopic changes at the PETM (Figures 3.9 and 3.10). Linear correlations were high for ${ }^{207} \mathrm{~Pb} /{ }^{204} \mathrm{~Pb}$ vs. ${ }^{206} \mathrm{~Pb} /{ }^{204} \mathrm{~Pb}$ and ${ }^{207} \mathrm{~Pb} /{ }^{204} \mathrm{~Pb}$ vs. ${ }^{208} \mathrm{~Pb} /{ }^{204} \mathrm{~Pb} \quad\left(\mathrm{R}^{2}\right.$ of 0.69 and 0.45 respectively), but low for ${ }^{208} \mathrm{~Pb} /{ }^{204} \mathrm{~Pb}$ vs. ${ }^{206} \mathrm{~Pb} /{ }^{204} \mathrm{~Pb}\left(\mathrm{R}^{2}\right.$ of 0.16$)$ in the DSDP 549 core. Correlations are highest for ${ }^{207} \mathrm{~Pb} /{ }^{204} \mathrm{~Pb}$ vs. ${ }^{208} \mathrm{~Pb} /{ }^{204} \mathrm{~Pb}\left(\mathrm{R}^{2}\right.$ of 0.87$)$ in the ODP 690 core, but are also reasonably high for ${ }^{207} \mathrm{~Pb} /{ }^{204} \mathrm{~Pb}$ vs. ${ }^{206} \mathrm{~Pb} /{ }^{204} \mathrm{~Pb}$ and ${ }^{208} \mathrm{~Pb} /{ }^{204} \mathrm{~Pb}$ vs. ${ }^{206} \mathrm{~Pb} /{ }^{204} \mathrm{~Pb}\left(\mathrm{R}^{2}\right.$ of 0.53 and 0.57 respectively).

\subsection{Discussion}

\subsubsection{Major and trace elements of DSDP 549 sediments}

The majority of elements examined show little to no relevant changes across the PETM. Further investigation should focus on elements that demonstrate significant or unexplained normalized concentration changes across the PETM, especially As. The correlation between the normalized concentrations of these elements and the timing of the PETM is high, as are the relative concentration changes, indicating that these changes in concentration may have been due to processes occurring during the PETM. 
Other elements ( $\mathrm{Cs}, \mathrm{Ga}, \mathrm{Rb}, \mathrm{Sb}, \mathrm{Al}$, and $\mathrm{Fe}$ ) display slight enrichments over the PETM when normalized to $\mathrm{Zr}$ and $\mathrm{TiO}_{2}$, similar to As, but smaller in magnitude, and therefore may merit further investigation.

Finally, there are elements whose concentrations illustrate significant changes, but the timing of these changes is not well correlated with the PETM. These elements include Mn, Ba, and $\mathrm{Cu}$. Understanding what drove the changes in these concentrations may prove useful, but due to the poor correlations with the PETM, they are unlikely to reveal insights into potential trigger mechanisms of the CIE. It is possible, however, that the lack of temporal correlation with the PETM may be due to post-depositional processes, such as diffusion or bioturbation which may mix the elements through the sediment column.

\subsubsection{Lead at the PETM}

The patterns of lead isotope changes across the PETM are inconsistent with a source of lead that is derived from organic-rich sediments (Figure 3.11). Lead from such a source would have elevated ${ }^{206} \mathrm{~Pb} /{ }^{204} \mathrm{~Pb}$ and ${ }^{207} \mathrm{~Pb} /{ }^{204} \mathrm{~Pb}$, but not elevated ${ }^{208} \mathrm{~Pb} /{ }^{204} \mathrm{~Pb}$ relative to continental crust and detrital material. Instead, $\mathrm{Pb}$ isotopic evidence from DSDP 549 indicates a different source of $\mathrm{Pb}$ with a lower ${ }^{206} \mathrm{~Pb} /{ }^{204} \mathrm{~Pb}$ and a higher ${ }^{207} \mathrm{~Pb} /{ }^{204} \mathrm{~Pb}$ and ${ }^{208} \mathrm{~Pb} /{ }^{204} \mathrm{~Pb}$, such as $\mathrm{Pb}$ from average continental crust. Additionally, the relative changes in the isotopic ratios observed at the PETM in the ODP 690 core were significantly different than those observed in the DSDP 549 core, especially in ${ }^{206} \mathrm{~Pb} /{ }^{204} \mathrm{~Pb}$. This indicates that the mechanism(s) of the $\mathrm{Pb}$ isotope excursions lack(s) global reach and the isotope excursions instead represent local processes. Lead has a short residence time in seawater (Chow and Patterson, 1962; Craig et al., 1973) and changes in the isotope composition likely represent a local source of lead to the ocean. Addition of continental crustal lead with an isotopic composition akin to that estimated by Allegre et al. 
(1996, blue diamond in Fig. 3.11) is consistent with the change in isotope ratios observed. One possible explanation for the change in isotopic ratios is an increase in the amount of runoff delivering lead with a crustal isotope composition. However it is impossible to distinguish between a change in the flux of $\mathrm{Pb}$ from the crustal source and a change in the isotopic composition of the source. Additionally, I did not study the extent of variations in sedimentary $\mathrm{Pb}$ isotope variations outside the PETM, and therefore lack the ability to judge whether the observed variations are consistent with short-term variations in sedimentary $\mathrm{Pb}$ isotope composition during background (i.e. non-PETM) sedimentation.

It is also important to remember that all analyses reported in this chapter were carried out on bulk sediments. The bulk $\mathrm{Pb}$ signature is likely a mix of detrital as well as hydrogenous (i.e., seawater-derived) lead. Lead released from organic-rich sediments during thermal alteration would be dissolved in seawater and would only affect the hydrogenous component of the bulk sediment. Should the $\mathrm{Pb}$ signal in the bulk sediment be dominated by the detrital fraction, the bulk signature would mask small changes in the isotope composition of the hydrogenous lead reservoir. I attempt to estimate the fraction of the $\mathrm{Pb}$ inventory that is associated with hydrogenous $\mathrm{Pb}$ by normalizing bulk $\mathrm{Pb}$ concentrations to the concentrations of $\mathrm{Zr}, \mathrm{Ti}$, and $\mathrm{Th}$, all of which are assumed to be associated exclusively with the detrital fraction. Concentrations of these elements in the bulk samples are divided by the concentrations measured in the average upper continental crust (McLennan, 2001), and multiplied by the $\mathrm{Pb}$ concentrations in average continental crust to estimate the detrital fraction of $\mathrm{Pb}$. The remainder of the total sedimentary $\mathrm{Pb}$ is assumed to be hydrogenous. Estimates of the hydrogenous fraction using average upper continental crust range from $0-57 \%$, with an average of $26 \%$. Estimates following the same procedure, but using Post-Archean Australian Shale (McLennan, 2001), range from 47-55\% 
hydrogenous. Thus a significant portion of the lead measured in this study is likely detrital, and may therefore obscure any hydrogenous signal.

\subsection{Conclusions}

In this chapter, I examine evidence for the trigger mechanism of the CIE at the PETM using data collected from two marine sediment cores: DSDP Site 549 and ODP Site 690. The majority of major and trace elements analyzed from sediments from DSDP Site 549 show no

change in concentrations across the PETM. Arsenic, however, increases across the PETM. Interestingly, the increase in As concentrations precedes the CIE and the recovery to pre-PETM values is much slower. Unfortunately, As isotopes cannot be used to determine the source of the additional As, because As is mono-isotopic. Lead isotope compositions in bulk sediments do not lend support to the hypothesis that lead was released to seawater during thermal alteration of organic-rich sediments at the PETM. However, large portions of the total lead (as much as 50$75 \%$ ) are derived from detrital sources, which may obscure any hydrogenous signal of lead released and re-precipitated from organic-rich sediments. Alternatively, the short residence time of $\mathrm{Pb}$ in the oceans may result in any $\mathrm{Pb}$ mobilized during thermal alteration being locally redeposited and not showing up in cores far from the intrusion site. Thus, while not consistant with a source of $\mathrm{Pb}$ from organic-rich sediments, the $\mathrm{Pb}$ isotope record does not allow me to rule out the hypothesis that a significant amount of carbon came from such sediments at the PETM. 


\begin{tabular}{cccccccccccccc}
\hline Core Designation & $\begin{array}{c}\text { Depth } \\
\text { (mbsf) }\end{array}$ & $\delta^{13} \mathrm{C}$ & $\begin{array}{c}\mathrm{As} \\
\mu \mathrm{g} / \mathrm{g}\end{array}$ & $\begin{array}{c}\mathrm{Ba} \\
\mu \mathrm{g} / \mathrm{g}\end{array}$ & $\begin{array}{c}\mathrm{Be} \\
\mu \mathrm{g} / \mathrm{g}\end{array}$ & $\begin{array}{c}\mathrm{Bi} \\
\mu \mathrm{g} / \mathrm{g}\end{array}$ & $\begin{array}{c}\mathrm{Cd} \\
\mu \mathrm{g} / \mathrm{g}\end{array}$ & $\begin{array}{c}\mathrm{Ce} \\
\mu \mathrm{g} / \mathrm{g}\end{array}$ & $\begin{array}{c}\mathrm{Co} \\
\mu \mathrm{g} / \mathrm{g}\end{array}$ & $\begin{array}{c}\mathrm{Cr} \\
\mu \mathrm{g} / \mathrm{g}\end{array}$ & $\begin{array}{c}\mathrm{Cs} \\
\mu \mathrm{g} / \mathrm{g}\end{array}$ & $\begin{array}{c}\mathrm{Cu} \\
\mu \mathrm{g} / \mathrm{g}\end{array}$ & $\begin{array}{c}\mathrm{Dy} \\
\mu \mathrm{g} / \mathrm{g}\end{array}$ \\
\hline 16R-4W-68-72 & 336.68 & 1.457 & 6.959 & 799.2 & 1.399 & 0.197 & 0.408 & 36.47 & 13.45 & 52.82 & 3.805 & 31.29 & 2.806 \\
16R-4W-98-102 & 336.98 & 1.388 & 4.599 & 1016 & 1.279 & 0.177 & 0.442 & 35.6 & 12.9 & 52.13 & 3.635 & 38.4 & 2.72 \\
16R-5W-11-15 & 337.29 & 1.192 & 7.544 & 1010 & 1.429 & 0.186 & 0.311 & 41.54 & 14.38 & 57 & 4.227 & 21.66 & 3.075 \\
16R-5W-29-32 & 337.47 & 1.147 & 8.116 & 1075 & 1.406 & 0.191 & 0.287 & 41.11 & 14.29 & 59.08 & 4.223 & 30.15 & 3.01 \\
16R-5W-67-71 & 337.85 & 0.637 & 7.338 & 1133 & 1.548 & 0.205 & 0.245 & 45.33 & 16.05 & 71.68 & 5.114 & 27.99 & 3.228 \\
16R-5W-99-103 & 338.17 & -0.056 & 21.13 & 2100 & 2.092 & 0.369 & 0.128 & 54.15 & 16.84 & 77.15 & 7.22 & 18.28 & 3.397 \\
16R-5W-129-133 & 338.47 & -0.721 & 27.01 & 2025 & 2.385 & 0.384 & $<$ L.D. & 66.49 & 19.84 & 89.76 & 8.639 & 27.77 & 4.413 \\
16R-6W-5-8 & 338.73 & -2.816 & 24.46 & 1885 & 2.635 & 0.371 & $<$ L.D. & 74.56 & 24.18 & 100.3 & 9.938 & 19.03 & 4.83 \\
16R-6W-28-33 & 338.96 & -0.473 & 31.72 & 505.7 & 2.711 & 0.333 & $<$ L.D. & 71.3 & 22.33 & 97.46 & 8.794 & 31.35 & 4.964 \\
16R-6W-65-69 & 339.33 & 1.879 & 13.75 & 1203 & 1.986 & 0.327 & 0.14 & 61.66 & 29.05 & 81.24 & 6.049 & 37.25 & 4.582 \\
16R-6W-98-102 & 339.66 & 2.293 & 6.601 & 965.3 & 1.501 & 0.28 & 0.229 & 46.63 & 27.31 & 65.75 & 4.174 & 38.73 & 4.012 \\
16R-6W-129-131 & 339.97 & 2.191 & 6.655 & 1130 & 1.342 & 0.274 & 0.321 & 41.28 & 25.81 & 58.08 & 3.773 & 24.04 & 3.452 \\
Typical & & & & & & & & & & & & \\
uncertainties & & & $10 \%$ & $5 \%$ & $25 \%$ & $25 \%$ & $25 \%$ & $5 \%$ & $10 \%$ & $5 \%$ & $10 \%$ & $10 \%$ & $5 \%$ \\
\hline
\end{tabular}




\begin{tabular}{cccccccccccccc}
\hline Core Designation & $\mathrm{Er}$ & $\mathrm{Eu}$ & $\mathrm{Ga}$ & $\mathrm{Gd}$ & $\mathrm{Ge}$ & $\mathrm{Hf}$ & $\mathrm{Ho}$ & $\mathrm{In}$ & $\mathrm{La}$ & $\mathrm{Lu}$ & $\mathrm{Mo}$ & $\mathrm{Nb}$ \\
& $\mu \mathrm{g} / \mathrm{g}$ & $\mu \mathrm{g} / \mathrm{g}$ & $\mu \mathrm{g} / \mathrm{g}$ & $\mu \mathrm{g} / \mathrm{g}$ & $\mu \mathrm{g} / \mathrm{g}$ & $\mu \mathrm{g} / \mathrm{g}$ & $\mu \mathrm{g} / \mathrm{g}$ & $\mu \mathrm{g} / \mathrm{g}$ & $\mu \mathrm{g} / \mathrm{g}$ & $\mu \mathrm{g} / \mathrm{g}$ & $\mu \mathrm{g} / \mathrm{g}$ & $\mu \mathrm{g} / \mathrm{g}$ & $\mu \mathrm{g} / \mathrm{g}$ \\
\hline 16R-4W-68-72 & 1.569 & 0.832 & 10.5 & 3.225 & 1.061 & 1.808 & 0.553 & $<$ L.D. & 21.04 & 0.235 & 0.771 & 5.924 & 18.5 \\
16R-4W-98-102 & 1.524 & 0.789 & 10.05 & 3.096 & 0.988 & 1.671 & 0.545 & $<$ L.D. & 20.54 & 0.229 & 0.574 & 5.543 & 17.88 \\
16R-5W-11-15 & 1.671 & 0.918 & 11.42 & 3.469 & 1.052 & 2.118 & 0.607 & $<$ L.D. & 23.22 & 0.252 & 0.777 & 7.177 & 20.41 \\
16R-5W-29-32 & 1.646 & 0.875 & 11.52 & 3.41 & 1.234 & 2.136 & 0.602 & $<$ L.D. & 22.71 & 0.259 & 0.771 & 6.764 & 19.93 \\
16R-5W-67-71 & 1.754 & 0.931 & 13.17 & 3.6 & 1.28 & 2.428 & 0.64 & $<$ L.D. & 24.1 & 0.274 & 0.731 & 7.66 & 21.06 \\
16R-5W-99-103 & 1.862 & 0.997 & 17.33 & 3.905 & 1.593 & 2.428 & 0.678 & 0.082 & 29.65 & 0.295 & 1.196 & 8.452 & 24.06 \\
16R-5W-129-133 & 2.531 & 1.199 & 20.76 & 4.803 & 1.917 & 2.94 & 0.883 & 0.086 & 37.18 & 0.396 & 1.402 & 10.53 & 28.93 \\
16R-6W-5-8 & 2.681 & 1.347 & 23.41 & 5.408 & 1.989 & 3.133 & 0.942 & 0.102 & 41.5 & 0.425 & 1.389 & 11.83 & 32.95 \\
16R-6W-28-33 & 2.691 & 1.425 & 20.78 & 5.519 & 1.96 & 3.587 & 0.965 & 0.089 & 37.51 & 0.411 & 1.358 & 12.2 & 33.23 \\
16R-6W-65-69 & 2.412 & 1.386 & 16.16 & 5.317 & 1.574 & 2.756 & 0.882 & $<$ L.D. & 31.63 & 0.35 & 0.957 & 9.121 & 30.56 \\
16R-6W-98-102 & 2.185 & 1.149 & 12.13 & 4.443 & 1.12 & 2.129 & 0.78 & $<$ L.D. & 27.82 & 0.315 & 0.849 & 6.874 & 24.6 \\
16R-6W-129-131 & 1.927 & 1.005 & 10.54 & 3.971 & 1.047 & 1.649 & 0.68 & $<$ L.D. & 25.55 & 0.284 & $<$ L.D. & 5.655 & 22.16 \\
Typical & & & & & & & & & & & & \\
uncertainties & 5 & $5 \%$ & $5 \%$ & $5 \%$ & $8 \%$ & $10 \%$ & $10 \%$ & $100 \%$ & $5 \%$ & $5 \%$ & $25 \%$ & $10 \%$ & $5 \%$ \\
\hline
\end{tabular}




\begin{tabular}{|c|c|c|c|c|c|c|c|c|c|c|c|c|c|}
\hline Core Designation & $\begin{array}{c}\mathrm{Ni} \\
\mu \mathrm{g} / \mathrm{g}\end{array}$ & $\begin{array}{c}\mathrm{Pb} \\
\mu \mathrm{g} / \mathrm{g}\end{array}$ & $\begin{array}{c}\mathrm{Pr} \\
\mu \mathrm{g} / \mathrm{g}\end{array}$ & $\begin{array}{c}\mathrm{Rb} \\
\mu \mathrm{g} / \mathrm{g}\end{array}$ & $\begin{array}{c}\mathrm{Sc} \\
\mu \mathrm{g} / \mathrm{g}\end{array}$ & $\begin{array}{c}\mathrm{Sb} \\
\mu \mathrm{g} / \mathrm{g}\end{array}$ & $\begin{array}{c}\mathrm{Sm} \\
\mu \mathrm{g} / \mathrm{g}\end{array}$ & $\begin{array}{c}\mathrm{Sn} \\
\mu \mathrm{g} / \mathrm{g}\end{array}$ & $\begin{array}{c}\mathrm{Sr} \\
\mu \mathrm{g} / \mathrm{g}\end{array}$ & $\begin{array}{c}\mathrm{Ta} \\
\mu \mathrm{g} / \mathrm{g}\end{array}$ & $\begin{array}{c}\mathrm{Tb} \\
\mu \mathrm{g} / \mathrm{g}\end{array}$ & $\begin{array}{c}\text { Th } \\
\mu \mathrm{g} / \mathrm{g}\end{array}$ & $\begin{array}{c}\mathrm{Tm} \\
\mu \mathrm{g} / \mathrm{g}\end{array}$ \\
\hline $16 R-4 W-68-72$ & 41.29 & 9.662 & 4.402 & 59.18 & 9.93 & 0.453 & 3.6 & 1.168 & 690.3 & 0.482 & 0.481 & 4.686 & 0.232 \\
\hline 16R-4W-98-102 & 38.46 & 9.8571 & 4.289 & 56.5 & 9.49 & 0.353 & 3.488 & 1.147 & 737.8 & 0.454 & 0.468 & 4.482 & 0.227 \\
\hline $16 R-5 W-11-15$ & 43.18 & 12.4305 & 4.93 & 65.22 & 10.34 & 0.484 & 3.995 & 1.294 & 678.6 & 0.53 & 0.524 & 5.215 & 0.254 \\
\hline $16 R-5 W-29-32$ & 43.33 & 12.6638 & 4.797 & 65.33 & 10.79 & 0.513 & 3.906 & 1.404 & 693.3 & 0.537 & 0.519 & 5.225 & 0.246 \\
\hline $16 R-5 W-67-71$ & 46.48 & 15.106 & 5.154 & 76.84 & 11.92 & 0.48 & 4.177 & 1.534 & 647.6 & 0.64 & 0.548 & 6.024 & 0.267 \\
\hline 16R-5W-99-103 & 54.5 & 17.1958 & 5.889 & 105.7 & 14.33 & 1.182 & 4.734 & 2.005 & 518.7 & 0.698 & 0.584 & 7.873 & 0.287 \\
\hline $16 R-5 W-129-133$ & 63.56 & 20.047 & 7.136 & 125.8 & 16.58 & 1.329 & 5.604 & 2.368 & 392.5 & 0.883 & 0.735 & 9.181 & 0.382 \\
\hline $16 R-6 W-5-8$ & 76.59 & 23.2531 & 8.08 & 140.8 & 18.42 & 1.393 & 6.329 & 2.702 & 267 & 0.986 & 0.809 & 10.43 & 0.408 \\
\hline $16 R-6 W-28-33$ & 68.93 & 22.0364 & 8.119 & 128.8 & 16.48 & 1.596 & 6.534 & 2.599 & 258.9 & 1.04 & 0.839 & 10.03 & 0.409 \\
\hline $16 R-6 W-65-69$ & 68.28 & 19.0336 & 7.349 & 92.54 & 14.8 & 0.91 & 6.206 & 1.873 & 492 & 0.76 & 0.799 & 8.152 & 0.358 \\
\hline 16R-6W-98-102 & 58.16 & 16.3331 & 6.032 & 64.4 & 12.34 & 0.512 & 4.986 & 1.388 & 630.8 & 0.557 & 0.673 & 5.697 & 0.327 \\
\hline $\begin{array}{c}\text { 16R-6W-129-131 } \\
\text { Typical }\end{array}$ & 53.87 & 13.0929 & 551 & 57.72 & 104 & 0.598 & 445 & 1.292 & 731.9 & 0.464 & 0.59 & 5.069 & 0.287 \\
\hline uncertainties & $5 \%$ & $5 \%$ & $5 \%$ & $5 \%$ & $15 \%$ & $25 \%$ & $5 \%$ & $15 \%$ & $5 \%$ & $15 \%$ & $5 \%$ & $10 \%$ & $10 \%$ \\
\hline
\end{tabular}




\begin{tabular}{cccccccc}
\hline Core Designation & $\mathrm{U}$ & $\mathrm{V}$ & $\mathrm{W}$ & $\mathrm{Y}$ & $\mathrm{Yb}$ & $\mathrm{Zn}$ & $\mathrm{Zr}$ \\
& $\mu \mathrm{g} / \mathrm{g}$ & $\mu \mathrm{g} / \mathrm{g}$ & $\mu \mathrm{g} / \mathrm{g}$ & $\mu \mathrm{g} / \mathrm{g}$ & $\mu \mathrm{g} / \mathrm{g}$ & $\mu \mathrm{g} / \mathrm{g}$ & $\mu \mathrm{g} / \mathrm{g}$ \\
\hline 16R-4W-68-72 & 0.794 & 65.92 & 1.022 & 17.73 & 1.531 & 69.26 & 69.32 \\
16R-4W-98-102 & 0.863 & 87.79 & 0.936 & 17.17 & 1.515 & 65.03 & 63.6 \\
16R-5W-11-15 & 0.886 & 69.8 & 1.151 & 18.74 & 1.662 & 71.3 & 79.78 \\
16R-5W-29-32 & 0.886 & 68.68 & 1.13 & 18.51 & 1.695 & 74.9 & 83.19 \\
16R-5W-67-71 & 1.068 & 93.6 & 1.371 & 18.84 & 1.791 & 76.37 & 90.39 \\
16R-5W-99-103 & 1.246 & 110.4 & 1.651 & 20.06 & 1.973 & 95.83 & 89.73 \\
16R-5W-129-133 & 1.5 & 107.6 & 2.086 & 27.43 & 2.586 & 109.2 & 110.9 \\
16R-6W-5-8 & 1.708 & 123.1 & 2.371 & 28.9 & 2.753 & 117.1 & 117.9 \\
16R-6W-28-33 & 1.701 & 116 & 2.44 & 29.33 & 2.715 & 110.1 & 134.1 \\
16R-6W-65-69 & 1.274 & 156.3 & 2.025 & 25.81 & 2.309 & 105.1 & 99.58 \\
16R-6W-98-102 & 0.922 & 115.6 & 2.685 & 24.63 & 2.084 & 85.17 & 76.08 \\
16R-6W-129-131 & 0.839 & 113.5 & 1.452 & 21.95 & 1.853 & 80.63 & 62.48 \\
Typical & & & & & & & \\
uncertainties & $15 \%$ & $5 \%$ & $15 \%$ & $5 \%$ & $5 \%$ & $10 \%$ & $8 \%$ \\
\hline
\end{tabular}

Table 3.1 SARM trace element data of DSDP Site 549 bulk sediments. Typical uncertainties are provided by SARM and are based on repeat analyses of standards. "< L.D." indicates that the concentrations are below analytical detection limits. 


\begin{tabular}{ccccccccccccc}
\hline Core Designation & $\begin{array}{c}\text { Depth } \\
\text { (mbsf) }\end{array}$ & $\begin{array}{c}\mathrm{SiO}_{2} \\
\mathrm{Wt} . \%\end{array}$ & $\begin{array}{c}\mathrm{Al}_{2} \mathrm{O}_{3} \\
\mathrm{Wt} . \%\end{array}$ & $\begin{array}{c}\mathrm{Fe}_{2} \mathrm{O}_{3} \\
\mathrm{Wt} . \%\end{array}$ & $\begin{array}{c}\mathrm{MnO} \\
\mathrm{Wt} . \%\end{array}$ & $\begin{array}{c}\mathrm{MgO} \\
\mathrm{Wt} . \%\end{array}$ & $\begin{array}{c}\mathrm{CaO} \\
\mathrm{Wt} . \%\end{array}$ & $\begin{array}{c}\mathrm{Na}_{2} \mathrm{O} \\
\mathrm{Wt} . \%\end{array}$ & $\begin{array}{c}\mathrm{K}_{2} \mathrm{O} \\
\text { Wt.\% }\end{array}$ & $\begin{array}{c}\mathrm{TiO}_{2} \\
\text { Wt.\% }\end{array}$ & $\begin{array}{c}\mathrm{P}_{2} \mathrm{O}_{5} \\
\text { Wt.\% }\end{array}$ & $\begin{array}{c}\mathrm{PF} \\
\text { Wt.\% }\end{array}$ \\
\hline 16R-4W-68-72 & 336.68 & 26.15 & 7.82 & 4.06 & 0.17 & 1.36 & 28.37 & 0.82 & 1.47 & 0.40 & 0.14 & 28.76 \\
16R-4W-98-102 & 336.98 & 24.44 & 7.34 & 3.47 & 0.19 & 1.30 & 30.30 & 0.81 & 1.39 & 0.38 & 0.14 & 30.09 \\
16R-5W-11-15 & 337.29 & 29.50 & 8.50 & 4.21 & 0.15 & 1.46 & 25.93 & 0.98 & 1.72 & 0.44 & 0.14 & 27.09 \\
16R-5W-29-32 & 337.47 & 30.03 & 8.40 & 4.25 & 0.17 & 1.44 & 25.06 & 1.00 & 1.73 & 0.44 & 0.13 & 27.17 \\
16R-5W-67-71 & 337.85 & 35.63 & 9.73 & 4.25 & 0.11 & 1.59 & 20.57 & 1.17 & 2.13 & 0.51 & 0.12 & 23.95 \\
16R-5W-99-103 & 338.17 & 41.82 & 12.20 & 5.92 & 0.10 & 1.72 & 13.24 & 1.39 & 2.87 & 0.52 & 0.13 & 19.80 \\
16R-5W-129-133 & 338.47 & 48.97 & 14.53 & 7.23 & 0.11 & 2.05 & 5.84 & 1.46 & 3.29 & 0.64 & 0.20 & 15.18 \\
16R-6W-5-8 & 338.73 & 54.08 & 16.58 & 7.78 & 0.08 & 2.37 & 0.69 & 1.51 & 3.62 & 0.71 & 0.20 & 11.98 \\
16R-6W-28-33 & 338.96 & 55.06 & 14.85 & 7.20 & 0.10 & 2.22 & 1.57 & 1.58 & 3.49 & 0.73 & 0.20 & 12.76 \\
16R-6W-65-69 & 339.33 & 43.88 & 12.03 & 5.65 & 0.06 & 2.09 & 12.22 & 1.40 & 2.52 & 0.58 & 0.16 & 18.90 \\
16R-6W-98-102 & 339.66 & 34.07 & 9.26 & 4.42 & 0.11 & 1.85 & 21.15 & 1.20 & 1.74 & 0.52 & 0.16 & 25.49 \\
16R-6W-129-131 & 339.97 & 29.82 & 8.04 & 3.90 & 0.15 & 1.65 & 25.67 & 1.11 & 1.62 & 0.37 & 0.17 & 27.61 \\
Typical & & & & & & & & & & & \\
uncertainties & & $1 \%$ & $5 \%$ & $2 \%$ & $5 \%$ & $5 \%$ & $5 \%$ & $5 \%$ & $5 \%$ & $10 \%$ & $10 \%$ & \\
\hline
\end{tabular}

Table 3.2 SARM major element analysis of DSDP Site 549 bulk sediments (wt.\%). Typical uncertainties are provided by SARM and are based on repeat analyses of standards. "PF" indicates the loss on ignition. 


\begin{tabular}{|c|c|c|c|c|c|c|c|}
\hline $\begin{array}{c}\text { ODP/DSDP } \\
\text { Site }\end{array}$ & $\begin{array}{l}\text { Depth } \\
\text { (mbsf) }\end{array}$ & ${ }^{206} \mathrm{~Pb} /{ }^{204} \mathrm{~Pb}$ & ${ }^{207} \mathrm{~Pb} /{ }^{204} \mathrm{~Pb}$ & ${ }^{208} \mathrm{~Pb} /{ }^{204} \mathrm{~Pb}$ & $\begin{array}{c}{ }^{206} \mathrm{~Pb} /{ }^{204} \mathrm{~Pb} \\
\text { error }\end{array}$ & $\begin{array}{c}{ }^{207} \mathrm{~Pb} /{ }^{204} \mathrm{~Pb} \\
\text { error } \\
\end{array}$ & $\begin{array}{c}{ }^{208} \mathrm{~Pb} /{ }^{204} \mathrm{~Pb} \\
\text { error }\end{array}$ \\
\hline 690 & 169.48 & 18.9600 & 15.7011 & 38.9285 & 0.0008 & 0.0006 & 0.0013 \\
\hline 690 & 169.88 & 18.9313 & 15.7025 & 38.9635 & 0.0001 & 0.0001 & 0.0001 \\
\hline 690 & 170.16 & 18.9238 & 15.7025 & 38.9876 & 0.0004 & 0.0006 & 0.0016 \\
\hline 690 & 170.25 & 18.9353 & 15.7031 & 38.9967 & 0.0004 & 0.0006 & 0.0016 \\
\hline 690 & 170.3 & 18.9331 & 15.7024 & 38.9814 & 0.0001 & 0.0003 & 0.0016 \\
\hline 690 & 170.4 & 18.9230 & 15.7018 & 38.9819 & 0.0005 & 0.0005 & 0.0012 \\
\hline 690 & 170.45 & 18.9078 & 15.7018 & 38.9716 & 0.0004 & 0.0004 & 0.0013 \\
\hline 690 & 170.69 & 18.9130 & 15.7023 & 38.9741 & 0.0001 & 0.0001 & 0.0003 \\
\hline 690 & 170.75 & 18.8834 & 15.7087 & 39.0254 & 0.0001 & 0.0001 & 0.0002 \\
\hline 690 & 170.85 & 18.8811 & 15.7069 & 39.0122 & 0.0004 & 0.0005 & 0.0011 \\
\hline 690 & 170.95 & 18.9082 & 15.7056 & 38.9936 & 0.0005 & 0.0004 & 0.0008 \\
\hline 690 & 171.05 & 18.9046 & 15.7092 & 39.0373 & 0.0002 & 0.0002 & 0.0004 \\
\hline 690 & 171.25 & 18.8942 & 15.7033 & 38.9808 & 0.0001 & 0.0004 & 0.0009 \\
\hline 690 & 171.43 & 18.8855 & 15.7127 & 39.0517 & 0.0001 & 0.0003 & 0.0012 \\
\hline 690 & 171.64 & 18.8930 & 15.7119 & 39.0642 & 0.0001 & 0.0001 & 0.0001 \\
\hline 549 & 336.68 & 18.7167 & 15.6372 & 38.6847 & 0.0010 & 0.0011 & 0.0128 \\
\hline 549 & 336.98 & 18.7132 & 15.6384 & 38.6927 & 0.0007 & 0.0008 & 0.0120 \\
\hline 549 & 337.29 & 18.7139 & 15.6395 & 38.6928 & 0.0005 & 0.0004 & 0.0088 \\
\hline 549 & 337.47 & 18.7067 & 15.6388 & 38.6832 & 0.0038 & 0.0001 & 0.0085 \\
\hline 549 & 337.85 & 18.7048 & 15.6385 & 38.6843 & 0.0009 & 0.0006 & 0.0085 \\
\hline 549 & 338.17 & 18.6933 & 15.6404 & 38.6900 & 0.0001 & 0.0002 & 0.0094 \\
\hline 549 & 338.47 & 18.6965 & 15.6411 & 38.6972 & 0.0011 & 0.0011 & 0.0102 \\
\hline 549 & 338.73 & 18.6926 & 15.6431 & 38.7054 & 0.0008 & 0.0005 & 0.0095 \\
\hline 549 & 338.96 & 18.7006 & 15.6414 & 38.6852 & 0.0004 & 0.0005 & 0.0094 \\
\hline 549 & 339.33 & 18.7046 & 15.6388 & 38.6744 & 0.0012 & 0.0011 & 0.0093 \\
\hline 549 & 339.66 & 18.7057 & 15.6388 & 38.6766 & 0.0002 & 0.0002 & 0.0072 \\
\hline 549 & 339.97 & 18.7102 & 15.6385 & 38.6815 & 0.0002 & 0.0001 & 0.0080 \\
\hline
\end{tabular}

Table 3.3 Pb isotope compositions of ODP Site 690 and DSDP Site 549 bulk sediments, agecorrected to the PETM (56 Ma). Errors are defined by a single standard deviation on the measurement. 


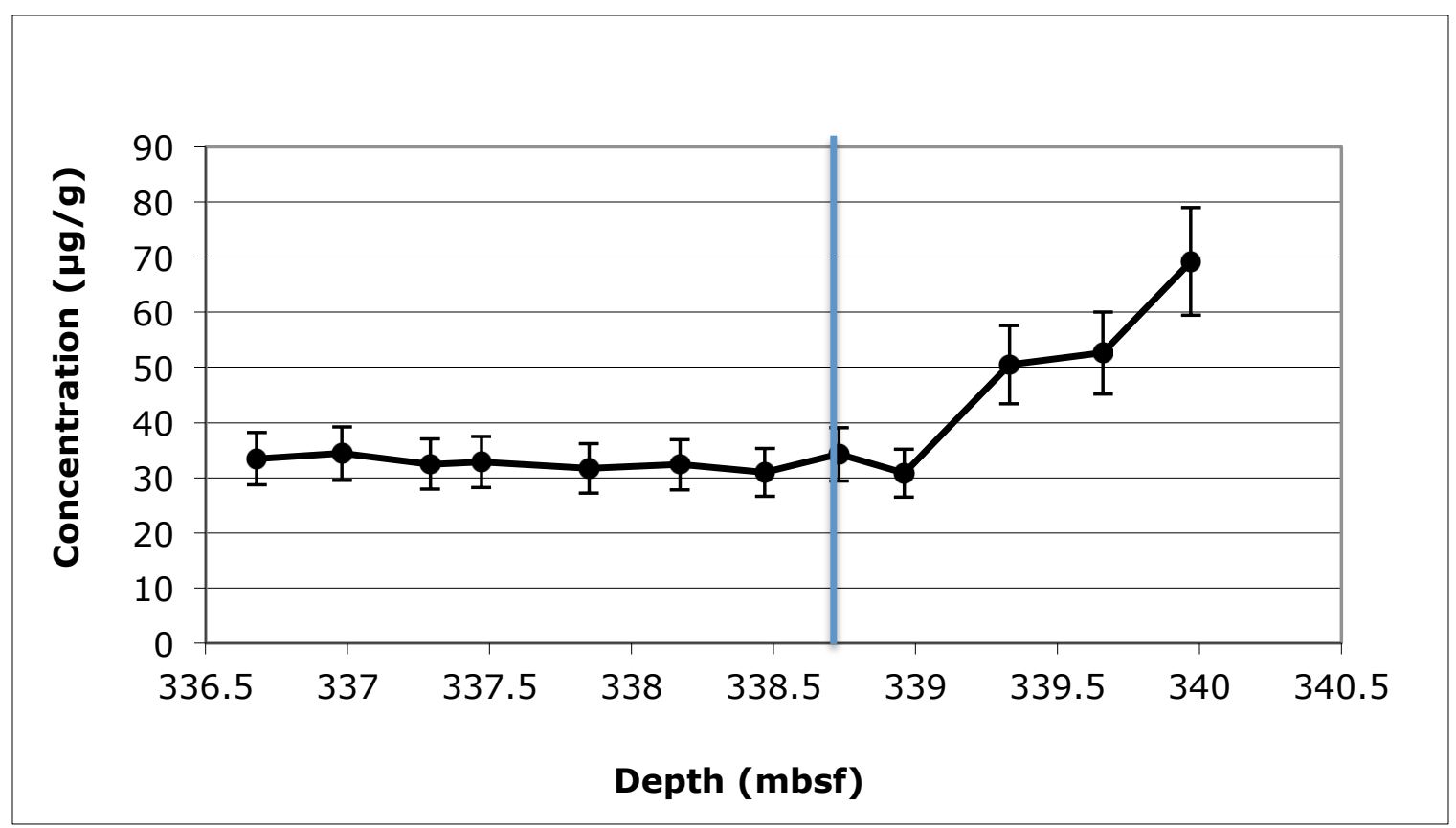

Figure 3.1 Cobalt concentrations normalized to $\mathrm{TiO}_{2}$ for sediments from DSDP Site 549. Cobalt displays significant enrichment at the three deepest depths. This phenomenon is common to many trace elements, and therefore may represent a depletion in $\mathrm{TiO}_{2}$ rather than an enrichment in Co. However, a significant enrichment of Co prior to the PETM cannot be ruled out. The vertical blue line represents the location of the peak of the PETM CIE. 


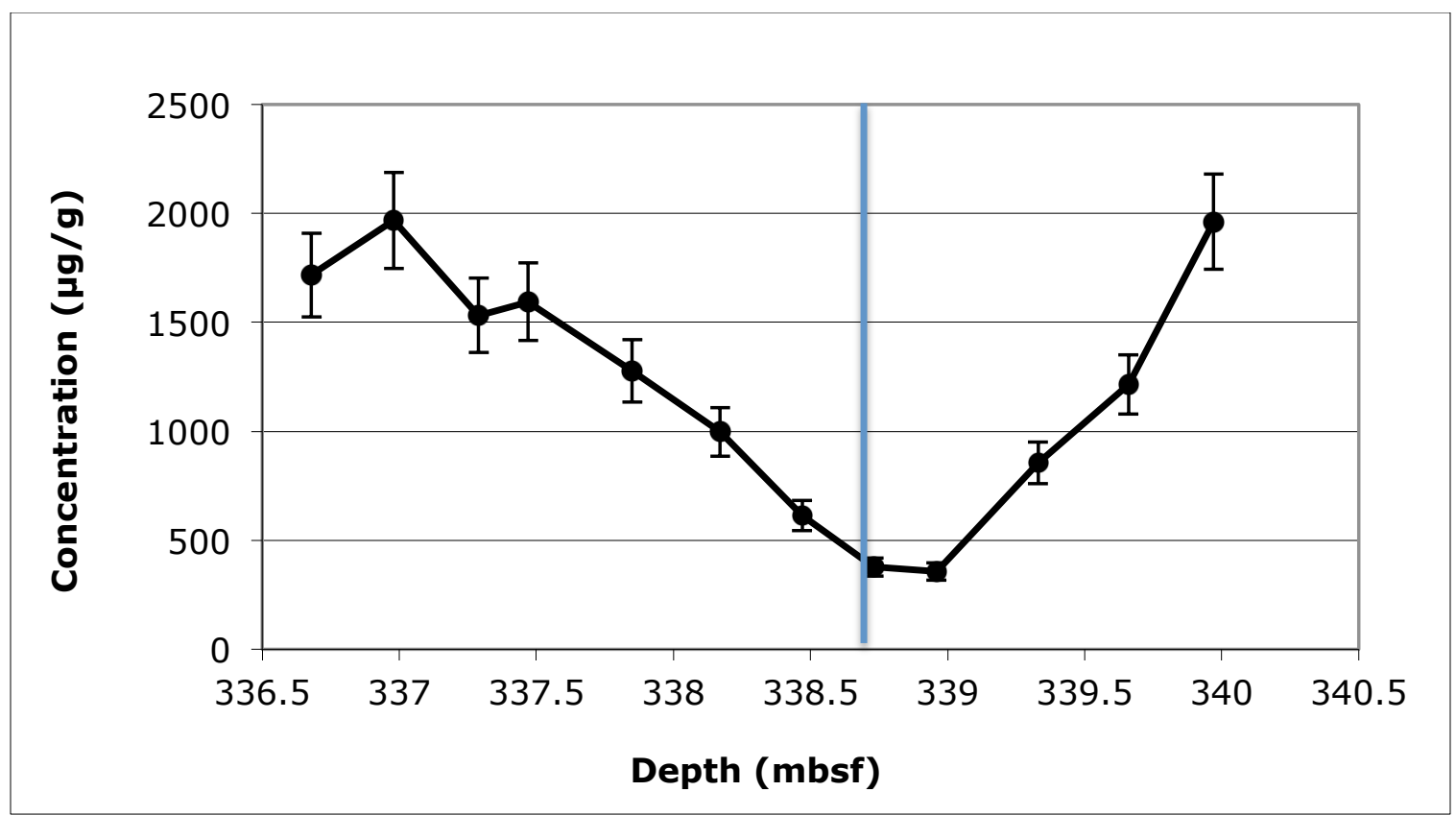

Figure 3.2 Strontium concentrations normalized to $\mathrm{TiO}_{2}$ for sediments from DSDP Site 549 . Strontium shows significant depletion during the PETM. The depletion peaks at 338.96 mbsf, prior to the maximum CIE at 338.73 mbsf. The vertical blue line represents the location of the peak of the PETM CIE. 


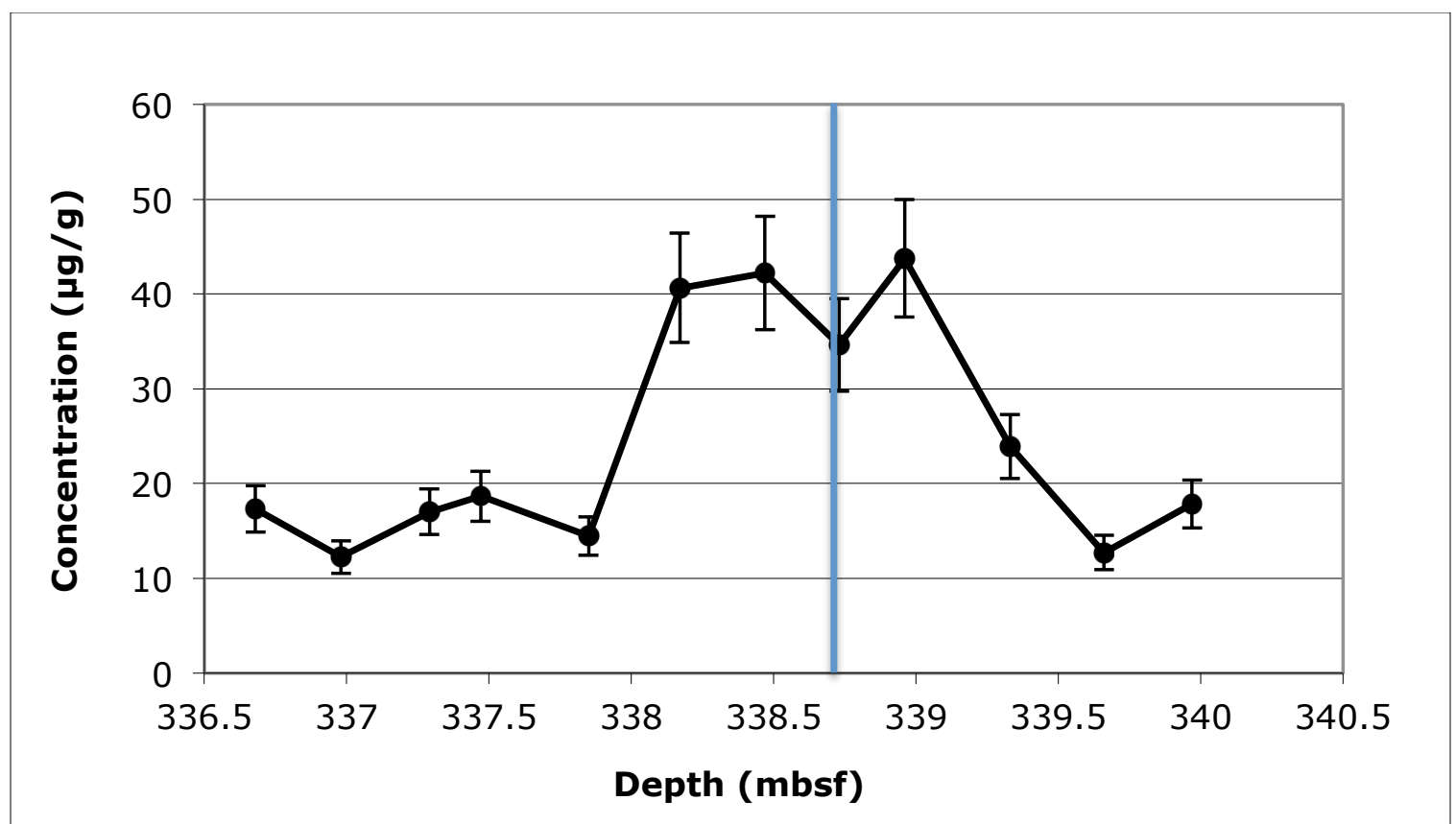

Figure 3.3 Arsenic concentrations normalized to $\mathrm{TiO}_{2}$ for sediments from DSDP Site 549 . Arsenic displays significant enrichment across the PETM. The enrichment peaks at $338.96 \mathrm{mbsf}$, prior to the maximum CIE at 338.73 mbsf. The vertical blue line represents the location of the peak of the PETM CIE. 


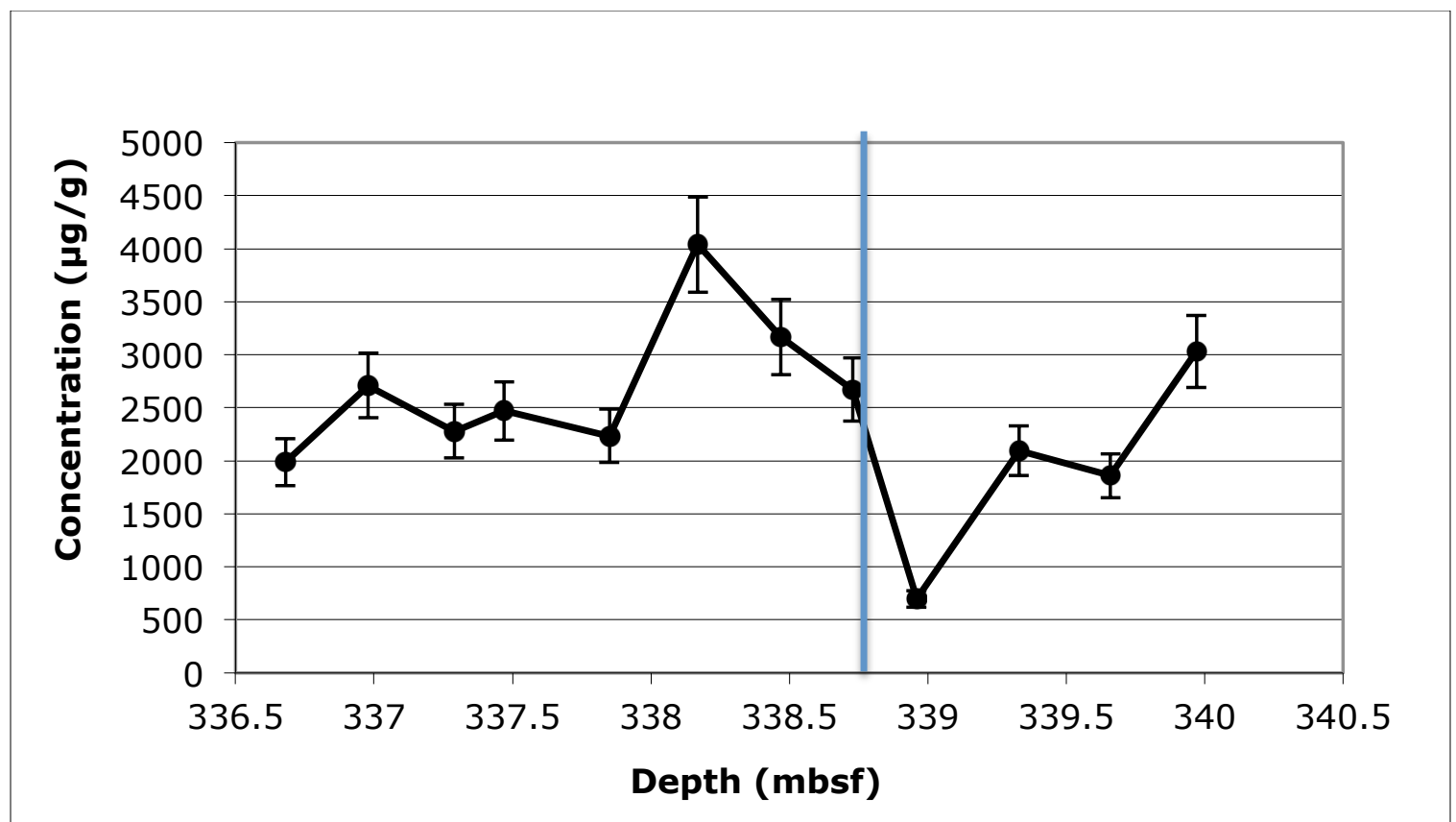

Figure 3.4 Barium concentrations normalized to $\mathrm{TiO}_{2}$ for sediments from DSDP Site 549 .

Concentrations are highly variable, and are poorly correlated to the PETM over the sampled depth intervals. The vertical blue line represents the location of the peak of the PETM CIE. 


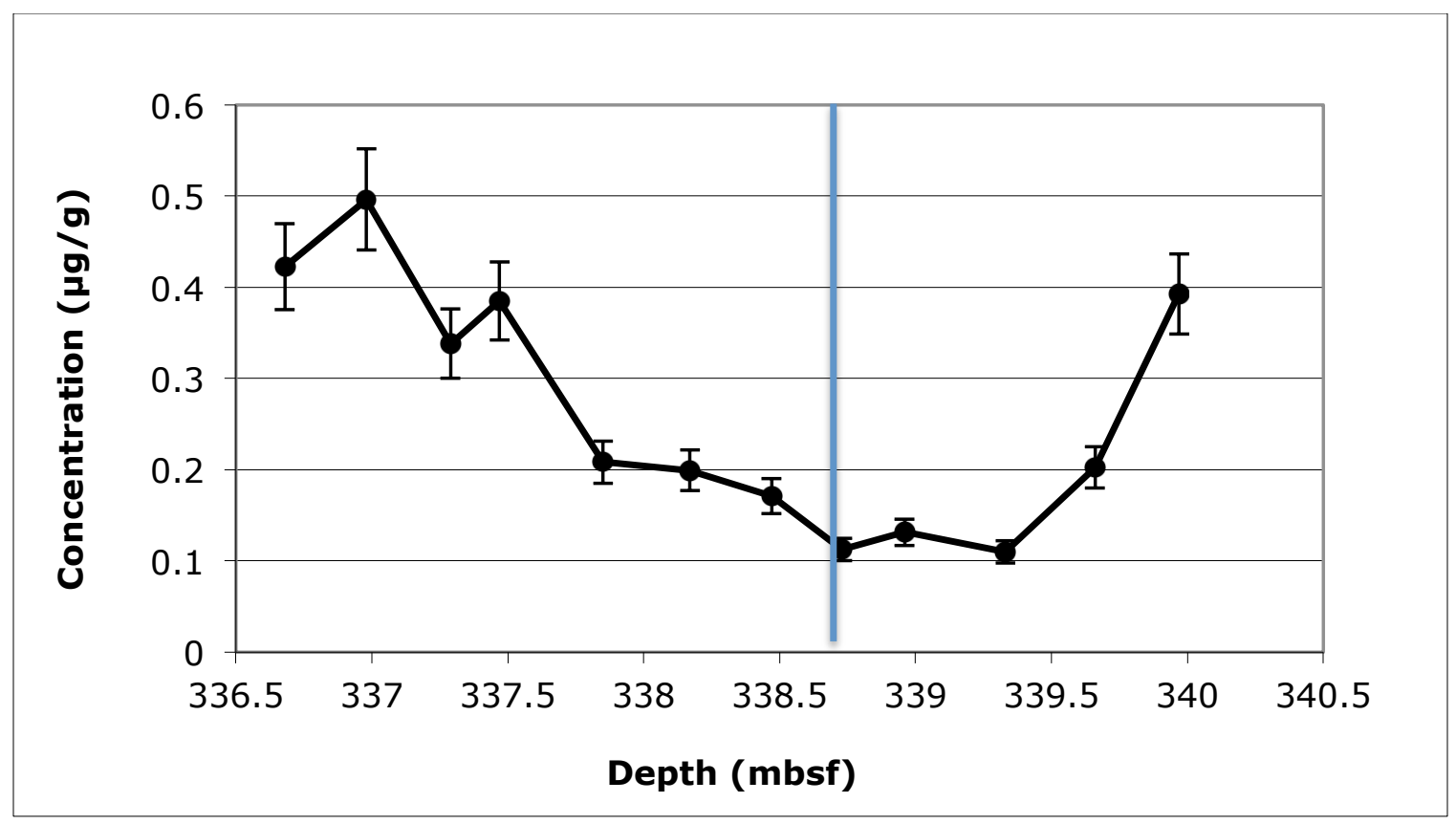

Figure 3.5 $\mathrm{MnO}$ concentrations normalized to $\mathrm{TiO}_{2}$ versus depth for sediments from DSDP Site 549. $\mathrm{MnO}$ is significantly depleted during the PETM. The peak of the depletion (occurring at 339.33 mbsf) occurs deeper than the peaks for As and for the carbon isotope excursion. The correlation between the PETM and $\mathrm{MnO}$ concentrations are less clear, but there does seem to be major changes occurring around the time of the PETM. The vertical blue line represents the location of the peak of the PETM CIE. 


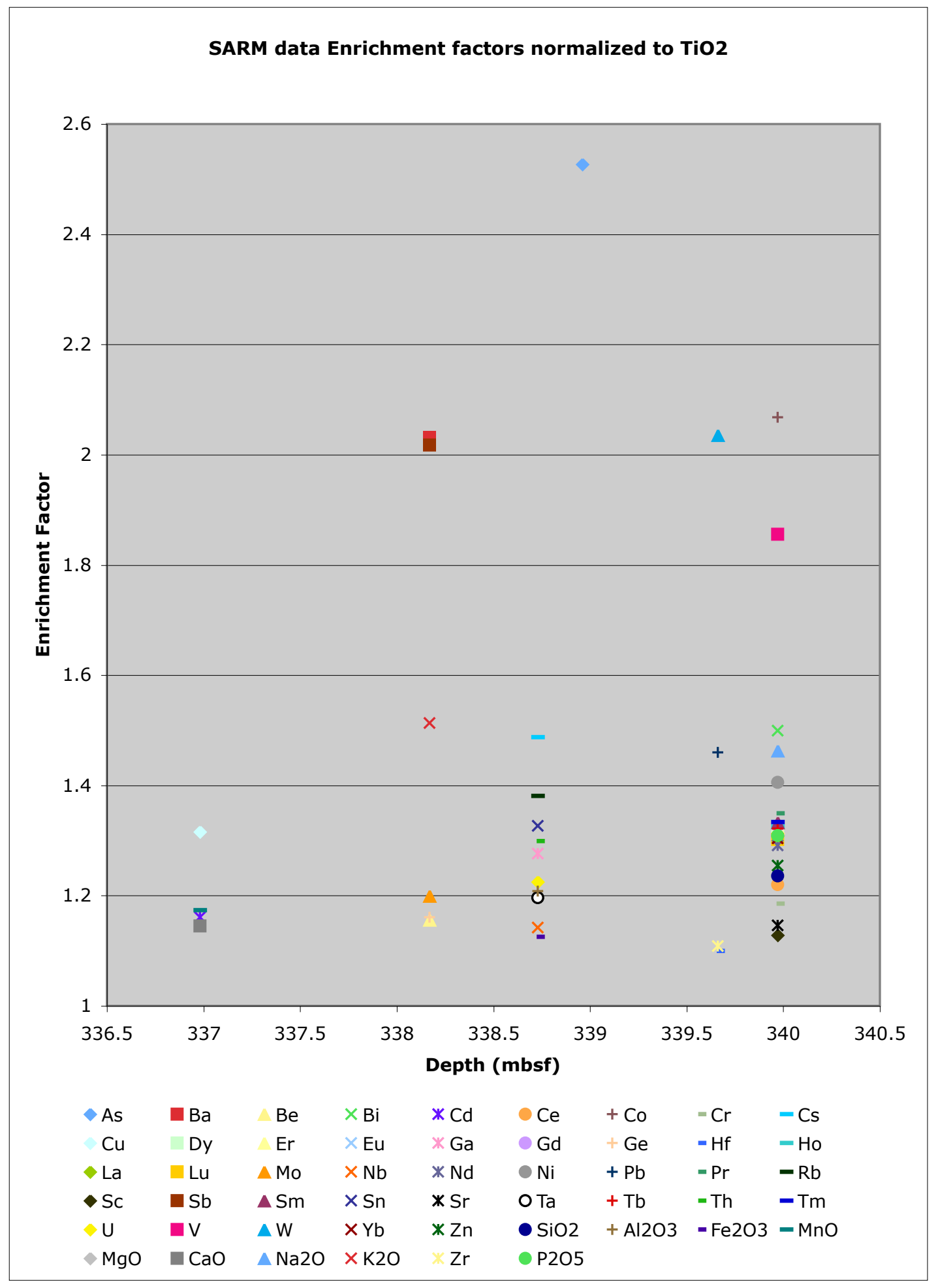

Figure 3.6 Normalized enrichment factors for each element measured by SARM in the core DSDP site 549. The depth along the x-axis is the depth in the core where that particular element 
was the most enriched, with the peak of the PETM CIE located at 338.73 mbsf. The Enrichment Factor is defined as the highest sampled concentration divided by the average post-PETM concentration. 
A
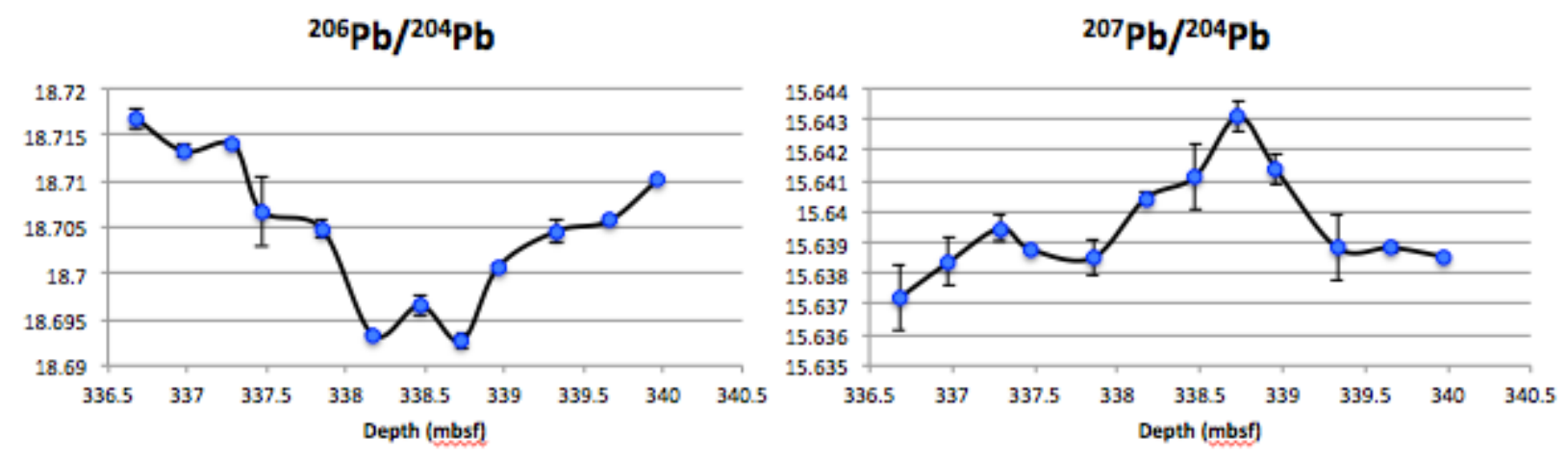

${ }^{208} \mathrm{~Pb} /{ }^{204} \mathrm{~Pb}$
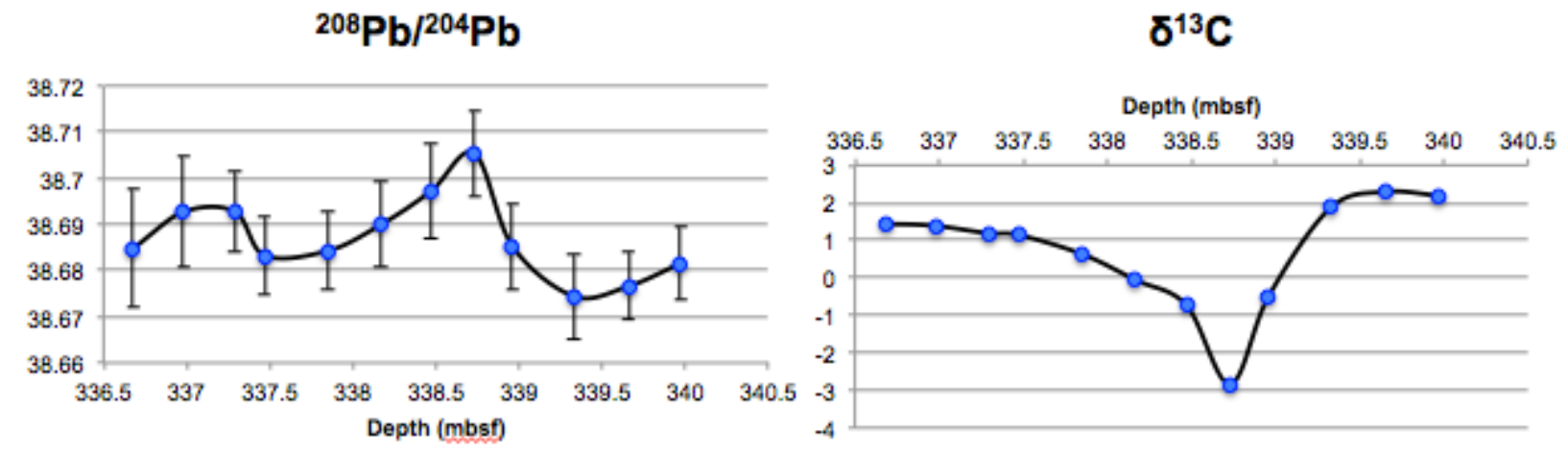

B

${ }^{206} \mathrm{~Pb} /{ }^{204} \mathrm{~Pb}$

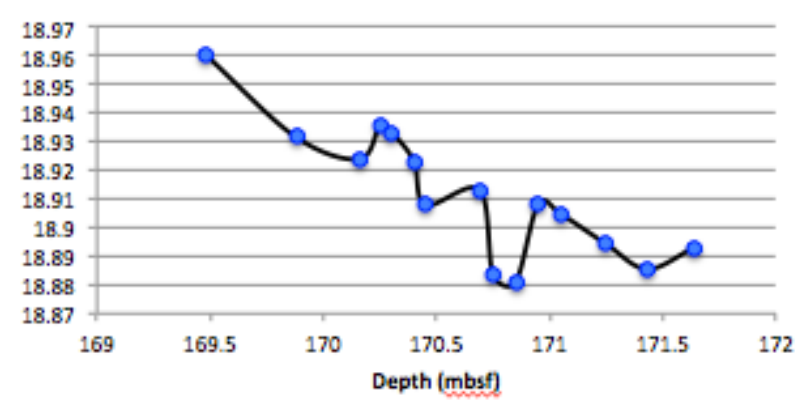

${ }^{208} \mathrm{~Pb} /{ }^{204} \mathrm{~Pb}$

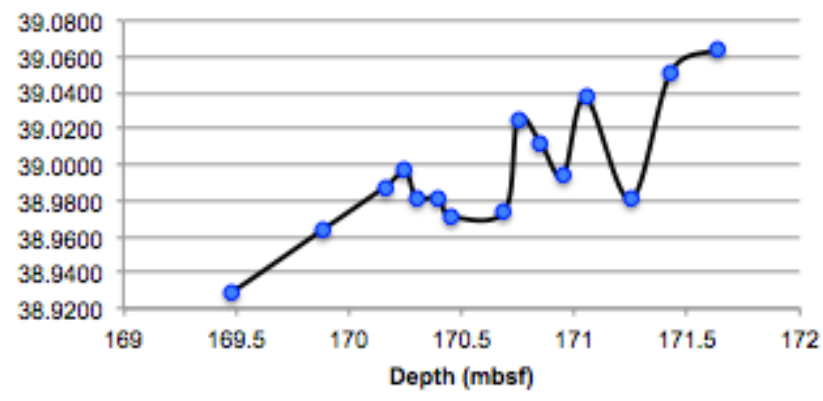

${ }^{207} \mathrm{~Pb} /{ }^{204} \mathrm{~Pb}$

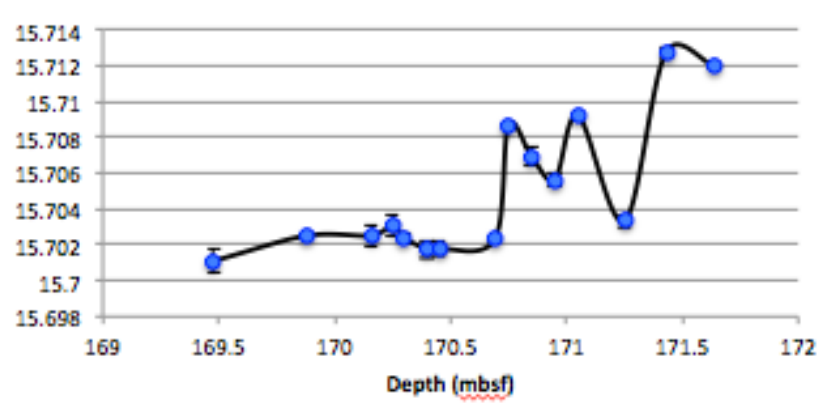

$\delta^{13} \mathrm{C}$

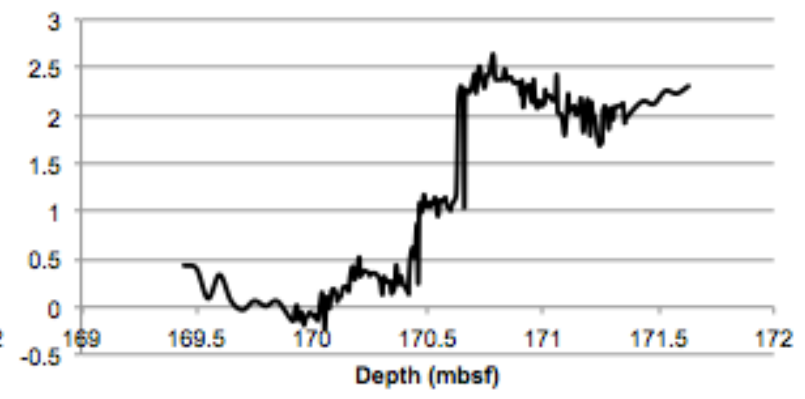


Figure 3.7 Lead isotope ratios corrected to the age of the PETM for bulk sediments from DSDP site 549 (A) and ODP site 690 (B). Also shown are the carbon isotope excursions measured in carbonates for reference. 



Figure 3.8 Lead isotope ratios in ODP 690 (blue) and DSDP 549 (red) bulk sediments plotted versus age. Only the age range that covered both cores is shown. 


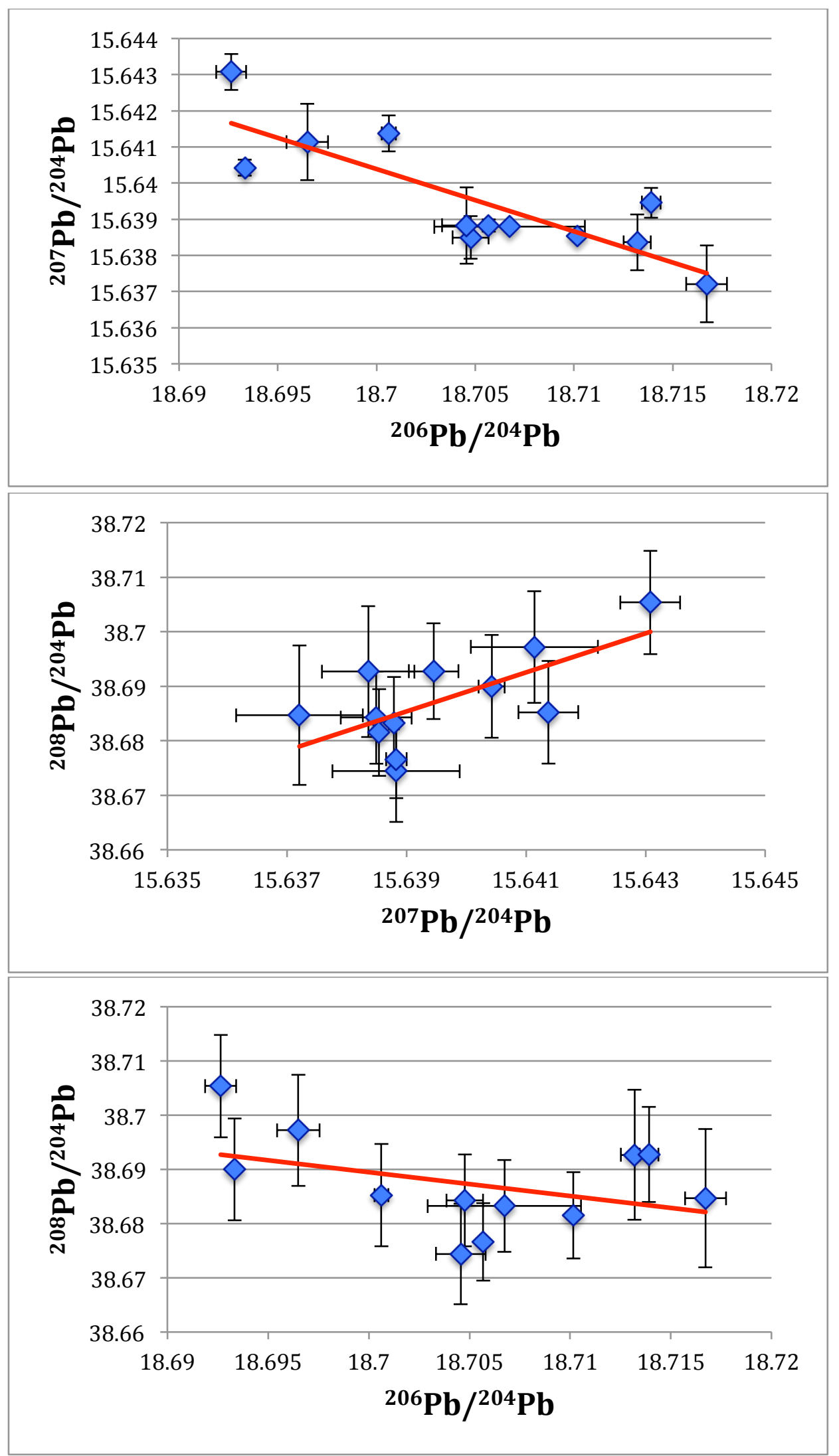


Figure 3.9 $\mathrm{Pb}-\mathrm{Pb}$ diagrams with linear regressions, potentially indicating two-component mixing between two lead sources in bulk sediments from DSDP site 549. 


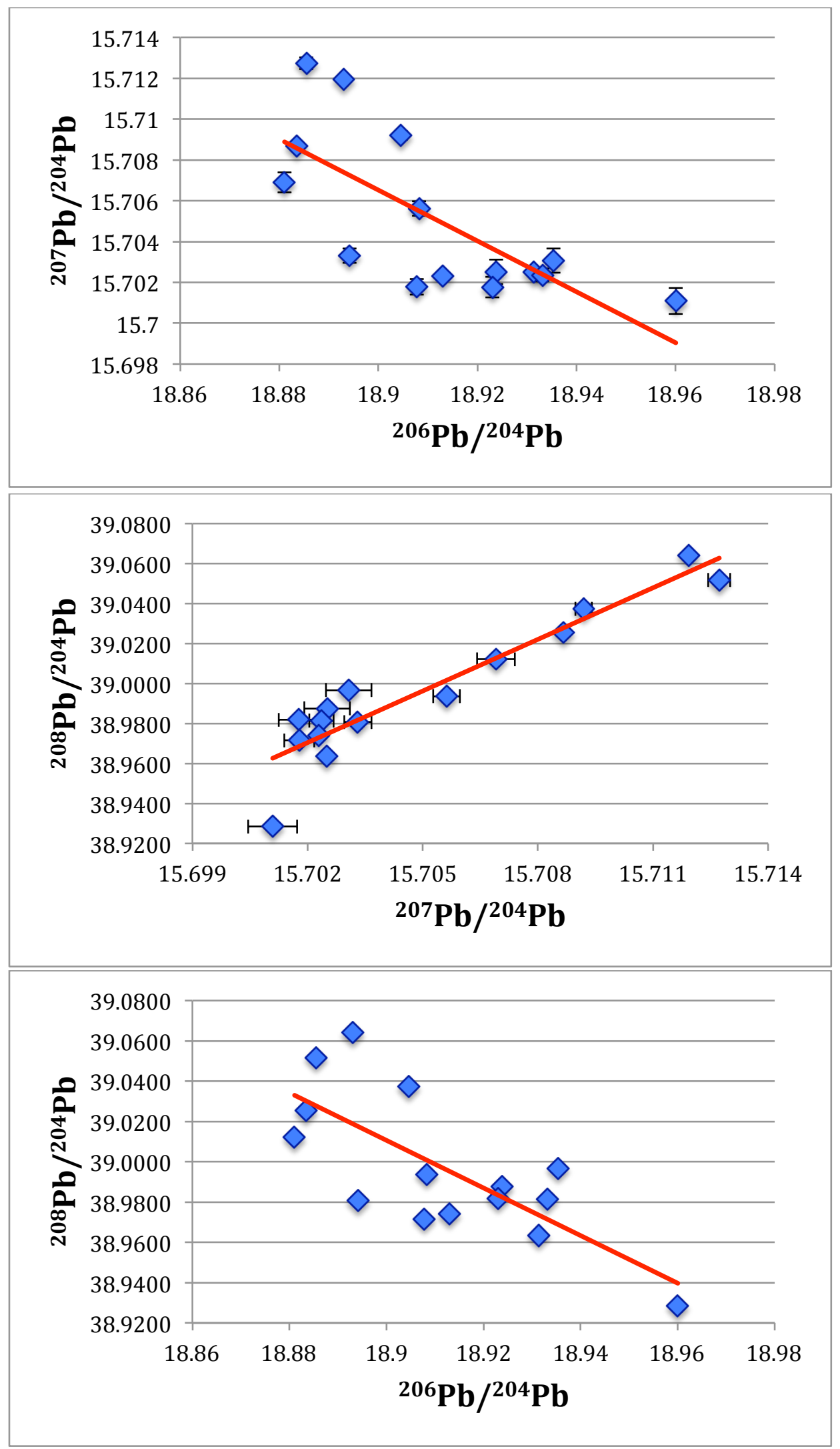


Figure $3.10 \mathrm{~Pb}-\mathrm{Pb}$ diagrams with linear regressions, potentially indicating two-component mixing between two lead sources in bulk sediments from ODP site 690 . 


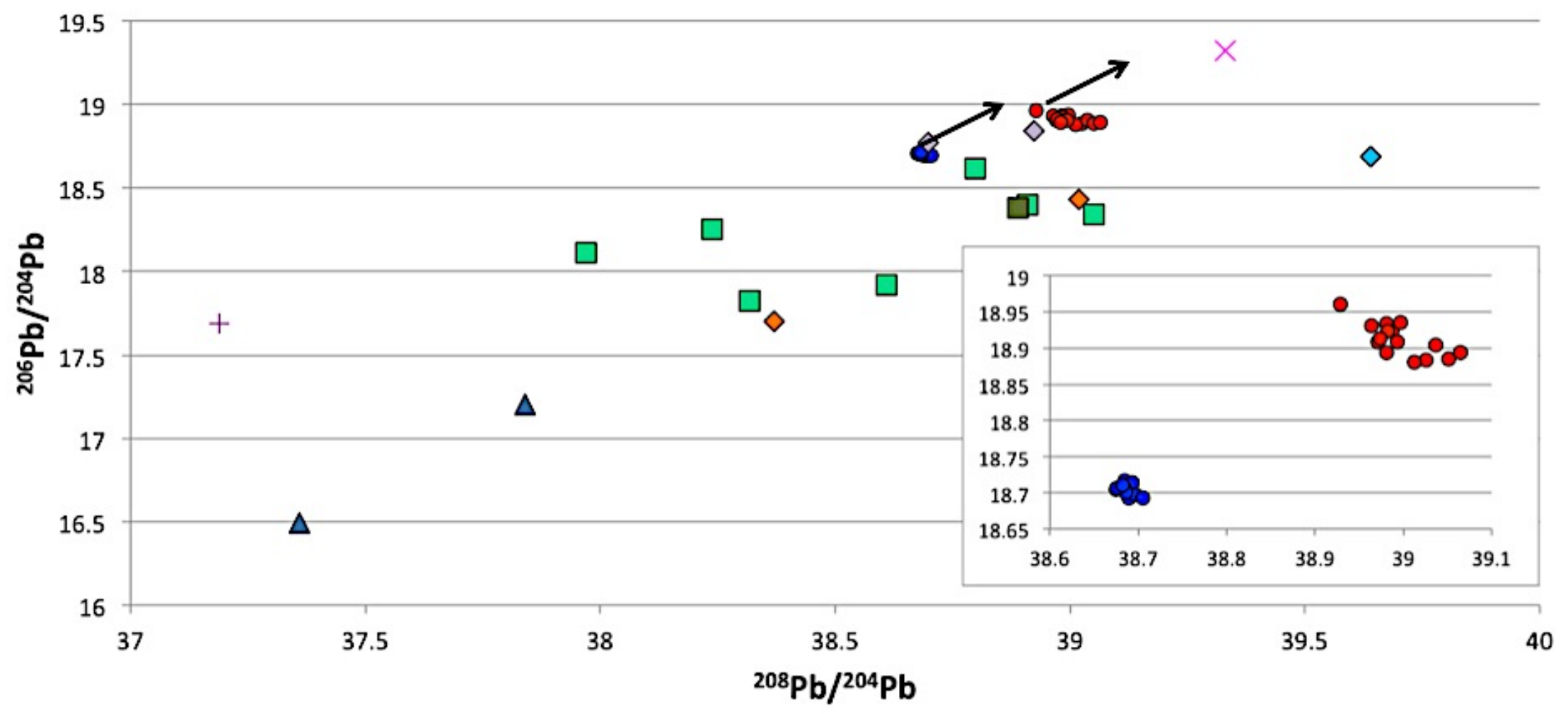

- DSDP 549

OODP 690

$\diamond$ Average CC (Galer and Goldstein, 1996) $\square$ Bulk earth (Allegre et al., 1996) $\diamond$ Average CC (Allegre et al., 1996) $\quad$ A Average CC (Paul et al., 2003)

XUpper CC (Aserom and Jacobson, 1992)
口Bulk earth (Galer and Goldstein, 1996)

+ Depleted mantle (Allegre et al., 1996)

$\Delta$ Lower CC (Paul et al., 2003)

Figure 3.11 Lead isotope compositions of the DSDP and ODP sediment cores (blue and red circles), as well as the bulk silicate earth (squares), average continental crust (diamonds), lower continental crust (triangles), depleted mantle (+), and upper continental crust 
(x). Black arrows indicate the expected trajectory due to input of lead sourced from organic-rich sediments. The inset shows an enlarged version of the change in the isotope ratios observed in the DSDP and ODP bulk sediments. 


\subsection{References}

Allegre, C.J., Dupre, B., Negrel, P., Gaillardet, J., 1996. Sr-Nd-Pb isotope systematics in Amazon and Congo River systems: Constraints about erosion processes. Chemical Geology 131, 93-112.

Aubry, M.-P., 1998. Stratigraphic (dis)continuity and temporal resolution of geological events in the upper Paleocene-lower Eocene deep sea record. In: Late Paleocene-Early Eocene Climatic and biotic events in the marine and terrestrial records. Aubry, M.-P. et al., Eds. Columbia University Press, New York, pp. 37-66.

Asmerom, Y., Jacobsen, S.B., 1993. The Pb isotopic evolution of the Earth: inferences from river water suspended loads. Earth and Planetary Science Letters 115, 245-256.

Barker, P.E, Kennett, J.P., et al., 1988. Leg 113. Proceedings of ODP, Initial Reports, 113: College Station, TX (Ocean Drilling Program). DOI: 10.2973/odp.proc.ir.113.1988

Chow, T.J., Patterson, C.C., 1962. The occurrence and significance of lead isotopes in pelagic sediments. Geochimica et Cosmochimica Acta 17, 21-31.

Craig, H., Krishnaswami, S., Somayajulu, B.L.K., 1973. ${ }^{226} \mathrm{~Pb}-{ }^{226} \mathrm{Ra}$ : radioactive disequilibrium in the deep sea. Earth and Planetary Science Letters 17, 295-305.

Farley, K.A., Eltgroth, S.F., 2003. An alternative age model for the Paleocene-Eocene thermal maximum using extraterrestrial He-3. Earth and Planetary Science Letters 208, 135-148.

Galer, S.J.G., Goldstein, S.L.,1996. Influence of accretion on lead in the Earth. In: Earth Processes: Reading the Isotopic Code. Basu, A., Hart, S. (Eds.), AGU, Washington D.C. 75-98.

Gibbs, S.J., Stoll, H.M., Bown, P.R., Bralower, T.J., 2010. Ocean acidification and surface water carbonate production across the Paleocene-Eocene thermal maximum. Earth and Planetary Science Letters 295, 583-592.

Hart, S.R., Ball, L., 2004. Isotopic homogeneity of the SRM981 Pb isotopic standard. WHOI Plasma Facility Open File Report 12, June, 2004.

Jiang, S., Wise, S.W.J.R., 2009. Distinguishing the influence of diagenesis on the Paleoecological reconstruction of nannoplankton across the Paleocene/Eocene Thermal Maximum: An example from the Kerguelen Plateau, Southern Indian Ocean. Marine Micropaleontology 72, 49-59.

Kawahata, H., Ishizuka, T., 2000. Amino acids in interstitial waters from ODP Sites 689 and 690 on the Maud Rise, Antarctic Ocean. Geochemical Journal 34(4), 247-261.

Kelly, D.C., Nielsen, T., McCarren, H., Zachos, J.C., Röhl, U., 2010. Spatiotemporal patterns of carbonate sedimentation in the South Atlantic: implications for carbon cycling during the 
Paleocene-Eocene Thermal Maximum. Palaeogeography, Palaeoclimatology, Palaeoecology 293, 30-40.

Kennett, J.P., Stott, L.D., 1991. Abrupt deep-sea warming, palaeoceanographic changes and benthic extinctions at the end of the Palaeocene. Nature 353, 225-229.

McLennan, S.M., 2001. Relationships between the trace element composition of sedimentary rocks and upper continental crust. Geochemistry, Geophysics, Geosystems 2, DOI: 10.1029/2000GC00109.

Paul, D., White, W.M., Turcotte, D.L., 2003. Constraints on the ${ }^{232} \mathrm{Th} /{ }^{238} \mathrm{U}$ ratio ( $\kappa$ ) of the continental crust. Geochemistry, Geophysics. Geosystems 4, DOI: 10.1029/2002GC000497.

Peterson, M.D., 1983. The use of the "Immobile" elements $\mathrm{Zr}$ and $\mathrm{Ti}$ in lithogeochemical exploration for massive sulphide deposits in the Precambrian Pecos Greenstone Belt of northern New Mexico. Journal of Geochemical Exploration 19, 615-617.

Raffi, I., Backman, J., Zachos, J.C., Sluijs, A., 2009. The response of calcareous nannofossil assemblages to the Paleocene Eocene Thermal Maximum at the Walvis Ridge in the South Atlantic. Marine Micropaleontology 70, 201-212.

Ravizza G., Norris, R.N., Blusztajn, J., Aubry, M.-P., 2001. An osmium isotope excursion associated with the late Paleocene thermal maximum: Evidence of intensified chemical weathering. Paleoceanography 16, 155-163.

Robinson, N., Ravizza, G., Coccioni, R., Peucker-Ehrenbrink, B., Norris, R., 2009. A highresolution marine ${ }^{187} \mathrm{Os} /{ }^{188}$ Os record for the late Maastrichtian: Distinguishing the chemical fingerprints of Deccan volcanism and the KP impact event. Earth and Planetary Science Letters $281,159-168$

Röhl, U., Bralower, T.J., Norris, G., Wefer, G., 2000. A new chronology for the late Paleocene thermal maximum and its environmental implications. Geology 28, 927-930.

Röhl, U., Westerhold, T., Bralower, T.J., Zachos, J.C., 2007. On the duration of the PaleoceneEocene Thermal Maximum (PETM). Geochemistry, Geophysics, Geosystems 8, Q12002.

Smedley ,P.L., Kinniburgh, D.G., Huq, I., Luo, Z., Nicolli, H.B., 2001. International perspective on naturally occurring arsenic problems in groundwater. In: Arsenic Exposure and Health Effects IV. Chappell, W.R., Abernathy, C.O., Calderon, R.L. Eds. Elsevier, Amsterdam, pp. 925.

Smedley, P.L., Kinniburgh, D.G., 2002. A review of the source, behavior and distribution of arsenic in natural waters. Applied Geochemistry 17, 517-568. 
Stoll, H.M., Bains, S., 2003. Coccolith Sr/Ca records of productivity during the PaleoceneEocene thermal maximum from the Weddell Sea. Paleoceanography 18, doi:10.1029/2002PA000875.

Stott, L.D., Sinha, A., Thiry, M., Aubry, M.-P., Berggren, W.A., 1996. Global $\delta^{13}$ C changes across the Paleocene-Eocene boundary: Criteria for terrestrial-marine correlations in correlation of the Early Paleogene in Northwest Europe. Geological Society Special Publications 101, 381399.

Svensen, H, Planke, S., Melthe-Sørenssen, A., Jamtveit, B., Myklebust, R., Rasmussen Eidem, T., Rey, S.S., 2004. Release of methane from a volcanic basin as a mechanism for initial Eocene global warming. Nature 429, 542-545.

Vonhof, H.B., Jagt, J.W.M., Immenhauser, A., Smit, J., Van den Berg, Y.W., Saher, M., Keutgen, N., Reijmer, J.J.G., 2011. Belemnite-based strontium, carbon and oxygen isotope statigraphy of the type area of the Maastrichtian Stage. Netherlands Journal of Geosciences 90, 259-270. 


\section{CHAPTER 4.}

\section{Geochemical effects of contact metamorphism on the organic-rich Pierre Shale in the Raton Basin, New Mexico}

\subsection{Abstract}

One hypothesis for the Paleocene Eocene Thermal Maximum (PETM) links the evolution of climate and life to deep-Earth processes, specifically magmatism associated with the North Atlantic Magmatic Province. In this hypothesis, rifting of the North Atlantic basin triggers intrusions of large sill complexes into organic-rich sediments, releasing large quantities of stored carbon into the ocean-atmosphere system. Organic-rich sediments, which are enriched in redox sensitive elements such as rhenium and uranium, develop isotope signatures of osmium and lead that are distinct from average upper continental crust, thus providing a fingerprint of its origin. In this chapter the effect of thermal alteration of organic-rich sediments on the concentrations and isotopic compositions of osmium, lead, and carbon is tested in a terrestrial environment. While organic carbon is almost quantitatively removed, no evidence is found of mobilization of either $\mathrm{Os}$ or $\mathrm{Pb}$, indicating neither appears to be good a proxy for mobilization of organic carbon by thermal alteration of organic-rich sediments in a terrestrial setting.

\subsection{Introduction}

Key to evaluating whether submarine organic-rich sediments are likely sources of organic carbon released at the PETM (Svensen et al., 2004) is quantifying the relationship between the losses of organic carbon $(\mathrm{OC})$, osmium $(\mathrm{Os})$ and lead $(\mathrm{Pb})$, as well as the impact on their respective isotopic systems in the metamorphic aureole of a magmatic intrusion. The isotopic compositions of the $\mathrm{C}$ and Os released by this process are not well known and need to be 
determined because they affect the mass of $\mathrm{C}$ necessary to explain the $\mathrm{C}$ isotope excursion at the PETM. In this chapter, I examine a potential terrestrial analog to submarine magmatic intrusions associated with the North Atlantic Magmatic Province (NAMP) in order to constrain the behavior of these elements during contact-metamorphic alteration of organic-rich sediments.

The Raton Basin was selected as a potential terrestrial analog to investigate sedimentmagma interactions beneath the seafloor. The basin is located in northern New Mexico and southern Colorado, and is composed primarily of sedimentary sequences of dark silty shale deposited at the end of the Cretaceous during the regression of the Western Interior Seaway (Cooper et al., 2007; Flores and Bader, 1999; Pillmore et al., 1984). Periods of highly stratified waters led to bottom water anoxia and the development of organic-rich shales, including the Pierre Shale (Dean and Arthur, 1989). These sediments were then uplifted during the Laramide Orogeny in the late Cretaceous to early Tertiary (Sharp, 1948).

The Raton basin was also subject to extrusive and intrusive igneous activity during the late Oligocene and early Miocene ( $20-25 \mathrm{Ma})$, likely associated with the Rio Grande Rift (Flores and Bader, 1999; Miggins, 2002). The lavas consist primarily of alkali olivine basalts, although the composition ranges from hauyne-olivine-nephelinite to tridymite-bearing hornblende-dacite (Stormer, 1972). The dikes and sills in the basin are basaltic and lamprophyric, and generally have an East-West orientation (Cooper et al., 2007). These intrusions occurred between 19.9 and 35 Ma (Lee, 2005; Penn, 1995; Miggins, 2002). Cooper (2006) and Cooper et al. (2007) report loss of volatiles from Raton Basin coal seams that have been metamorphosed by igneous intrusions (Figure 4.1). These authors demonstrate significant depletion of total organic carbon (TOC) and an increase in the $\delta^{13} \mathrm{C}$ of the remaining organic carbon, indicative of significant loss of isotopically light organic carbon (which the authors 
suggest is most likely as a volatile phase such as $\mathrm{CO}_{2}$ and $\mathrm{CH}_{4}$ ) from such sediments.

\subsection{Methods}

\subsubsection{Field sampling}

Field samples were taken from the Tinaja outcrop located in the Raton Basin in northern New Mexico, roughly $27 \mathrm{~km}$ south of the city of Raton in the Raton Clayton volcanic field (Figure 4.2). The outcrop, a road cut, is located at $36.665^{\circ}$ latitude and $-104.495^{\circ}$ longitude on the western side of Interstate 25, just north of exit 435 (Figure 4.3). The Tinaja outcrop consists of a ridge formed by horizontal bedding planes of the Sharon Springs member of the Cretaceous Pierre Shale (Scott, 1986) cross-cut by multiple Oligocene/Miocene mafic intrusions that comprise the composite Eagle Rock dike (Figure 4.4). The intrusion of this basanitic dike has been dated by the K-Ar method at 24.16 \pm 1.01 Myr (Scott et al., 1990), and major element and normative mineral compositions are reported in table 17 of Scott et al. (1990). The edges of the ridge are flanked by scree from the relatively soft Pierre Shale. This site was selected due to the ease of access and the cross-cutting relationship between the dike and the bedding planes, allowing sampling along a bedding plane at varying distances from the dike. Sampling along a bedding plane is particularly important to ensure that observed chemical differences are the result of metamorphic alterations and not changes in the chemical composition of the sediments at the time of deposition. The Eagle Rock dike is $8.8 \mathrm{~m}$ wide. Next to the dike the Pierre Shale is metamorphosed to hornfels. Farther from the intrusion the Pierre Shale is less metamorphosed and is very brittle and broken up, but bedding planes are still clearly visible in several places.

Samples were taken midday on August 26, 2012 along a single bedding plane at various distances from the point of contact between the intrusion and the shale to a distance 9 meters away from the contact. A total of seventeen samples were collected by digging into the outcrop 
with a hammer, with a higher sampling density closer to the dike. Two samples of the Eagle Rock dike were also collected, one from the dike next to the shale profile, another from high on the ridge.

\subsubsection{Sample processing}

Samples that were large enough were cut with a rock saw to remove visible alteration from the exterior of the rock. Samples were then sandblasted to remove contamination from the rock saw or for samples not large enough for cutting with the saw from alteration. The samples were then placed between two pieces of clean plastic bags and crushed to smaller pieces, followed by another iteration of sandblasting to clean samples with alteration planes. The cleanest pieces were then picked out and crushed further using a jaw crusher with WC (tungstencarbide) plates. The jaw crusher was wiped clean and residual particles from the previous sample were removed using pressurized air. After crushing, any pieces with visible alteration were picked out. The remaining pieces were ground into a fine powder in a SPEX Shatterbox 8505 with an alumina ceramic grinding barrel for five minutes. The barrel was cleaned after each use by rinsing it five times with tap water and three times with de-ionized (DI) water. Between samples the barrel was cleaned by grinding the equivalent of a $25 \mathrm{~mL}$ volume of clean quartz sand for 5 minutes. The recovered sample powder was transferred to clean plastic vials for storage.

\subsubsection{Organic carbon analyses}

Total organic carbon (TOC) and $\delta^{13} \mathrm{C}$ of the bulk sediment were measured in WHOI's Organic Geochemistry Facility (Whiteside et al., 2011). Samples containing approximately 100 $\mu \mathrm{g}$ organic carbon were weighed into methanol-rinsed silver boats $(4 \times 6 \mathrm{~mm}$, Costech). A 96- 
well glass plate holding these samples was then placed in a vacuum desiccator that also contained an open dish with $\sim 50 \mathrm{ml}$ concentrated hydrochloric acid ( $\mathrm{HCl})$. An inverted crystallization dish was placed over the samples to protect them from water that could condense and drop down from the desiccator top during heating. The desiccator was closed and evacuated with an air-driven aspirator to about 0.5 atm and was placed in an oven between 60 and $65^{\circ} \mathrm{C}$ for 60 to 72 hours. Every 10-12 hours the seal on the desiccator was greased with a small amount of Apiezon L. The samples were then transferred to another vacuum desiccator charged with indicating silica gel (Fisher S162-500) overnight, then evacuated again and dried for about 24 hours prior to use.

Immediately prior to analysis, the sample boats were put into methanol-rinsed tin boats (4 x $6 \mathrm{~mm}$, Costech) and pelletized with forceps. These samples were loaded into the carousel of a Costech Zero Blank autosampler, along with standards and blanks. The standards used are USGS-40 Glutamic Acid, IAEA-N1 Ammonium Sulfate, and a lab standard of Glycine that has been well characterized for $\delta^{13} \mathrm{C}$ and $\delta^{15} \mathrm{~N}$. Samples are then combusted on a Carlo Erba / Fisons 1108 Flash Combustion Elemental Analyzer, with the resulting $\mathrm{N}_{2}$ and $\mathrm{CO}_{2}$ gases being analyzed on a Finnigan-MAT DeltaPlus isotope ratio mass spectrometer. Raw data (area and isotope ratios) are collected using the Isodat software package, then exported to an Excel spreadsheet for quantitation, blank correction and statistical treatments, following Whiteside et al. (2011).

\subsubsection{Major and trace element analyses}

Major (X-ray fluorescence; XRF) and trace element analyses (XRF and Inductively Coupled Plasma Mass Spectrometer; ICPMS) were carried out in the Service d'Analyse des Roches et des Minéraux (SARM) laboratory at the CNRS laboratory in Nancy, France (see chapter 3). Major elements were analyzed at SARM as oxides, and reported as a percentage (by 
weight) of the total sample. Uncertainties in the measurements vary according to concentrations and are based on repeat analyses of standards.

\subsubsection{Re-Os isotope analysis}

Re-Os isotope analyses were performed on the sediment samples following the procedure outlined in Sen and Peucker-Ehrenbrink (2014). $500 \mathrm{mg}$ of powdered sample was weighed and transferred to a clean High Pressure Asher (HPA-S, Anton Paar) reaction vial (20 ml quartz glass). The samples were spiked with ${ }^{190} \mathrm{Os}$ and ${ }^{185} \mathrm{Re}$ tracers, then $4 \mathrm{ml}$ of inverse Aqua Regia ( $1 \mathrm{ml}$ of PicoTrace clean concentrated $\mathrm{HCl}$ and $3 \mathrm{ml}$ of PicoTrace clean concentrated $\mathrm{HNO}_{3}$ ) were added, and the samples were allowed to react. The vials were sealed with Teflon tape, then a glass cap was placed on top and secured with Teflon tape. The closed vials were transferred to the HPA, pressurized with nitrogen gas to $100 \mathrm{bar}$, and heated at $260^{\circ} \mathrm{C}$ for 45 minutes. The temperature was slowly ramped up to $260^{\circ} \mathrm{C}$ over 45 minutes to avoid violent exothermic reaction. Between uses, sample vials were cleaned by rinsing several times with Milli-Q (Millipore) water, then ultra-sonicated in very dilute hydrofluoric acid, rinsed several times again with Milli-Q water, and finally heated in the HPA with $4 \mathrm{ml}$ of clean inverse Aqua Regia using the same procedure as used for the digestion. After digestion, the HPA was allowed to cool until the temperature in the pressure vessel had dropped below $40^{\circ} \mathrm{C}$, then was slowly vented to prevent loss of sample from the reaction vials. Samples were removed from the HPA and decanted into clean $33 \mathrm{ml}$ Savillex Teflon beakers, capped tightly, and placed on ice.

For Os isotope measurement, samples were diluted with $4 \mathrm{~mL}$ of Milli-Q water and beakers were fitted with caps containing ports on opposite sides for $1 / 8$ inch Teflon tubing. Argon gas was bubbled through the sample and the resulting volatilized $\mathrm{OsO}_{4}$ was transferred through the opposing port, the silicone transfer tubing and finally into the plasma of the 
ThermoElectron NEPTUNE multi-collector ICPMS (MC-ICPMS). The transfer tubing was changed between samples to prevent contamination. Sample argon gas flow rate was slowly increased until a maximum ion beam signal was reached, typically around $1.1 \mathrm{~L} / \mathrm{min}$.

Osmium isotope analysis on the dike samples was performed using isotope dilution ICPMS analyses after nickel sulfide fire assay preconcentration (Ravizza and Pyle, 1997). Five grams of sample were weighed and transferred to a glazed ceramic crucible. Approximately 0.15 $\mathrm{g}$ of a mixed platinum group element (PGE) spike was added and allowed to dry overnight. Ten gram of flux mixture consisting of borax, nickel, and sulfur (in a 30:2:1.2 weight ratio) was added and mixed with sample and spike. The crucible containing this mixture was heated in a furnace at $1020^{\circ} \mathrm{C}$ for 90 minutes, then removed and allowed to cool. The resulting glass was crushed and the NiS bead was removed from the bottom of the crucible. The bead was dissolved in an Erlenmeyer flask in a boiling 1:1 mixture of concentrated reagent-grade concentrated $\mathrm{HCl}$ and Milli-Q water. Following complete dissolution, the solution was allowed to cool and was filtered through a $0.45 \mu \mathrm{m}$ cellulose filter to collect remaining particles containing the PGE. These samples were then sparged on the MC-ICPMS following the same procedure as described above.

Procedural blanks for Os digested in the HPA were consistently overspiked, indicating lower than expected blank values. For the blank corrections, upper limits on the corrections were assumed based on previously analyzed procedural blanks that were based on processing of $1 \mathrm{~g}$ of flux-fusion mixture. These corrections likely overestimate the extent of the blank correction, as the HPA analyses only used mineral acids and no flux-fusion reagents that likely carry the majority of the analytical blank. This approach leads to a blank correction of $\sim 0.5 \mathrm{pg}$ Os, and a maximum blank correction of $0.6 \%$ of total sample Os. Blank corrections for the NiS 
fire-assay were similarly based on previously analyzed procedural blanks for the same fluxfusion mixture, but were corrected to account for the actual amount of flux mixture used. The procedural blanks corrections for the Os-poor dike samples are much higher and account for as much as $19 \%$ of the total sample Os.

Following Os analysis, the residual sediment sample solutions were dried for determination of Re concentrations by isotope dilution. The residual dike sample solutions were not suitable for Re analysis due to high Re blanks from the flux mixture as well as questionable spike-sample equilibration during the NiS fire assay (Savard et al., 2010). Instead, new aliquots of dike samples were dissolved in mineral acids. $500 \mathrm{mg}$ of these samples were weighed into clean $33 \mathrm{ml}$ Savillex Teflon beakers and spiked with ${ }^{185}$ Re. Three ml of PicoTrace concentrated nitric acid and $1 \mathrm{ml}$ of hydrofluoric acid were added and samples were digested at $170^{\circ} \mathrm{C}$ for 24 hours. Samples were then dried slowly at low temperature before $2 \mathrm{ml}$ of $6 \mathrm{~N} \mathrm{HCl}$ was added to the dried residue. Samples were digested overnight at $150^{\circ} \mathrm{C}$ and then dried again. All samples were re-dissolved in $10 \mathrm{ml}$ of $0.5 \mathrm{~N}$ nitric acid and centrifuged at $3000 \mathrm{rpm}$ for 5 minutes. Rhenium was then extracted and purified from the supernatant using the procedure outlined in Morgan et al. (1999). Samples were passed through columns with $1 \mathrm{ml}$ AG 1x8 (100-200 mesh, Bio-Rad) resin, and Re was eluted with $10 \mathrm{ml}$ of $4 \mathrm{~N}$ nitric acid. Rhenium isotope analysis was then performed in the WHOI ICPMS Facility using the single-collector, magnetic sector ICPMS (ThermoElectron Element2). Procedural Re blanks measured were found to be insignificant $(<1 \%)$ compared to the sample concentrations. 


\subsection{Results}

\subsubsection{Organic carbon}

Samples range in TOC content from $0.033 \mathrm{wt} . \%$ to $1.00 \mathrm{wt} . \%$, characterizing them as relatively organic-poor despite their dark appearance. Samples closer to the contact are significantly depleted in TOC compared to those farther from the contact (Figure 4.5). We did not sample far enough away from the contact to detect the plateau in primary TOC concentrations, and TOC concentrations may continue to increase above the $1.00 \mathrm{wt} . \%$ level found $892 \mathrm{~cm}$ from the contact. While significant differences are noted in the $\delta^{13} \mathrm{C}$ data, no apparent trend or correlation with TOC could be determined. Significantly lower TOC values than expected led to relatively large uncertainties in the $\delta^{13} \mathrm{C}$ values. A very slight trend towards more negative isotope values at distances farther from the contact from the contact may exist, indicating that the lost organic carbon may be isotopically lighter than the residual organic carbon. However, the correlation coefficients between the distance from the contact and $\delta^{13} \mathrm{C}$ ( 0.11 for a linear and 0.26 for a logarithmic least squares regression) are very poor and ${ }^{13} \mathrm{C}$ variations do not correlate well with TOC, and the uncertainties are quite high, leading me to conclude that no significant trend is discernable in $\delta^{13} \mathrm{C}$ over the profile.

Total nitrogen concentrations were also measured over the profile and show depletion close to the contact, similar to TOC (Figure 4.6). Nitrogen concentrations exhibit a more gradual trend than TOC, but may also be affected by non-organic nitrogen-containing phases, such as clay minerals.

\subsubsection{Major and trace element analysis}

The raw data were first normalized to the mass lost on ignition in order to correct for variations in moisture that reflect changes in the extent of sample alteration. Concentrations 
were then normalized to $\mathrm{Zr}$ and $\mathrm{TiO}_{2}$, which are both assumed to be immobile (Peterson, 1983) and related to the detrital fraction, an approach suitable to correct for changes in sedimentation rate, the effects of sediment focusing and carbonate dissolution. Normalizing to immobile elements does not change the spatial trends in the data significantly, as the profiles for these elements are invariant with distance from the contact. Therefore, the raw data were used instead to avoid errors introduced by the normalization procedures.

No trends or significant correlations were found between any of the major or trace elements examined and the distance from the contact. Similarly, no significant correlation was found between the TOC depletion and any other element analyzed.

The following discussion focuses on the elements of the U-Th-Pb isotope systems to determine how metamorphic processes affect these particular isotope systems. Neither U nor Th exhibit significant changes in concentrations with distance from the contact (Figure 4.7). Lead concentrations are relatively constant through the section, with the exception of four shales located between $\sim 2.5$ and $\sim 5.5 \mathrm{~m}$ from the contact that show significantly lower $\mathrm{Pb}$ concentrations. These samples were taken from a thick band of lighter-colored shales (Figure 4.4). During processing these samples revealed numerous bedding planes with alteration features indicating more extensive weathering of these samples compared to the rest of the profile. Lead concentrations do not correlate with TOC concentrations.

\subsubsection{Re-Os isotope system}

Osmium shows bimodal distributions in concentrations (Figure 4.8a) and isotope ratios (Figure 4.8b), with an inverse correlation between the two. There is a grouping of data points with high Os concentrations and low ${ }^{187} \mathrm{Os} /{ }^{188} \mathrm{Os}$, henceforth referred to as "Group A", and a

grouping of data points with low Os concentrations and high ${ }^{187} \mathrm{Os} /{ }^{188} \mathrm{Os}$, henceforth referred to 
as "Group B". Osmium isotopes do not correlate with any other geochemical parameter analyzed that would give an indication of the cause of the bimodal distribution. Regardless of the cause of the distribution, each grouping is considered separately to disentangle the metamorphic processes from the process causing the bimodal distribution.

Least squares regressions were performed individually on group A and group B samples against the distance from contact for both the concentration and isotope data using both linear and logarithmic models to determine if a pattern exists. The correlation coefficients are quite small for all models (Table 4.7), indicating no significant trend in either ${ }^{187} \mathrm{Os} /{ }^{188}$ Os or Os concentrations with distance from contact.

Both dike samples have low Os concentrations $(28 \mathrm{pg} / \mathrm{g}$ for the lower dike and $3.2 \mathrm{pg} / \mathrm{g}$ for the upper dike), but the two dike samples had very different ${ }^{187} \mathrm{Os} /{ }^{188}$ Os ratios $(0.23$ for the lower dike and 2.31 or the upper dike).

Rhenium concentrations do not show a significant change with distance from contact (Figure 4.9). Again the correlation coefficients are low, but higher for a logarithmic fit $\left(\mathrm{R}^{2}=0.38\right)$ than for a linear fit $\left(\mathrm{R}^{2}=0.26\right)$. This indicates relatively little correlation between the distance from the contact and Re concentrations. Samples in the weathered band (located between $\sim 2.5$ and $\sim 5.5 \mathrm{~m}$ from the contact) that have lower $\mathrm{Pb}$ concentrations also show significantly lower Re concentrations. Jaffe et al. (2002) examined Re mobilization during weathering of black shale and found almost quantitative removal during oxic weathering. This supports the idea that the decrease in Re concentrations through that light-colored band could have been caused by weathering. Both dike samples have very low Re concentrations (204 pg/g for the lower dike, $381 \mathrm{pg} / \mathrm{g}$ for the upper dike) compared to the adjacent shales. 
Rhenium concentrations are used to calculate the age-corrected osmium concentrations and isotopic compositions to the time of the late Oligocene to early Miocene intrusion ( 24.16 $\pm 1.01 \mathrm{Ma}$; Scott et al., 1990), as well as the time of sediment deposition in the late Cretaceous, $\sim 70 \mathrm{Ma}$ (Johnson and Finn, 2001). The fact that the Os isotopic composition of the samples that have experienced Re loss through weathering is similar to neighboring samples indicates that the Re loss must have happened recently, a finding in accord with the results of the study of a subaerial weathering profile in organic-rich shales (Jaffe et al., 2002). As a result, an average Re concentration of the unweathered samples $(10.7 \mathrm{ng} / \mathrm{g})$ was used to age-correct the osmium concentrations and isotope ratios of the weathered samples. Very little change in the overall trend was noted after age-correction. Correlation coefficients are similar to those not corrected for age (Table 4.8). However, for the isotopic composition all of the correlations decreased with the exception of the linear correlation with the ${ }^{187} \mathrm{Os} /{ }^{188} \mathrm{Os}$ of group B. Age corrections for Os concentrations had a small $(<3 \%)$ effect, and thus had almost no effect on the regression coefficients. The average ${ }^{187} \mathrm{Os} /{ }^{188} \mathrm{Os}$ of the group A samples $(0.84)$ is slightly more radiogenic than seawater at the time of deposition ( 0.6; Peucker-Ehrenbrink and Ravizza, 2012).

The non-corrected values are tested to see if they can represent an isochron. If the linear correlation is interpreted as an isochron, the calculated age of the sediments is $179 \pm 7 \mathrm{Ma}$ (one standard deviation error; Figure 4.11). This does not match with previous studies of the Pierre Shale indicating a late Cretaceous depositional age. Samples from the weathered band were not included in these calculations due to the recent loss in Re.

Instead of an isochron relationship, the distribution must represent two-component mixing at the time of deposition (Figure 4.12). The data was age-corrected to the time of deposition and once again plotted on a $70 \mathrm{Myr}$ reference line. If mixing of two components with 
different initial isotope compositions did not occur, the samples would all have identical ${ }^{187} \mathrm{Os} /{ }^{188} \mathrm{Os}$. Instead, the samples form a two-component mixing line with one end member likely representing contemporaneous seawater composition (i.e. hydrogenous end member) and the other likely representing detrital input (Figure 4.12). The ${ }^{187} \mathrm{Os} /{ }^{188} \mathrm{Os}$ for the hydrogenous component is set by the ${ }^{187} \mathrm{Os} /{ }^{188}$ Os value for seawater at the time ( $\sim .6$; Peucker-Ehrenbrink and Ravizza, 2012). The ${ }^{187} \mathrm{Os} /{ }^{188} \mathrm{Os}$ of UCC $70 \mathrm{Ma}$ is less well known, but is assumed to be similar to the modern UCC value of $\sim 1.4$ (Peucker-Ehrenbrink and Jahn, 2001). Based on these constraints, the Os in the group A sediments is derived predominantly ( $74 \%)$ from the hydrogenous component, whereas the Os from the group B sediments is almost entirely $(\sim 89 \%)$ detrital in origin (further discussion follows below).

\subsection{Discussion}

\subsubsection{Organic carbon depletion}

The Raton Basin samples, despite their dark appearance, are relatively poor in organic matter over the interval sampled compared to "typical" organic rich shales (see Chapter 2) or Raton Basin coals (20-35 wt.\% TOC; Cooper, 2007). No TOC data are available for Pierre Shales within the Raton Basin; however, estimates of the Pierre Shale from other locations (particularly the Sharon Springs member in Wyoming and Montana) indicate TOC values ranging from $\sim 2$ to $\sim 7$ wt.\% (Dean and Arthur, 1989; Kennedy et al., 2002; Peters and Cassa, 1994). The farthest samples from the dike in our profile may thus be considered a reasonable analog for the NAMP (mean TOC of 1.4 wt.\%; Svensen et al., 2004). While there is a large decrease in organic carbon concentration near the contact to the dike, we did not sample far enough from the dike contact to observe the plateau in TOC concentrations, and even the farthest samples from the contact have TOC concentrations of only about $1 \mathrm{wt} . \%$, which may be lower 
than the initial TOC concentration. In addition, we did not observe the changes in $\delta^{13} \mathrm{C}$ around the contact as identified by Cooper et al. (2007), who found a strong correlation between $\delta^{13} \mathrm{C}$ and TOC. The range of $\delta^{13} \mathrm{C}$ found in that study, however, varied between $-25.2 \%$ and $-26.6 \%$, similar to the uncertainty in our isotope data.

Despite the large changes in TOC concentrations over the profile, the relatively high TOC concentrations in the Sharon Springs member might indicate that the full extent of carbon loss may not be expressed within our profile and instead the measured samples approached the edge of the contact metamorphic aureole but were confined to within it. This interpretation is consistent with previous studies, which found that the thickness of metamorphic aureoles (rocks heated above $100^{\circ} \mathrm{C}$ ) can be larger than the thickness of the sill on both sides when intruded into shales (Galushkin, 1997). Crelling and Dutcher (1968) and Bostick and Pawlewicz (1984) similarly found that the width of a metamorphic aureole was similar in size to the width of mafic intrusions into coal beds in the Raton Basin, based on vitrinite reflectance profiles. Cooper et al. (2007) argue, on the other hand, that production of pyrolitic carbon from coals in the Raton Basin is restricted to one third to one half of the width of a dike or sill, respectively. The Eagle Rock dike is $\sim 8.8 \mathrm{~m}$ wide and the shales were only sampled to a distance of $8.9 \mathrm{~m}$ from the contact, possibly not fully outside of the range of the metamorphic aureole. A more conclusive study would require resampling the outcrop and taking samples from the farthest point sampled here to 2-3 dike widths away from the dike contact (Bostick and Pawlewicz, 1984).

\subsubsection{Authigenic enrichment of redox sensitive elements}

Redox-sensitive elements such as uranium, osmium, and rhenium can occur in multiple redox states and become less soluble in suboxic to reducing conditions leading to authigenic enrichment of these elements in organic-rich marine sediments (e.g. Cohen et al., 1999; Colodner 
et al., 1993; Ravizza and Turekian, 1989; Ravizza et al., 1991; Selby and Creaser, 2003) over average continental crust (Taylor and McLennan, 1985; McLennan, 2001). Rhenium is especially sensitive to changing redox conditions, as it is one of the most enriched redoxsensitive trace elements over detrital background concentrations in suboxic to anoxic sediments (Crusius and Thomson, 2000; Morford and Emerson, 1999).

Digestion of the samples in the HPA was incomplete because HF cannot be used in the quartz glass digestion vials, leaving primarily the siliciclastic component intact. In organic-rich sediments, the majority of the Re and Os inventories are authigenic, and incomplete digestion of detrital material is therefore assumed to have little impact on the overall amount of these elements in solution (Nozaki et al., 2012). Certain lithogenic minerals, such as molybdenites, contain relatively high concentrations of Re and Os (Miller et al, 2011; Noddack and Noddack, 1931; Suzuki et al., 1993) due to their chalcophilic behavior (Goldschmidt, 1922). Incomplete digestion of these phases could lead to the discrepancies between the two groups ("Group A" and "Group B"). However, various types of digestion procedures have been performed on organicrich mudrocks to digest different fractions of the bulk sediment (vs. just the authigenic fraction) and have yielded similar ${ }^{187} \mathrm{Os} /{ }^{188} \mathrm{Os}$ regardless of the aggressiveness of the digestion procedure used (Wieczorek et al., 2013), indicating incomplete digestion should not affect ${ }^{187} \mathrm{Os} /{ }^{188} \mathrm{Os}$.

The differences in group A and group B Os isotope compositions are instead explained by mixing between a less radiogenic hydrogenous component and a more radiogenic detrital component with ${ }^{187} \mathrm{Os} /{ }^{188} \mathrm{Os}$ values typical of upper continental crust at the time of deposition. Group A sediments are dominated by the hydrogenous osmium while group B host almost entirely detrital osmium. While we tried to sample along a single sedimentary horizon, the samples extracted from the outcrop are about $5-10 \mathrm{~cm}$ thick. Cutting, cleaning and hand-picking 
during sample preparation may have introduced biases in the representation of the sedimentary layers in the final powdered samples. Differences in the exact bedding planes represented in the sample powders may account for the observed bimodal distribution, as changes in detrital input to the basin and the intensity of hydrogenous enrichment likely varied with time.

$\mathrm{U} / \mathrm{Th}$ ratios of the shales ranged from 0.37 to 0.46 with an average of 0.41 . This indicates little authigenic enrichment of $U$ over average continental crust that typically has a $\mathrm{U} / \mathrm{Th}$ ratio of $\sim 0.15$ to $\sim 0.26$ (Carpentier et al., 2013; McLennan, 2001). Osmium and Re concentrations, which range from 91 to $262 \mathrm{pg} / \mathrm{g}$ and 4.8 to $13 \mathrm{ng} / \mathrm{g}$ respectively, are likewise elevated relative to average upper continental crust, for which Os concentrations have been estimated at 31 and $50 \mathrm{pg} / \mathrm{g}$, whereas Re concentrations in average UCC have been estimated between $200 \mathrm{pg} / \mathrm{g}$ and 2 ng/g (Peucker-Ehrenbrink and Jahn, 2001; Esser and Turekian, 1993; Schmidt et al., 1997; Sun et al., 2003; Taylor and McLennan, 1985). The measured Os and Re concentrations, however, are low for organic-rich shales that have average Os concentrations of $\sim 586 \mathrm{pg} / \mathrm{g}$ and Re concentrations of $\sim 35 \mathrm{ng} / \mathrm{g}$ (see Chapter 2).

The mild authigenic enrichment of Re, Os, and U compared to oxic continental crustal sediments indicates that the sediments may have been deposited under reducing conditions. Concentrations of these elements likely record depositional concentrations rather than postdepositional metamorphic alteration reflected in the organic carbon profile, as the concentration profiles of these elements in the outcrop are invariant with respect to distance from the intrusive contact.

\subsubsection{Mobilization of osmium and lead and implications for the PETM}

No significant changes in concentration are observed for $\mathrm{Os}$ or $\mathrm{Pb}$ across the profile. While I recognize that uncertainty in the data may mask small changes in concentration, the lack 
of any consistent trend in concentration as well as the poor correlation between concentrations and organic carbon removal indicate that these elements may not be mobilized during contactmetamorphic alteration. Without a control sample far enough away from the aureole, it is difficult to unequivocally state that metamorphic processes triggered by intrusions have not altered the primary element concentrations. However, while I recognize the limitations, I conclude that there is no evidence for $\mathrm{Os}$ or $\mathrm{Pb}$ mobilization in the Tinaja outcrop.

The hypothesis that the Os isotope excursion at the PETM might be at least partially explained by Os released from organic-rich shales during contact metamorphism requires at least partial mobilization of Os. While I recognize the limitations of the Raton Basin dataset, Os loss is not observed. In addition, the lack of mobilization of $\mathrm{Pb}$ near the intrusive contact indicates that the U-Th-Pb systematics of marine sediments will not be useful in constraining whether the Svensen et al. (2004) hypothesis is valid.

\subsection{Conclusion}

I sampled the dark-gray Pierre Shale in the Raton Basin along a bedding plane in a metamorphic aureole in order to determine the behavior of the Re-Os and $\mathrm{U}-\mathrm{Th}-\mathrm{Pb}$ isotope systems during post-depositional contact-metamorphic alteration. Approximately 1 wt. $\%$ of TOC was lost over the profile; however, the plateau in TOC concentration was not observed and significantly more organic carbon may have been lost. Based on the TOC profile, I suspect that we may not have sampled far enough away from the intrusive contact, and instead sampled within the edge of the metamorphic aureole. I do observe authigenic enrichment of Re, Os, and - to some extent $-\mathrm{U}$ over average continental crustal material. The findings are suggestive of little to no mobilization of $\mathrm{Re}, \mathrm{Os}$, and $\mathrm{Pb}$ during contact-metamorphic alteration, indicating we may not be able to use the U-Th- $\mathrm{Pb}$ isotope systems to demonstrate that the release of light 
carbon at the PETM was caused by magmatic intrusions into organic-rich sediments. The apparently well-preserved Re-Os isotope systematics of the profile do not support the notion that release of radiogenic sedimentary Os from the contact-metamorphic aureoles of magmatic intrusions contributed significantly to the observed excursion to more radiogenic ${ }^{187} \mathrm{Os} /{ }^{188} \mathrm{Os}$ in seawater during the PETM.

I do recognize that the Raton Basin is not a perfect analog for the NAMP due to the terrestrial nature of the intrusions. Submarine pore fluids may assist in the mobilization and removal of $\mathrm{Pb}$ and Os during contact metamorphism. Additionally, the higher salinity of the seawater in Guaymas Basin sediments may result in increased metal mobility (Du Laing et al., 2008). In the next chapter, I therefore examine a potentially more suitable submarine analog: contact-metamorphic aureoles in the organic-rich sediments from the Guaymas Basin. 


\begin{tabular}{|c|c|c|c|c|c|c|c|c|}
\hline Sample & $\begin{array}{l}\text { Distance from } \\
\text { contact }(\mathrm{cm})\end{array}$ & ${ }^{187} \mathrm{Os} /{ }^{188} \mathrm{Os}$ & ${ }^{187} \mathrm{Os} /{ }^{188}$ Os error & $\begin{array}{c}{[\mathrm{Os}]} \\
(\mathrm{pg} / \mathrm{g})\end{array}$ & $\begin{array}{l}\text { [Os] } \\
\text { error }\end{array}$ & $\begin{array}{c}{[\mathrm{Re}]} \\
(\mathrm{pg} / \mathrm{g})\end{array}$ & [Re] error & ${ }^{187} \mathrm{Re} /{ }^{188} \mathrm{Os}$ \\
\hline PI01 & 2.54 & 1.257 & 0.005 & 193.8 & 0.5 & 11699 & 82 & 334 \\
\hline $\mathrm{PIO2}$ & 5.08 & 2.343 & 0.011 & 123.8 & 0.3 & 13244 & 93 & 665 \\
\hline $\mathrm{PIO3}$ & 10.16 & 2.263 & 0.009 & 102.8 & 0.4 & 10396 & 73 & 623 \\
\hline $\mathrm{PIO4}$ & 17.78 & 1.080 & 0.007 & 236.0 & 0.7 & 8429 & 59 & 194 \\
\hline PI05 & 25.40 & 1.300 & 0.006 & 247.4 & 0.6 & 13475 & 94 & 303 \\
\hline $\mathrm{PI06}$ & 33.02 & 1.120 & 0.006 & 221.2 & 0.6 & 9462 & 66 & 233 \\
\hline $\mathrm{PI07}$ & 40.64 & 1.039 & 0.005 & 261.8 & 1.3 & 9265 & 65 & 191 \\
\hline $\mathrm{PI08}$ & 50.80 & 1.317 & 0.007 & 218.3 & 0.7 & 11261 & 79 & 287 \\
\hline PI09 & 71.12 & 1.246 & 0.004 & 230.6 & 0.7 & 10628 & 74 & 255 \\
\hline PI10 & 91.44 & 2.268 & 0.015 & 121.0 & 0.3 & 11195 & 78 & 571 \\
\hline PI11 & 124.46 & 2.293 & 0.009 & 91.3 & 1.1 & 9071 & 63 & 614 \\
\hline $\mathrm{PI} 12$ & 251.46 & 1.190 & 0.003 & 245.5 & 2.2 & 11558 & 81 & 258 \\
\hline $\mathrm{PI} 13$ & 327.66 & 0.876 & 0.013 & 254.8 & 11.7 & 4785 & 33 & 99 \\
\hline $\mathrm{PI} 14$ & 416.56 & 1.081 & 0.002 & 247.3 & 2.4 & 5709 & 40 & 125 \\
\hline PI15 & 548.64 & 2.147 & 0.013 & 97.9 & 0.8 & 7827 & 55 & 487 \\
\hline PI16 & 802.64 & 1.072 & 0.004 & 221.9 & 2.6 & 7673 & 54 & 187 \\
\hline PI17 & 891.54 & 2.191 & 0.010 & 98.8 & 0.2 & 9362 & 66 & 580 \\
\hline Lower dike & & 0.228 & 0.001 & 28.3 & 0.1 & 204 & 1 & 35 \\
\hline Upper dike & & 2.314 & 0.017 & 3.2 & 0.0 & 381 & 3 & 735 \\
\hline
\end{tabular}

Table 4.1 Present day Re and Os concentrations and isotope ratios of the Raton Basin samples. Errors are defined by a single standard deviation on the measurement. 


\begin{tabular}{|c|c|c|c|c|c|c|c|c|}
\hline Sample & $\begin{array}{c}\text { Distance from } \\
\text { contact }(\mathrm{cm})\end{array}$ & ${ }^{187} \mathrm{Os} /{ }^{188} \mathrm{Os}$ & ${ }^{187} \mathrm{Os} /{ }^{188}$ Os error & $\begin{array}{c}\mathrm{Os}] \\
(\mathrm{pg} / \mathrm{g})\end{array}$ & $\begin{array}{l}\text { [Os] } \\
\text { error }\end{array}$ & $\begin{array}{c}{[R e]} \\
(\mathrm{pg} / \mathrm{g}) \\
\end{array}$ & [Re] error & ${ }^{187} \mathrm{Re} /{ }^{188} \mathrm{Os}$ \\
\hline PI01 & 2.54 & 1.122 & 0.005 & 190.8 & 0.5 & 11704 & 82 & 334 \\
\hline $\mathrm{PIO2}$ & 5.08 & 2.075 & 0.010 & 120.4 & 0.3 & 13250 & 93 & 665 \\
\hline $\mathrm{PI03}$ & 10.16 & 2.012 & 0.008 & 100.1 & 0.4 & 10400 & 73 & 624 \\
\hline PI04 & 17.78 & 1.002 & 0.006 & 233.8 & 0.7 & 8433 & 59 & 194 \\
\hline $\mathrm{PI05}$ & 25.40 & 1.178 & 0.006 & 244.0 & 0.6 & 13481 & 94 & 303 \\
\hline PI06 & 33.02 & 1.026 & 0.005 & 218.7 & 0.6 & 9466 & 66 & 233 \\
\hline PI07 & 40.64 & 0.962 & 0.004 & 259.4 & 1.3 & 9269 & 65 & 191 \\
\hline $\mathrm{PI08}$ & 50.80 & 1.201 & 0.007 & 215.4 & 0.7 & 11266 & 79 & 288 \\
\hline PI09 & 71.12 & 1.143 & 0.004 & 227.9 & 0.7 & 10632 & 74 & 255 \\
\hline PI10 & 91.44 & 2.038 & 0.013 & 118.1 & 0.2 & 11199 & 78 & 571 \\
\hline PI11 & 124.46 & 2.046 & 0.008 & 89.0 & 1.1 & 9074 & 64 & 615 \\
\hline $\mathrm{PI} 12$ & 251.46 & 1.086 & 0.002 & 242.6 & 2.2 & 11563 & 81 & 259 \\
\hline $\mathrm{PI} 13$ & 327.66 & 0.836 & 0.012 & 253.5 & 11.6 & 4787 & 34 & 99 \\
\hline PI14 & 416.56 & 1.031 & 0.002 & 245.9 & 2.4 & 5711 & 40 & 125 \\
\hline PI15 & 548.64 & 1.951 & 0.012 & 95.9 & 0.8 & 7830 & 55 & 488 \\
\hline PI16 & 802.64 & 0.997 & 0.003 & 219.9 & 2.6 & 7676 & 54 & 187 \\
\hline PI17 & 891.54 & 1.958 & 0.009 & 96.4 & 0.2 & 9366 & 66 & 580 \\
\hline Lower dike & & 0.213 & 0.001 & 28.3 & 0.1 & 204 & 1 & 35 \\
\hline Upper dike & & 2.018 & 0.015 & 3.1 & 0.0 & 381 & 3 & 735 \\
\hline
\end{tabular}

Table 4.2 Re and Os concentrations and isotope ratios of the Raton Basin samples age-corrected to the time of the intrusion (24.16 $\pm 1.01 \mathrm{Ma}$; Scott et al., 1990). Errors are defined by a single standard deviation on the measurement. Age corrections are calculated using a ${ }^{187}$ Re decay constant of $1.666 \times 10^{-11} \mathrm{a}^{-1}$ (Smoliar et al., 1996). 


\begin{tabular}{|c|c|c|c|c|c|c|c|c|}
\hline Sample & $\begin{array}{l}\text { Distance from } \\
\text { contact }(\mathrm{cm})\end{array}$ & ${ }^{187} \mathrm{Os} /{ }^{188} \mathrm{Os}$ & ${ }^{187}$ Os $/{ }^{188}$ Os error & $\begin{array}{c}\mathrm{Os}] \\
(\mathrm{pg} / \mathrm{g})\end{array}$ & $\begin{array}{l}\text { [Os] } \\
\text { error }\end{array}$ & $\begin{array}{c}{[R e]} \\
(\mathrm{pg} / \mathrm{g})\end{array}$ & [Re] error & ${ }^{187} \mathrm{Re} /{ }^{188} \mathrm{Os}$ \\
\hline PI01 & 2.54 & 0.811 & 0.003 & 183.8 & 0.5 & 11715 & 82 & 335 \\
\hline $\mathrm{PIO2}$ & 5.08 & 1.456 & 0.007 & 112.6 & 0.3 & 13262 & 93 & 666 \\
\hline $\mathrm{PI03}$ & 10.16 & 1.431 & 0.006 & 94.0 & 0.3 & 10410 & 73 & 625 \\
\hline $\mathrm{PIO4}$ & 17.78 & 0.822 & 0.005 & 228.8 & 0.7 & 8440 & 59 & 194 \\
\hline PI05 & 25.40 & 0.896 & 0.004 & 236.0 & 0.6 & 13493 & 94 & 303 \\
\hline $\mathrm{PI06}$ & 33.02 & 0.809 & 0.004 & 213.1 & 0.6 & 9475 & 66 & 233 \\
\hline $\mathrm{PI07}$ & 40.64 & 0.784 & 0.004 & 253.9 & 1.3 & 9277 & 65 & 191 \\
\hline $\mathrm{PI08}$ & 50.80 & 0.934 & 0.005 & 208.7 & 0.7 & 11276 & 79 & 288 \\
\hline PI09 & 71.12 & 0.906 & 0.003 & 221.6 & 0.7 & 10642 & 74 & 255 \\
\hline PI10 & 91.44 & 1.507 & 0.010 & 111.5 & 0.2 & 11210 & 78 & 572 \\
\hline PI11 & 124.46 & 1.473 & 0.006 & 83.6 & 1.0 & 9083 & 64 & 616 \\
\hline $\mathrm{PI} 12$ & 251.46 & 0.845 & 0.002 & 235.7 & 2.1 & 11574 & 81 & 259 \\
\hline $\mathrm{PI} 13$ & 327.66 & 0.744 & 0.011 & 250.7 & 11.5 & 4791 & 34 & 100 \\
\hline PI14 & 416.56 & 0.914 & 0.002 & 242.5 & 2.4 & 5716 & 40 & 125 \\
\hline PI15 & 548.64 & 1.498 & 0.009 & 91.2 & 0.7 & 7837 & 55 & 488 \\
\hline PI16 & 802.64 & 0.823 & 0.003 & 215.4 & 2.5 & 7683 & 54 & 188 \\
\hline PI17 & 891.54 & 1.418 & 0.006 & 90.9 & 0.2 & 9375 & 66 & 581 \\
\hline
\end{tabular}

Table 4.3 Re and Os concentrations and isotope ratios of the Raton Basin samples age-corrected to the time of deposition ( $70 \mathrm{Ma})$.

Errors are defined by a single standard deviation on the measurement. Age corrections are calculated using a ${ }^{187}$ Re decay constant of $1.666 \times 10^{-11} \mathrm{a}^{-1}$ (Smoliar et al., 1996). 


\begin{tabular}{|c|c|c|c|c|c|c|c|c|c|}
\hline Sample & $\begin{array}{l}\text { Distance from } \\
\text { contact }(\mathrm{cm})\end{array}$ & TOC (wt.\%) & TOC error & $\delta^{13} \mathrm{C}$ & $\delta^{13} \mathrm{C}$ error & $\% \mathrm{~N}$ & $\% \mathrm{~N}$ error & $\delta^{15} \mathrm{~N}$ & $\delta^{15} \mathrm{~N}$ error \\
\hline PI01 & 2.54 & 0.040 & 0.006 & -17.9 & 0.8 & 0.017 & 0.001 & -3.5 & 4.5 \\
\hline $\mathrm{PIO2}$ & 5.08 & 0.038 & 0.008 & -24.4 & 3.3 & 0.014 & & 6.6 & \\
\hline $\mathrm{PI03}$ & 10.16 & 0.067 & 0.016 & -25.8 & 3.7 & 0.038 & 0.008 & 0.2 & 10.1 \\
\hline $\mathrm{PIO4}$ & 17.78 & 0.036 & 0.005 & -24.7 & 3.0 & 0.018 & 0.000 & 2.2 & 1.2 \\
\hline PI05 & 25.40 & 0.044 & 0.007 & -20.0 & 0.4 & 0.020 & & 0.2 & \\
\hline PI06 & 33.02 & 0.054 & 0.010 & -19.9 & 3.3 & & & & \\
\hline $\mathrm{PI07}$ & 40.64 & 0.038 & 0.005 & -23.3 & 1.0 & 0.014 & 0.002 & 8.4 & 11.6 \\
\hline $\mathrm{PI08}$ & 50.80 & 0.048 & 0.006 & -22.3 & 1.6 & & & & \\
\hline PI09 & 71.12 & 0.056 & 0.008 & -26.7 & 0.5 & 0.020 & & 11.2 & \\
\hline PI10 & 91.44 & 0.041 & 0.001 & -20.4 & 0.7 & & & & \\
\hline PI11 & 124.46 & 0.033 & 0.004 & -24.8 & 2.9 & 0.013 & & -0.2 & \\
\hline $\mathrm{PI} 12$ & 251.46 & 0.057 & 0.024 & -29.1 & 0.2 & 0.027 & 0.005 & -0.8 & 8.6 \\
\hline $\mathrm{PI} 13$ & 327.66 & 0.079 & 0.016 & -27.2 & 0.9 & 0.023 & 0.002 & -7.2 & 1.1 \\
\hline PI14 & 416.56 & 0.061 & 0.010 & -26.4 & 1.0 & 0.031 & 0.001 & -2.3 & 5.4 \\
\hline PI15 & 548.64 & 0.135 & 0.005 & -24.4 & 0.6 & 0.026 & 0.002 & -5.9 & 4.4 \\
\hline PI16 & 802.64 & 0.821 & 0.070 & -24.6 & 0.1 & 0.043 & 0.005 & 0.8 & 0.4 \\
\hline PI17 & 891.54 & 1.001 & 0.039 & -24.7 & 0.3 & 0.050 & 0.008 & 1.8 & 3.3 \\
\hline Lower dike & & 0.188 & 0.004 & -27.4 & 0.0 & 0.006 & 0.001 & -4.1 & 0.4 \\
\hline Upper dike & & 0.014 & 0.002 & -33.1 & 4.2 & 0.009 & 0.001 & -2.1 & 1.6 \\
\hline
\end{tabular}

Table 4.4 Total organic carbon and total nitrogen concentrations of the Raton Basin samples and the respective isotope compositions relative to PDB. Errors are defined by twice the standard deviation on the measurement. Samples that only a single replicate do not have associated errors. 


\begin{tabular}{|c|c|c|c|c|c|c|c|c|c|c|c|c|c|c|c|}
\hline Sample & As & $\mathrm{Ba}$ & $\mathrm{Be}$ & $\mathrm{Bi}$ & $\mathrm{Cd}$ & $\mathrm{Ce}$ & Co & $\mathrm{Cr}$ & Cs & $\mathrm{Cu}$ & Dy & $\mathrm{Er}$ & $\mathrm{Eu}$ & $\mathrm{Ga}$ & $\mathrm{Gd}$ \\
\hline PI01 & 6.697 & 544.2 & 2.437 & 0 & 1.623 & 77.15 & 13.22 & 86.02 & 11.67 & 31.25 & 4.931 & 2.698 & 1.383 & 23.66 & 5.454 \\
\hline $\mathrm{PIO2}$ & 6.613 & 562.3 & 2.277 & 0 & 1.747 & 76.08 & 12.74 & 84.7 & 11.37 & 35.68 & 4.797 & 2.628 & .353 & 23.38 & 5.393 \\
\hline PI03 & 6.125 & 555.5 & 2.401 & 0 & 1.485 & 73.29 & 12.11 & 83.23 & 9.97 & 32.84 & 4.529 & 2.543 & 1.302 & 23.96 & 4.966 \\
\hline $\mathrm{PIO4}$ & 8.951 & 540.8 & 2.394 & 0 & 1.687 & 71.78 & 12.58 & 84.17 & 6.962 & 30.9 & 4.413 & 2.544 & 1.212 & 24.41 & 4.64 \\
\hline PI05 & 9.118 & 558.1 & 2.526 & 0.121 & 1.936 & 80.11 & 13.77 & 87.45 & 12.09 & 37.19 & 5.175 & 2.801 & 1.45 & 24.61 & 5.599 \\
\hline PI06 & 9.017 & 578 & 2.388 & 0.125 & 1.858 & 71.67 & 12.23 & 85.27 & 7.789 & 34.68 & 4.494 & 2.573 & 1.24 & 23.87 & 4.775 \\
\hline PI07 & 10.13 & 543.5 & 2.314 & 0.124 & 1.5 & 69.14 & 11.95 & & 7.997 & & 96 & 2.499 & 1.243 & 35 & 4.749 \\
\hline PI08 & 11.15 & 508.8 & 2.539 & 0.117 & 1.607 & 70.25 & 12.73 & 83.02 & 9.371 & 34.34 & 4.45 & 2.584 & 1.288 & 23.44 & 4.92 \\
\hline PI09 & 11.97 & 538.3 & 2.375 & 0.101 & 2.172 & 75.05 & 12.84 & 85.97 & 9.785 & 33.88 & 4.711 & 2.631 & 1.309 & 24.02 & 5.072 \\
\hline PI10 & 10.92 & 537.1 & 2.43 & 0 & 1.918 & 67.49 & 11.13 & 91.08 & 11.27 & 29.89 & 4.767 & 2.563 & 1.396 & 21.4 & 5.323 \\
\hline PI11 & 11.33 & 552.5 & 2.237 & 0 & 1.578 & 71.93 & 12.57 & 86.28 & 8.344 & 28.42 & 4.556 & 2.569 & 1.273 & 24 & 4.765 \\
\hline $\mathrm{PI} 12$ & 2.164 & 1225 & 2.133 & 0 & 2.134 & 68.97 & 10.82 & 91.78 & 10.8 & 32.55 & 4.669 & 2.572 & 1.393 & 21.11 & 5.32 \\
\hline $\mathrm{PI} 14$ & 2.19 & 695.4 & 2.066 & 0 & 1.493 & 66.78 & 10.59 & 89.25 & 6.885 & 33.03 & 4.626 & 2.544 & 1.372 & 19.81 & 4.988 \\
\hline PI13 & 4.746 & 515 & 2.28 & 0.151 & 2.721 & 84.16 & 18.2 & 73.85 & 1.24 & 37.8 & 6.473 & 3.233 & 1.695 & 16.99 & 7.572 \\
\hline PI15 & 3.014 & 588.1 & 2.08 & 0.558 & 1.642 & 89.95 & 12.37 & 85.18 & 1.046 & 35.6 & 5.052 & 2.666 & 1.417 & 19.4 & 5.993 \\
\hline PI16 & 9.216 & 838.6 & 2.234 & 0.377 & 1.975 & 76.95 & 11.91 & 89.79 & 1.396 & 37.18 & 4.762 & 2.692 & 1.497 & 22.42 & 5.317 \\
\hline PI17 & 20.96 & 1044 & 2.107 & 0.37 & 1.953 & 79.05 & 12.11 & 92.53 & 2.078 & 36.53 & 5.065 & 2.723 & 1.501 & 20.84 & 5.779 \\
\hline $\begin{array}{c}\text { Typical } \\
\text { uncertainties }\end{array}$ & $25 \%$ & 5 & $25 \%$ & $25 \%$ & $15 \%$ & $5 \%$ & $10 \%$ & $5 \%$ & $0 \%$ & $10 \%$ & $5 \%$ & $5 \%$ & $5 \%$ & $5 \%$ & $5 \%$ \\
\hline
\end{tabular}




\begin{tabular}{|c|c|c|c|c|c|c|c|c|c|c|c|c|c|c|c|}
\hline Sample & $\mathrm{Ge}$ & $\mathrm{Hf}$ & $\mathrm{Ho}$ & $\ln$ & La & $\mathrm{Lu}$ & Mo & $\mathrm{Nb}$ & $\mathrm{Nd}$ & $\mathrm{Ni}$ & $\mathrm{Pb}$ & $\mathrm{Pr}$ & $\mathrm{Rb}$ & Sc & $\mathrm{Sb}$ \\
\hline PI01 & 1.603 & 3.916 & 0.958 & 0 & 38.29 & 0.425 & 8.726 & 13.1 & 33.82 & 41.15 & 29.3825 & 9.094 & 144.9 & 16.77 & 0.889 \\
\hline $\mathrm{PIO2}$ & 1.566 & 3.891 & 0.939 & 0 & 37.81 & 0.423 & 8.865 & 12.95 & 33.3 & 41.7 & 29.2707 & 8.951 & 142 & 16.73 & 0.859 \\
\hline $\mathrm{PIO3}$ & 1.539 & 3.859 & 0.91 & 0 & 36.8 & 0.41 & 7.493 & 12.99 & 31.54 & 38.37 & 28.356 & 8.543 & 144.2 & 16.25 & 1.162 \\
\hline $\mathrm{PIO4}$ & 1.558 & 3.978 & 0.875 & 0 & 36.43 & 0.421 & 6.59 & 13.59 & 30.22 & 38.77 & 28.5889 & 8.346 & 149.6 & 15.62 & 1.922 \\
\hline PI05 & 1.645 & 4 & 1.004 & 0 & 39.92 & 0.46 & 9.188 & 13.51 & 35.04 & 44.63 & 30.5037 & 9.48 & 143.5 & 16.9 & 1.499 \\
\hline PI06 & 1.696 & 3.851 & 0.889 & 0 & 36.41 & 0.425 & 7.114 & 13.34 & 30.44 & 39.18 & 28.2568 & 8.394 & 147.3 & 15.67 & 2.248 \\
\hline $\mathrm{PI07}$ & 1.551 & 3.836 & 0.86 & 0.088 & 36.4 & 0.403 & 6.571 & 13.21 & 30.59 & 38.03 & 27.8262 & 8.35 & 143.9 & 15.64 & 2.318 \\
\hline $\mathrm{PI08}$ & 1.663 & 3.76 & 0.893 & 0.094 & 36.83 & 0.408 & 7.924 & 12.82 & 31.93 & 41 & 28.6827 & 8.586 & 143.7 & 16.41 & 2.507 \\
\hline PI09 & 1.58 & 3.946 & 0.926 & 0 & 37.77 & 0.428 & 8.073 & 13.44 & 32.16 & 41.64 & 29.227 & 8.76 & 145.2 & 16 & 2.003 \\
\hline PI10 & 1.614 & 3.508 & 0.925 & 0.099 & 35.66 & 0.398 & 5.888 & 12.22 & 31.88 & 40.75 & 23.5707 & 8.433 & 132.6 & 15.44 & 2.818 \\
\hline PI11 & 1.632 & 3.969 & 0.89 & 0 & 36.66 & 0.422 & 6.808 & 13.76 & 30.52 & 39.28 & 28.2659 & 8.405 & 148 & 15.56 & 1.974 \\
\hline PI12 & 1.195 & 3.551 & 0.906 & 0 & 34.55 & 0.41 & 7.203 & 12.79 & 31.01 & 40.96 & 24.6619 & 8.288 & 158.8 & 15.28 & 0.521 \\
\hline PI14 & 1.301 & 3.64 & 0.9 & 0.07 & 33.36 & 0.403 & 5.73 & 12.9 & 30.44 & 39.2 & 21.0333 & 8.088 & 113.9 & 14.24 & 0.479 \\
\hline PI13 & 1.027 & 3.355 & 1.2 & 0.119 & 39 & 0.443 & 5.209 & 11.39 & 40.77 & 66.1 & 17.5645 & 10.49 & 56.69 & 15.41 & 0.557 \\
\hline PI15 & 1.205 & 3.582 & 0.964 & 0.085 & 51.33 & 0.413 & 6.003 & 12.27 & 37.63 & 43.48 & 22.1407 & 10.31 & 74.91 & 16.15 & 1.083 \\
\hline PI16 & 1.582 & 3.895 & 0.945 & 0.082 & 38.8 & 0.426 & 5.522 & 12.94 & 33.91 & 41.94 & 27.8829 & 9.104 & 79.7 & 15.27 & 2.475 \\
\hline PI17 & 1.381 & 3.695 & 0.98 & 0.091 & 40.63 & 0.429 & 5.878 & 12.94 & 34.7 & 41.66 & 26.3717 & 9.268 & 104.5 & 15.5 & 2.318 \\
\hline $\begin{array}{c}\text { Typical } \\
\text { uncertainties }\end{array}$ & $8 \%$ & $10 \%$ & $10 \%$ & $25 \%$ & $5 \%$ & $5 \%$ & $10 \%$ & $5 \%$ & $5 \%$ & $25 \%$ & $5 \%$ & $5 \%$ & $5 \%$ & $15 \%$ & $10 \%$ \\
\hline
\end{tabular}




\begin{tabular}{ccccccccccccccc}
\hline Sample & $\mathrm{Sm}$ & $\mathrm{Sn}$ & $\mathrm{Sr}$ & $\mathrm{Ta}$ & $\mathrm{Tb}$ & $\mathrm{Th}$ & $\mathrm{Tm}$ & $\mathrm{U}$ & $\mathrm{V}$ & $\mathrm{W}$ & $\mathrm{Y}$ & $\mathrm{Yb}$ & $\mathrm{Zn}$ & $\mathrm{Zr}$ \\
\hline PI01 & 6.666 & 2.166 & 390.7 & 1.122 & 0.83 & 14.38 & 0.419 & 5.998 & 222.8 & 2.834 & 28.35 & 2.794 & 153.2 & 144.2 \\
PI02 & 6.405 & 2.345 & 387.2 & 1.111 & 0.82 & 14.33 & 0.404 & 5.941 & 220.6 & 3.005 & 28.36 & 2.744 & 151 & 142.4 \\
PI03 & 6.051 & 2.431 & 362.9 & 1.122 & 0.764 & 14.22 & 0.389 & 5.553 & 213.1 & 2.647 & 26.85 & 2.678 & 143.6 & 141.7 \\
PI04 & 5.598 & 2.602 & 340 & 1.169 & 0.729 & 14.76 & 0.394 & 5.528 & 218.7 & 2.632 & 26.35 & 2.717 & 152.6 & 148.2 \\
PI05 & 6.791 & 2.768 & 411.7 & 1.17 & 0.868 & 15.01 & 0.431 & 6.415 & 237.5 & 3.456 & 29.93 & 2.932 & 165 & 148.2 \\
PI06 & 5.856 & 2.477 & 361.5 & 1.122 & 0.751 & 14.59 & 0.396 & 5.571 & 217.4 & 2.768 & 26.73 & 2.654 & 148.4 & 147 \\
PI07 & 5.84 & 2.332 & 345.2 & 1.123 & 0.732 & 14.37 & 0.379 & 5.539 & 215.6 & 2.849 & 26.13 & 2.606 & 144.5 & 145.6 \\
PI08 & 6.035 & 2.415 & 357.6 & 1.087 & 0.764 & 14.2 & 0.387 & 5.748 & 219.9 & 2.559 & 27.05 & 2.665 & 148.7 & 142 \\
PI09 & 6.261 & 2.579 & 362.4 & 1.139 & 0.776 & 14.69 & 0.404 & 5.826 & 221.8 & 2.792 & 27.53 & 2.706 & 157 & 147.6 \\
PI10 & 6.353 & 2.335 & 388 & 1.034 & 0.825 & 12.7 & 0.386 & 5.789 & 222.8 & 2.947 & 28.68 & 2.623 & 146 & 131.7 \\
PI11 & 5.759 & 2.412 & 344.6 & 1.18 & 0.763 & 14.91 & 0.398 & 5.76 & 219.2 & 2.952 & 26.81 & 2.717 & 142.9 & 149.5 \\
PI12 & 6.16 & 2.897 & 433.1 & 1.071 & 0.794 & 13.44 & 0.387 & 6.131 & 226.5 & 2.392 & 27.77 & 2.595 & 156.4 & 135 \\
PI14 & 5.97 & 2.207 & 414.7 & 1.073 & 0.773 & 13.5 & 0.377 & 5.84 & 216.3 & 1.531 & 27.54 & 2.598 & 155.4 & 135.6 \\
PI13 & 8.598 & 3.279 & 405.1 & 0.954 & 1.144 & 12.62 & 0.451 & 5.363 & 176.6 & 2.685 & 37.62 & 2.923 & 246.8 & 123.3 \\
PI15 & 1.205 & 3.582 & 0.964 & 0.085 & 51.33 & 0.413 & 6.003 & 12.27 & 37.63 & 43.48 & 22.1407 & 10.31 & 74.91 & 16.15 \\
PI16 & 1.582 & 3.895 & 0.945 & 0.082 & 38.8 & 0.426 & 5.522 & 12.94 & 33.91 & 41.94 & 27.8829 & 9.104 & 79.7 & 15.27 \\
PI17 & 1.381 & 3.695 & 0.98 & 0.091 & 40.63 & 0.429 & 5.878 & 12.94 & 34.7 & 41.66 & 26.3717 & 9.268 & 104.5 & 15.5 \\
Typical & & & & & & & & & & & & & \\
uncertainties & $5 \%$ & $15 \%$ & $5 \%$ & $10 \%$ & $5 \%$ & $5 \%$ & $10 \%$ & $15 \%$ & $5 \%$ & $15 \%$ & $5 \%$ & $5 \%$ & $10 \%$ & $8 \%$ \\
\hline
\end{tabular}

Table 4.5 Trace element data for the Raton Basin samples. Concentrations are given in $\mu \mathrm{g} / \mathrm{g}$. Typical uncertainties are based on repeat analyses of standards. 


\begin{tabular}{|c|c|c|c|c|c|c|c|c|c|c|c|}
\hline Sample & $\begin{array}{c}\mathrm{SiO}_{2} \\
\mathrm{Wt.} \%\end{array}$ & $\begin{array}{l}\mathrm{Al}_{2} \mathrm{O}_{3} \\
\text { Wt.\% }\end{array}$ & $\begin{array}{l}\mathrm{Fe}_{2} \mathrm{O}_{3} \\
\text { Wt.\% }\end{array}$ & $\begin{array}{l}\mathrm{MnO} \\
\mathrm{Wt} . \%\end{array}$ & $\begin{array}{l}\mathrm{MgO} \\
\text { Wt.\% }\end{array}$ & $\begin{array}{c}\mathrm{CaO} \\
\mathrm{Wt} . \%\end{array}$ & $\begin{array}{l}\mathrm{Na}_{2} \mathrm{O} \\
\mathrm{Wt} . \%\end{array}$ & $\begin{array}{l}\mathrm{K}_{2} \mathrm{O} \\
\mathrm{Wt} . \%\end{array}$ & $\begin{array}{l}\mathrm{TiO}_{2} \\
\text { Wt.\% }\end{array}$ & $\begin{array}{l}\mathrm{P}_{2} \mathrm{O}_{5} \\
\text { Wt. \% }\end{array}$ & $\begin{array}{c}\text { PF } \\
\text { Wt.\% }\end{array}$ \\
\hline PI01 & 59.79 & 17.54 & 5.61 & 0.04 & 3.20 & 6.90 & 2.13 & 2.90 & 0.71 & 0.21 & 1.52 \\
\hline PIO2 & 59.02 & 17.50 & 5.55 & 0.03 & 3.03 & 6.58 & 2.13 & 2.96 & 0.70 & 0.21 & 2.11 \\
\hline PI03 & 59.68 & 17.61 & 5.41 & 0.03 & 3.05 & 6.14 & 1.91 & 3.14 & 0.71 & 0.20 & 2.48 \\
\hline PI04 & 60.33 & 17.83 & 5.09 & 0.03 & 2.97 & 5.74 & 1.56 & 3.25 & 0.73 & 0.19 & 2.77 \\
\hline PI05 & 59.14 & 17.53 & 5.65 & 0.03 & 2.94 & 6.78 & 2.04 & 2.94 & 0.70 & 0.21 & 2.08 \\
\hline PI06 & 59.68 & 17.65 & 5.15 & 0.03 & 2.89 & 5.91 & 1.56 & 3.13 & 0.72 & 0.20 & 2.66 \\
\hline PI07 & 60.13 & 17.77 & 5.03 & 0.03 & 2.86 & 6.13 & 1.53 & 3.04 & 0.71 & 0.20 & 2.72 \\
\hline PI08 & 59.68 & 17.80 & 5.42 & 0.03 & 2.93 & 6.66 & 1.61 & 3.07 & 0.71 & 0.20 & 2.19 \\
\hline PI09 & 59.76 & 17.68 & 5.30 & 0.03 & 2.86 & 6.45 & 1.59 & 3.02 & 0.71 & 0.20 & 2.63 \\
\hline PI10 & 57.36 & 16.04 & 6.89 & 0.04 & 3.97 & 8.43 & 1.67 & 2.75 & 0.65 & 0.21 & 2.31 \\
\hline PI11 & 59.77 & 17.57 & 5.13 & 0.03 & 3.00 & 6.00 & 1.60 & 3.00 & 0.72 & 0.19 & 2.57 \\
\hline PI12 & 57.92 & 16.15 & 5.40 & 0.03 & 3.52 & 3.62 & 5.01 & 3.39 & 0.66 & 0.20 & 4.16 \\
\hline PI14 & 54.49 & 15.99 & 5.34 & 0.03 & 2.25 & 4.71 & 6.76 & 2.53 & 0.65 & 0.19 & 6.79 \\
\hline PI13 & 53.48 & 15.74 & 4.28 & 0.03 & 1.66 & 5.26 & 7.18 & 1.67 & 0.60 & 0.21 & 8.65 \\
\hline PI15 & 57.57 & 15.96 & 4.58 & 0.03 & 2.70 & 3.63 & 6.48 & 2.22 & 0.65 & 0.21 & 5.39 \\
\hline PI16 & 57.97 & 15.98 & 5.21 & 0.03 & 3.53 & 1.92 & 5.89 & 2.30 & 0.67 & 0.19 & 5.26 \\
\hline PI17 & 59.22 & 15.87 & 4.75 & 0.03 & 3.36 & 2.72 & 5.31 & 2.62 & 0.64 & 0.22 & 5.70 \\
\hline $\begin{array}{c}\text { Typical } \\
\text { uncertainties }\end{array}$ & $8 \%$ & $1 \%$ & $2 \%$ & $5 \%$ & $5 \%$ & $2 \%$ & $5 \%$ & $5 \%$ & $5 \%$ & $10 \%$ & \\
\hline
\end{tabular}

Table 4.6 Major element analysis of the Raton Basin samples (wt.\%). Typical uncertainties are provided by SARM and are based on repeat analyses of standards. "PF" represents the loss on ignition. 


\begin{tabular}{|l|c|c|}
\hline & $\mathbf{R}^{2}$, linear regression & $\mathbf{R}^{2}$, logarithmic regression \\
\hline Group A - Os concentration & 0.01 & 0.23 \\
\hline Group A $-{ }^{187} \mathbf{O s} /{ }^{188} \mathbf{O s}$ & 0.19 & 0.23 \\
\hline Group B - Os concentration & 0.21 & 0.33 \\
\hline Group B $-{ }^{187} \mathbf{O s} /{ }^{188} \mathbf{O s}$ & 0.64 & 0.67 \\
\hline
\end{tabular}

Table 4.7 Type 1 regression correlation coefficients versus distance from the contact of linear and logarithmic regressions for both groups not corrected for age. 


\begin{tabular}{|l|c|c|}
\hline & $\mathbf{R}^{2}$, linear regression & $\mathbf{R}^{2}$, logarithmic regression \\
\hline Group A - Os concentration & 0.01 & 0.24 \\
\hline Group A $-{ }^{187} \mathbf{O s} /{ }^{188} \mathbf{O s}$ & 0.16 & 0.18 \\
\hline Group B - Os concentration & 0.21 & 0.33 \\
\hline Group B $-{ }^{187} \mathbf{O s} /{ }^{188} \mathbf{O s}$ & 0.71 & 0.62 \\
\hline
\end{tabular}

Table 4.8 Age-corrected regression correlation coefficients versus distance from the contact of linear and logarithmic regressions for both groups, corrected to the time of the dike intrusion (24.16 $\pm 1.01 \mathrm{Ma}$; Scott et al., 1990). 

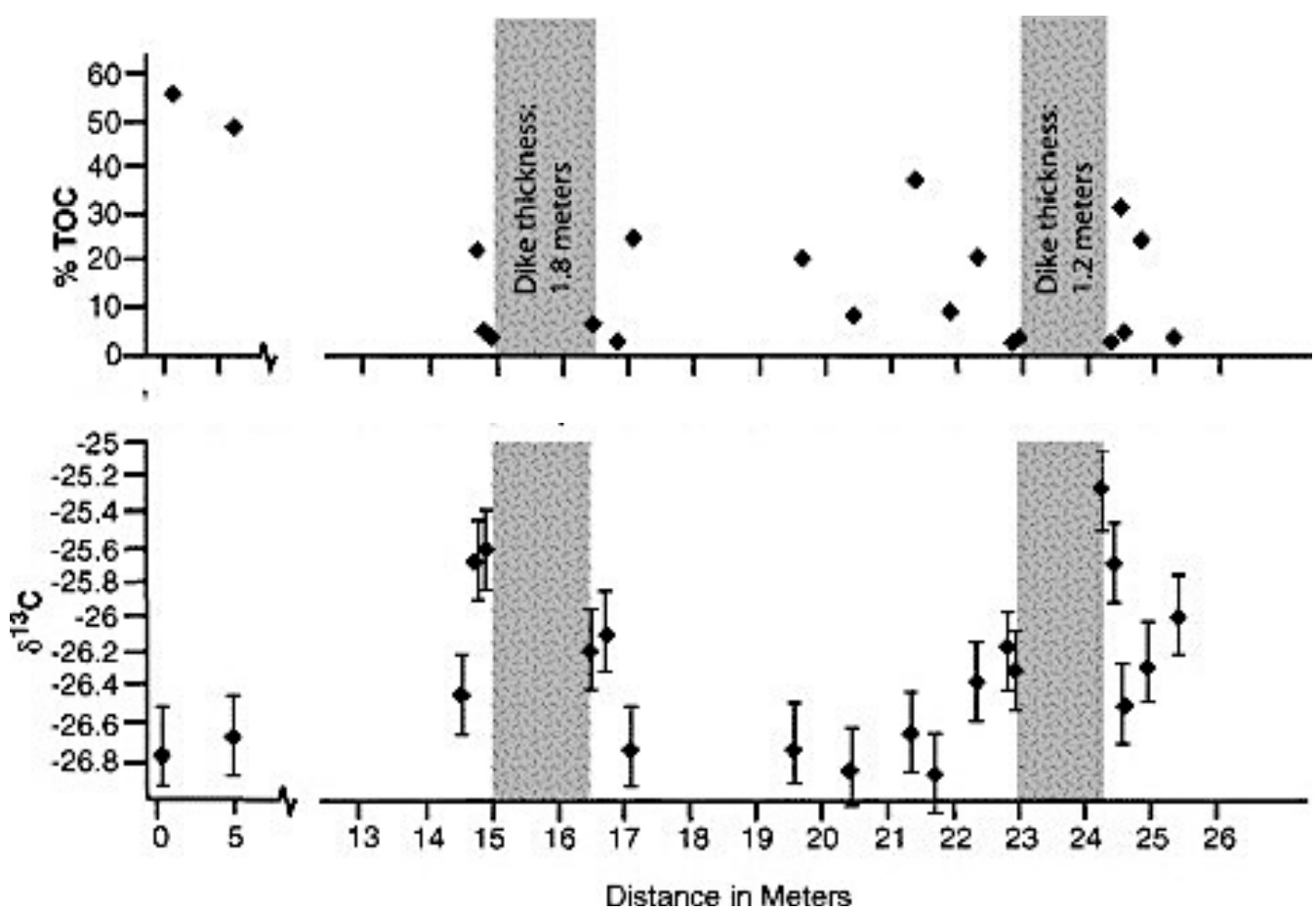

Figure 4.1 Total organic carbon (TOC, in weight $\%$ ) and bulk organic carbon $\delta^{13} \mathrm{C}$ of coal seams metamorphosed by dike intrusions (gray bars) in the Raton Basin, New Mexico. Low TOC concentrations and elevated $\delta^{13} \mathrm{C}$ of organic carbon are suggestive of significant loss of isotopically light carbon near the contacts (from Cooper et al., 2007). 


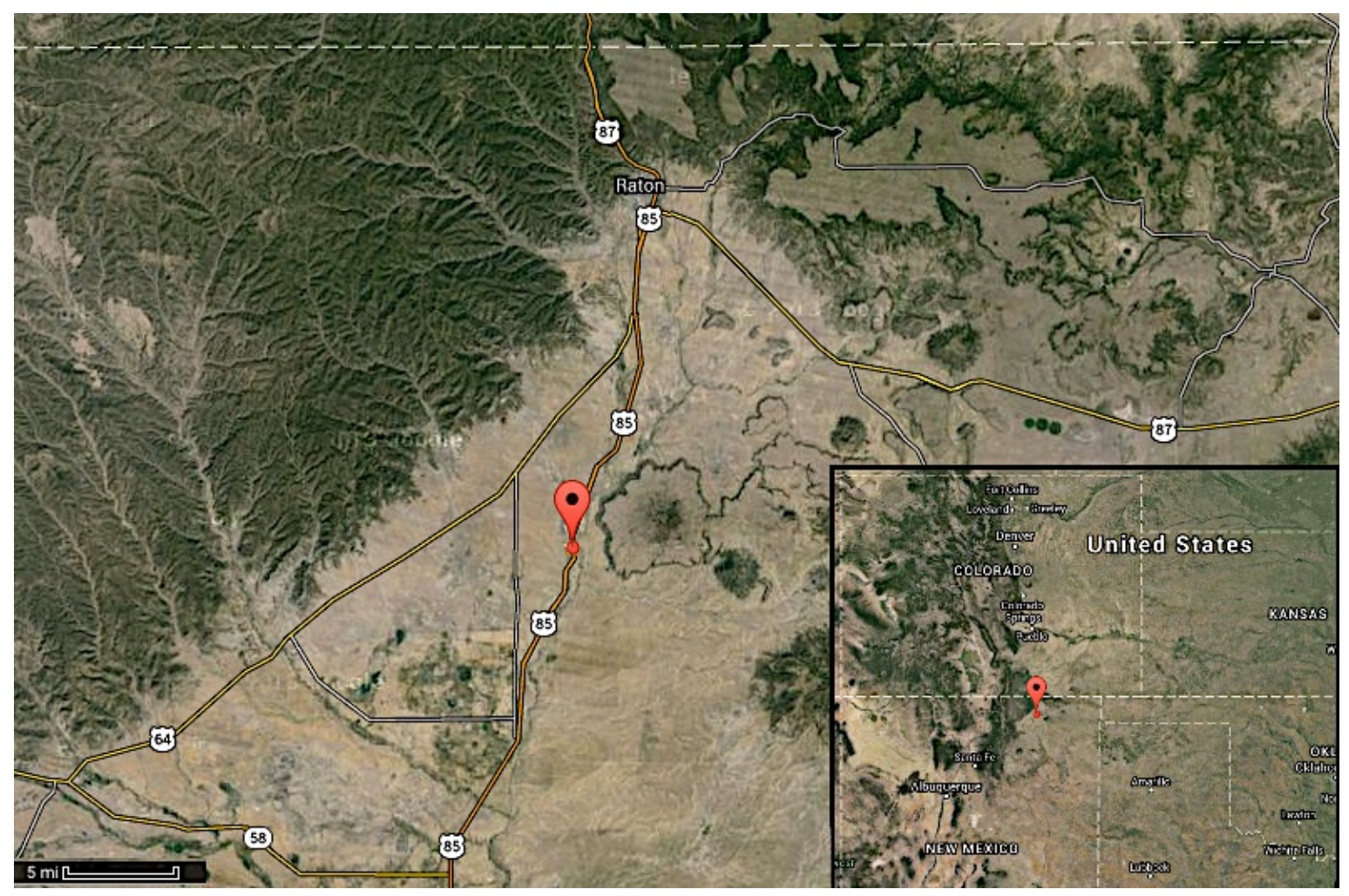

Figure 4.2 Google Maps image depicting the location of the Tinaja outcrop in northern New Mexico. 


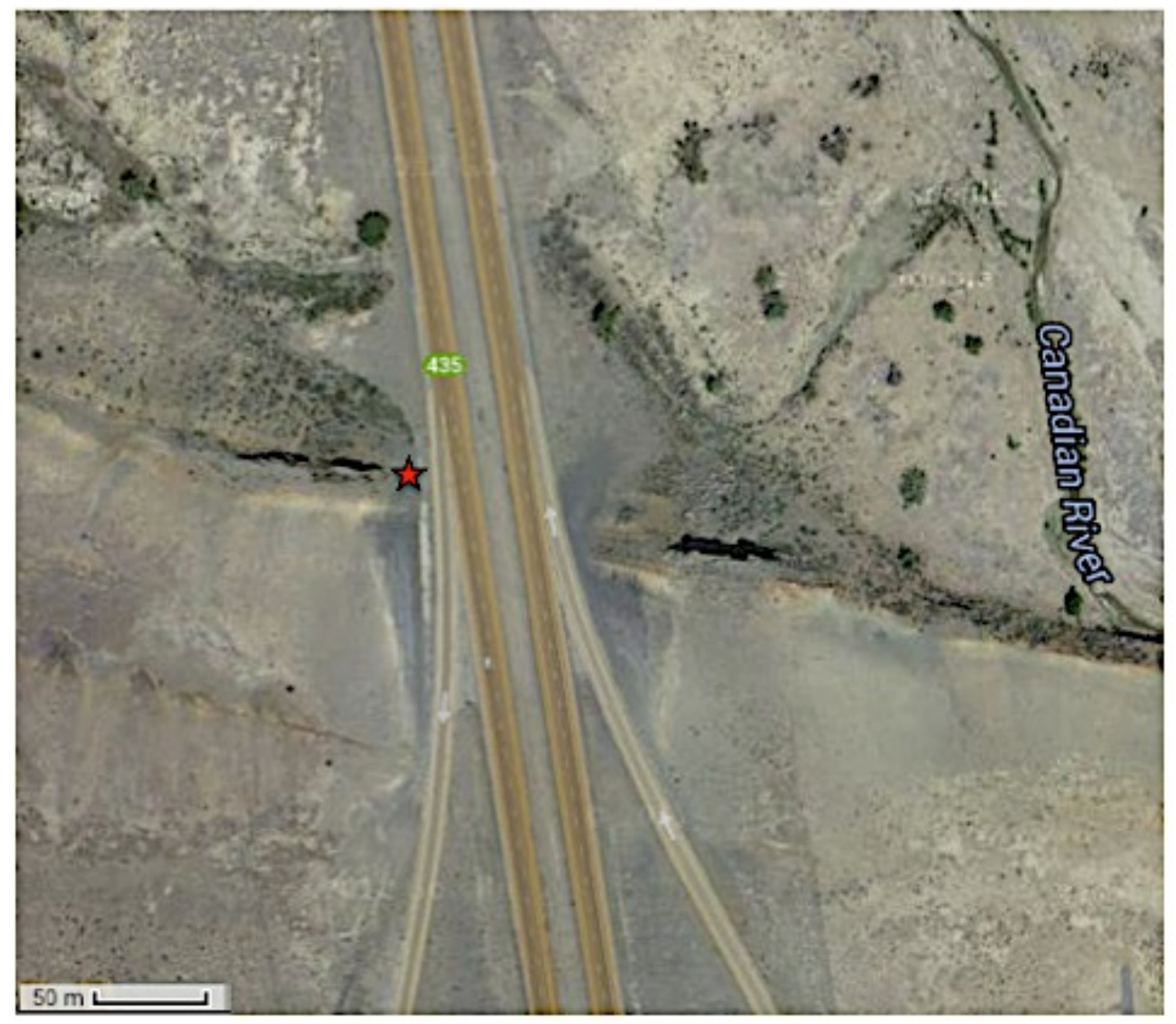

Figure 4.3 Close-up aerial Google maps view of the Tinaja outcrop (marked with a red star) on the western side of the Interstate Highway 25 at exit 435. The Eagle Rock dike forms an EastSoutheast trending ridge with the resistant hornfels on either side of the dike. 


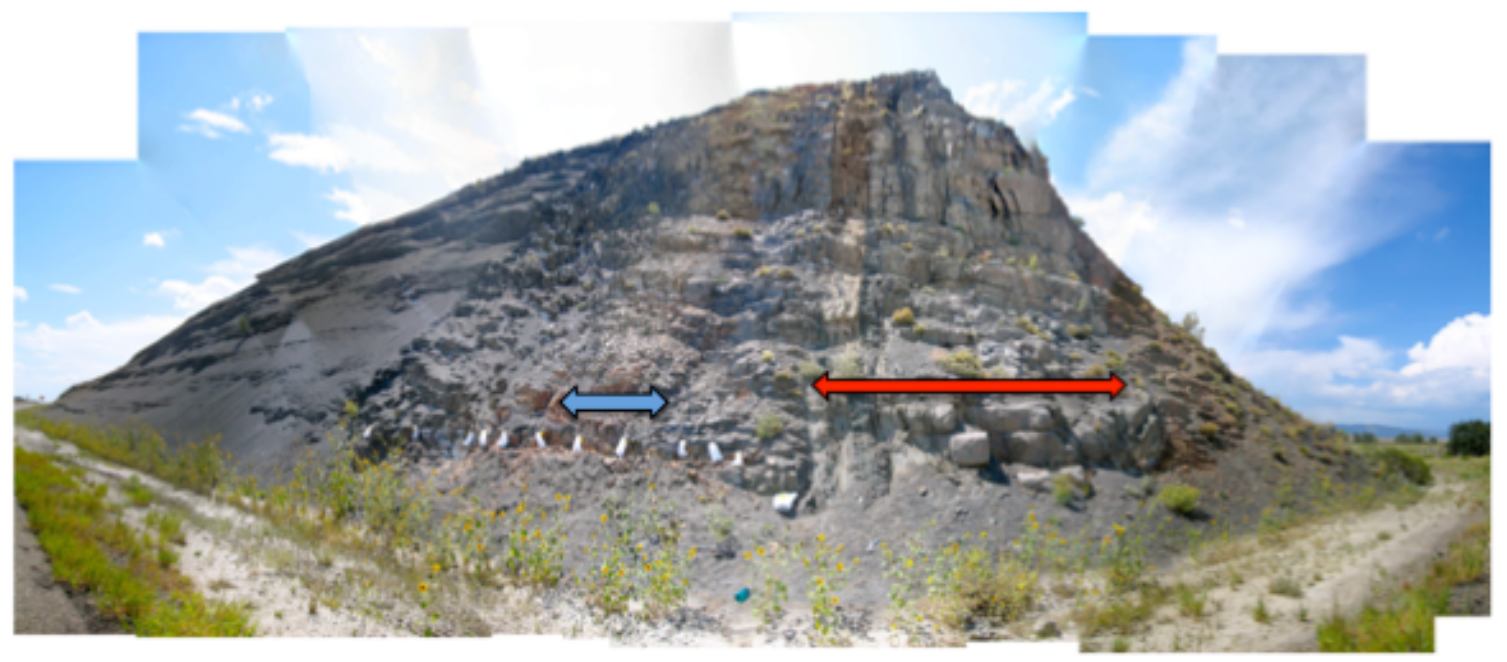

Figure 4.4 Tinaja outcrop looking South. The Interstate 25 highway is to the left. The width of the dike $(8.8 \mathrm{~m})$ is marked by the red arrow, and the band of highly weathered samples $(\sim 3 \mathrm{~m}$ wide) is represented by the blue arrow. White sample bags indicate the locations of most of the samples. Not all sample bags are shown. 


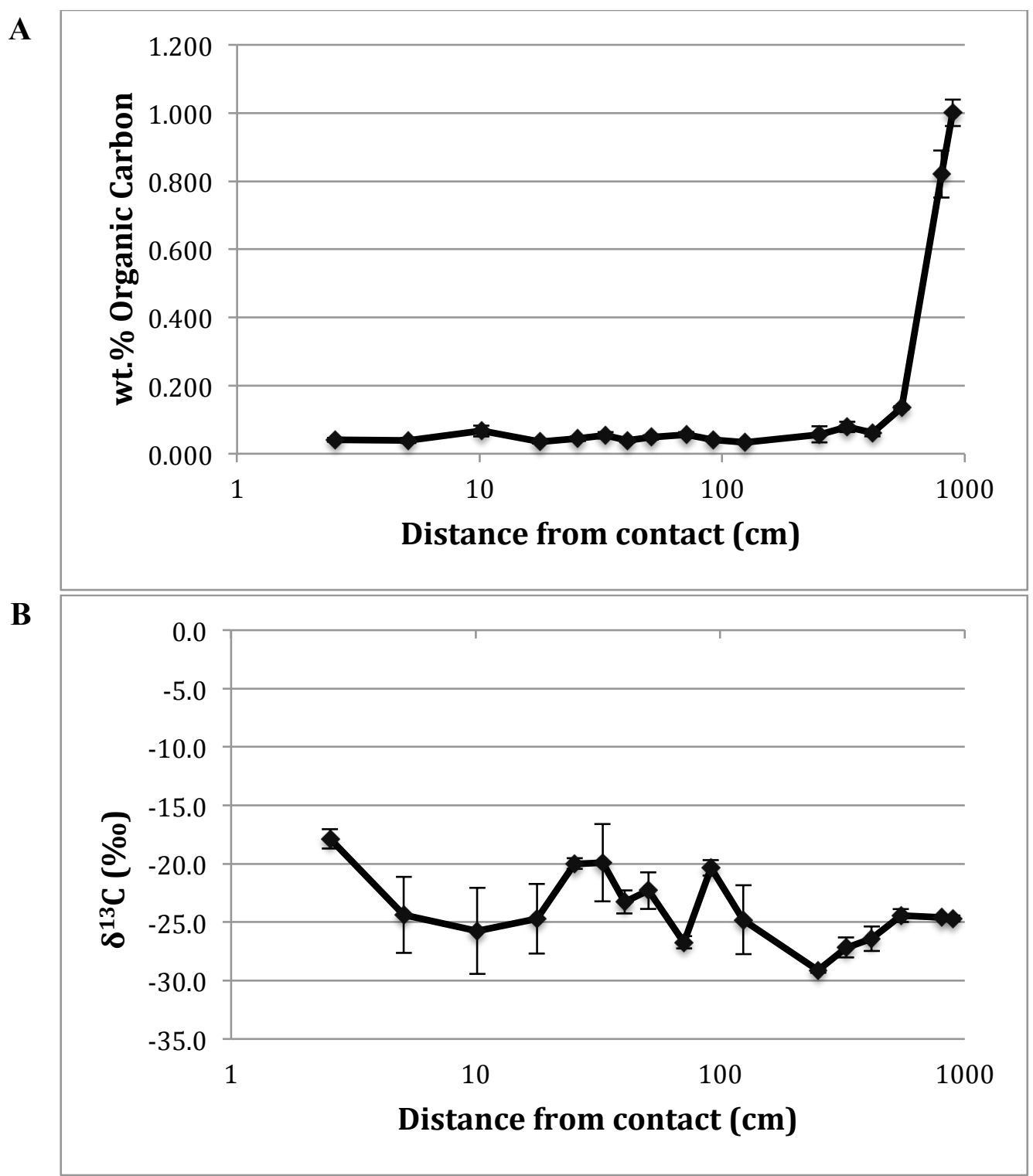

Figure 4.5 TOC concentration (A) and $\delta^{13} \mathrm{C}$ of TOC (B) for the Raton Basin samples. Note the depletion in organic carbon close to the intrusive contact. A logarithmic scale is chosen for distance from contact to show differences in samples taken close to the contact. Error bars represent 1 s.d. 


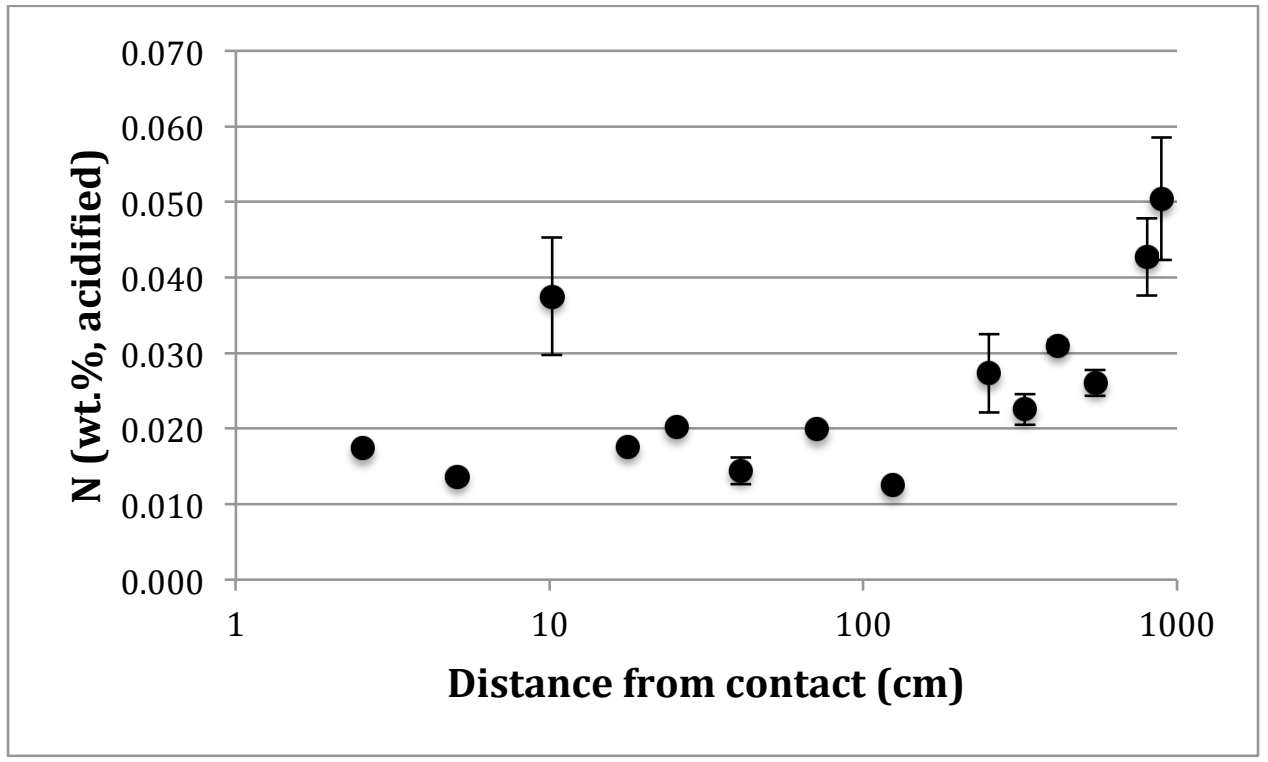

Figure 4.6 Total N concentrations of the Raton Basin samples. Due to low concentrations, no data is available for three of the samples. Uncertainties are based on one standard deviation, but uncertainty estimates are not available for four of the samples that were analyzed only once. 
A



B



C

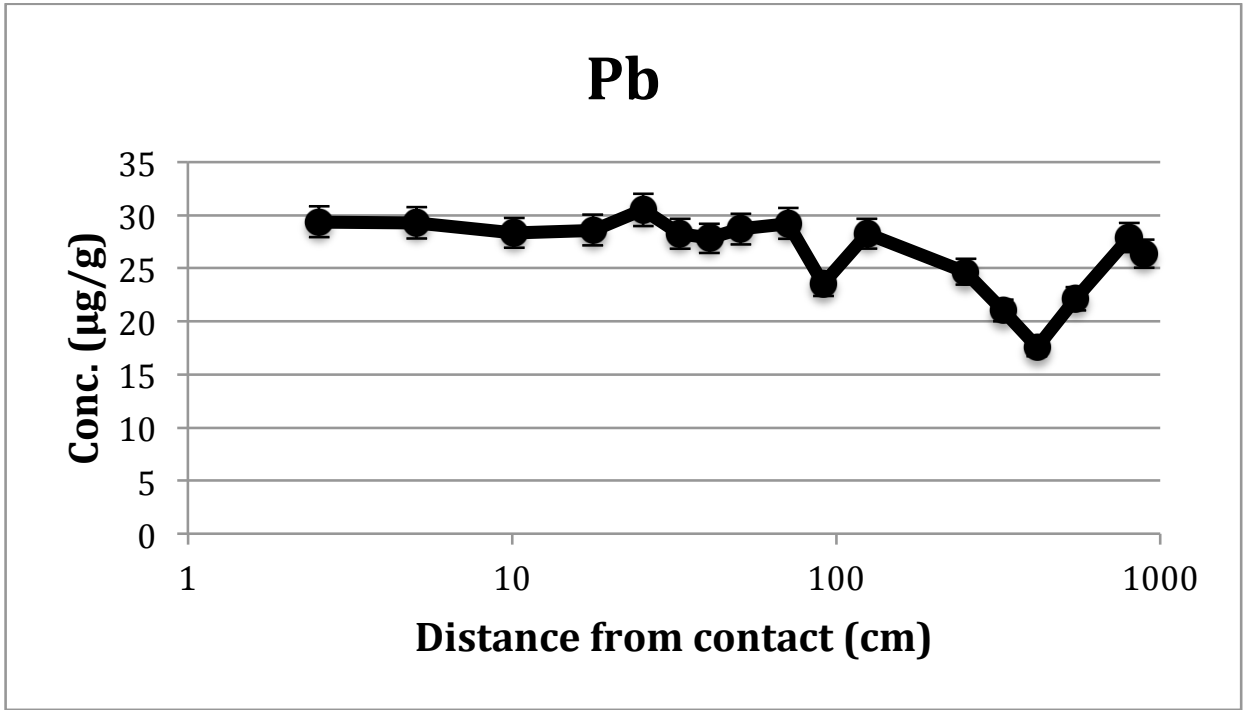


Figure 4.7 Bulk sediment $\mathrm{U}(\mathrm{A})$, Th (B), and $\mathrm{Pb}(\mathrm{C})$ concentrations (conc.) measured in the Raton Basin samples. Uncertainties are based on maximum estimates from repeat samples that SARM provides, and vary according to concentrations. 


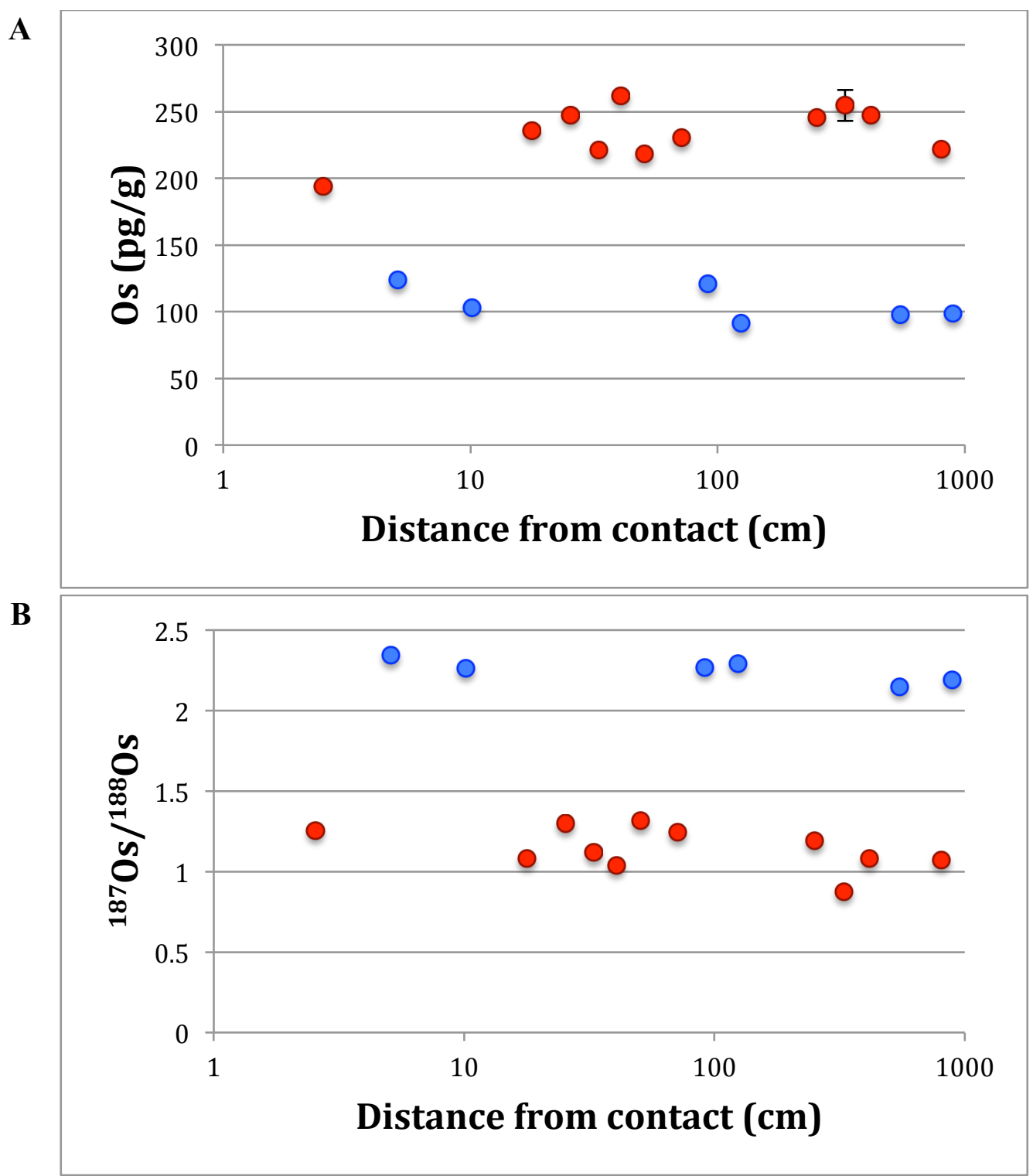

Figure 4.8 Osmium concentrations (A) and ${ }^{187} \mathrm{Os} /{ }^{188}$ Os (B) for all Raton Basin samples, not corrected for age. Group A data points are shown in red, while group B are depicted in blue. 




Figure 4.9 Rhenium concentrations of the Pierre Shale samples. The gray band indicates the weathered band in the outcrop. Uncertainties are smaller than the size of the markers. 



Figure 4.10 Age-corrected Os concentrations (A) and isotopic compositions (B) for the Raton Basin samples. Group A data points are depicted as red squares while group B are shown in blue. Circles represent the present-day measured values, squares the age-corrected values to the time of the intrusion, and triangles indicate values age-corrected to the approximate time of deposition ( 70 Ma; Johnson and Finn, 2001). 


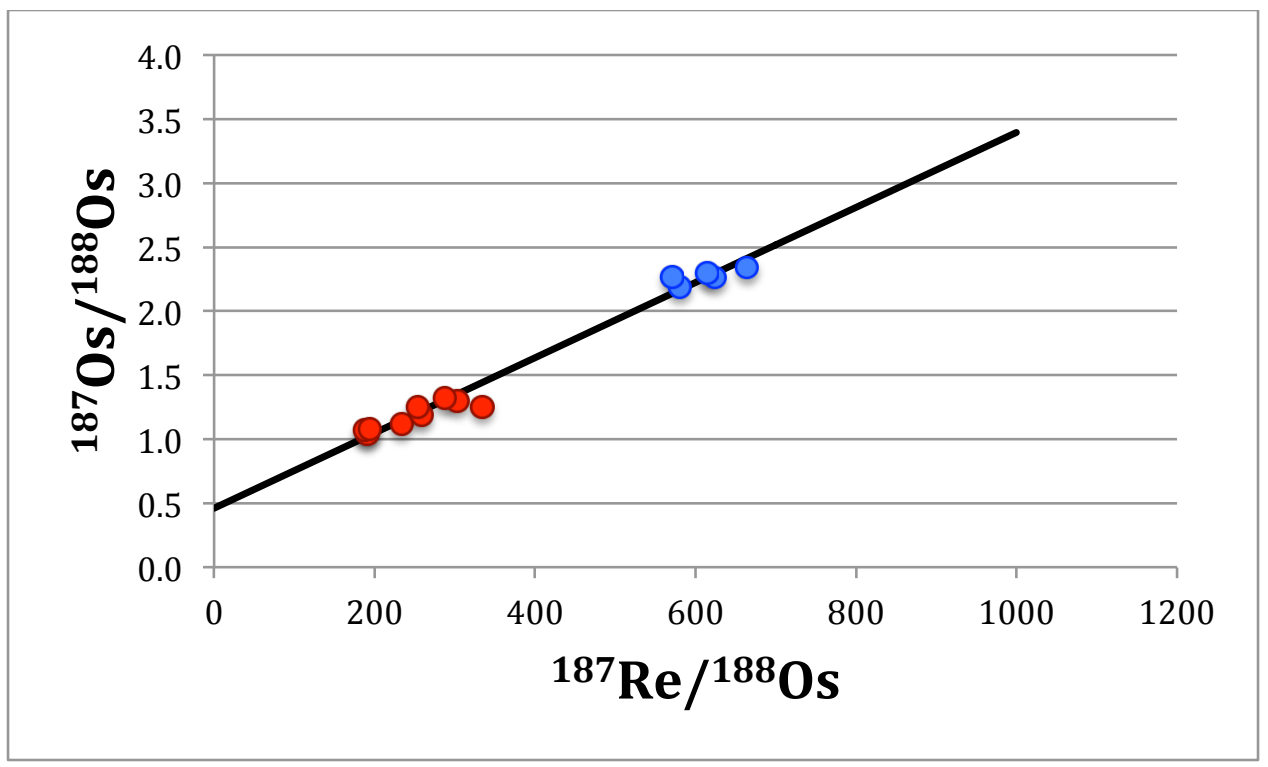

Figure 4.11 Isochron diagram for group A (red) and group B (blue) samples from the Raton Basin. The slope of the reference line corresponds to an age of the samples of $179 \pm 7 \mathrm{Myr}$, approximately 2.5 times the age of the Pierre Shale, indicating that the linear correlation likely reflects two-component mixing. 


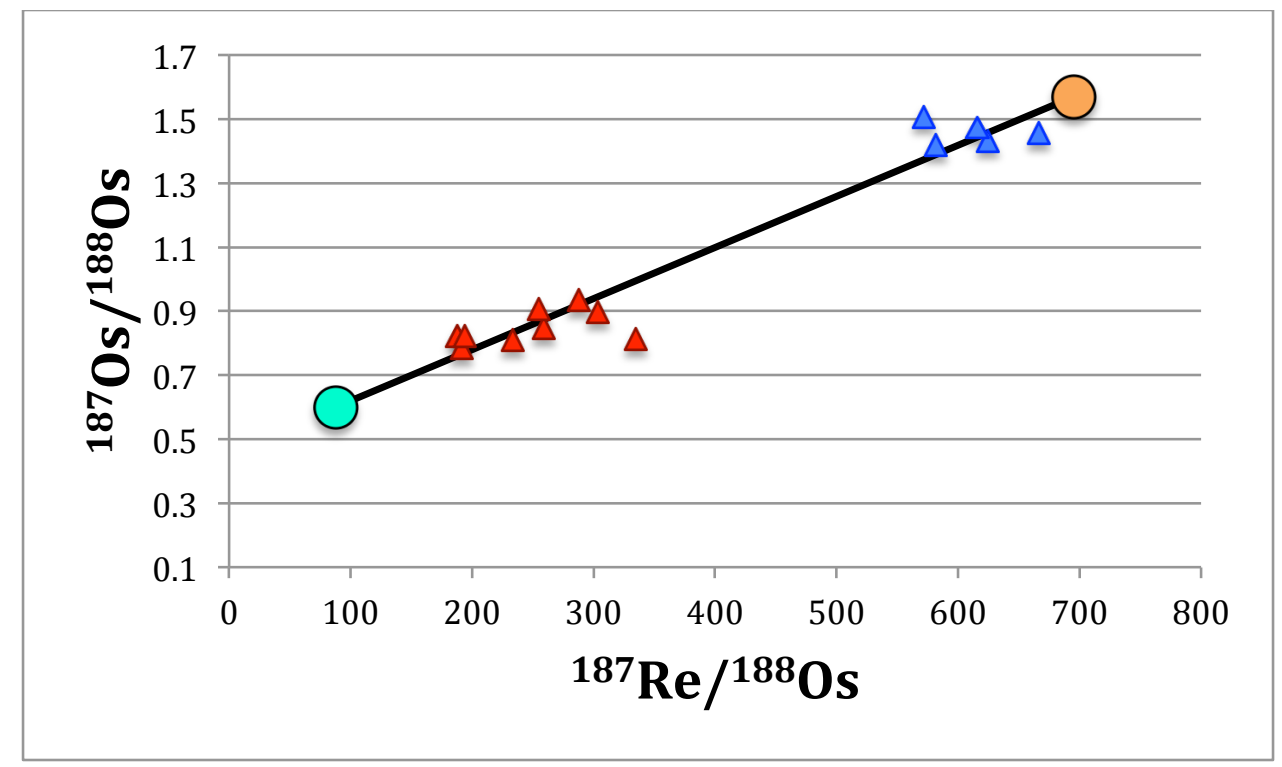

Figure 4.12 Two-component mixing diagram for the Tinaja outcrop bulk sediments at the approximate time of deposition $(70 \mathrm{Ma})$. Group A data points are again shown in red while group B are shown in blue. The linear mixing line is shown in black. The black line represents the mixing line with the two large circles representing the composition of two potential endmembers. The aqua circle represents the hydrogenous end-member, i.e. seawater ${ }^{187} \mathrm{Os} /{ }^{188} \mathrm{Os}$ at the time of deposition, while the orange circle represents the detrital end-member. 


\subsection{References}

Bostick, N.H., Pawlewicz, M.J., 1984. Paleotemperatures based on vitrinite reflectance of shales and limestones in igneous dike aureoles in the Upper Cretaceous Pierre Shale, Walsenburg, Colorado. In: Woodward, J., Meissner, F.F., Clayton, J.L. (Eds.), Hydrocarbon Source Rocks of the Greater Rocky Mountain Region, pp. 387-392.

Carpentier, M., Weis, D., Chauvel, C., 2013. Large U loss during weathering of upper continental crust: the sedimentary record. Chemical Geology 340, 91-104.

Cohen, A.S., Coe, A.L., Bartlett, J.M., Hawkesworth, C.J. 1999. Precise Re-Os ages of organicrich mudrocks and Os isotope composition of Jurassic seawater. Earth and Planetary Science Letters 167, 159-173.

Colodner, D., Sachs, J., Ravizza, G., Turekian, K.K., Edmond, J., Boyle, E., 1993. The geochemical cycle of rhenium: a reconnaissance. Earth and Planetary Science Letters 117, 205221.

Cooper JR (2006). Igneous intrusion and thermal evolution in the Raton Basin, CO-NM: Contact metamorphism and coal-bed methane generation. MS thesis, University of MissouriColumbia, 249 p.

Cooper JR, JC Crelling, SM Rimmer, AG Whittington (2007). Coal metamorphism by igneous intrusion in the Raton Basin, CO and NM: Implications for generation of volatiles. International Journal of Coal Geology 71, 15-27.

Crelling, J.C., Dutcher, R.R., 1968. Petrologic study of a thermally altered coal from the Purgatoire river valley of Colorado. Geological Society of America Bulletin 79, 1375-1386.

Crusius, J., Thomson, J., 2000. Comparative behavior of authigenic Re, U, and Mo during reoxidation and subsequent long-term burial in marine sediments. Geochimica et Cosmochimica Acta 64, 2233-2242.

Dean, W.E., Arthur, M.A., 1989. Iron-sulfur-carbon relationships in organic-carbon-rich sequences I: Cretaceous Western Interior Seaway. American Journal of Science 289, 708-743.

Du Laing, G., De Vos, R., Vandecasteele, B., Lesage, E., Tack, F.M.G., Verloo, M.G., 2008. Effect of salinity on heavy metal mobility and availability in intertidal sediments of the Scheldt estuary. Estuarine, Castal and Shelf Science 77(4), 589-602.

Esser, B.K., Turekian, K.K., 1993. The osmium isotopic composition of the continental crust. Geochimica et Cosmochimica Acta 57, 3093-3104.

Flores, R.M., Bader, L.R., 1999. A summary of Tertiary coal resources of the Raton Basin, Colorado and New Mexico. In USGS Professional Paper 1625-A. 
Galushkin, Y.I., 1997. Thermal effects of igneous intrusions on maturity of organic matter: a possible mechanism of intrusion. Organic Geochemistry 26, 645-658.

Goldschmidt, V.M., 1922. Der Stoffwechsel der Erde. Skrifter utgit av Videnskapsselskapets I Kristiana. I, Matematisk-Naturvidenskabelig Klasse 11, 3-25.

Jaffe, L.A., Peucker-Ehrenbrink, B., Petsch, S.T., 2002. Mobility of rhenium, platinum group elements and organic carbon during black shale weathering. Earth and Planetary Science Letters 198, 339-353.

Johnson, R.C., Finn, T.M., 2001. Potential for a Basin-Centered Gas Accumulation in the Raton Basin, New Mexico. U.S. Geological Survey Bulletin 2184-B, 1-14.

Kennedy, M.J., Pevear, D.R., Hill, R.J., 2002. Mineral surface control of organic carbon in black shale. Science 295, 657-660.

Lee, P.M., 2005. Spatial, temporal and petrogenic relationships of basaltic and lamprophyric dikes and sills of the Raton Basin, southern Colorado and northern New Mexico. University of Missouri-Columbia, Masters Thesis, 160 p.

Levasseur, S., Rachold, V., Brick, J.L., Allegre, C.J., 2000. Osmium behaviour in estuaries: the Lena River example. Earth and Planetary Science Letters 177, 227-235.

McLennan, S.M., 2001. Relationships between the trace element composition of sedimentary rocks and upper continental crust. Geochemistry, Geophysics, Geosystems 2, paper number 2000GC00109.

Miggins D.P., 2002. Chronological, geochemical and isotopic framework of igneous rocks within the Raton Basin and adjacent Rio Grande Rift, South-Central Colorado and Northern New Mexico. University of Colorado, Boulder, Masters Thesis, 417 p.

Miller, C.A., Peucker-Ehrenbrink, B., Walker, B.D., Marcantonio, F., 2011. Re-assessing the surface cycling of molybdenum and rhenium. Geochimica et Cosmochimica Acta 75, 7146-7179.

Morford, J.L., Emerson, S., 1999. The geochemistry of redox sensitive trace metals in sediments. Geochimica et Cosmochimica Acta 63, 1735-1750.

Morgan JW, DW Golightly, AF Dorrzapf (1991). Methods for the separation of rhenium, osmium, and molybdenum applicable to isotope geochemistry. Talanta 38, 259-265.

Noddack, I., Noddack, W., 1931. Die Geochemie des Rheniums. Zeitschrift für Physikalische Chemie 154A, 207-244.

Nozaki, T., Suzuki, K., Ravizza, G., Kimura, J.-L., Chang, Q., 2012. A method for rapid determination of Re and Os compositions using ID-MC-ICP-MS combined with the sparging method. Geostandards and Geoanalytical Research 36, 131-148. 
Penn, B.S., 1994. An investigation of the temporal and geochemical characteristics, and the petrogenetic origins of the Spanish Peaks intrusive rocks of south-central Colorado. Colorado School of Mines, Ph.D. Thesis, 198 p.

Peucker-Ehrenbrink, B., Jahn, B.M., 2001. Rhenium-osmium isotope systematics and platinum group element systematics: Loess and the upper continental crust. Geochemisty, Geophysics, Geosystems 2, DOI: 10.1029/2001GC000172.

Peucker-Ehrenbrink, B., Ravizza, G., 2000. The marine osmium isotope record. Terra Nova 5, 12, 205-219.

Peucker-Ehrenbrink, B., Ravizza, G., 2012. Osmium Isotope Stratigraphy. In: The Geologic Time Scale 2012. (F.M. Gradstein, J.G. Ogg, M.D. Schmitz, G.M. Ogg, Eds.), Elsevier, Oxford, $\mathrm{UK}, 23 \mathrm{pp}$.

Peters, K.E., Cassa, M.R., 1994. Applied source rock geochemistry, in Magoon L.B., and Doweds, W.G., The petroleum system - from source to trap: American Association of Patroleum Geologists Memoir 60, 93-120.

Peterson, M.D., 1983. The use of the "Immobile" elements $\mathrm{Zr}$ and Ti in lithogeochemical exploration for massive sulphide deposits in the Precambrian Pecos Greenstone Belt of northern New Mexico. Journal of Geochemical Exploration 19, 615-617.

Pillmore, C.L., Tschudy, R.H., Orth, C.J., Gilmore, J.S., Knight, J.D., 1984. Geologic framework of nonmarine Cretaceous-Tertiary boundary sites, Raton Basin, New Mexico and Colorado. Science 223, 1180-1183.

Ravizza G, D Pyle (1997). PGE and Os isotopic analyses of single sample aliquots with NiS fire assay preconcentration. Chemical Geology 141, 251-268.

Ravizza, G., Turekian, K.K., 1989. Application of the ${ }^{187}$ Re- ${ }^{187}$ Os system to black shale geochronometry. Geochimica et Cosmochimica Acta 53, 3257-3262.

Ravizza, G., Turekian, K.K., Hay, B.J., 1991. The geochemistry of rhenium and osmium in recent sediments from Black Sea. Geochimica et Cosmochimica Acta 55, 3741-3752.

Savard, D., Bames, S.-J., Meisel, T., 2010. Comparison between nickel-sulfur fire assay Te Coprecipitation and isotope dilution with high-pressure asher acid digestion for the determination of platinum-group elements, rhenium and gold. Geostandards and Geoanalytical Research 34, 281-291.

Schmidt, G., Palme, H., Kratz, K.L., 1997. Fractionation of highly siderophile elements in the Earth's upper continental crust, Yearbook Institute for Nuclear Chemistry, Mainz, Germany, p.15. 
Scott, G.R., 1986. Geologic and structure contour map of the Springer 30'x 60' quadrangle, Colfax, Harding, Mora, and Union Counties, New Mexico. U.S. Geological Survey

Miscellaneous Investigations Series Map, I-1705, scale 1:100,000.

Scott, G.R., Wilcox, R.E., Mehnert, H.H., 1990. Geology of volcanic and subvolcanic rocks of the Raton-Springer area, Colfax and Union counties, New Mexico. U.S. Geological Survey Professional Paper 1507, 58 p.

Selby, D., Creaser, R.A., 2003. Re-Os geochronology of organic-rich sediments: an evaluation of organic matter analysis. Chemical Geology 200, 225-240.

Sen, I.S., Peucker-Ehrenbrink, B., 2014. Determination of osmium concentrations and ${ }^{187} \mathrm{Os} /{ }^{188} \mathrm{Os}$ of crude oils and source rocks by coupling high-pressure, high-temperature digestion with sparging $\mathrm{OsO}_{4}$ into a Multicollector Inductively Coupled Plasma Mass Spectrometer. Analytical Chemistry 86, 2982-2988.

Sharp, R.P., 1948. Early Tertiary fanglomerate, Big Horn Mountains, Wyoming. Journal of Geology 56, 1-15.

Smoliar, M.I., Walker, R.J., Morgan, J.W., 1996. Re-Os ages of group IIA, IIIA IVA, and IVB iron meteorites. Science 271, 1099-1102.

Stormer, J.C., 1972. Mineralogy and Petrology of the Raton-Clayton Volcanic Field, Northeastern New Mexico. Geological Society of America Bulletin 83, 3299-3322.

Sun, W.D., Bennett, V.C., Eggins, S.M., Kamenetsky, V.S., Arculus, R.J., 2003. Enhanced mantle-to-crust rhenium transfer in undegassed arc magmas. Nature 422, 294-297.

Suzuki, K., Qi-Lu, Shimizu, H., Masuda A., 1993. Reliable Re-Os age for molybdenite. Geochimica et Cosmochimica Acta 57, 1625-1628.

Svensen, H,, Planke, S., Melthe-Sørenssen, A., Jamtveit, B., Myklebust, R., Rasmussen Eidem, T., Rey, S.S., 2004. Release of methane from a volcanic basin as a mechanism for initial Eocene global warming. Nature 429, 542-545.

Taylor, S.R., McLennan, S.M., 1985. The Continental Crust: Its Composition and Evolution. Blackwell Science, Malden, Mass. 312 pp.

Whiteside, J.H., Olsen, P.E., Eglinton, T.I., Cornet, B., McDonald, N.G., Huber, P., 2011. Pangean great lake paleoecology on the cusp of the end-Triassic extinction. Palaeogeography, Palaeoclimatology, Palaeoecology 301, 1-17.

Wieczorek, R., Fantle, M.S., Kump, L.R., Ravizza, G., 2013. Geochemical evidence for volcanic activity prior to and enhanced terrestrial weathering during the Paleocene Eocene Thermal Maximum. Geochimica et Cosmochimica Acta 119, 391-410. 


\section{CHAPTER 5.}

\section{A potential modern submarine analog for the North Atlantic Magmatic Province - the Guaymas Basin, Mexico}

\subsection{Abstract}

The Guaymas Basin in the Gulf of California is a modern example of a young rift zone where doloritic sills and dikes intrude organic-rich sediments. This is a potential modern analog of the North Atlantic Magmatic Province (NAMP), which may have triggered the PaleoceneEocene thermal maximum when a swarm of intrusions caused large-scale contact metamorphism of organic-rich sediments, possibly leading to the volatilization of large quantities of thermally derived methane. I use this setting to test this hypothesis, proposed by Svensen et al. (2004), by examining the mobilizations of osmium and lead relative to organic carbon near magmatic contacts. These elements, which have isotopes derived from redox sensitive elements enriched in suboxic and reducing conditions, carry unique isotopic signatures distinct from average continental crust. I find that large portions of the osmium are released alongside organic carbon. The ratio of mobilized Os to TOC leads to estimates of between $47 \%$ and $60 \%$ of the carbon released at the PETM that may have resulted from magmatic intrusion into organic-rich sedimentary strata. Lead is not similarly mobilized during contact metamorphism and is therefore deemed not a usable proxy to evaluate the extent of the carbon release from the NAMP during the PETM. 


\subsection{Introduction}

One proposed mechanism for the carbon release at the Paleocene-Eocene Thermal Maximum (PETM) involves thermal alteration of sediments rich in organic matter in the North Atlantic Magmatic Province (NAMP; Svensen et al., 2004). The organic carbon is thermally altered to methane and escapes via hydrothermal vent complexes to the overlying oceanatmosphere system. Isotopes of rhenium and uranium, which are both enriched in suboxic to reducing conditions under which organic-rich sediments are formed (e.g. Cohen et al., 1999; Colodner et al., 1993; Ravizza and Turekian, 1989; Ravizza et al., 1991; Selby and Creaser, 2003), decay to isotopes of osmium (Os) and lead $(\mathrm{Pb})$, respectively, causing these elements to develop unique isotopic signatures. If released along with organic carbon, they may help constrain the relative amount of sediment metamorphosed by the magmatic intrusions in the NAMP.

Potential analogs of these metamorphic processes may be used to determine changes in the $\mathrm{Os}, \mathrm{Pb}$, and TOC concentrations during contact metamorphism. Submarine intrusions into organic-rich sediments may differ significantly from the terrestrial analog examined in Chapter 4 due to convective flow of saline porewater through the sediments, which may help mobilize osmium and/or lead during contact metamorphism. In this chapter, I examine a potential submarine analog for the NAMP in a young continental rift zone to determine how $\mathrm{Os}, \mathrm{Pb}$, and organic carbon behave relative to each other in metamorphic aureoles caused by magmatic intrusions into organic-rich sediments.

The Gulf of California, which separates the Baja California peninsula from the mainland of Mexico, is an active spreading center, which formed during continental rifting beginning 12$15 \mathrm{Ma}$ (Stock and Lee, 1994). The Guaymas Basin (Figure 5.1), which is characterized by two 
rifts separated by a transform fault zone, is actively spreading. DSDP Leg 64 Site 477 is located in the southern area of the rift zone (Curray et al., 1982). Here, continental rifting causes doloritic sill and dike intrusions into unconsolidated organic-rich sediments, and the subsequent thermal alteration of these sediments causes release of carbon primarily as methane and $\mathrm{CO}_{2}$ (Gieskes et al., 1982; Kastner et al., 1982; Galimov and Simoneit, 1982; Seewald et al., 1990). DSDP Site 477 was chosen as an ideal location to isolate the effects of thermal alteration on the sediments due to the abundance of evidence indicating metamorphic alteration of organic matter within the sediments near the upper sill intrusion (Whelan and Hunt, 1982; Galimov and Simoneit, 1982; Simoneit and Galimov, 1984; Simoneit et al., 1986).

DSDP Site 477 contains multiple layers of doloritic sills (Figure 5.2). The shallowest sill, which is $47.5 \mathrm{~m}$ thick, acts as a lid on the deeper hydrothermal circulation. I focus on the sediment profile overlying the top sill as it is less likely to have been affected by the multiple deeper intrusions, and is also separated from deeper hydrothermal convective processes making it less likely to have been affected by regional hydrothermal circulation. The sediments in this profile consist of diatomaceous oozes and turbidites of late Pleistocene and younger ages (Curray et al., 1982).

Previous studies have investigated the mobility of metals in hot fluids at highly sedimented hydrothermal vent complexes such as the Guaymas Basin (Cruse and Seewald, 2001). The organic matter in the sediments pore waters percolate through can have significant impacts on metal solubility and ore formation (Disnar and Sureau, 1990). The generation of $\mathrm{CO}_{2}$ from oxidation of organic matter and release of $\mathrm{Ca}$ from albitization causes precipitation of carbonates and subsequent increase in acidity (Cruse and Seewald, 2001). This increases the mobility of transition metals such as $\mathrm{Fe}, \mathrm{Mn}$, and $\mathrm{Zn}$. However, the role of temperature was found to be 
critically important in highly-sedimented complexes, as the layers of sediment act as a thermal buffer, cooling the fluids prior to contact with overlying seawater and thereby decreasing mobility of metals.

\subsection{Methods}

\subsubsection{Sample preparation}

Samples were collected from the IODP Gulf Coast Repository on December 10, 2014. Nineteen sediment samples, as well as two samples of the intrusive sill, were recovered from depths ranging from 10 to 80 meters below sea floor (mbsf). Sampling density was highest closest to the sill contact (58 mbsf), but I was unable to sample all the way to the sill contact due to incomplete core recovery. Samples were removed from the cores with $5 \mathrm{~cm}^{3}$ plastic plugs, then placed in plastic bags and sealed for transport. Sill samples were cut from the recovered core using a rock saw and sealed in the same manner. At WHOI, the sample bags were opened, placed in glass dishes and samples were dried in an oven at $105^{\circ} \mathrm{C}$ overnight to remove any remaining pore fluid. A few grams of the dried samples were crushed inside the plastic bags, then ground using an agate mortar and pestle, and finally transferred to clean plastic vials for storage. The mortar and pestle were cleaned between samples by grinding clean quartz sand, which was discarded after each use.

\subsubsection{Organic carbon analysis}

Splits of each sample were sent to WHOI's Organic Geochemistry Facility for analysis of the total organic carbon (TOC) and total nitrogen concentrations as well as $\delta^{13} \mathrm{C}$ of total organic carbon, following the same procedure as outlined in chapter 4 . Ten sediment samples, as well as the two sill samples, were selected based on their TOC content for further analysis of $\mathrm{Os}$ and $\mathrm{Pb}$. 


\subsubsection{Osmium isotope analysis}

Osmium isotope and concentration analyses were performed on the samples following the procedure laid out in chapter 4. $100 \mathrm{mg}$ of sample was spiked with a ${ }^{190}$ Os tracer and digested in a High Pressure Asher (HPA). The decanted solution was then sparged into the ThermoElectron NEPTUNE Multi-collector Inductively Coupled Plasma Mass Spectrometer (MC-ICPMS). Procedural blanks accounted for less than 3\% of the total sample Os.

\subsubsection{Lead concentrations}

Lead concentrations were determined by isotope dilution following the procedure

outlined in chapter 3. Briefly, approximately $100 \mathrm{mg}$ of sample was spiked with a ${ }^{208} \mathrm{~Pb}$ tracer, and then dissolved. The $\mathrm{Pb}$ was extracted and purified by passing the sample through columns with $1 \mathrm{ml} \mathrm{AG} \mathrm{1x8} \mathrm{(100-200} \mathrm{mesh,} \mathrm{Bio-Rad)} \mathrm{resin,} \mathrm{and} \mathrm{Pb} \mathrm{was} \mathrm{eluted} \mathrm{with} 1 \mathrm{ml}$ of 6N HCl.

\subsection{Results}

\subsubsection{Organic carbon}

Total organic carbon concentrations decrease from $\sim 3 \mathrm{wt} . \%$ near the seafloor to 0.41 wt.\% close to the sill contact (Figure 5.3). These findings correlate well with previous measurements of TOC in this core (Curray et al., 1982; Galimov et al., 1982). A trend toward more negative $\delta^{13} \mathrm{C}$ close to the contact is also observed, indicating that the carbon lost due to thermal alteration was isotopically heavier than the bulk sediment. Both sill samples had very low TOC concentrations $(<0.03$ wt. $\%)$. The TOC concentrations level off farthest from the contact, indicating that we sampled far enough away from the intrusion to observe the organic carbon content of the sediments prior to thermal alteration. 
Total nitrogen concentrations were also measured over the profile and show depletion at depths close to the contact, similar to TOC concentrations (Figure 5.4). The depletion of N, however, is somewhat more gradual than the depletion of TOC, similar to what is observed in the Raton Basin field site (see chapter 4).

\subsubsection{Lead concentrations}

Lead concentrations were calculated following the isotope dilution method based on the measured ${ }^{208} \mathrm{~Pb} /{ }^{206} \mathrm{~Pb}$ ratios and the masses of spike and sample. Lead concentrations show no consistent trend with distance from contact (Figure 5.5), indicating lead was not lost during contact metamorphic processes. The deepest sample, closest to the sill contact, has much lower concentrations $(2.4 \mu \mathrm{g} / \mathrm{g})$, with unusually high lead concentrations $(\sim 35 \mu \mathrm{g} / \mathrm{g})$ immediately above, indicating that lead may have been mobilized during thermal alteration, but was redeposited into the sediments very close to the source. Lead concentrations similarly do not correlate well with TOC or total $\mathrm{N}$ concentrations, indicating no association between $\mathrm{Pb}$ and organic matter.

\subsubsection{Osmium isotope system}

Osmium concentrations decrease from $\sim 200 \mathrm{pg} / \mathrm{g}$ far from the contact to less than $90 \mathrm{pg} / \mathrm{g}$ at the measured location closest to the sill contact (Figure 5.6). Osmium concentrations are correlated very strongly with TOC concentrations, with a linear correlation coefficient of 0.94 (Figure 5.7).

Osmium isotopic compositions have a large uncertainty and show neither significant changes nor a consistent trend with depth (Figure 5.8). Average uncertainty of the isotope ratio is 0.02 , while the deviation from the mean is smaller than 0.015 for all but two of the samples. Similarly, there was no clear correspondance between the concentration and isotopic 
composition of osmium (Figure 5.9). A weak $\left(\mathrm{R}^{2}=0.69\right)$, but potentially significant correlation between Os isotope ratios and Os concentrations exists for the five samples closest to the contact (Figure 5.10), and shows a trend towards lower isotope ratios with lower concentrations. This may reflect that the osmium released is more radiogenic than the bulk sediment, indicative of mixing between less radiogenic detrital Os and more radiogenic Os associated with the hydrogenous component rich in organic matter.

\subsection{Discussion}

\subsubsection{Contact metamorphic processes}

Organic carbon contents of the non-metamorphosed sediments far from the intrusion are significantly higher than typical upper continental crust, indicating the primary depositional environment was suboxic or reducing. This is further confirmed by the elevated osmium concentrations (which range from 86 to $205 \mathrm{pg} / \mathrm{g}$, with an average of $\sim 195 \pm 7 \mathrm{pg} / \mathrm{g}$ in the unaltered sediments) relative to continental crust, which has been estimated at between 31 and 50 pg/g (Peucker-Ehrenbrink and Jahn, 2001; Esser and Turekian, 1993).

Osmium, carbon, and nitrogen concentrations decrease significantly within the metamorphic aureole close to the sill intrusion. Osmium concentrations correlate very well with organic carbon, but the linear relationship indicates residual Os, $\sim 60 \mathrm{pg} / \mathrm{g}$ based on the intercept at zero TOC concentration (Figure 5.7), remains after the organic carbon has been fully depleted. This remaining Os indicates the presence of Os in a phase not associated with organic carbon, such as Os associated with detrital material. The presence of both authigenic and detrital components was also noted in the types of organic matter found in the sediments (Galimov et al., 1982; Simoneit and Philp, 1982; Gilbert and Summerhayes, 1982; Galimov and Simoneit, 1982). Isotopically the two host-phases of Os are difficult to distinguish, because modern hydrogenous 
osmium, derived from seawater, has an isotopic composition of $\sim 1.05$ (Peucker-Ehrenbrink and Ravizza, 2000), which within uncertainty is identical to average detrital osmium with isotope compositions ranging from $\sim 0.5$ to $\sim 1.5$ (Esser and Turekian, 1993; Peucker-Ehrenbrink and Ravizza, 2000).

Sampling across depositional strata introduces the possibility that changes in composition may be caused by changes in primary deposition rather than thermal alteration. A comparison between the metamorphosed strata to unaltered bedding planes, which would assist in untangling primary processes from post-depositional metamorphic processes, is not feasible at this site due to a high degree of regional variability in the geology of the rift, perhaps due to turbidite flows and abundant faulting (Curry et al., 1982). Previous studies of these sediments also indicate that porosity decreased and pore water was expelled, consistent with a thermal rather than microbial cause of carbon loss (Schoell, 1988; Whitcar, 1999). Additionally, mineralogical assemblages also indicate high levels of thermal alteration (Kastner, 1982).

Additional approaches to determine the extent of thermal alteration suggest contact metamorphism as the cause of carbon loss. Interstitial gas contains light hydrocarbons indicative of thermogenesis with very negative $\delta^{13} \mathrm{C}$ (Whelan and Hunt, 1982; Galimov and Simoneit, 1982; Simoneit and Galimov, 1984). Bitumen fractions and the makeup of the n-alkenes similarly indicate high levels of thermogenic alteration of the sediments at DSDP Site 477 (Galimov et al., 1982).

Additional lines of evidence could be examined to rule out the possibility that the Os and TOC concentration differences could be caused by the presence of a turbidite with low TOC concentrations. For instance, examination of major and trace elements typically found in detrital 
sediments, such as $\mathrm{Th}, \mathrm{Zr}$ or $\mathrm{Ti}$, would allow me to normalize the Os and $\mathrm{C}$ concentrations to determine whether concentration changes are primary or due to thermal alteration.

The relative mobilization rates of osmium and organic carbon are calculated by integration using the trapezoidal approximation of the total mass of each element lost over the profile. The baseline concentrations were assumed to be the average concentration of the four samples farthest away from the intrusive contact. Using this method, a total of $6.1 \times 10^{9}$ moles organic carbon was released for each mole of osmium released. This is higher than the TOC/Os ratio of sediments in the Guaymas Basin $\left(2.4 \times 10^{9}\right)$ due to the additional detrital contribution of osmium in these shales, which is not mobilized with the organic carbon. However, the observed ratio is identical to the estimated TOC/Os molar ratio of black shales in general $\left(6.1 \times 10^{9}\right.$; see chapter 2).

\subsubsection{Lead isotopes at the PETM}

The Guaymas Basin is considered a potential submarine analog for the late Paleoceneearly Eocene North Atlantic Magmatic Province and is therefore used to determine whether or not $\mathrm{Pb}$ might be released along with organic carbon during contact metamorphic processes. As no significant mobilization of $\mathrm{Pb}$ is observed within the aureole, the $\mathrm{U}-\mathrm{Th}-\mathrm{Pb}$ isotope system cannot be used to determine whether contact metamorphic processes contributed to the carbon isotope excursion during the PETM. Lead may have been mobilized only very close to the contact, but redeposited directly above, explaining the low $\mathrm{Pb}$ concentration close to the magmatic contact and slightly elevated concentrations a few centimeters above. Lead mobilized in this manner likely never reached the surface because it was likely redeposited onto detrital sediments nearby and thus never entered the ocean-atmosphere system. 


\subsubsection{Osmium isotope excursion at the PETM}

The ratio of organic carbon to osmium mobilized during contact metamorphism can be used to estimate what fraction of the PETM carbon isotope excursion might have been caused by contact metamorphism from magmatic intrusions in the NAMP. Assuming that the entire marine Os isotope excursion observed by Ravizza et al. (2001) was caused from Os release during contact metamorphism, the system of equations introduced in chapter 1 can be used. I assume that the relative contributions of Os from both hydrothermal and riverine sources remain unchanged during the PETM.

Realistic values for the ${ }^{187} \mathrm{Os} /{ }^{188} \mathrm{Os}$ of organic-rich sediments at the time of the PETM are determined by assuming that magmas of the NAMP intruded into sediments of Cretaceous and Paleocene age (Brekke et al., 1999; Brekke, 2000) with a constant deposition rate between 90 and $56 \mathrm{Ma}$. The initial ${ }^{187} \mathrm{Os} /{ }^{188}$ Os ratios of those sediments at the time of deposition are assumed to be equal to that of contemporaneous seawater (Peucker-Ehrenbrink and Ravizza, 2012). I use a value of 311 for the ${ }^{187} \mathrm{Re} /{ }^{188} \mathrm{Os}$ of black shales based on the TOC content of sediments from the NAMP (mean TOC of $1.4 \mathrm{wt} . \%$ with one standard deviation of 0.44 ; Svensen et al., 2004) and the linear relationship between TOC and ${ }^{187} \mathrm{Re} /{ }^{188}$ Os reported in Chapter 2. The error on the ${ }^{187} \mathrm{Re} /{ }^{188}$ Os of black shales, based on the standard deviation on TOC as well as the error on the estimate of the slope of the relationship to ${ }^{187} \mathrm{Re} /{ }^{188} \mathrm{Os}$, is 93 . Using these assumptions, the ${ }^{187} \mathrm{Os} /{ }^{188}$ Os of these sediments at the time of the PETM was $0.62 \pm 0.03$.

Using the system of equations presented in Chapter 1 , the mole fraction of ${ }^{188} \mathrm{Os}$ in seawater from organic-rich sediments during the PETM is 0.25 . Using this $F_{o}$ value and assuming an average dissolved Os concentration of $10 \mathrm{pg} / \mathrm{L}$ in seawater during the PETM (identical to today), a total of $1.8 \times 10^{7} \mathrm{~mol}$ Os were released from organic-rich sediments during 
the PETM. Given the TOC/Os mobilization ratio of $6.1 \times 10^{9}$ determined above, $\sim 1300$ gigatonnes $(\mathrm{Gt})$ of $\mathrm{C}_{\text {org }}$ would have been released during contact metamorphism. This is a significant fraction $(\sim 53 \%)$ of the $\mathrm{C}_{\text {org }}$ estimates of carbon released during the PETM ( $2500 \mathrm{Gt}$, with $\delta^{13} \mathrm{C}$ of the organic matter between -35 and $-50 \%$ ). Assuming the sediments have an organic carbon content of 1.4 wt. $\%$, this implies a volume of $\sim 93,000 \mathrm{Gt}\left(9.3 \times 10^{16} \mathrm{~kg}\right)$ of organic-rich sediment that must have lost its entire $\mathrm{C}_{\text {org }}$ inventory during thermal alteration to release $1300 \mathrm{Gt}$ of carbon. This corresponds to a total sediment volume of $46,500 \mathrm{~km}^{3}$ ( $\rho=2$ $\left.\mathrm{g} / \mathrm{cm}^{3}\right)$. This volume is two orders of magnitude smaller than the estimated size of the North Atlantic Magmatic Province (Svensen et al., 2004), and is well within reasonable estimates of the amount of sediments that could have been affected by thermal alteration.

Small differences in the assumed ${ }^{187} \mathrm{Os} /{ }^{188} \mathrm{Os}$ of the sediments in the NAMP can yield large differences in the calculated fraction of carbon at the PETM from organic-rich sediments (Figure 5.11). Using the mean and error estimates of the ${ }^{187} \mathrm{Os} /{ }^{188} \mathrm{Os}(0.62 \pm 0.03)$ gives a range between $47 \%$ and $60 \%$ of the carbon at the PETM coming from organic-rich sediments. A reasonable upper bound would be to assume a ${ }^{187} \mathrm{Re} /{ }^{188} \mathrm{Os}$ value of 517 (the median of the sediments in the database, see Chapter 2) and assume all of the intruded sediments were deposited during the late Cretaceous, for instance at $90 \mathrm{Ma}$. This ${ }^{187} \mathrm{Re} /{ }^{188} \mathrm{Os}$ estimate is likely too high as many of the sediments in the database have TOC concentrations significantly higher than the sediments in the NAMP. Additionally, the volume-age distribution of the intruded sediments is unknown, but deposition likely occurred more recently than 90 Ma. However, these assumptions provide a reasonable upper bound on the ${ }^{187} \mathrm{Os} /{ }^{188} \mathrm{Os}$ of 0.89 , corresponding to a lower bound on the fraction of carbon at the PETM that is derived from metamorphosed sediments of $25 \%$. 


\subsection{Conclusions}

DSDP Site 477 in the Guaymas Basin was sampled as a potential analog to the thermal alteration of organic-rich sediments in the NAMP that may have occurred during the PETM. Both organic carbon and osmium were released during contact metamorphic processes at this site. Not all osmium is mobilized along with the organic carbon, indicating the presence of an additional detrital host phase of osmium in the sediments. Making reasonable assumptions for the ${ }^{187} \mathrm{Os} /{ }^{188} \mathrm{Os}$ of the sediments from the NAMP, the entire marine osmium isotope anomaly could be explained without the need for enhanced continental weathering as invoked by Ravizza et al. (2001). Based on estimates of the extent of mobilization of organic carbon to osmium and estimates of ${ }^{187} \mathrm{Os} /{ }^{188} \mathrm{Os}$ based on the ${ }^{187} \mathrm{Re} /{ }^{188} \mathrm{Os}$ estimates derived from the TOC concentrations in the NAMP, approximately $47 \%$ to $60 \%$ of the carbon released at the PETM may have been derived from thermal alteration of organic-rich sediments in the NAMP.

The Os isotope anomaly at the PETM does not require Os derived from the NAMP, but could be fully explained by enhanced continental Os from rivers as proposed by Ravizza et al. (2001). However, I offer an alternative hypothesis for the source of the Os at the PETM. While the Os isotope system alone cannot distinguish between these two sources of Os, the interpretation of the Os isotope anomaly at the PETM should take into account the possibility of Os from the NAMP in addition to enhanced continental runoff. The Os anomaly associated with other hyperthermals such as the ELMO event (see Figure 1.2) is temporally concurrent with the opening of the Norwegian-Greenland Sea (Lundin and Dore, 2002) and could be caused by a similar process. Lead was not mobilized to the overlying seawater and therefore cannot be used as a proxy for carbon release from organic-rich sediments during the PETM. 


\begin{tabular}{ccccccc}
\hline Sample & $\begin{array}{c}\text { Depth in } \\
\text { core (mbsf) }\end{array}$ & ${ }^{187}$ Os $/{ }^{188}$ Os & $\begin{array}{c}{ }^{187} \text { Os } /{ }^{188} \text { Os } \\
\text { error }\end{array}$ & {$[\mathrm{Os}](\mathrm{pg} / \mathrm{g})$} & {$[\mathrm{Os}]$ error } & {$[\mathrm{Pb}](\mu \mathrm{g} / \mathrm{g})$} \\
\hline GB02 & 12.19 & 1.110 & 0.006 & 191.2 & 0.8 & 18.8 \\
GB04 & 20.225 & 1.087 & 0.006 & 198.9 & 1.0 & 22.6 \\
GB06 & 21.175 & 1.097 & 0.020 & 186.8 & 0.8 & 23.3 \\
GB07 & 29.625 & 1.090 & 0.011 & 205.3 & 1.3 & 29.5 \\
GB10 & 31.945 & 1.094 & 0.010 & 190.5 & 1.1 & 16.1 \\
GB12 & 48.585 & 1.139 & 0.012 & 171.8 & 0.8 & 17.3 \\
GB15 & 49.515 & 1.110 & 0.010 & 146.3 & 0.7 & 38.9 \\
GB16 & 49.715 & 1.116 & 0.010 & 100.5 & 0.5 & 35.5 \\
GB18 & 50.34 & 1.099 & 0.083 & 95.2 & 1.2 & 35.4 \\
GB19 & 50.54 & 1.068 & 0.014 & 85.8 & 0.9 & 2.42 \\
GB20 & 60.45 & 0.313 & 0.002 & 323.6 & 1.5 & 0.736 \\
GB21 & 77.965 & 0.309 & 0.005 & 258.6 & 1.5 & 0.909 \\
\hline
\end{tabular}

Table 5.1 Present-day $\mathrm{Os}$ and $\mathrm{Pb}$ isotope compositions and concentrations in Guaymas Basin sediment samples. Errors are defined by a single standard deviation ( 1 s.d.) on the isotope ratio measurement. Realistic uncertainties of the $\mathrm{Pb}$ concentration analyses are $\sim 1 \%$ (1 s.d.). GB20 and GB21 are intrusive rocks. "mbsf" is "meters below sea floor". 


\begin{tabular}{|c|c|c|c|c|c|c|c|c|c|}
\hline Sample & $\begin{array}{l}\text { Depth in } \\
\text { core (mbsf) }\end{array}$ & TOC (wt.\%) & TOC error & $\delta^{13} \mathrm{C}$ & $\delta^{13} \mathrm{C}$ error & $\mathrm{N}$ (wt.\%) & $\% \mathrm{~N}$ error & $\delta^{15} \mathrm{~N}$ & $\delta^{15} \mathrm{~N}$ error \\
\hline GB01 & 11.07 & 1.24 & 0.016 & -20.8 & 0.1 & 0.14 & 0.002 & 10.6 & 0.1 \\
\hline GB02 & 12.19 & 3.10 & 0.074 & -20.4 & 0.1 & 0.38 & 0.020 & 11.2 & 0.6 \\
\hline GB03 & 13.075 & 3.01 & 0.023 & -20.4 & 0.1 & 0.36 & 0.012 & 11.3 & 0.2 \\
\hline GB04 & 20.225 & 3.03 & 0.011 & -20.5 & 0.1 & 0.35 & 0.020 & 11.3 & 0.6 \\
\hline GB05 & 20.695 & 3.00 & 0.172 & -20.6 & 0.3 & 0.33 & 0.008 & 11.5 & 0.2 \\
\hline GB06 & 21.175 & 2.84 & 0.038 & -20.5 & 0.0 & 0.32 & 0.003 & 11.5 & 0.4 \\
\hline GB07 & 29.625 & 2.80 & 0.029 & -20.6 & 0.0 & 0.31 & 0.006 & 11.8 & 0.2 \\
\hline GB08 & 30.355 & 2.55 & 0.022 & -20.5 & 0.0 & 0.29 & 0.009 & 11.5 & 0.3 \\
\hline GB09 & 31.325 & 2.00 & 0.044 & -20.6 & 0.1 & 0.22 & 0.006 & 12.0 & 0.8 \\
\hline GB10 & 31.945 & 2.49 & 0.065 & -20.7 & 0.1 & 0.26 & 0.002 & 12.0 & 0.8 \\
\hline GB11 & 32.355 & 2.48 & 0.023 & -20.6 & 0.1 & 0.24 & 0.002 & 10.9 & 0.3 \\
\hline GB12 & 48.585 & 2.30 & 0.018 & -20.8 & 0.1 & 0.15 & 0.005 & 9.9 & 0.9 \\
\hline GB13 & 48.875 & 2.45 & 0.036 & -20.8 & 0.1 & 0.17 & 0.003 & 10.4 & 0.6 \\
\hline GB14 & 49.175 & 1.36 & 0.015 & -20.7 & 0.1 & 0.10 & 0.005 & 11.3 & 1.1 \\
\hline GB15 & 49.515 & 1.81 & 0.008 & -20.9 & 0.1 & 0.13 & 0.003 & 9.9 & 0.7 \\
\hline GB16 & 49.715 & 1.31 & 0.013 & -21.7 & 0.0 & 0.08 & 0.005 & 8.8 & 2.0 \\
\hline GB17 & 50.105 & 1.74 & 0.052 & -21.0 & 0.2 & 0.13 & 0.019 & 9.9 & 0.6 \\
\hline GB18 & 50.34 & 0.74 & 0.019 & -21.4 & 0.2 & 0.05 & 0.005 & 12.5 & 1.1 \\
\hline GB19 & 50.54 & 0.41 & 0.014 & -20.7 & 0.0 & 0.04 & 0.002 & 12.5 & 3.1 \\
\hline GB20 & 60.45 & 0.025 & 0.008 & -27.3 & 2.5 & & & & \\
\hline GB21 & 77.965 & 0.018 & 0.001 & -27.3 & 0.7 & & & & \\
\hline
\end{tabular}

Table 5.2 Total organic carbon and total nitrogen concentrations of the samples from the Guaymas Basin and the respective isotope compositions relative to PDB. Errors are defined by twice the standard deviation (2 s.d.) on the measurement, based on three replicates. 


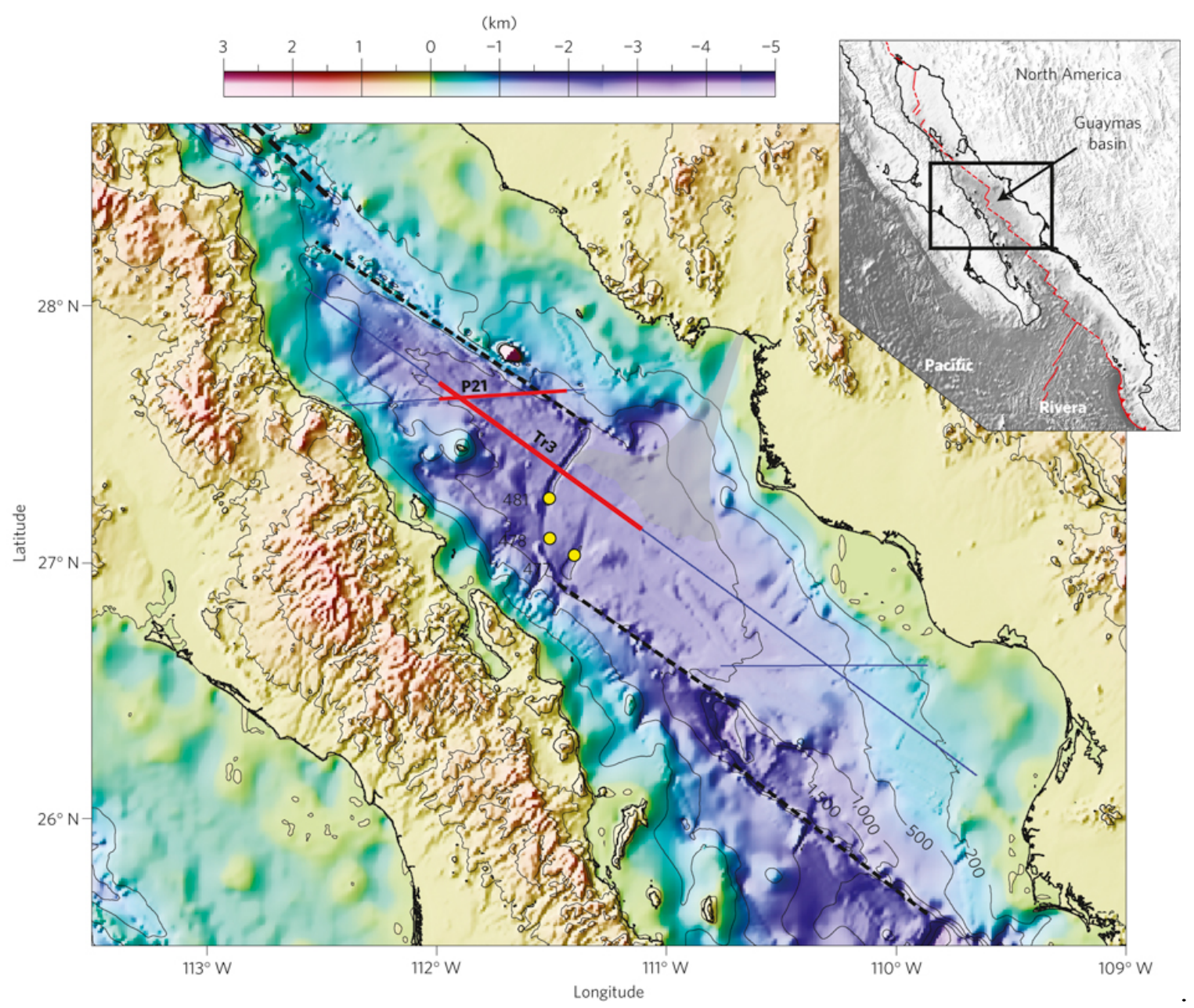

Figure 5.1 Bathymetry of the Guaymas Basin within the Gulf of California. DSDP Site 477 is located at the southern-most yellow dot indicated on the map. Image taken from Lizarralde et al., 2011. 


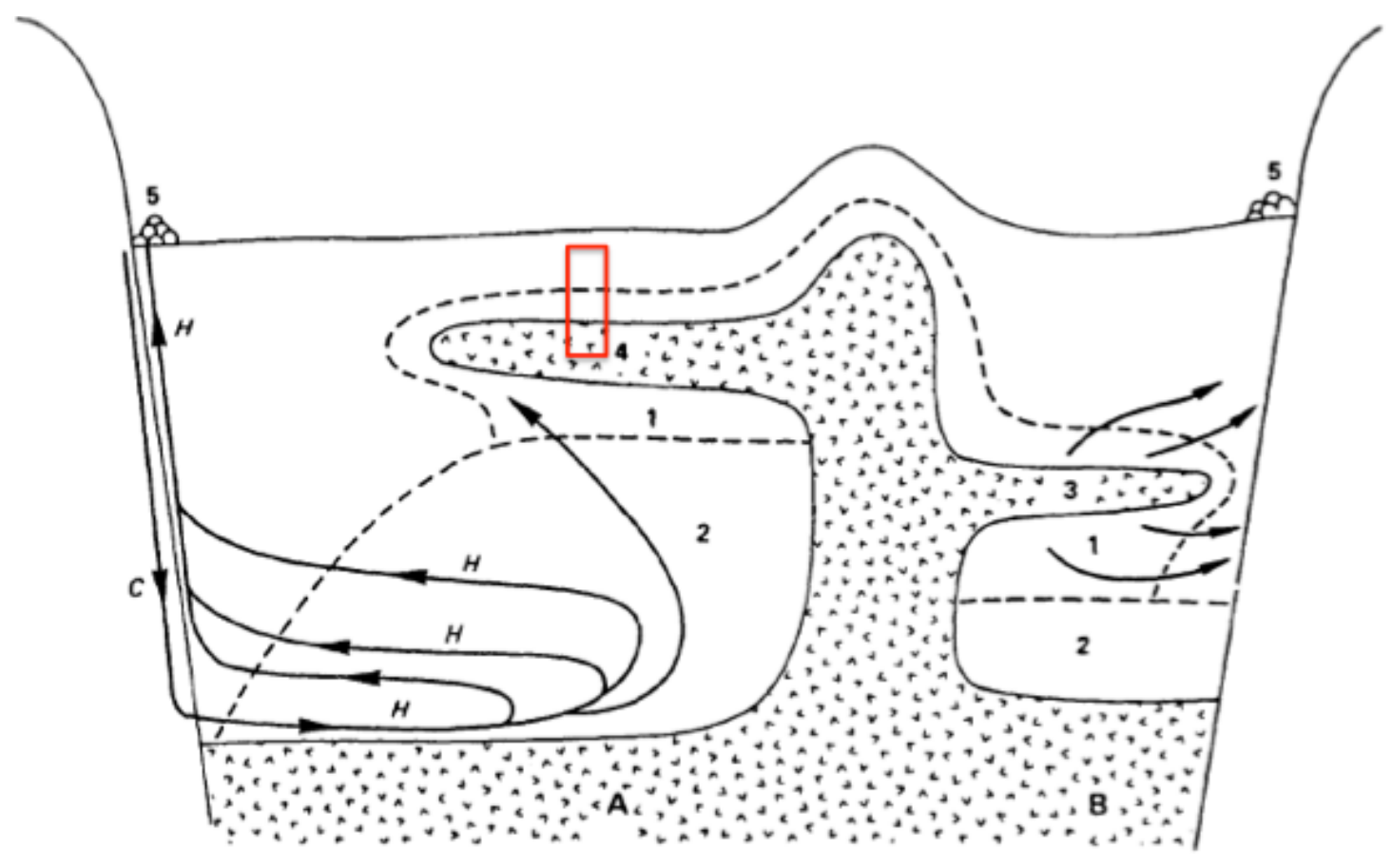

Figure 5.2 Schematic of DSDP Site 477 (A) in the Guaymas Basin. Zone 1 represents the areas affected by the uppermost sill intrusion, zone 2 represents the areas affected by deeper sill intrusions, and zone 4 represents the uppermost doloritic sill, acting as a lid to the hydrothermal fluid circulated underneath. The red rectangular box represents the profile I sampled. Image taken from Simoneit et al., 1986. 




Figure 5.3 Total organic carbon concentrations (A) and $\delta^{13} \mathrm{C}(\mathrm{B})$ of the Guaymas Basin bulk sediment samples. Red circles indicate those samples chosen based on their TOC content for Os and $\mathrm{Pb}$ analyses. Note the depletion in organic carbon close to the sill contact (58 mbsf). 


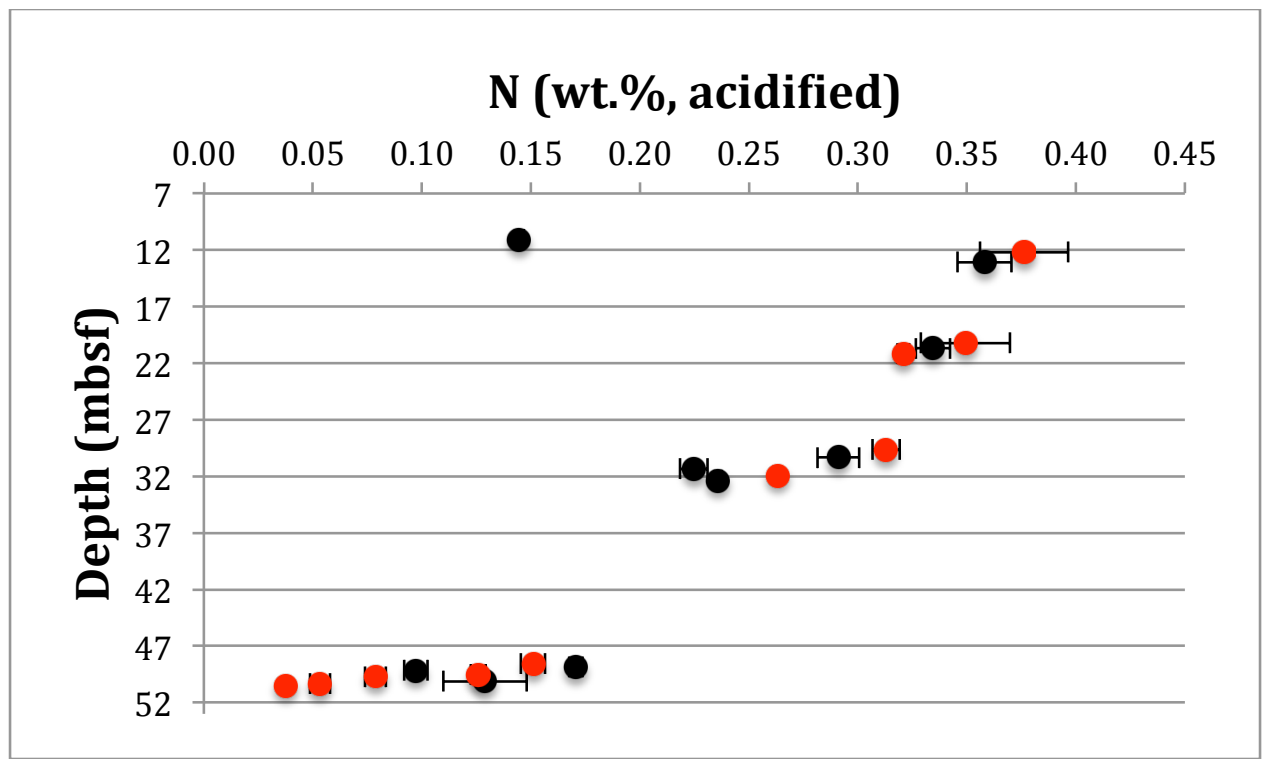

Figure 5.4 Total nitrogen concentrations of the Guaymas Basin bulk sediment samples. Estimates of the uncertainties represent two standard deviations based on three replicate analyses. Red circles indicate those samples chosen for Os and $\mathrm{Pb}$ analyses based on their TOC contents. 




Figure 5.5 Lead concentrations in the Guaymas Basin bulk sediment samples from the DSDP Site 477 profile. 




Figure 5.6 Osmium concentrations of the bulk sediment from samples from the Guaymas Basin DSDP Site 477. 




Figure 5.7 Osmium and TOC concentrations of the Guaymas Basin bulk sediment correlate very strongly (linear correlation coefficient of 0.94), indicating that Os is lost together with TOC during contact metamorphism in subaqueous environments. The best fit least squares linear regression line is shown in blue. 


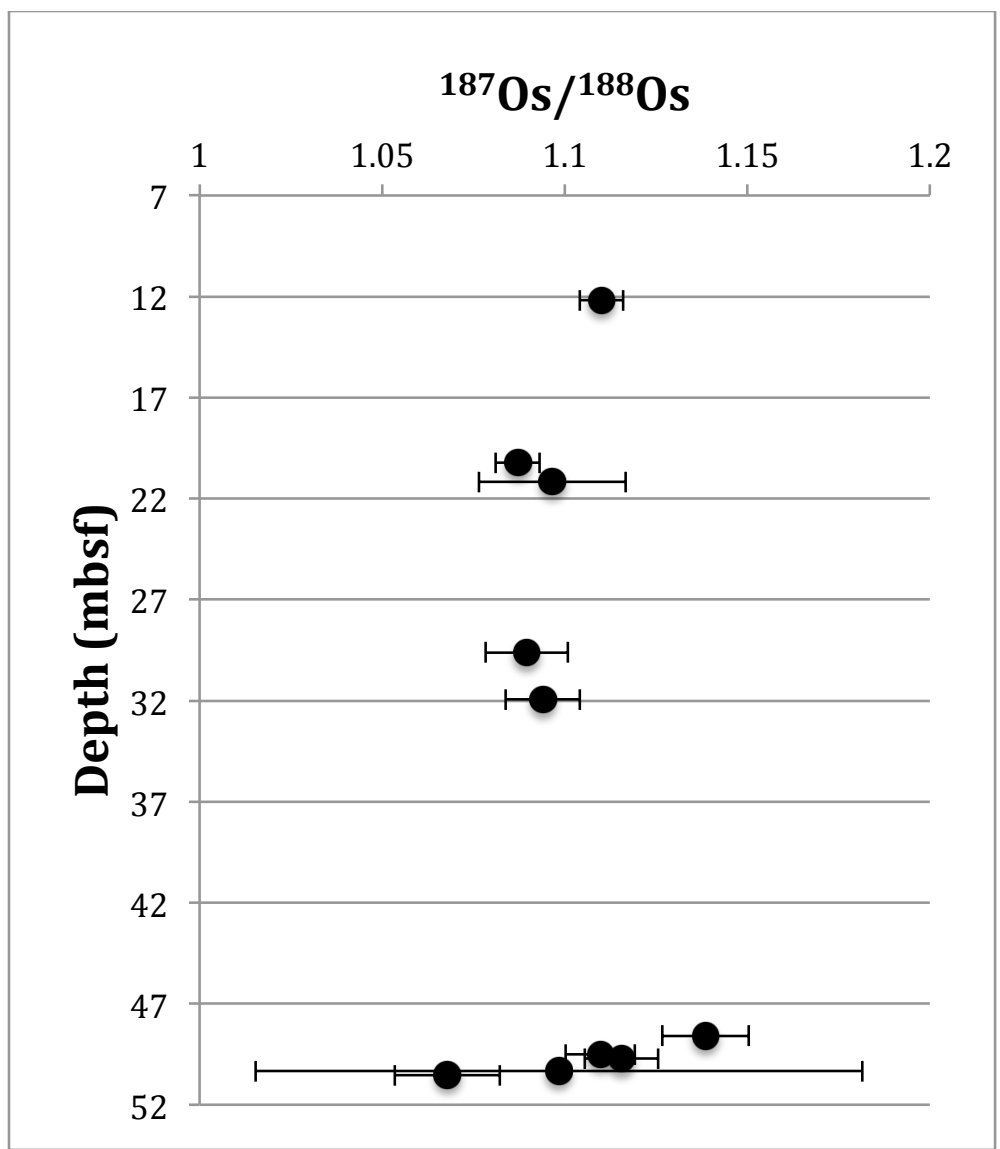

Figure 5.8 Osmium isotopic composition of Guaymas Basin bulk sediment samples plotted against depth at DSDP Site 477. Error bars indicate 1 s.d. 




Figure 5.9 Osmium isotope composition compared to inverse osmium concentrations in Guaymas Basin DSDP Site 477 samples. 


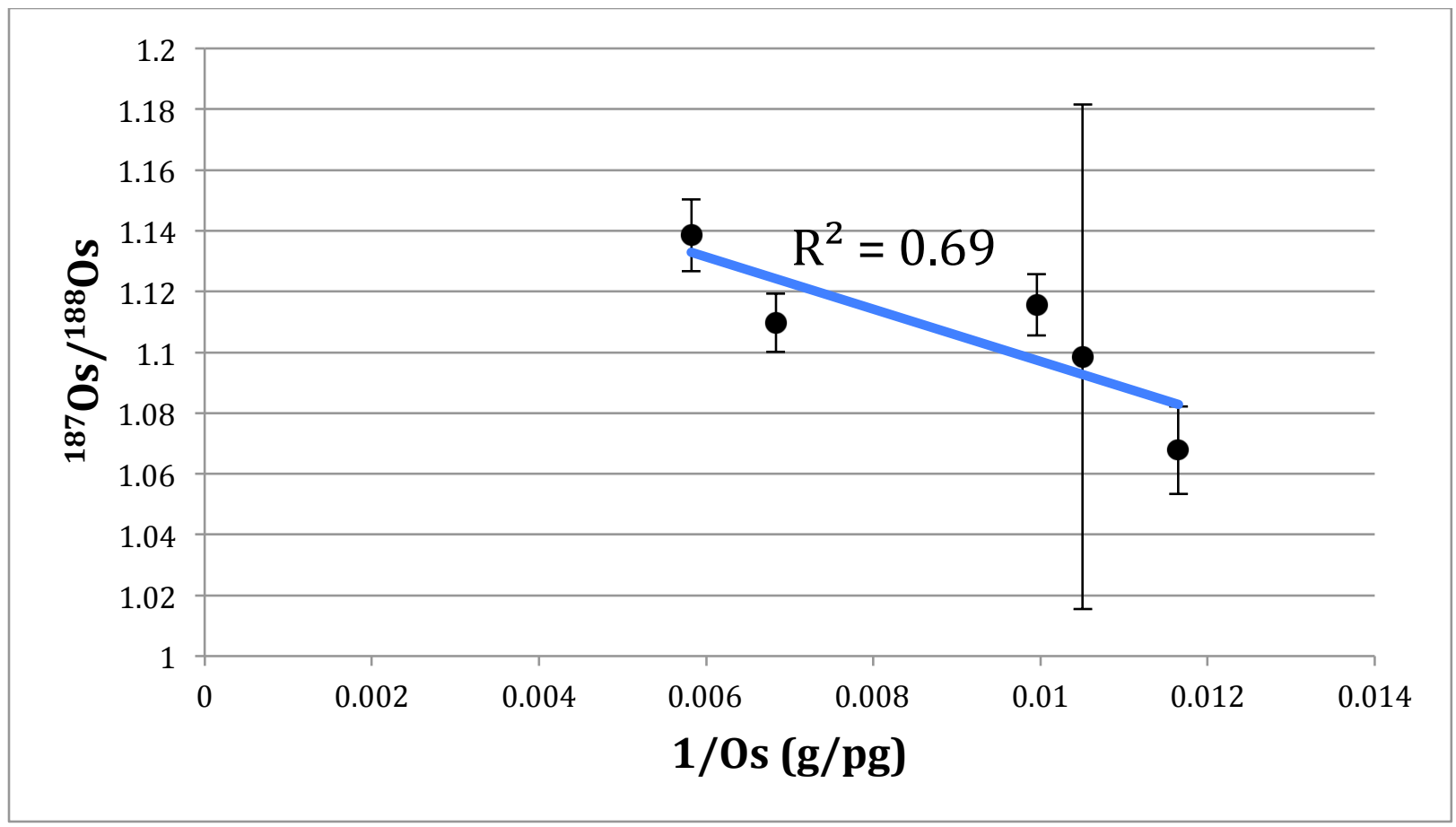

Figure 5.10 Linear mixing relationship between Os isotope composition and Os concentrations for the five samples closest to the intrusive contact in the sediments at DSDP Site 477. 


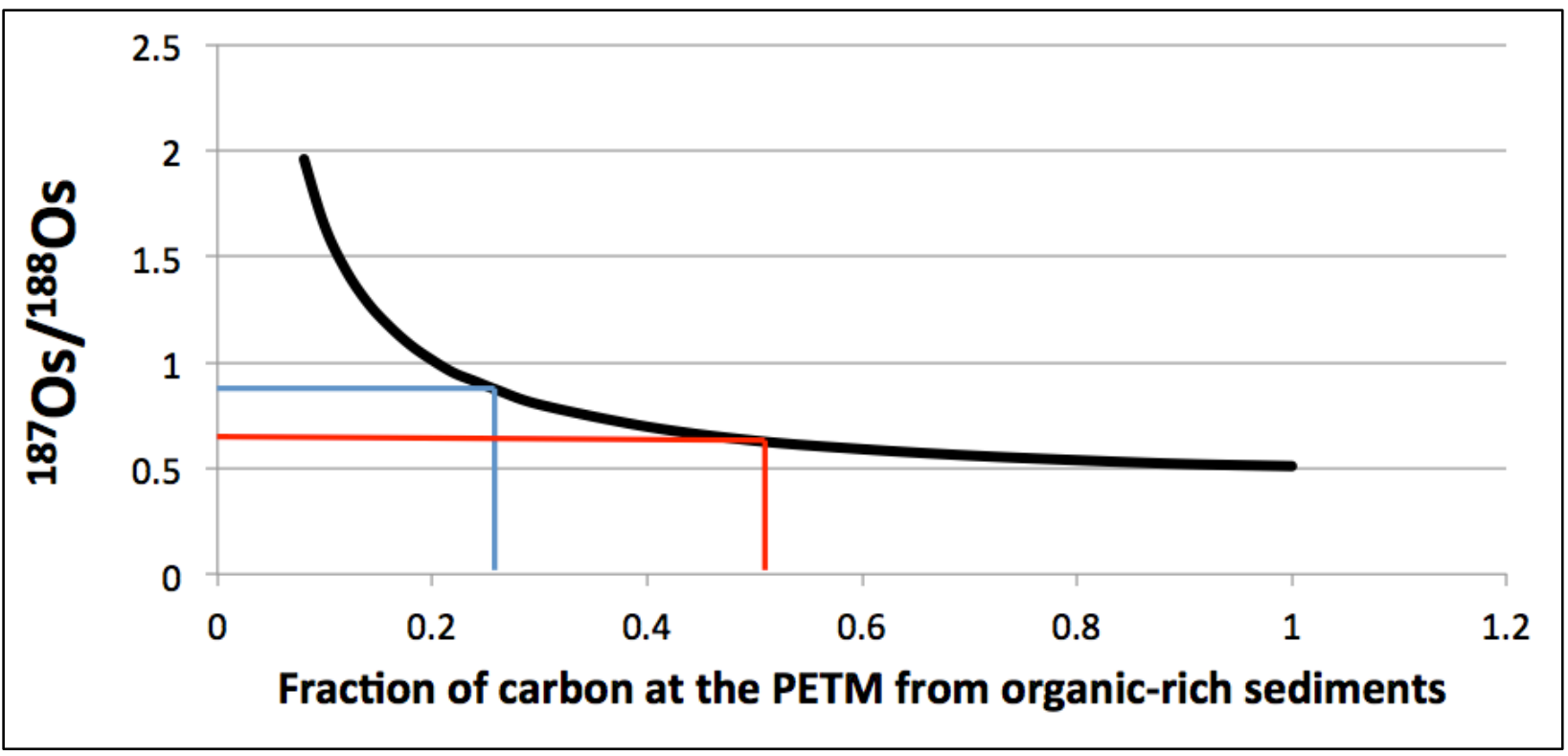

Figure 5.11 Relationship between the calculated fraction of organic carbon at the PETM derived from organic-rich sediments, and the ${ }^{187} \mathrm{Os} /{ }^{188}$ Os of those sediments. The blue line indicates the upper bound estimate $(0.89)$ for the ${ }^{187} \mathrm{Os} /{ }^{188} \mathrm{Os}$, while the red line represents the ${ }^{187} \mathrm{Os} /{ }^{188} \mathrm{Os}$ estimate (0.62) that is based on the TOC content of the NAMP. 


\subsection{References}

Brekke, H., 2000. The tectonic evolution of the Norwegian Sea continental margin with emphasis on the Voring and More Basins. Geological Society Special Publications 167, 327-378.

Brekke, H., Dahlgren, S., Nyland, B., Magnus, C., 1999. The prospectivity of the Voring and More basins on the Norwegian Sea continental margin, In: Petroleum Geology of Northwest Europe: Proceedings of the 5th Conference (eds. Fleet, A.J., Boldy, S.A.R.) 261-274.

Cohen, A.S., Coe, A.L., Bartlett, J.M., Hawkesworth, C.J. 1999. Precise Re-Os ages of organicrich mudrocks and Os isotope composition of Jurassic seawater. Earth and Planetary Science Letters 167, 159-173.

Colodner, D., Sachs, J., Ravizza, G., Turekian, K.K., Edmond, J., Boyle, E., 1993. The geochemical cycle of rhenium: a reconnaissance. Earth and Planetary Science Letters 117, 205221.

Cruse, A.M., Seewald, J.S., 2001. Metal mobility in sediment-covered ridge-crest hydrothermal systems: experimental and theoretical constraints. Geochimica et Cosmochimica Acta 65, 32333247.

Curray, J.R., Moore, D.G., Aguayo, J.E. et al., 1982. Initial Reports of the Deep Sea Drilling Project, Vol. 64, Parts 1 and 2, US Govt. Print. Office, Washington, D.C., 1313 pp.

Disnar, J.R., Sureau, J.F., 1995. Organic matter in ore genesis: Progress and perspectives. Organic Geochemistry 16, 577-599.

Esser, B.K., Turekian, K.K., 1993. The osmium isotopic composition of the continental crust. Geochimica et Cosmochimica Acta 57, 3093-3104.

Galimov, E.M., Simoneit, B.R.T., 1982. Geochemistry of interstitial gases in sedimentary deposits of the Gulf of California, Deep Sea Drilling Project Leg 64, In: Initial Reports of the Deep Sea Drilling Project, Vol. 64, (Eds. Curray, J.R., Moore, D.G., et al.) US Govt. Print. Office, Washington, D.C., pp. 781-788.

Galimov, E.M., Kodina, L.A., Bogacheva, M.P., Shirinsky, V.G., 1982. Organic geochemical studies of samples from Deep Sea Drilling Project Leg 64, Gulf of California, Sites 474, 477, 478, 479, and 481, In: Initial Reports of the Deep Sea Drilling Project, Vol. 64, (Eds. Curray, J.R., Moore, D.G., et al.) US Govt. Print. Office, Washington, D.C., pp. 819-836

Gieskes, J., Elderfield, H., Lawrence, J.R., Johnson, J., Meyers, B., Campbell, A., 1982. Geochemistry of interstitial waters and sediments, Leg 64, Gulf of California, In: Initial Reports of the Deep Sea Drilling Project, Vol. 64, (Eds. Curray, J.R., Moore, D.G., et al.) US Govt. Print. Office, Washington, D.C., pp. 675-694. 
Gilbert, D., Summerhayes, C.P., 1982. Organic facies and hydrocarbon potential in the Gulf of California. In: Initial Reports of the Deep Sea Drilling Project, Vol. 64, (Eds. Curray, J.R., Moore, D.G., et al.) US Govt. Print. Office, Washington, D.C., pp. 865-870.

Kastner, M., 1982. Evidence for two distinct hydrothermal systems in the Guaymas Basin. In: Initial Reports of the Deep Sea Drilling Project, Vol. 64, (Eds. Curray, J.R., Moore, D.G., et al.) US Govt. Print. Office, Washington, D.C., pp. 1143-I158.

Levasseur, S., Rachold, V., Brick, J.L., Allegre, C.J., 2000. Osmium behaviour in estuaries: the Lena River example. Earth and Planetary Science Letters 177, 227-235.

Lizarralde, D., Soule, S.A., Seewald, J.S., Proskurowski, G., 2011. Carbon release by off-axis magmatism in a young sedimented spreading centre. Nature Geoscience 4, 50-54.

Lundin, E., Dore, A.G., 2002. Mid-Cenozoic post-breakup deformation in the 'passive' margins bordering the Norwegian-Greenland Sea. Marine and Petroleum Geology 19, 79-93.

Peucker-Ehrenbrink, B., Jahn, B.M., 2001. Rhenium-osmium isotope systematics and platinum group element systematics: Loess and the upper continental crust. Geochemisty, Geophysics, Geosystems 2, $2001 \mathrm{GC} 000172$.

Peucker-Ehrenbrink, B., Ravizza, G., 2000. The marine osmium isotope record. Terra Nova 5, 12, 205-219.

Peucker-Ehrenbrink, B., Ravizza, G., 2012. Osmium Isotope Stratigraphy. In: The Geologic Time Scale 2012. (F.M. Gradstein, J.G. Ogg, M.D. Schmitz, G.M. Ogg, Eds.), Elsevier, Oxford, $\mathrm{UK}, 23 \mathrm{pp}$.

Ravizza G., Norris, R.N., Blusztajn, J., Aubry, M.-P., 2001. An osmium isotope excursion associated with the late Paleocene thermal maximum: Evidence of intensified chemical weathering. Paleoceanography 16, 155-163.

Ravizza, G., Turekian, K.K., 1989. Application of the ${ }^{187}$ Re- ${ }^{187}$ Os system to black shale geochronometry. Geochimica et Cosmochimica Acta 53, 3257-3262.

Ravizza, G., Turekian, K.K., Hay, B.J., 1991. The geochemistry of rhenium and osmium in recent sediments from Black Sea. Geochimica et Cosmochimica Acta 55, 3741-3752.

Schoell, M., 1988. Multiple origins of methane in the earth. Chemical Geology 71, 1-10.

Seewald, J.S., Seyfried, W.E., Thornton, E.C., 1990. Organic-rich sediment alteration; an experimental and theoretical study at elevated temperatures and pressures. Applied Geochemistry 5, 193-209.

Selby, D., Creaser, R.A., 2003. Re-Os geochronology of organic-rich sediments: an evaluation of organic matter analysis. Chemical Geology 200, 225-240. 
Simoneit, B.R.T., Philp, R.P., 1982. Organic geochemistry of lipids and kerogen and the effects of basalt intrusions on unconsolidated oceanic sediments: Sites 477, 478, and 481, Guaymas Basin, Gulf of California, In: Initial Reports of the Deep Sea Drilling Project, Vol. 64, (Eds. Curray, J.R., Moore, D.G., et al.) US Govt. Print. Office, Washington, D.C., pp. 883-904.

Simoneit, B.R.T., Galimov, E.M., 1984. Geochemistry of interstitial gases in Quaternary sediments of the Gulf of California. Chemical Geology 43, 151-166

Simoneit, B.R.T., Summerhayes, C.P., Meyers, P.A., 1986. Sources and hydrothermal alteration of organic matter in Quaternary sediments: a synthesis of studies from the Central Gulf of California. Marine and Petroleum Geology 3, 282-297.

Stock, J.M., Lee, J., 1994. Do microplates in subduction zones leave a geological record? Tectonics 13, 1472-1487.

Svensen, H, Planke, S., Melthe-Sørenssen, A., Jamtveit, B., Myklebust, R., Rasmussen Eidem, T., Rey, S.S., 2004. Release of methane from a volcanic basin as a mechanism for initial Eocene global warming. Nature 429, 542-545.

Whelan, J.K., Hunt, J.M., 1982. C1-C8 hydrocarbons in Leg 64 sediments, Gulf of California, In: Initial Reports of the Deep Sea Drilling Project, Vol. 64, (Eds. Curray, J.R., Moore, D.G., et al.) US Govt. Print. Office, Washington, D.C., pp. 763-779.

Whitcar, M.J., 1999. Carbon and hydrogen isotope systematics of bacterial formation and oxidation of methane. Chemical Geology 161, 291-314. 


\section{CHAPTER 6.}

\section{Conclusions}

\subsection{Summary of contributions}

The Paleocene-Eocene Thermal Maximum is a unique and intriguing event in earth's history. As described in chapter 1, this dramatic climate event occurred and caused widespread environmental and ecological consequences. Despite the severity of this event, the scientific community has not reached consensus as to its likely cause(s). My thesis focuses on whether evidence supports the hypothesis proposed by Svensen et al. (2004) that the CIE is caused by thermal alteration of organic-rich sediments occurring due to contact metamorphism during the rifting-related magmatism in the North Atlantic Basin.

In chapter 2, I examine the effect of organic-rich sediment on the cycling of osmium and rhenium in the oceans. While these sediments are very rare on the earth's surface, the reducing environments under which they are deposited causes them to acquire elevated concentrations of Re and Os, as well as a high Re/Os ratio relative to average continental crust. I compile a database of published values on the Re, Os, and TOC concentrations of such sediments, as well as their ${ }^{187} \mathrm{Re} /{ }^{188} \mathrm{Os}$ and ${ }^{187} \mathrm{Os} /{ }^{188} \mathrm{Os}$. This database is used to estimate the ${ }^{187} \mathrm{Re} /{ }^{188} \mathrm{Os}$ of organicrich sediments based on TOC content of this reservoir. The median ${ }^{187} \mathrm{Re} /{ }^{188} \mathrm{Os}$ value, combined with estimates of the abundance of organic-rich sediments in the geologic record, is used to determine an estimate of the average ${ }^{187} \mathrm{Os} /{ }^{188} \mathrm{Os}$ of organic-rich sediment. Values vary between 2.22 and 2.27 depending on the volume-age model used, with error estimates of 2.07 to 2.42 and 2.12 to 2.48 , respectively. I demonstrate that the calculated ${ }^{187} \mathrm{Os} /{ }^{188} \mathrm{Os}$ for this reservoir is much higher than the ratio for hydrothermal or average crustal Os. As a result of this large ratio, these 
sediments contribute a disproportionately large amount $(>50 \%)$ to the upper continental crustal rhenium and, to a lesser extent (5-10\%), surficial osmium inventories despite the very low abundance of these sediments in the upper continental crust. In fact, the estimated isotopic ratio limits their volumetric abundance to $<1 \%$ of the UCC.

In chapter 3, I examine two marine sediment cores that record the CIE at the PETM. I focus on determining whether these cores record a $\mathrm{Pb}$ isotopic signature consistent with an additional source of $\mathrm{Pb}$ from organic-rich sediments at the PETM. A change in the $\mathrm{Pb}$ isotopic composition is indicated, but it is inconsistent with organic-rich sediments being the $\mathrm{Pb}$ source. This finding does not invalidate the hypothesis that thermal alteration of sediments in the NAMP was the trigger for the PETM, as later chapters show that $\mathrm{Pb}$ is not mobilized to the overlying water during thermal alteration of organic-rich sediments. Additionally, $\mathrm{Pb}$ isotopes are measured using bulk sediment dissolution. Only a small portion (likely $<25 \%$ ) of the bulk sediment $\mathrm{Pb}$ is composed of $\mathrm{Pb}$ derived from a hydrogenous source, with the remaining $\mathrm{Pb}$ being detrital in origin. Because of this small fraction, any change in the hydrogenous signal may be masked by changes in the isotopic composition of the detrital fraction. Finally in this chapter, I examine the major and trace elemental composition of the sediments from DSDP Site 549. While several elements show interesting concentration variations with depth, none stood out as candidates to provide further evidence for the trigger mechanism for the PETM.

In chapter 4 , a potential terrestrial analog for the NAMP, a setting in northern New Mexico (Raton Basin) where dikes intrude the organic-rich Pierre Shale, is examined to determine the effects of thermal alteration on the mobility of organic carbon, lead, rhenium and osmium. Total organic carbon is strongly depleted close to the intrusive contact, and concentrations increase farther away from the magmatic contact. In contrast, Re and Os 
concentrations did not change over the sampled interval, which does not lend support to the hypothesis that the excursion to more radiogenic ${ }^{187} \mathrm{Os} /{ }^{188} \mathrm{Os}$ of seawater during the PETM was caused by release of radiogenic Os from organic-rich sediments in the NAMP. Lead, uranium, and thorium concentrations similarly did not change significantly.

Finally, in chapter 5, I examine a potential marine analog for the NAMP in the Guaymas Basin, in order to assess whether marine pore fluids help to mobilize elements such as osmium and lead during thermal alteration. In this sediment depth profile, carbon is released from sediments close to the magmatic contact. However, unlike at the terrestrial field site in the Raton Basin, Os was also mobilized during thermal alteration. Based on the relative concentrations of TOC and Os mobilized from organic-rich sediments in the Guaymas Basin, and reasonable assumptions of the ${ }^{187} \mathrm{Os} /{ }^{188} \mathrm{Os}$ of such sediment, the entire seawater Os isotope excursion at the PETM can be explained by release of Os from metamorphosed organic-rich sediments. Under this scenario, approximately $47 \%$ to $60 \%$ of the carbon released at the PETM may have been derived from thermal alteration of organic-rich sediments in the NAMP. Lead was not mobilized to seawater during contact metamorphism, indicating that the $\mathrm{Pb}$ isotope system is not viable as a test of the amount of carbon released by thermal alteration of the NAMP during the PETM.

\subsection{Implications and future work}

\subsubsection{Further exploration of thermal alteration at the PETM}

Additional lines of evidence could be explored to further constrain whether the PETM might have been caused by thermal alteration of organic-rich sediments from sill and dike intrusions into the NAMP, as proposed by Svensen et al. (2004). One potential avenue for future exploration is to examine the $\mathrm{Pb}$ concentrations and isotope ratios associated with the hydrogenous phases in marine sediments at the PETM. Lead released from organic-rich 
sediments in the North Atlantic magmatic province could potentially be released to overlying waters as dissolved $\mathrm{Pb}$. This hydrogenous phase would be associated with authigenic phases, such as Fe-Mn coatings on detrital grains. In chapter 3, I examined the lead isotopic composition of the bulk sediment. However, only a fraction of the lead in the bulk sediment is associated with hydrogenous host phases, the remaining being carried by detrital phases. This detrital lead signal may mask the small hydrogenous signal, making it difficult to determine the changes in oceanic $\mathrm{Pb}$ isotope compositions that were caused by $\mathrm{Pb}$ derived from organic-rich sediments. Future work on the $\mathrm{Pb}$ isotope composition of these authigenic phases, for instance by means of sequential leaching protocols aimed at dissolving Fe-Mn coatings, may reveal subtle changes in the $\mathrm{Pb}$ isotopic composition that are not apparent in the bulk analyses.

In chapter 4, I examine carbon loss in the Pierre Shale adjacent to the Eagle Rock dike intrusion. However, this site was not sampled far enough away from the intrusive contact to determine the full extent of carbon loss at this location. Resampling the Pierre Shale farther away from the dike contact would allow for a better determination of the total loss of carbon during terrestrial thermal alteration.

Existing records of the PETM osmium isotope excursion from Ravizza et al. (2001) do not display a high-resolution Os isotope record for the onset of the PETM. The onset of the CIE is much sharper than indicated by the carbon isotope record preserved in sediments from DSDP Site 549. Future work should be performed to generate a higher-resolution Os isotope record in a marine sediment core already having a higher-resolution record of the CIE at the PETM. Higher-resolution records would enable a close examination of the relationship between the carbon and osmium isotope excursions could provide evidence for the cause and effect relationship between the two isotope excursions. 
Additional major and trace element analysis on the Guaymas Basin sediments should be the focus of future work. An analysis of other elements released during thermal alteration could point to other inorganic isotope systems that could be examined to further constrain the amount and potential sources of carbon derived from thermal alteration of sediments in the NAMP during the PETM, or otherwise provide an indication of alternative trigger mechanisms for the CIE. Understanding the systematics of element mobility and release during thermal alteration could provide guidance for more targeted additional analyses of sediment cores spanning the PETM. Such analyses could also substantiate the claim that the observed changes in element concentrations $(\mathrm{C}, \mathrm{Os}, \mathrm{Pb})$ are not the result of primary differences in the composition of the sedimentary strata drilled at DSDP Site 477.

\subsubsection{Implications for other climatic events}

The PETM is not the only period in earth's history in which large-scale intrusions into a submarine rift valley occurred. Understanding the PETM may give insights into climatic variations at other periods of time, and vice versa. Examination of the relationship between the osmium isotope ratios and large-scale thermal alteration of organic-rich sediments may provide further insight into whether this is a common phenomenon, which would be helpful in determining whether the osmium isotope anomaly at the PETM was in fact caused by thermal alteration of organic-rich sediments. The Siberian Traps at the Permo-Triassic boundary and the Karoo Igneous Province at the Early-Middle Jurassic boundary are both Large Igneous Provinces which are associated with large negative carbon isotope excursion (Svensen et al., 2004; Wignall, 2001). Further examination of the osmium isotopic composition of marine sediments from these time periods, as well as the relationship to the carbon isotopic compositions, could provide 
insights into the impact of thermal alteration of organic-rich sediments on other periods in earth's history. 


\subsection{References}

Ravizza G., Norris, R.N., Blusztajn, J., Aubry, M.-P., 2001. An osmium isotope excursion associated with the late Paleocene thermal maximum: Evidence of intensified chemical weathering. Paleoceanography 16, 155-163.

Svensen, H., Planke, S., Melthe-Sørenssen, A., Jamtveit, B., Myklebust, R., Rasmussen Eidem, T., Rey, S.S., 2004. Release of methane from a volcanic basin as a mechanism for initial Eocene global warming. Nature 429, 542-545.

Wignall, P.B., 2001. Large igneous provinces and mass extinctions. Earth Science Reviews 53, $1-33$. 